\title{
Ernst \&Ernst
}

\section{Energy Management Manual}

\section{MASTER}

Prepared for the

Jicarilla Apache Tribe

Under Contract to the

U.S. Department of Energy

June 1979

$\mathrm{E} \& \mathrm{E}$ 


\section{DISCLAIMER}

This report was prepared as an account of work sponsored by an agency of the United States Government. Neither the United States Government nor any agency Thereof, nor any of their employees, makes any warranty, express or implied, or assumes any legal liability or responsibility for the accuracy, completeness, or usefulness of any information, apparatus, product, or process disclosed, or represents that its use would not infringe privately owned rights. Reference herein to any specific commercial product, process, or service by trade name, trademark, manufacturer, or otherwise does not necessarily constitute or imply its endorsement, recommendation, or favoring by the United States Government or any agency thereof. The views and opinions of authors expressed herein do not necessarily state or reflect those of the United States Government or any agency thereof. 


\section{DISCLAIMER}

Portions of this document may be illegible in electronic image products. Images are produced from the best available original document. 


\section{MasteR}

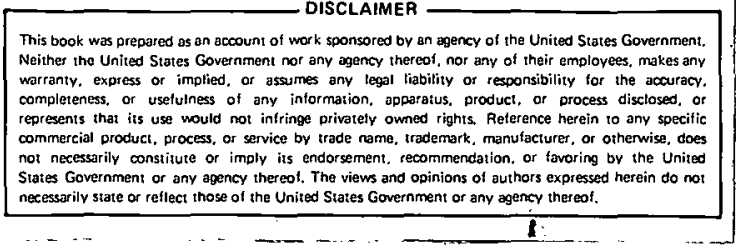

\section{ENERGY MANAGEMENT MANUAL}

PREPARED FOR

THE JICARILLA APACHE TRIBE

Under Contract to the

U.S. DEPARTMENT OF ENERGY

This report was prepared by Ernst \& Ernst under contract (EC-76-C-01-8659) for the U.S. Department of Energy, and does not necessarily state or reflect the views, opinions, or policies of the Department of Energy or the Federal government.

$$
A C 01-76 P R 50162
$$

ERNST \& ERNST

JUNE 1979 
TABLE OF CONTENTS

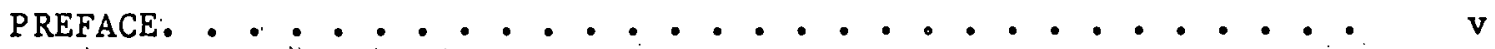

I. CONSTRAINTS ON TRIBAL REGULATION OF ENERGY DEVELOPME'NT . . . . I I-1

Background . . . . . . . . . . . . . . . . I-1

Current Energy Management Issues . . . . . . . . . II-2

Entering into Contracts. . . . . . . . ....... I-3

Monitoring and Enforcing Operating Standards........ . I-4

Taxing Severance of $0 i 1$ and Gas from the Land... . . . . I-9

II. ENERGY MANAGEMENT NEEDS. . . . . . . . . . . . . . II-1

Background . . . . . . . . . . . . . . . . II-I

Relationship Between Federal Agencies and the

Jicarilla Apache Tribe . . . . . . . . . . . . . II-3

USGS Southern Rocky Mountain Area Office . . . . . . 11-4

USGS District office............... II-4

BIA Jicarilla Agency . . . . . . . . . . . 11-5

Opportunities for Improving Federal-

Tribe Cooperation. . . . . . . . . . II-6

Identification of Energy Managenent Problems . . . . . . . II-6

Planning . . . . . . . . . . . . . . . . II-7

Making Development Decisions . . . ........ II-10

Monitoring and Enforcement ............... II-1I

Recommended Management Activities to Address Protlems. . . . . II-15

Summary of Recommended Energy Activities . . . . . . II-15

Planning . . . . . . . . . . . . . . . . . II-16

Developwent Decisions. . . . . . . . . . . . . II-17

Monitoring and Enforcements. . . . . . . . . . . . II-19

General Management Activities. . . . . . . . . . II-22

Skill Requirements .................. II-22 
III. ENERGY MANAGEMENT PLAN FOR THE JICARILLA APACHE TRIBE. • • • . III-1 Introduction ..................... III-2

A. Goals and objectives ............... . III-4

B. Energy Management Strategy . . . . . . . . . . III-9

C. Recommended Energy Management Activities . . . . . . III-11

Short-Term Activities ............... III-18

Intermediate Activities. . . . . . . . . . . . III-58

Long-Term Activities . . . . . . . . . . . . . III-68

D. Implementation Plan. . . . . . . . . . . . . III-71

APPENDIX A: LEGAL ANALYSIS OF OIL AND GAS DEVELOPMENT ON THE

LAND OF. THE .JICARILLA APACHE TRIBE

Part I: Federal Constraints--Statutory and Regulatory . . . . A-I-1

Part II: State Jurisdiction Over Non-P.L. 280

Intrareservation Matters. ..............A-II-1

Part III: Jicarilla Tribal Governmental Authority Over

Mineral Operations. . . . . . . . . . . . . A-III-1 


\section{LIST OF EXHIBITS}

Exhibit No.

Title

Page

Tribal Profile. . . . . . . . . . . . .

vi

$I-1$

Tasks Performed for Oil and Natural Gas

Development. . . . . . . . . . . . I-12

I I-1

Activity Requirements by Skill Category . . . . . II-23

I I-2

Probable Tribal Staff Activity Requirements . . .. II-24

II-3

Suggested Activities to be Performed by Consultants and Associated Tribal Responsibilities . . . . . . . . . . II-25

III-1

Energy Management. Model by Type of Development Arrangement............ III-10

I I -2

Jicarilla Apache Tribe Organizational Structure and Possible Placement of Energy Management Units. . .......... III-12

Proposed Energy Management Activities for the Jicarilla Apache Tribe....... III-14

Development of Tribal Information Processing System. . . . . . . . . . . III-24

I I I -5

Possible Environmental Assessment Forms . . . . III-45

I I I-6

Possible Procedure for Environmental Assessments. . . . . . . . . . . III-47

III-7 Possible Solicitation for 0il \& Gas Advisor. . . . . . . . . . . III-57 


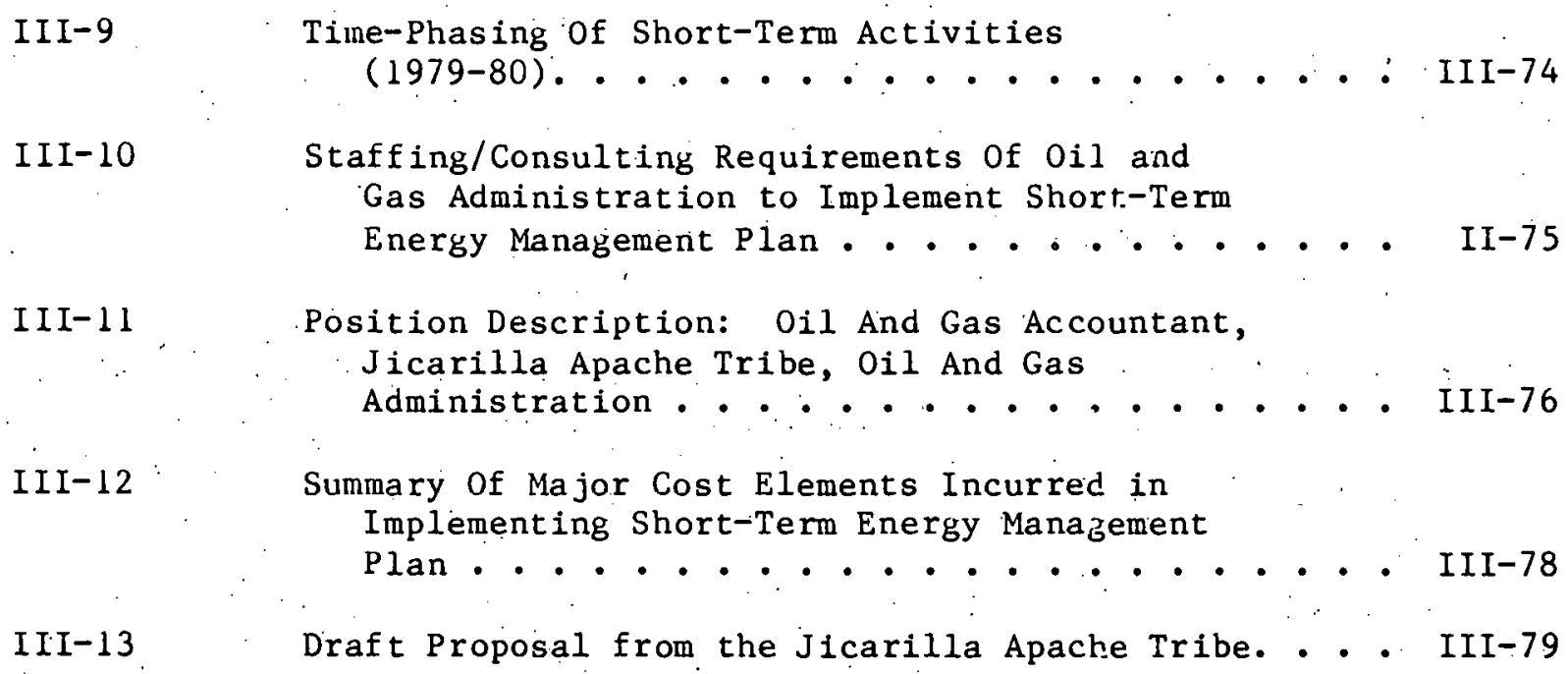


PREFACE

This report is designed as an energy management manual for the use of the Jicarilla Apache Tribe. It is divided into three parts: (1) a discussion of constraints on Tribal regulation of energy development, (2) delineation of energy management needs of the Tribe, and (3) an energy management plan for use by Tribal leaders in developing and managing the Tribe's energy resource. Exhibit i provides a profile of the Jicarilla Apache Tribe and its energy resources. 
The following Information was compiled from data obtained by Ernst \& Ernst under contract with the Federal Energy Administration to assess energy resource development on reservations of members of the Council of Energy Resource Tribes, in 1974.

TRIBE Jicarilla Apache

RESERVATION Jicarilla

LOCATION (COUNTIES) Rio Arriba and Sandoval (New Mexico)

I. GENERAL INFORMATION

1. ACREAGE 742,315

2. SURFACE OWNERSHIP Tribal

3. PROBLEMS REGARDING MINERALS OWNERSHIP None

4. POPULATION 1,928 (BIA 3/72)

5.: KEY ECONOMIC ACTIVITIES 011 and gas production, some tribal commercial businesses

11. TRIBAL GOVERNMENT

1. GOVERNING BODY Tribal Council

2. NUMBER OF MEMBERS President, Vice President ard eight members

3. FREQUENCY OF ELECTIONS 4 year terms (staggered among members)

4. QUALIFIED FOR PL 93-638. FUNDS? Yes

5. CURRENT MINERALS RELATED PROGRAMS $0 i 1$ and Gas Administration fust established to implement operating agreements; oil and gas given emphasis in economic development planning; Natural Resources Committee develons nolicies.

6. TYPES OF MINERALS PROGRAMS THAT MAY BE NEEDED Planning: Water quality and siting of oil and gas roads, pipelines, etc.; Decisions: review of tract nominations and contractual arrangements; Controls: account-. ing, auditing, inspections, and other functions under the operating agreements and pursuant to litigation.

7. GENERAL WILLINGNESS TO PARTICIPATE IN STUDY Very cooperative 


\section{MINERALS RESOURCES INFORMATION}

1. MAJOR DEPOSITS OR FIELDS ON OR NEAR THE RESERVATION

- OIL AND GAS San Juan Basin; Blanco, South Blanco and Basin fields

- COAL San Juan Basin (Pagosa Springs area; Montero Mesaverde field)

- URANIUM Possible occurrence

- OIL SHALE No known occurrence

- GEOTHERMAL Possible occurrence

2. QUANTITY AND QUALITY OF RESERVES

- OIL AND GAS All data confidential

- cOAL No measured reserves

- URANIUM No measured reserves

- OIL SHALE No known occurrence

- GEOTHERMAL No measured rèserves

3. MINERALS PRODUCTION

- OlL "B" (100,000 - 1 million Bbls $)$

- GAS "A" (10 - 40 BCf $)$

- cOAL None

- URANIUM None

- oIl Shale None

- GEOTHERMAL None

4. ENERGY TRANSPORTATION AND CONVERSION FACILITIES 011 and gas pipelines and processing facilities; proposed amonia production from gas byproducts

5. MAJOR LESSEES OR OPERATORS E1 Paso, Palmer, Southern Union, Odessa Natural, numerous others

6. TRENDS IN CONTRACTING ACTIVITY Tribal policy to discontinue use of standard leases and to enter into operating agreements (two agreements are in effect); extensive litigation to cancel leases not producing in paying quantities, or which were issued without EISs. 
I. CONSTRAINTS ON TRIBAL REGULATION OF ENERGY DEVELOPMENT

BACKGROUND

The Jicarilla Apache Tribe is organized in accordance with the Indian Reorganization Act of 1934, entitling it to enact and enforce ordinances and to enter into contracts.1/ The Tribe has been Involved in oll and natural gas development for several years. There are 279 active leases with total annual production somewhere in the range of $100,000-1,000,000$ barrels of ofl and 10-40 thousand cublc feet of gas.2/ $\mathrm{A}$ total of 109 of the leases in force since 1958 have had a 12-1/2 percent royalty. Since the revision of the U.S. Geological Survey (USGS) leasing regulations, 170 leases at $16-2 / 3$ percent have been signed. All of these leases are standard form 5-157 leases, that is, crawn up for the Tribe by the U.S. Department of the Interior (DOI), and used unfformly in a variety of circumstances and (Tribal leaders feel) not always to the best advantage of the Tribe. Besides leases, three jolnt ventures, or net-profit agreements, are in effect.

When hostilities between Indians and the U.S. government ceased in the nineteenth century, tribes gave up certain sovereign rights, and in turn the U.S. government agreed to act in protection of the tribes' interests and their limited soverefgnty. As part of this trust 
responsibility, the DOI is required by statutory and regulatory law to oversee the leasing and development of oil and gas lands held by Indians. Also included in this responsibility is the monitoring and enforcement of performance standards for safety, engineering, environmental protection, and financial reporting. However, the USGS and the Bureau of Indian Affairs (BIA) trust responsibilities have been deficlent in most respects-inspections, enforcement of Federal regulations, and accounting functions--as discussed in Volume II, Section III of the Planning Manual. As a result of past difficulties with oil and gas leases, the Tribe intends to manage new development through a Model III approach (developing management functions in-house). $\underline{3}$ / The cornerstone of this approach is the use of joint ventures for all new contracts along with sponsorship of Tribal development. With respect to existing development, the Tribe's strategy has paralleled the Model II approach, attempting to maximize the extent to which the USGS and BIA cooperate with the Tribe in adminfstering trust responsibilities.4/ The Tribe has also initiated several lawsults agalnst lessees over noncompliance with lease terms.

\section{CURRENT ENERGY MANAGEMENT ISSUES}

In each of the following areas, the Tribe may encounter legally oriented problems as it moves toward more active minerals management:

- Entering into contracts

- Monitoring and enforcing performance standards

- Taxing severance of the ofl and gas from the 1and.

Each of these areas is discussed in more detall below. 


\section{Entering Into Contracts}

Under existing and proposed USGS regulations, the Tribe may enter

into any contractual agreement it can negotiate in its best interest. $\underline{5}$ / The Secretary of the Interior is required by Federal statute, regulation, and Tribal charter to approve all oil and gas leases.6/ Other forms of agreements, such as net profits contracts, regardless of duration, should receive Secretarial approval as a procedural safeguard.ㄱ/

Under the proposed regulations (25 C.F.R. $\$ 182$ ), the Secretary's decision to approve a contract is based on the BIA's written findings on the contract's desirability. These findings would incorporate the USGS Supervisor's evaluation of advantages and disadvantages of the contracting method. $8 /$ These regulations are not in final form and may be changed before their final issuance. The Tribe should continue to operate under the old regulations, while monitoring the status of the proposed regulations.

Previously, when the Tribe used standard lease forms, the approval process was essentially pro forma. The DOI operated on the assumption that the leases it had formulated for the Indians would adequately protect the Tribe. As a consequence, the approval process was relatively prompt. Now that the Tribe is disinclined to use the lease-royalty approach and favors the joint venture contract, the USGS/BIA review of the proposed contracts could become more time consuming if contracts differ significantly. To simplify contracting, the Tribe has recently developed its own standardized joint venture contract. If this is used uniformly, it should speed up Secretarial approval. Because BIA and USGS will be reviewing similar contract provisions time after time, the process will probably become more efficient and less time consuming. To 
the ofl and gas developer, a standard contract (and timely Secretarial approval) will probably be advantageous since it will mean realizing revenue at an earlier date.

In addition to the use of standard form contracts to speed up Secretarial approval, the Tribe would probably find i.t desirable to negotiate for certain contract provisions including environmental performance standards, Tribal taxation, and recognition of Tribal legal jurisdiction. These items are discussed in more detall below.

A further legal consequence of the Tribe's use of a joint venture approach involves auditing the ofl and gas operation. Under the proposed Federal regulations, the USGS Supervisor is clearly required to maintain accounts for leases, or other agreements granted by the Tribe, Involving compensation to the Tribal lessor or transferor based on gross production. This is not the case for contracts on net profits or profit sharing. $9 /$ Under the current regulations, the Supervisor's duty is not entirely clear with regard to the latter type of agreements.10/ Therefore, by entering Into financlally advantageous joint venture contracts, the Tribe may also be assuming the responsibility to audit the oil and gas operation for its own protection. This may involve detection of revenue misrepresentation, embezzlement, and other forms of financial mismanagement.

Monitoring and Enforcing Operating Standards:

General Problems. In theory, the law requires the DOI to monttor oll and gas operations on behalf of the Indians and to enforce applicable Federal laws.11/ The USGS Supervisor also possesses the power to approve or deny the designated operator, to grant the operator relief from regulations, and to approve or deny original plans and variations for such 
operating features as well spacing, procedures for taking gas in kind, location near inhabited structures, etc.12/ The USGS is also required to process operator reports on fires; accidents, use of explosives, well operation, and production. Under the current regulations, responsibility for approval of tract surrender,13/ enforcement of the agreement or lease, $14 /$ and restrictions on operations $15 /$ rests primarily with the Secretary of the Interior or his delegated representative.

In practice, the USGS and BIA are able to fulfill their administrative requirements adequately--processing the reports and approving operating plans (although the magnitude of paperwork sometimes creates problems in obtaining access to information). However; because of understaffing problems, the USGS has historically been unable to monitor operations and enforce all applicable Federal regulations to the extent needed. The applicable regulations are shown in Exhibit $I-1, \mathrm{pp} . \mathrm{I}-12$ thru I-16. The USGS Conservation Division only completes 50 percent of the needed inspections of oil and gas operations.16/. Ir the USGS region covering the Jicarilla Apache reservation, understafing is not as severe, so this percentage may actually be higher. Still, in the opinton of Tribal leaders, inspections are neither frequent enough nor as intensive as they could be.

The Tribe has two broad options for enforcing: oil and gas operating performance standards:

(1) The Tribe can use its staff to monftor operations in accordance with existing Federal regulations and then present Tribal results to the USGS or other Federal agencies for enforcement

(2) The Tribe may enforce existing Federal regulattons itself or, if existing Federal regulations are deemed inadequate, the Tribe can pass its own laws and attempt to enforce them.

(See Maxfield's discussion of Tribal regulation in Appendix A.) 
The current regulations limit the Tribe's right to inspect oil and gas operations.17/ Therefore, a waiver of the regulations and a formal memorandum of understanding between the DOI and the Tribe would be needed to permit the Tribe to perform inspections on behalf of the DOI.18/ Beyond regulatory limits, the major restrictions are lack of staff training and the logistical difficulty of acting as an "ad-hoc" field agent for the relevant agencies.

The second approach (a Model III approach) entails passage and enforcement of Tribal laws that are at least as restrictive as Federal or State regulations. In this situation, the oil and gas firm would probably challenge the Tribe's judisdictional authority. In the case of leases, the Tribe would have to fight the challenge in court. For joint ventures, the Tribe can avoid such a legal challenge to its ability to regulate oil and gas operators on the reservation through provisions in the joint venture contract. $19 /$

First, the Tribe can negotiate for a clause in the joint venture agreeinent whereby the firm agrees to abide by all Tribal regulations. By arreeing to this provision the firm would explicitly agree to recognize the Tribe's jurisdiction. This would serve to make the firm aware of the Tribe's priorities. Also, the firm would not be able to challenge the Tribe's right to regulate. If the Tribe is to monftor, enforce, and prosecute under its regulations, the development of better Tribal legal and juridical capabilities may be necessary. Of course if a firm is unwlling to agree to such a broad agreement in the contract, the Tribe may want to take another approach. 
The second approach is to include specific clauses in the contract by which the firm agrees on a case-by-case basis to meet specific financial reporting, environmental, and/or safety standards proposed by the Tribe. Also, this approach is more flexible for contract bargaining than requiring compliance with uniformly strict regulations.

\section{Specific Concerns and Possible Approaches. There are currently} three major areas of monitoring and enforcement being dealt with by the Tribe: (1) environmental regulation, (2) land use and siting decisions, (3) accounting for oil and gas operations. In each of these areas the Tribe is using a flexible strategy with varying mixes of the two management models--Tribal regulation and better Federal trust administration. First, as a Tribe with oil and gas, the Jicarilla Apache Tribe is less likely to experience pollution than a tribe with hard minerals. Nonetheless, groundwater pollution from oil well steam injection, air pollution from fires, or surface water contamination from pipeline leaks could occur in violation of Federal environmental quality regulations. Several Tribal leaders involved with oil and gas development would prefer that the Tribal government have at least partial responsibility for enforcing Federal environmental regulations on the reservation.

However, the legality of the Jicarilla's enforcing Federal standards depends in large part on the outcome of a jurisdictional dispute between the State government of New Mexico and the Navajo Tribe. The Navajo has tried to enforce strict environmental regulations on its reservation by Imposing a pollution fee for power plant sulfur emissions. The State of New Mexico says the fee is in conflict with the State's air quality plan.20/ The case has not yet been decided. 
In part because of this case, a high-level EPA policy group is considering whether to enable tribes to be formally designated as agents for enforcement of EPA regulations on the reservation. If the recommendation favors tribal enforcement, then the Jicarilla, Laguna, Navajo and other tribes desiring to enforce Federal regulations could apply for designation by EPA as the responsible agency. The designated tribes would be able to enforce these regulations for oil and gas operations on the reservation. If the new policy does not support the concept of tribal enforcement, then the Jicarilla Apache Tribe would probably need to fall back on the use of contractually established regulation. However, this would only. apply to new or renewed contracts.

The second area of concern is the increasing land area taken up by oil and gas rights-of-way and the resulting fragmentation of Indian land use patterns. The operating company is required to submit a development plan to the BIA showing roads and rights-of-way; the BIA approves each application individually. The result of this piecemeal approach is that the cumulative effects of rights-of-way and roads are not fully evaluated. The Tribe has responded to this land use problem by passing in 1976 an environmental ordinance requiring developers to submit to the Tribe an analysis of property development impacts. With these analyses, the Tribe can keep better records on specific land parcels and can better apply efficient land use techniques, e.g., joint rights-of-way, limited access roads; etc. The Tribe would like to take the lead on this issue and, by example, influence the BIA and USGS to take a more comprehensive approach to land use impacts of oil and gas development.

The third major problem concern of the Jicarilla Apache Tribe is how to change lease accounting responsibllities to the Tribe's advantage. 
Currently, payments are routed through the USGS for all leases. The USGS requires a month to process payments before they are transmitted to the Tribe. Because of this delay, the Tribe in 1976 passed an ordinance imposing a late payments fee on the companies. One round of fees was billed and many companies paid. However, some comparies refused to pay the fee. Most of the companies have since arranged to prepay the monthly fee to USGS based on estimated production. Adjustments in the next month's payment are made to correct for errors.

Another option for the Tribe is to have revenues from the operator deposited directly to Tribal accounts. The Jicarilla Apache Tribe would need to coordinate payments with the USGS in depository banks. This would give the Tribe administrative control over receipt of direct payments and ensure prompt payments due the Tribe.20a/

\section{Taxing Severance of nil and Gas from the Land}

The Tribe has imposed a severance tax to build up a permanent fund for long term investment needs and thus to provide revenue after oil and gas operations cease. Because substantial revenue is at stake and some of these leases are long-term, the successful application of the tax is important to the Tribe. However, oil and gas firms are confronted with severance taxes 1mposed both by the Tribe and by the State of New.Mexico, 1.e., a double tax. Therefore, these firms have objected to the Jicarilla tax, which was established after the State tax.

In Merrion and Bayless et al. vs. Jicarilla Apache Tribe et al., the Federal District Court for New Mexico ruled that mineral production on the reservation may be taxed by the State and that the Tribe's tax was not valid.21/ The judge's ruling rested on three arguments: 
- The double tax represents an "undue burden on interstate commerce.".

- States have the congressionally expressed right to tax mineral production from reservation lands.

- The Indian Reorganization Act does not explicitly grant IRA tribes the right to tax non-Indians.

The Tribe has appealed the decision to the Tenth Circuit Court of Appeals. Several legal issues applicable to the appeal are discussed by

Maxfield:

- Within certain limits, States have the right to tax non-Indian income and receipts on the reservation. $22 /$ However, since the Jicarilla ownership and control of the land is federally recognized, as is the Tribe's governmental authority, the Tribe may also impose the tax. 23 /

- The notion that Indians do not have the right to tax non-Indians on the reservation is inconsistent with many court rulings supporting Tribal sovereignty. $24 /$

In Maxfield's view; the Federal District Court of New Mexico in Merrion is

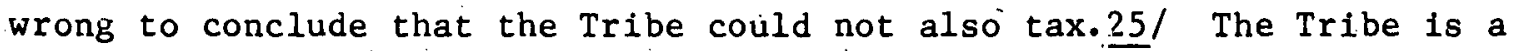
soverelgn entity with the right to tax. In the Crow Tribe of Indians vs. the State of Montana, Montana's severance tax on coal production on Indian lands is being challenged on similàr grounds.

The appeal of the case by Tribal lawyers argues that:

- States are given explicit taxation rights under the 1927 Leasing Act [25 U.S.C. 398(C)]. However, the leases on the Jicarilla Apache Reservation were let under the provisions of the 1938 Act [25 U.S.C. 3.96], which does not give States the explicit right to tax mineral production on Indian lands. The 1938 Act repealed all provisions of earlier leasing acts inconsistent with the 1938 Act. 
- The 1934 Indian Reorganization Act does not explicitly state that tribes have the right to tax non-Indians on the reservations. However, in its enumeration of sovereign rights limited or taken away from the tribes, taxation is not listed. Therefore, the sovereign right to tax is unaffected by the 1934 Act and remains the prerogative of the Tribe.

If the Appeals Court rules in favor of the Tribe, then in order to be relieved of the double tax the companies may challenge the State of New Mexico severance tax. If the Tribe loses, the argumients used by the District judge would seem to preclude any taxation of non-Indians by Indians. Beyond the severance tax, other taxes and fees also are affected by legal constraints. These are discussed in detail by Maxfield in Appendix A. 
EXHIBIT I-1

TASKS PERFORMED FOR OIL AND NATURAL GAS DEVELOPMENT

\begin{tabular}{|c|c|c|c|c|c|c|}
\hline \multirow[b]{2}{*}{$\begin{array}{l}\text { Program } \\
\text { Area }\end{array}$} & \multirow{2}{*}{\multicolumn{2}{|c|}{ 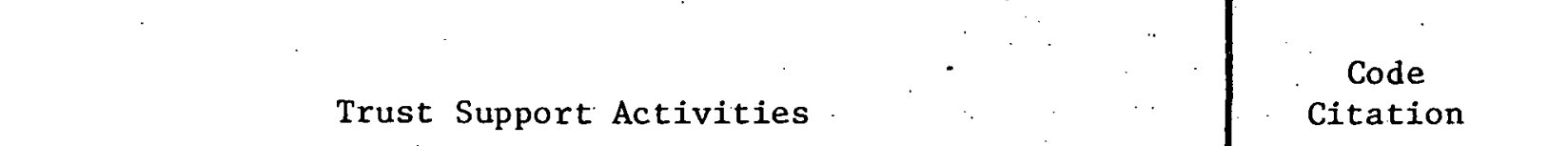 }} & \multicolumn{4}{|c|}{ Responsible Agent } \\
\hline & & & Tribe & $\begin{array}{l}\text { DOI } \\
\text { Sec. }\end{array}$ & $\begin{array}{c}\text { USGS. } \\
\text { Super. }\end{array}$ & $\mathrm{BI} A$ \\
\hline 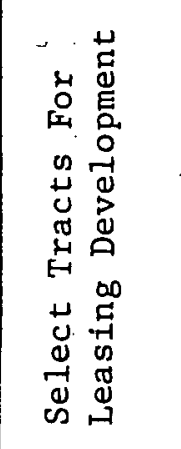 & $\begin{array}{l}\text { Process all geologic and geophysical permits } \\
\text { Approve all geologic and geophysical work plans } \\
\text { Process all tract nominations } \\
\text { Advise tribes of nominations by industry and option to not } \\
\text { develop } \\
\text { Provide any technical advice requested }\end{array}$ & $\begin{array}{l}25 \text { CFR } 182.9 \\
25 \text { CFR } 182.9 \\
25 \text { CFR } 182.12 \\
25 \text { CFR } 182.13(\mathrm{a}) \\
25 \text { CFR } 182.11(\mathrm{~b})\end{array}$ & $\mathrm{X}$ & $\begin{array}{l}\mathrm{X} \\
\mathrm{X}\end{array}$ & $\mathrm{X}$ & $x$ \\
\hline 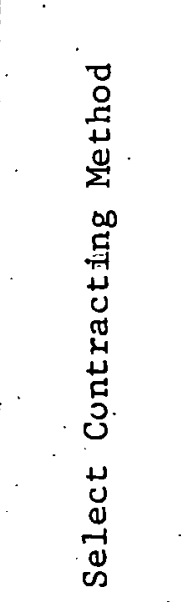 & $\begin{array}{l}\text { Tribes organized under the } 1934 \text { IRA may opt to ase competi- } \\
\text { tive bidding, negotiations, or other means of contracting } \\
\text { Prepare written findings for the DOI secretary if tribe uses } \\
\text { method other than competitive bidding } \\
\text { Determine any special terms of the contract prior to adver- } \\
\text { tising of bids } \\
\text { Advise BIA Sunerintendert on advantages/disadvartages of } \\
\text { alternative contracting methods } \\
\text { Provide tribe with any technical advice requested on con- } \\
\text { tractual alternatives }\end{array}$ & $\begin{array}{l}25 \text { CFR } 182.12(a) \\
25 \text { CFR } 182.12(d) \\
25 \text { CFR } 182.12(\mathrm{c}) \\
25 \text { CFR } 182.12 \\
25 \text { CFR } 182.4\end{array}$ & $x$ & $\mathrm{X}$ & $\begin{array}{l}\mathrm{X} \\
\mathrm{x}\end{array}$ & 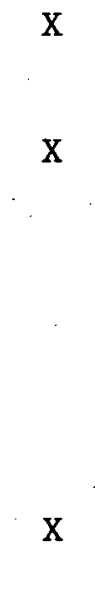 \\
\hline 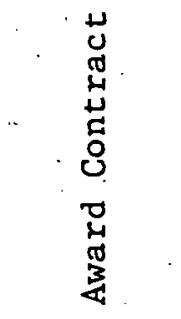 & $\begin{array}{l}\text { For competitive bidding } \\
\quad \text { - Advertise for sealed bids } \\
\text { - Hold lease sale }\end{array}$ & 25 CFR 182.12(c) & & $\mathrm{X}$ & & \\
\hline
\end{tabular}


EXHIBIT I-1 (Cont.)

\begin{tabular}{|c|c|c|c|c|c|c|}
\hline $\begin{array}{l}\text { Program } \\
\text { Area }\end{array}$ & Trust Support Activities & $\begin{array}{l}\text { Code } \\
\text { Citation }\end{array}$ & Tribe & $\begin{array}{l}\text { DOI } \\
\text { Sec. }\end{array}$ & $\begin{array}{l}\text { USGS } \\
\text { Super. }\end{array}$ & BIA \\
\hline 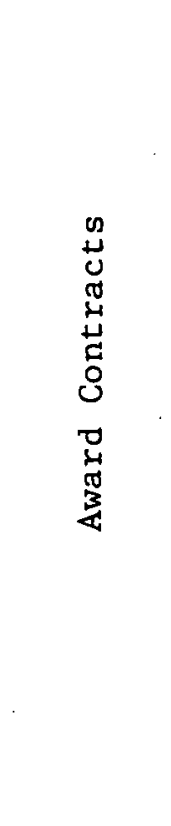 & $\begin{array}{l}\text { Determine that all contracts } \\
\text { - provide fair and reasonable renumeration } \\
\text { - environmental and cultural costs do not outweigh } \\
\text { - conefits } \\
\text { Determine rentals, royalties, if other than minimum rates } \\
\text { Determine bases for measuring production and value of the } \\
\text { products for royalty calculations } \\
\text { Determine manner and frequency of payments } \\
\text { Require surety bond, if deemed appropriate } \\
\text { Accept/reject bids on contract terms } \\
\text { Process bid fees, file contract forms, etc. }\end{array}$ & $\begin{array}{l}25 \text { CFR } 182.13 \\
25 \text { CFR } 182.16 \\
25 \text { CFR } 182.16(\mathrm{~d}) \\
25 \text { CFR } 182.17(\mathrm{a}) \\
25 \text { CFR } 182.15 \\
25 \text { CFR } 182.12 \\
25 \text { CFR } 182.12\end{array}$ & $\begin{array}{l}X \\
X\end{array}$ & $\begin{array}{l}X \\
X \\
X\end{array}$ & . & $\mathrm{x}$ \\
\hline 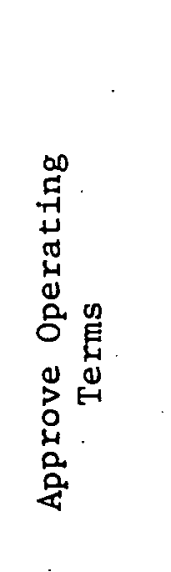 & $\begin{array}{l}\text { Approve all assignments and transfers } \\
\quad \text { - if entire interest } \\
\text { - if only one subdivision of contract or horizon, etc. } \\
\text { Process all assignments and transfers } \\
\text { Approve/deny designated operator } \\
\text { Approve, recognize, require cooperative and unit agreements } \\
\text { - process all applications and documents } \\
\text { - file copy of agreements }\end{array}$ & $\begin{array}{l}25 \text { CFR } 182.19 \\
25 \text { CFR } 221.19 \\
25 \text { CFR } 182.21\end{array}$ & $\begin{array}{l}X \\
X \\
X\end{array}$ & $\begin{array}{l}X \\
X \\
X\end{array}$ & $\begin{array}{l}\mathrm{X} \\
\mathrm{X}\end{array}$ & $\mathrm{x}$ \\
\hline
\end{tabular}


EXHIBIT I-1 (Cont.)

\begin{tabular}{|c|c|c|c|c|c|c|}
\hline $\begin{array}{c}\text { Program } \\
\text { Area }\end{array}$ & Trust Support Activities & $\begin{array}{l}\text { Code } \\
\text { Citation }\end{array}$ & Tribe & $\begin{array}{l}\text { DOI } \\
\text { Sec. }\end{array}$ & $\begin{array}{l}\text { USGS } \\
\text { Super. }\end{array}$ & BIA \\
\hline 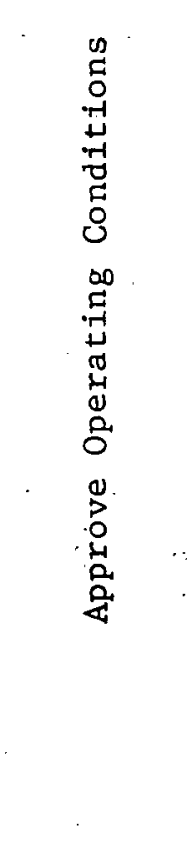 & $\begin{array}{l}\text { Approve contracts for storage facilities } \\
\quad \text { - process all applications and documents } \\
\text { - file copies of documents } \\
\text { Determine appropriate production flow (e.g., gas-oil ratio; } \\
\text { maximum efficient rate (mer) of production } \\
\text { Approve well-spacing and well-casing plans } \\
\text { Approve procedures for taking gas in-kind } \\
\text { Determine what samples are required regarding reservoir } \\
\text { management } \\
\text { Determine form and manner of submitting drilling reports, } \\
\text { division orders, run tickets, and sales agreement } \\
\text { Determine adequate indemnity bond }\end{array}$ & $\begin{array}{l}25 \text { CFR } 182.22 \\
30 \text { CFR } 221.33 \\
30 \text { CFR } 221.10 \\
30 \text { CFR } 221.11 \\
30 \text { CFR } 182.16 \\
30 \text { CFR } 221.40 \\
30 \text { CFR } 221.23 \\
30 \text { CFR } 221.13\end{array}$ & $\mathrm{X}$ & $\begin{array}{l}\mathrm{X} \\
\mathrm{X}\end{array}$ & $\mathrm{X}$ & $\mathrm{X}$ \\
\hline 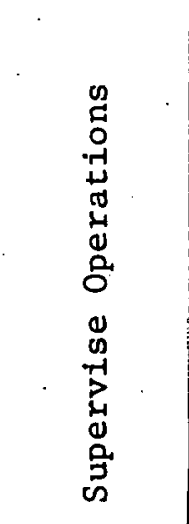 & $\begin{array}{l}\text { Prepare written consents for variations from well-location } \\
\text { restrictions } \\
\text { Prepare written consents for locating wells within } 200 \text { feet } \\
\text { of a home or barn } \\
\text { Prepare written consents for variances from well identifica- } \\
\text { tion requirements } \\
\text { Stipulate precautions for high-pressure areas }\end{array}$ & $\begin{array}{l}30 \text { CFR } 221.20 \\
30 \text { CFR } 221.20 \\
30 \text { CFR } 221.22 \\
30 \text { CFR } 221.24\end{array}$ & & & $\begin{array}{l}\mathrm{X} \\
\mathrm{X} \\
\mathrm{X}\end{array}$ & $\mathrm{X}$ \\
\hline
\end{tabular}


EXHIBIT I-1 (Cont.)

\begin{tabular}{|c|c|c|c|c|c|c|c|}
\hline \multirow[b]{2}{*}{$\begin{array}{c}\text { Program } \\
\text { Area }\end{array}$} & \multirow[b]{2}{*}{ Trust Support Activities } & \multirow{2}{*}{\multicolumn{2}{|c|}{$\begin{array}{c}\text { Code } \\
\text { Citation }\end{array}$}} & \multicolumn{4}{|c|}{ Responsible Agent } \\
\hline & & & & Tribe & $\begin{array}{l}\text { DOI } \\
\text { Sec. }\end{array}$ & $\begin{array}{l}\text { USGS } \\
\text { Super. }\end{array}$ & BIA \\
\hline 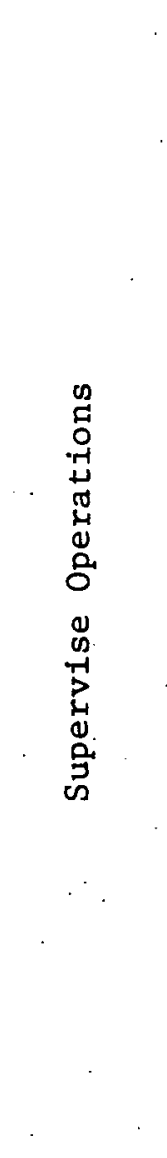 & $\begin{array}{l}\text { Approve procedures to minimize emulsion/dehydration } \\
\text { Approve any variations from vertical drilling } \\
\text { Prepare reports and recommendations on conditions and mea- } \\
\text { sures to be taken to maximize efficient recovery } \\
\text { Process requests for relief from regulations } \\
\text { Determine suitable plugging techniques } \\
\text { Approve/deny abandonments, suspensions } \\
\text { Approve resumption of production or operations } \\
\text { Process reports on fires and accidents } \\
\text { Process "sundry" reports on operations (e.g., intention to } \\
\text { drill, redrilling, using explosives, etc.) } \\
\text { Process reports on well logs and well history } \\
\text { Process monthly reports on operations, production } \\
\text { Process daily reports on gas meter results }\end{array}$ & 30 & $\begin{array}{l}\text { CFR 221.31 } \\
\text { CFR 221.27 } \\
\text { CFR 221.6 } \\
\text { CFR 221.39 } \\
\text { CFR 221.21 } \\
\text { CFR } 182.20(\mathrm{~b}) \\
\text { CFR 221.34 } \\
\text { CFR 221.15 } \\
\text { CFR 221.36 } \\
\text { CFR 221.59 } \\
\text { CFR 221.60 } \\
\text { CFR 221.61 } \\
\text { CFR 221.62 }\end{array}$ & $\mathrm{X}$ & $\mathrm{x}$ & $\begin{array}{l}\mathrm{X} \\
\mathrm{X} \\
\mathrm{X} \\
\mathrm{X} \\
\mathrm{X} \\
\mathrm{X}\end{array}$ & \\
\hline 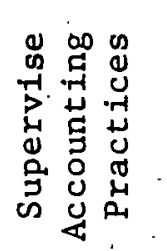 & $\begin{array}{l}\text { Maintain lease accounts (but not accounts under other contrac- } \\
\text { tual arrangements) } \\
\text { Process all payments }\end{array}$ & 30 & $\begin{array}{l}\text { CFR } 221.12 \\
\text { CFR } 221.40\end{array}$ & & & $\mathrm{X}$ & \\
\hline
\end{tabular}




\begin{tabular}{|c|c|c|c|c|c|c|}
\hline \multirow[b]{2}{*}{$\begin{array}{c}\text { Program } \\
\text { Area }\end{array}$} & \multirow[b]{2}{*}{ Trust Support Activities } & \multirow[b]{2}{*}{$\begin{array}{c}\text { Code } \\
\text { Citation }\end{array}$} & \multicolumn{4}{|c|}{ Responsible Agent } \\
\hline & & & Tribe & $\begin{array}{l}\text { DOI } \\
\text { Sec. }\end{array}$ & $\begin{array}{c}\text { USGS } \\
\text { Super. }\end{array}$ & BIA \\
\hline 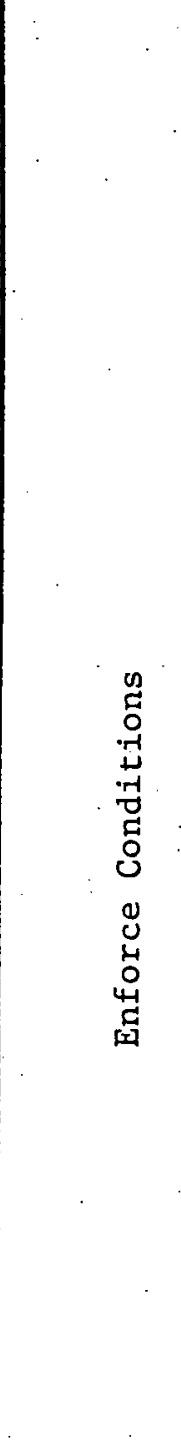 & $\begin{array}{l}\text { Compile and maintain records of production } \\
\text { Compile and maintain records of royalties accrued } \\
\text { Compile and maintain records of lost or wasted production } \\
\text { Approve/review royalty computations } \\
\text { Render monthly reports to lessors, agents on production, } \\
\text { royalty, drainage, and loss } \\
\text { Perform on-site inspections of operations } \\
\text { Review operator reports, accounts; and books } \\
\text { Prepare and serve noties of noncompliance } \\
\text { Assess and levy fines for liquidated damages } \\
\text { Require any correctiou of negative/adverse conditions } \\
\text { Authorize shut-down or cancellation of operations } \\
\text { Process all payments for damages to. Indiar property } \\
\text { Investigate all claims by Indian owner that operator is in } \\
\text { noncompliance }\end{array}$ & $\begin{array}{l}30 \text { CFR } 221.12 \\
30 \text { CFR } 221.12 \\
30 \text { CFR } 221.12 \\
30 \text { CFR } 221.43 \\
30 \text { CFR } 221.63 \\
30 \text { CFR } 221.5 \\
30 \text { CFR } 182.18 \\
30 \text { CFR } 182.23(\mathrm{~b}) \\
30 \mathrm{CFR} 221.54 \\
30 \text { CFR } 221.9 \\
30 . \mathrm{CFR} 221.53 \\
30 \mathrm{CFR} 221.55 \\
30 \mathrm{CFR} 221.56 \\
30 \mathrm{CFR} 182.23(\mathrm{e})\end{array}$ & $\mathrm{x}$ & $\mathrm{X}$ & $\begin{array}{l}\mathrm{x} \\
\mathrm{x} \\
\mathrm{x} \\
\mathrm{x} \\
\mathrm{x} \\
\mathrm{X}\end{array}$ & 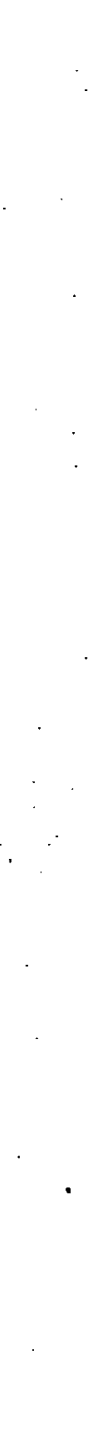 \\
\hline
\end{tabular}


FOOTNOTES

SECTION I

1. 25 U.S.C. \$477; see Maxfield, p. A-2.

2. The exact figure is confidential information of the Tribe.

3. Presented on pp. IV-20 thru IV-24 of Vol. II of the Planning Manual. The Model I approach entalls maintenance of current levels of management; Model II involves more activity in seek1ng trust assistance from Federal agencies; and Model III requires fuller development of Tribal management capacity.

4. Ibid.

5. 25 C.F.R. $\$ 182$ and proposed 25 C.F.R. $\$ 182$; discussed by Maxfield on p. A-4.

6. 25 U.S.C. $\$ 396 a$; discussed by Maxfield on p. A-3.

7. Personal communication from Bill Haltom, an attarney with Nordhaus, Moses \& Dunn, the Tribal law firm.

8. Proposed 25 C.F.R. $\$ 182.4$; discussed by Maxfield in footnote 154 on pp. A-62 and $A-63$.

9. See the discussion by Maxfield on pp. A-8, A-9, and A-20.

10. Note C.F.R. $\$ 182.4$; supra.

11. 30 C.F.R. $\$ 221.1$ et seq.; discussed by Maxfield on p. A-9.

12. 25 C.F.R. $\$ 182.22 ; 30$ C.F.R. $\$ 221.10-221.40$; djscussed in general by Maxfield in his section on Federal oil and gas operating regulations, Appendix A.

13. 25 C.F.R. $\$ 171.24,171.27(\mathrm{~b})$; discussed by Maxfield on pp. A-11 et seg.

14. 25 C.F.R. $\$ 171.22,171.27(\mathrm{a})$; discussed by Maxfield on pp. A-12 et seg.

15. 25 C.F.R. $\$ 171.21$; discussed briefly by Maxfield on p. A-10.

16. Internal USGS Fiscal Year 1978 budget documents,

17. 25 C.F.R. $\$ 171.18$; discussed by Maxfield on p. A-10.

18. 25 C.F.R. $\$ \$ 171,17-20$; discussed by Maxfield on pp. A-4 and A-13.

19. See Maxfield's discussion of tribal regulation through contractual terms, pp. A-13, $A-114$, and $A-115$.

20. See Maxfield, pp. A-27 and A-28. The case is not described in deta11 by Maxfield, but Ernst \& Ernst interviewed Navajo leaders in order to provide a summary of the case in this report. Briefly, the Navajo Tribe has clalmed responslbility for the enforcement of the Clean Alr Act on its reservation based on the legal princlples that States do not have jurisdiction over Indian lands and that tribes have the right 
to tax non-Indians on the reservation. Accordingly, the Navajo have imposed a tax on air pollution emissions from a power plant on the reservation. However, the New Mexico Environmental Improvement Division (EID) has prepared the State air quality plan in accordance with the Federal Environmental Protection Agency (EPA) regulations governing implementation of the Clean Air Act. Thus, the EID claims responsibility. for the enforcement of the air quality law on behalf of the Federal government in New Mexico. (The EID has been accorded similar responsibility for the formulation of a Statewide water quality management plan, also under. EPA regulations.) Although the case is in court, its resolution may come from a reformulation of EPA policies about Federal environmental regulation on Indian reservations.

20a. The Tribe has recently developed and is utilizing this procedure for gas taken in kind.

21. Civ. Act. No. 77-292 (12-29-77), 5 Ind. L. Rptr. F-24.

22. Thomas v. Gay, Utah and Northern Railway, and Moe (citations on p. A-83).

23. Maxfield; pp. A-87, A-115 et seq.

24. Maxfield, pp. A-115 et seq.

25. Maxfield, personal communication, $9 / 8 / 78$. 


\section{ENERGY MANAGEMENT NEEDS}

\section{BACKGROUND}

The Jicarilla reservation lies on the San Juan Basin in New Mexico, known for its vast oil and gas deposits. The Tribal reserves of natural gas and oil have been developed actively since the late 1950s. This activity has occurred pursuant to hundreds of leases and permits with private companies. Many of these are in force today. It is important to note that in the early 1970s, the Tribe discontinued the use of the standard BIA leasing format and chose to develop its resources by alternative contracting arrangements. At this time, three such agreements are in effect. Numerous royaity providing leases are still in effect as well. The Tribe is furthermore considering Tribally sponsored oil and gas development.

The Jicarilla Apache Tribe has adopted a fonnal statement of goals and objectives for its minerals management program, which are described in Section III. However, there are certain goals which are implicit in the activities that have been accomplished thus far: environmental preservation, land use controls, revenue maximization, and tribal training and employment.

The Jicarilla Apache Tribe has used its authority to adopt 
general ordinances to manage energy development on the reservation. At least three affect the minerals operations: (1) an ordinance requiring environmental impact assessments of all major developments; (2) an ordinance levying a penalty on all late royalty payments; and (3) an ordinance levying a severence tax on gas and oil production (currently in litigation--see Section I for discussion).

The Jicarilla Apache Tribal Council has established a special Natural Resources Committee to focus on such matters as energy development. Within the Tribal administration, the Tribe has established the 0 il and Gas Administration for implementing the Tribe's responsibilities under the joint venture operating agreement. The Administrator reports to the $\operatorname{Tr}$ ibal Council's Natural Resources Committee. Many of the long-term projects and policy matters are handled by the Tribe's economic development planner. Finally, the Tribal leadership and government staff have a close working relationship with the BIA Agency's Realty Office, which is responstble for the majority of lease management activities on the reservation.

At this time, the Tribal government is not staffed adequately to implement the programs it desires. The 011 and Gas Administrator currently handles all of the tasks associated with the two ventures. Because the contracts allow for funding other personnel that may be needed, the Administrator will be able to add staff as the workload grows. The Tribe has not assigned staff to implement the environmental impact ordinance, and the workload from the late payments ordinance has been added to the duties of the Tribal accountant. The economic development planner coordinates many of the other projects, but a very large percentage of the work is done by the Tribe's legal counsel and by other spectalists retained by the Tribe. 
At the BIA agency level, the realty office also has experienced additional staff persons would be needed to provide the minimum level of service needed by the Tribe.

RELATIONSHIP BETWEEN FEDERAL AGENCIES AND THE JICARILLA APACHE TRIBE

Monttoring and enforcing performance standards for o1l and gas operations on Indian lands are the general responsibility of the Department of the Interior (DOI). The DOI also analyzes the economic and technical feasibility of leases and other forms of agreement between the Tribe and the operating companies. The DOI must also approve any agreements signed by the Tribe. The BIA and USGS are responsible for carrying out the DOI's functions as described in the Planning Manual.

The Environmental Protection Agency (EPA) and other Federal agencles require the operating company to obtain certain permits (e.g., steam injection permits), but these permits do not involve the Tribe directly.

The general DOI responsibilities are expanded upon below for each DOI agency office having direct regular contact with the Tribe. The offices discussed are:

- USGS Southern Rocky Mountain Area office in Albuquerque and Roswell, New Mexico

- USGS District Office in Durango, Colorado

- BIA Albuquerque Area Office

- BIA Jicarilla Agency office in Dulce, New Mexico.

For each office the following points are covered: 
- Principal Contact and Staffing

- Current Activities

- Future Plans.

The section concludes with a discussion of opportunities for improving Federal-Tribe cooperation.

USGS Southern Rocky Mountain Area Office

Principal Contact and Staffing. The Area 011 and Gas Supervisor in Albuquerque is $\mathrm{Mr}$. J. W. Sutherland. Sutherland's staff in Albuquerque and Roswell includes 48 people handling lease accounts, 6-7 handling utilization agreements, and 3-4 processing leases.

Current Activities. The Area office is responsible for accounting, and technical matters involving other oil and gas production on al1 Fcderal lands and Indian reservations in the State of New Mexico, the State of Arizona, the southeast corner of Utah, and the southwest corner of Colorado. There are 4,800 leases belng administered in the area, 600 of which are on Indian lands, and 279 are on the Jicar1lia Apache Tribe Reservation. Thus, the Tribe's "fair share" of the Area office staff is approximately 3.4 full-time equivalents (six percent of the staff total).

Future Plans. There are no plans to alter USGS practice or staffing in the near future. The proposed new regulations for oil and gas leasing would not require the USGS Area office to maintain accounting records on joint ventures.

USGS District Office

Principal Contact and Staffing. Jerry Long is the District 
Englneer in charge of the Durango office. This District's staff includes three petroleum engineers, three inspectors, and two environmental scientists.

Current Activities. The Durango District is responsible for overseeing the technical and engineering aspects of oil and gas development in Northern New Mexico, Southwest Colorado, and Southeast Utah. Indian tribes in this District are the Southern Ute; the Ute Mountain Ute, and the Jicar1l1a Apache.

USGS District activities consist primarily of inspections of well drilling sites, rights-of-way construction and maintenánce, well pumping, and storage areas. Violations are cited directly to the operating company with notification going to the BIA Jicarilla Agency.

Future Plans. There are currently no plans to expand the Durango District oil and gas staff or its scope of activities.

\section{BIA Jicarilla Agency}

Principal Contact and Staffing. The principal contact in the BIA Agency in Dulce for energy matters is Harold Tecube, a member of the Tribe. Tecube is the head of the Agency Realty office. He is assisted by Gary Vicento, also a Tribal member, and one other staff person.

Current Activities. The BIA Agency Realty Office maintains lease records on all current and past leases. Data on file include the original lease, reports filed under the terms of the lease, and any lease modifications executed. The Realty office also maintains land ownership records indicating Individual allotments, lease tracts, and rights-of-way. 
Future Plans: The BIA Agency Realty office would like to assist the $0 i 1$ and Gas Administration in its efforts to monitor oil and gas operations tnore closely. However, increased funding for the BIA Agency does not seem likely, so current levels of activity will probably be maintained.

Opportunities for Improving Federal-Tribe Cooperation

As the Jicarilla Apache Tribe begins to manage its joint ventures actively, many of the inspection and record keeping techniques will be similar to those used by the USGS and the BIA. Since both agencies have extensive experience, the Tribe would benefit by transferring as much knowledge as possible from the Federal agencies. Therefore the Tribe should consider training accountants, inspectors, and other technical staff with some input frow those agencies. In order to get advice on regulating joint ventures diud In urder to increase tribal awareness of the status of leases, periodic meetings should be held with the USGS and the BIA.

IDENTIFICATION OF. ENERGY MANAGEMENT CONCERNS

Discussions with Tribal government staff members and legal counsel indicated that this phase of the Jicarilla's minerals effort would center on the following matters:

\section{Planning}

- Evaluating undeveloped leases

- Collecting data needed for development planning and enforcement

Making Development Decisions

- Formulating policies for unleased areas 


\section{Monitoring and Enforcement}

- Monitoring compliance with USGS regulations

- Implementing terms of settlements from prior litigation

- Implementing terms of current contracts

- Implementing Tribal ordinances

\section{General Management Activities}

- Redefining the roles of :DOI and the Tribe in minerals management.

The major concerns listed above create a need for a broad program of activities in the Tribal government. The following discussion reviews the management needs, focusing on the shortcomings of the existing activities in each area. Recommendations for management activities are presented in the subsequent section.

\section{Planning}

As used here, planning refers to the development of information needed by Tribal leaders when making all types of decisions--setting policies, approving projects, or enforcing contract terms. The Tribal and BIA staffs at the Jicarilla reservation indicated that both need to improve the quality, format, and accessibility of data in the following areas.

Land Use Data. The oil and gas development on the Jicarilla reservation has created an extensive network of roads and pipeline rights-of-way. The land consumed by these corridors represents a loss of the use of the natural resources, such as timber. Therefore, the Tribe would like to minimize the acreage devoted to these facilities. To do so will require closer scrutiny of well development plans to protect valuable 
resources and to encourage the joint use of existing corridors. The BIA and the Tribe currentiy are using maps provided by one of the major producers to do this type of analysis. However, these maps do not display the resource or land use characteristics of the acreage involved; their scale is too large to be used for an accurate assessment of alternative corridor routings; and they are not sufficiently up to date.

Lease Permit Records. It is important to know the status of all permits, contracts, inspections, or other actions that, are associated with a particular tract whenever Tribal officials are considering developing the area, checking for compliance with regulations, or responding to general inquiries. These records should be current and readily accessible for use by researchers. It would be optimal to have the data in both written and graphic form.

Neither the Trihe nnr the BIA hao develojec such a data base. Instead, the information is dispersed among different divisions within the BIA Agency Realty office, such as the Branch of Land Operations and the Forestry and Range Branches. At this time, the BIA maintains all lease and permit data. The BIA officials indicated that the current methods of storage and retrieval need to be improved. They do $\log$ in all new transactions, but there is little standardization for quality and consistency of the data that are included. Part of their work backlog is attributable to the fact that gaining access to the data and checking it for completeness are very time consuming. Also, the information is of ten difficult to analyze because it usually is in written form only. The Jicarilla Apache Tribe has developed a computerized data base for ofl and 
gas leases. Also, aggregation of data must be done by hand, a time consuming and costly process. Both the BIA and the Tribe indicated that it may be advisable to systematically computerize all such data.

Mineral Reserves Data. In order to select tracts for development, negotiate contract terms, or evaluate production trends, the Tribe needs data on the quality and quantity of its mineral resources. The quality of the data needed varies according to the decisions being made. In general, the expertise needed to do such analysis should be provided by the USGS. However; the USGS in general, and the Durango District office in particular, lacks the staff to do a reserve assessment.1/ Therefore it has been necessary for the Tribe to hire its own consultants to do studies on a case-by-case basis.

Environmental Baseline Data. The Jicarilla Apache Tribe has adopted an ordinance requiring environmental impact assessments of all major projects. Those who prepare and review these studies w111 need a consistent data base on the alr quality, surface and groundwater quality, climate, solls, vegetation, topography, etc., of the Jicarilla reservation. Data should be in written and graphic form.

Financial and Economic Analysis. The Jicarilla Apache Tribe has chosen to negotiate contracts instead of using standarálzed leases. In order to negotiate the financial terms effectively, the Tribe must have accurate and current information on ofl and gas pricing and development trends. Furthermore, other economic and financial analyses are needed to evaluate proposals for hiring provisions and for energy-related economic enterprises. Currently, no one in the BIA or the $\operatorname{Tr}$ ibal government collects or analyzes such data. 


\section{Making Development Decisions}

Any decision on whether to approve or disapprove a development project should be based on an understanding of how that project relates to the Tribe's goals, what impacts it would have, and what terms should be involved in the approved permit or contract. Numerous studies have Indicated that Indian mineral owners historically lacked this information when they reviewed lease offerings, and the Jicarilla Apache Tribe is no exception. However, the Tribe realized this difficulty and halted all lease sales in the early 1970s. The process of developing general policies and negotlating contracts has been evolving gradually since that time. The following discussion calls attention to the types of problems that the Tribe has encountered in this area:

Tract Selection. The first step in minerals development is to Identify tracts that are suitable for exploration and development. As discussed in the section on planning programs, there is no comprehensive data base on the minerals resources, other resources, or environmental baseline of the Jicarilla reservation. Thus, the Tribe has had to proceed very cautlously in proposing areas for development. Indeed, many of the tracts being considered are those suggested by private companies.

Contractual Agreement Form. It is an established policy of the Jicarilla Apache Tribe to utilize contractual forms other than standardized leases. At this time, the Tribe has standardized a joint venture/operating agreement format for ofl and gas development. However, each contract arrangement is treated individually. Obtaining the inftial approval of the 
DOI to use this approach took close to two years. Neither the agency, area, nor headquarters of BIA has the expertise that the Jicarilla Apache Tribe needs to analyze the legal, financial, or management merits of alternative contractual arrangements.

Impact Analysis. Each proposed permit or contract must undergo an assessment of its economic, environmental, and socioeconomic impacts on the Tribe. Again, the BIA staff does not have the expertise to do these analyses throughly. The BIA and USGS do prepare environmental assessments of all proposed projects. Finding these studies to be inadequate, the Jicarilla Apache Tribe has enacted an ordinance that requires the developer to do a detailed environmental assessment. However, the Tribe has not filled the staff position needed to review these studies.

Contract Terms. All approved contracts include conditions regarding income payments, environmental protection, hiring practices, and other concerns. Until the 1970s, the Tribe relied on the BIA's standard lease terms. With the advent of the operating agreement format, the Tribe has incorporated more stringent, Tribally oriented regulations. Here too the Jicarilla Tribe has not been able to rely on the BIA and the USGS for technical assistance. As a result, the Tribe has found it advantageous to retain legal and other specialists to advise and negotiate the contract terms.

Monitoring and Enforcement

Once a contract is approved, the Jicarilla Apache Tribe and the DOI comence activities to monitor the operation and enforce all contract stipulations. For the purpose of identifying problems and program 
alternatives, it is important to distinguish between the joint venture/operating agreements and leases. Key concerns are as follows:

Joint Venture Operating Agreements. At this time, the Tribe's most urgent need is to be able to monitor the accounting and auditing associated with each joint venture. There are two major reasons for this urgency. First, Tribal revenues are dependent upon the point at which "pay out" is reached. Therefore, it is important to ascertain that the company's records and reports are accurate in measuring this. Second, the USGS is not responsible for processing or verifying payments from joint ventures. Hence, the basic tasks associated with accounting and auditing them must be done by the Tribe. A clause in the agreements provides for the salary and expenses of the Tribal personnel needed to meet such " responsibilities. The Tribe's 011 and Gas Administrator has handled the initial accounting requirements of the existing contracts, but he indicated that the workload soon will require someone who is specifically skilled in ofl and gas accounting. Furthermore, he indicated the desirability of. automating the accounting process.

In addition to the accounting, the 011 and Gas Administrator must perform the following tasks:

- Review the well development plans to ensure compliance with the provisions for ofl and gas development

- Review plans for access roads and pipeline rights-of-way

- Monitor training and hiring practices

- Perform surface and environmental inspections to ensure compliance with contract standards

- Analyze reports on drilling, production; and other factors to ensure compliance with sound engineering principles. 
The BIA and USGS will be as involved in these tasks as they would be for operations under standard leases. However, as a partner concerned about the quality of these monitoring efforts, the Jicarilla Apache Tribe wants to acquire expertise to perform these tasks itself. Because the existing Tribal government personnel lack the necessary skills and special staff, this will likely involve a combination of new Tribal personnel and consultant contracts.

Leases. Under the existing regulations governing Indian oil and gas leases, virtually all of the authority to monitor and enforce the terms of the leases is vested in the DOI. The BIA manages the surface areas, and the ÜSGS manages the subsurface activities and the royalty accounting. As a general rule, the Tribe's role has been to monitor the DoI rather than to monitor the operators directly. The DOI's management of the Jicarilla nineral trust has been seen as deficlent by the Tribe. In the U.S. Court of Clains, the Tribe initiated court actions against lessees that included a broad complaint against DOI as the Trustee and a number of other cases that focus on particular aspects of DOI's activities. The analyses supporting these petitions and the court decisions have called attention to the following program needs.

The principal area of concern is royalty accounting. There are at least five tasks or issues that should be addressed.

- Accounting for overriding royalties. The settlement agreements from certaln cases required designated leases to remit overriding royalties directly to the Tribe. This creates additional demands on the Tribal accountant.

- Assessing and collecting late payment penalties. The Jicarilla Apache Tribe adopted 
an ordinance to levy a penalty on any late royalty payments. The standards and procedures to implement the ordinance were set up by specialists retained by the Tribe. The day-to-day administration must be done by the Tribal staff.

- Receiving royalty payments directly. The Tribe is investigating the possibility of having all royalty payments going directly to the Tribe rather than through USGS. If this transfer is approved, the Tribe's accounting functions would be expanded accordingly.

- Receiving gas in-kind. The Tribe also is Investigating its option to take its royalty percentage as gas in-kind rather than in monetary payments.

- Implementing the Tribal severence tax. The Tribe adopted an ordinance to levy a severance tax on production. This ordinance was challenged in court and still is under appeal. If approved by the courts, the Tribal accountants' workload would include assessing and collecting this tax from all producers.

A second area of concern ts sound reservoir management. The

Tribe wants to ensure that the rate and manner of development will ensure. maximum ultimate recovery and the optimal economic returns. Although USGS englneers are responsible for monttoring practices, the Tribe's participation includes the following tasks:

- Review of undeveloped leases to ensure compliance with requirements for oll and gas development

- Review of all leases due to terminate in order to determine whether there is production in paying quantities

- Oversight of drilling activities to ensure development of all of the productive zones under the lease.

Third, there are several environmental problems now being 
addressed by the Tribe. As noted in the discussion of planning needs, the Jicarilla Apache Tribe and the BIA feel the need to 1mprove the siting of all access roads and right-of-way corridors. Another concern is the quality of the surface inspections done by the BIA. The Agency officials Indicated that they were understaffed to do inspections on a reguiar basis. Also, there are no standards for elther evaluating the site or for reporting on the results of the inspections. This limits the effectiveness of any potential enforcement actions of surface violations. Finally, the Tribe also is becoming concerned about the long-term impacts of o1l and gas development on groundwater supplies. The Tribe will need to work with the U.S. Environmental Protection Agency, the BIA and the USGS to devise an acceptable plan to monftor underground injections (1.e., secondary. recovery of o11: and gas reserves).

One other management activity is the enforcement of hiring performance clauses. At this time, the Tribe's efforts have focused on notifying the operators of their pledge to comply with this stipulation. RECOMMENDED MANAGEMENT ACTIVITIES TO ADDRESS PROBLEMS

As a result of the preceding identification of energy management problems, we were able to formulate recommended activities for improved management. They are summarized in outline form below and then discussed in detail.

Summary of Recommended Energy Activities

$\underline{\text { Planning }}$

- Develop comprehensive data on reserves

- Develop environmental baseline data 
- Develop land use data

- Complete computerization of data base

- Develop oil and natural gas price tracking

system.

\section{Development Decisions}

- Establish periodic internal review of adequacy of contract terms

- Establish review of developer-prepared environmental assessments, especially for land use Impacts

- Monitor oil and natural gas prices continuously.

Monitoring and Enforcement

- Establish oil and gas royalty accounting procedures in anticipation of direct payments

- Establish audits of major joint ventures by independent certified public accountart

- Monitor hiring and tralning of Tribal members by oil and gas companies

- Expand reservoir monttoring/management.

\section{General Management}

- Improve liaison with DOI activitles

- Malntain closer contact with DOI inspection and review personnel

- Establish environmental Indicator system.

\section{$\underline{\text { Planning }}$}

The primary planning concern is lack of comprehensive information on reserves, environmental baselines, and land uses. The Tribe should identify the data needed, collect the data, and then, if cost effective, computerize the information to be compatible with the already automated ofl 
and gas lease data. The system selected should be user oriented, capable of graphic display, relatively easy to update, and able to simulate changes in land use patterns.

A complementary aspect would be the design of an oil and gas price tracking system. This would permit contracts negotiated at any time to reflect market trends and would assist in monitoring whether royalties being paid (or net revenues being distributed) are fair relative to going prices. Current price data would also aid in determining reserve status, i.e., whether it is economical to extract and market the minerals.

Development Decisions

Periodic review of contract terms is essential to making development decisions. The joint venture standard contract is newly devised and should be regarded at the outset as an experimental form of agreeüent. Several years after signing the first such agreement there should be adequate results for the Tribe to draw conclusions as to whether the contract is achieving Tribal employment, income, and environmental and land use objectives. In reviewing the results of contract terms, the participation of Tribal lawyers should be combined with that of an oil and gas economist, an economic development planner, and an environmental planner. To the extent that these functions can be filled by staff members who are familiar with data sources and the history of development, the Tribe will be able to conduct the review more cost effectively. If a review indicates inappropriate or inadequate contract provisions, then the terms of the standard contract should be revised accordingly. Furthermore, an attempt should be made to renegotiate contracts signed under the standard form that needed revision. Depending 
on the seriousness of the contract's inadequacies and the willingness of the company to cooperate in readjusting the terms, it may be necessary to seek judicial remedy. On the other hand, the review may show that the standard contract is producing the most cost-effective result for the Tribe. In either case, the standard contract should not be viewed as "cast in tron" and should be critically reviewed on a periodic basis. Part of this review should be based on the continuous tracking of oil and gas prices. This tracking system is essential for verification of royalty and revenue payments as well.

One of the main effects of the Jicarilla's exercising Tribal authority over ofl and gas development has been the ordinance requiring developers to submit environmental assessments of proposed actions. However, no one on the Tribal staff is currently trained specifically in environmental assessment. While Tribal members are developing these skills, the Tribe may wish to have outside assistance in reviewing companyprepared environmental assessments. $\underline{2}$ / This review would provide a basis for questioning particular features of a company's proposal and for seeking a corrective agreement with the company. If such a settlement cannot be reached, the review would provide a basis for requesting the appropriate DOI agency to conduct a more detailed Environmental Impact Statement (EIS) that might lead DOI to impose development restrictions.

In formulating guidelines for company-prepared environmental assessments, the Tribe may find it helpful to review the new Council on Environmental Quality (CEQ) guidelines for EIS preparation. These regulations should reduce the length and enhance the readability of EIS's compared to those of the past. The new regulations discourage the presentation of large quantities of unanalyzed, esoteric data and encourage 
language that is concise and to the point. The CEQ guidelines require federally prepared EIS's to be brief and to restrict the analysis to substantive issues. For example, CEQ suggests a page limitation and a summary section to identify and discuss reasons for analyzing substantive issues. In terms of content, the Tribe could refine its land use data base and control land use patterns by requiring the assessment to supply maps showing current and projected land use.

\section{Monitoring and Enforcements}

There are four major areas of monitoring and enforcement that could be improved:

- Accounting procedures

- Monitoring employment and training contract provisions

- Expanded reservoir monitoring

- Establishment of environmental indicators.

These areas are discussed in sequence below.

Accounting Procedures. In anticipation of the establishment of a direct payments procedure, the Jicarilla should evaluate the current accounting procedures and establish procedures reflecting sound oil and gas accounting practice. This topic is the subject of a detalled memorandum to the Tribe. A corollary accounting requirement is the establishment of uniform accounting standards on a well-by-well basis for other kinds of production-based revenue: the severance tax, late payment fees, and in-kind gas.

As a further check on the accounting of joint venture revenues; the Tribe should sponsor audits of the major producing contracts. A full 
annual audit performed by an independent certifled public accountant on a periodic basis would increase the probability of detecting financial mismanagement and thereby would help ensure that the Tribe is receiving its fair share of revenues. (These audits could also be performed in conjunction with the periodic review of contract terms mentioned above.)

\section{Monitoring Employment and Training Provisions. Certain}

development agreements provide training and employment of Tribal members. These provisions should be followed up on a contract-by-contract basis to make certain that, in the aggregate, Tribal employment and training needs are being met. For those contracts that are significantly under-performing, legal counsel can inftiate discussions of how better to meet the contract terms. Given that expansion of purchasing power and skills are essential to the long-term development of the Tribal economy, this monitoring activity may be the most important of all.

\section{Expanded Reservoir Monitoring. For each reservoir, the Tribe} will want the operator to pursue an optimal production strategy: producing at a rate that w11 maximize revenues while maintaining sound environmental and engineering practices. However, a given reservoir of ten involves several operators and numerous wells. The Tribe is in the best position to monitor the factors affecting the entire reservoir:

- Well spacing

- Rate of drilling ("diligent" development)

- Determination of productive zones exploited

- Gas/oil ratios

- Off-set drilling.

For new operatious, reservoir management standards can be set in the 
Tribe's review and approval of untization agreements. For existing operations, standards can be enforced through review of drilling and operating reports processed by the USGS and, if needed, by supplementary inspections.

Establishment of Environmental Indicators. The environmental problems associated with oil and gas development are generally easier to monitor and correct than for those associated with hard minerals development. The most difficult problem is undoubtedly pollution of ground water by steam injection; the process can force oil into aqueous veins (geologic formations that carry water underground), forming sludge or emulsions in the aquifer. Not only may the water being tapped by wells or seepling into streams be polluted, but the ofl can clog the porous geologic material carrying the water, thereby reducing the flow and the quantity of water transported. In an arid region such as northern New Mexico, pollution of groundwater and reduction of supplies is a very serious problem. Fortunately, detection is a fairly simple process for groundwater into which there are already wells (visual detection supplemented by gas chromatography if necessary). With the advice of environmental engineers, the Tribe could identify an easily testable indicator such as this for a series of pollutants. If tests indicate problems, petroleum engineers and environmental scientists could be called in for further investigation. If their investigation confirms that an oil and gas operation is causing the problem, then the company can be asked to rectify the problem, or, if this approach is not effective, the Tribe can seek DOI enforcement of regulations, or it might possibly consider court action. 
General Management Activities

In view of past difficulties with securing DOI implementation of trust responsibilities, the Tribe may not find the necessary support from DOI as tribal energy management activities accelerate. This is especially critical in the areas of inspections and review of operating plans. Of course, if the court cases against DOI result in higher funding levels for its trust activities, this may not be true. In either case, though, Tribal utilization of DOI assistance could be improved by assigning one person who is involved in oil and gas administration to serve as a liaison whth DOI inspection and review officials. The staff member assigned will be able to galn a detailed familiarity with DOI rules, procedures, and personnel and therefore will be able to maximize the assistance obtainable from DOI. Moreover, this individual will be able to advise the Tribe on those areas where DOI assistance is unlikely and pursuit of other channels might be more productive.

\section{SKILL REQUIREMENTS}

For each management activity above we have made preliminary estimates of the activity requirements by skill category (Exhibit II-1). Some part of these skịls could be supplied by Tribal staff (Exhibit II-2), and some part could be supplied by external consultants (Exhtbit II-3):

This assessment of skill requirements is somewhat preliminary. It represents a starting point for further discussions and evaluations in Section III. In Section III the recommended management activities are expanded to include timing, funding, training, hiring, and organizational considerations, as the Tribe's 011 and Gas Administration expands its role in energy management. 
EXHIBIT II-1

ACTIVITY REQUIREMENTS BY SKILL CATEGORY

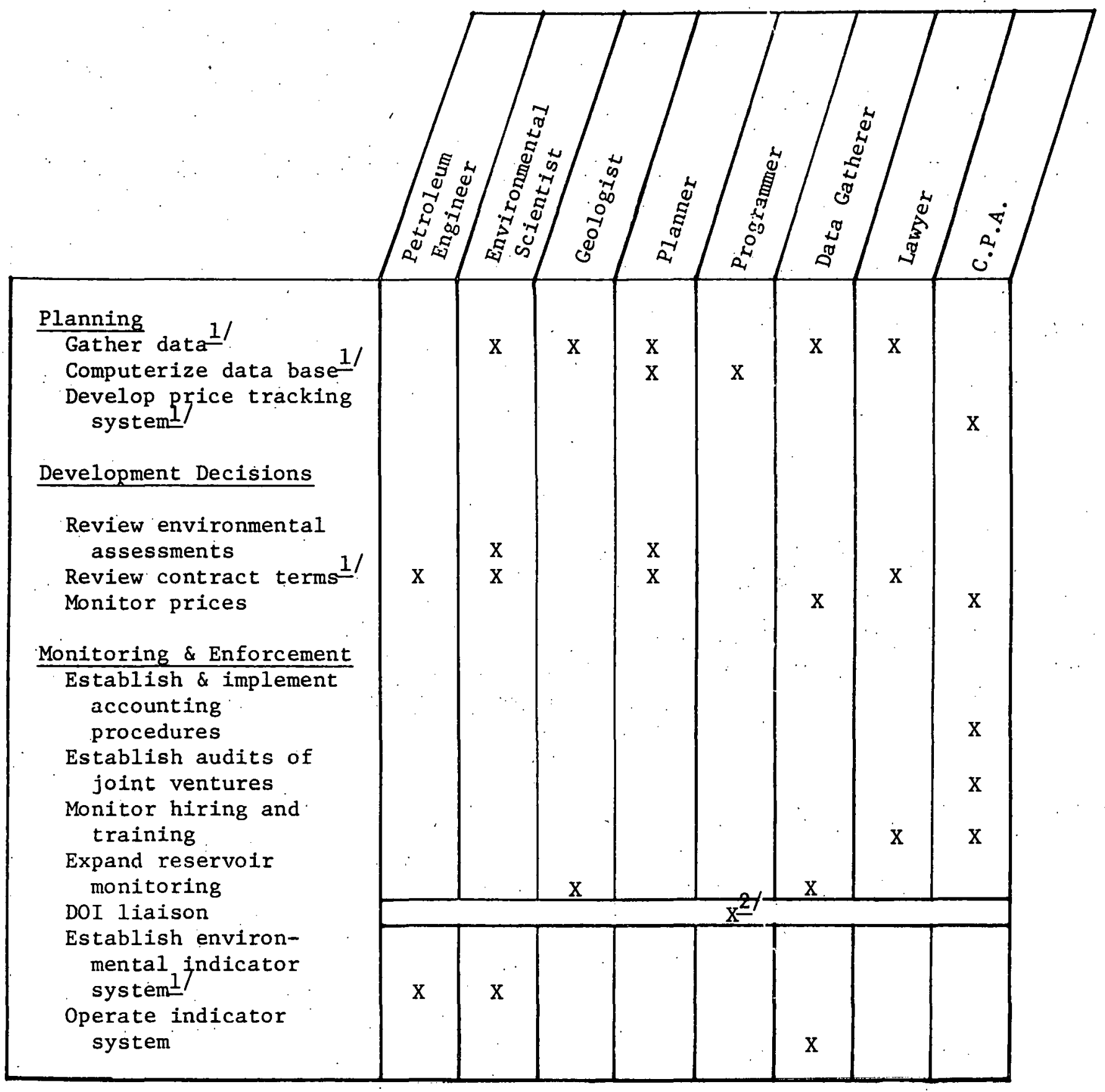

$1 /$ Infrequent or one time activities; other activities recur annually.

2/ Could be filled by any staff member with oil and gas knowledge. 
EXHIBIT II-2

PROBABLE TRIBAL STAFF ACTIVITY REQUIREMENTS

ASSISTANT TO THE OIL AND GAS ADMINISTRATOR

Monitor Reserves ("Pay Out,": Full Pumping of Producing Zones, etc.) Track Prices

Monitor Environmental Factors

Collect Data for Data Base

Monitor Hiring and Training

STAFF ACCOUNTANT

Assist in Tracking Prices

Assist in Monitoring Reserves (Calculating "Pay Out," etc.)

Maintain Joint Venture Accounts

Maintain Lease Accounts

ADDITIONAL RESPONSIBILITIES OF. THE OIL AND GAS ADMINISTRATION (May Require Staff Additions or Consultants).

Review Environmental Assessments

Maintain Liaison with USGS and BIA Inspection Review officials

Respond to Indicator "Flags" with Technical Investigation

Internal Review of Contract Terms

Oversee Reserve Monitoring

Oversee Data Base 
EXHIBIT II-3

SUGGESTED ACTIVITIES TO BE PERFORMED BY CONSULTANTS

AND ASSOCIATED TRIBAL RESPONSIBILITIES

\section{Collect and Automate Data Base}

- Consultant personnel required

- Environmental scientist

- Geologist

- Planner

- Programmer

- Frequency of study: once only; should include provisions for instructing Tribal members in operation and maintenance of data base

- Tribal activities required:

- Tribal lawyers supply lease data

- Staff member collects data

- Oil and gas administrator has initial input and reviews output

Develop Price Tracking System

- Consultant personnel required

- Financial analyst

- Frequency of study: once only; system should be designed so Tribal staff can take over operation

- Tribal activities required:

- Staff accountant assists consultant

$\underline{\text { Review Contract Terms }}$

- Consultant personnel required

- Petroleum engineer

- Environmental scientist

- Planner 
EXHIBIT II-3 (Cont.)

- Frequency of study: for each joint-venture contract, every five years

- Tribal activity required:

- Oil and gas administrator chairs task force of outside consultants

- Assistance from Tribal lawyers

\section{Establish Environmental Indicator System}

- Consultant personnel required

- Petroleum engineer

- Environmental engineer

- Frequency of study: Once only, system should be designed for on-going operation by Tribal staff; consultants may be called on occasionally to verify test results.

- Tribal responsibilities

- $0 i 1$ and gas administrator must give guidance to the staff in monitoring indicators 
FOOTNOTES

SECTION II

1. USGS FY 1979 budget documents

2. If a consultant is used, we suggest that the individual reviewing the assessment be a member of the National Association of Environmental Professionals (NAEP). NAEP members are environmental impact analysts by profession and are bound by a code of ethics to be independent, objective, and scientific in performing their duties. 
III. ENERGY MANAGEMENT PLAN FOR THE J ICARILLA APACHE TRIBE 


\section{INTRODUCTION}

The energy management plan presented in this section is intended for use by the Jicarilla Apache Tribe as it formulates and implements an energy development and management strategy. The plar begins with general matters and then discusses more specific points, as outlined below:

A. Goals and objectives

B. Energy management strategy

C. Rècommended energy management activities

- Short-term activities

1. Establish semiannual meetings with joint venture partners

2. Hold quarterly meetings with the USGS and BIA

3. Prepare quarterly letter report

4. Improve tribal computer system.

5. Improve Jicarilla Apache Tribe oil and gas joint venture information and accounting system

6. Establish an audit program for joint ventures

7. Use oil and gas joint venture accounting data in the budget process

8. Establish procedures for joint venture production monitoring

9. Establish procedures and criteria for 
environmental assessments of natural resource projects

10. Establish joint venture environmental inspection program

11. Select oil and gas market advisor

- Intermediate activities

1. Extend management activities to leases

a. Extend accounting system to leases

b. Collect and computerize lease data

c. Prepare lease revenue projections for use in budgeting

d. Extend production monitoring to leases

e. Extend environmental inspections to leases

2. Develop an automated land records system

3. Increase Tribal participation in energy development

a. Work with joint venture partners

and lessees to hire Tribal members

b. Begin limited exploration

4. Utilize Energy Resources for E,conomic Development

- Long-term activities

1. Increase Tribal control of energy resource development

2. Diversify Tribal economic base

D. Inplementation plan

- Organizational responsibilities

- Tining

- Staff/consulting responsibilities

- Cost/financing sources. 


\section{A. GOALS AND OBJECTIVES}

Based on discussions with the Tribal Planner, the Oil \& Gas Administrator, and members of the Natural Resources Committee, Ernst \& Ernst has prepared a list of energy management goals. Objectives for achieving each goal are also suggested. These goals and objectives are presented on the following pages.

In order to manage energy resources effectively, the Tribe should orient its specific energy management actịities to these goals and objectives. While implementing the plan, progress should be evaluated in terins of attainment of these objectives.

The Tribal Council should review the goals and objectives. After modifying Ernst \& Ernst's proposals as deemed necessary, a formal endorsement of goals and objectives by the Tribal Council would provide a firm foundation for energy management activities. This endorsement would constitute a general Tribal energy policy.

In the future, it may become necessary to formulate specific policies to cover each objective, as the Tribe has already done with its Environmental Ordinance and the Severance Tax. Drafting of such specific policies should be coordinated with the Tribe's lawyers. The general goals and objectives have been used in developing an energy managenent strategy (Section B) and in assessing needed energy management activities (Section C). 
PROPOSED ENERGY MANAGEMENT GOALS FOR THE JICARILLA APACHE TRIBE

General: To manage, conserve, protect, and develop the Jicarilla Apache Tribe's mineral resources for the benefit and well-being of the Tribe.

A. Economic Development

1. To maximize the potential income from oil, gas, and other minerals production.

2. To have a stable income from the oil, gas, and other production.

B. Environmental Protection

1. To protect and conserve the Jicarilla's riatural resources.

2. To improve the environmental quality. of areas that have been developed.

C. Employment

1. To maximize the number of jobs created by natural gas, oil, and other minerals activity.

2. To have tribal members interested and skilled in the energyrelated jobs.

D. Tribal Management Capability

1. To increase the Tribe's responsibilities in managing oil and gas operations:

2. To increase the Tribe's responsibilities in monitoring and controlling energy development.

3. To inprove the effectiveness of any Tribal management effort. 
SPECIFIC ENERGY MANAGEMENT OBJECTIVES BY GOAL

\section{Goal A.1 To Maximize Income From Production}

Objectives: To ensure proper rate of development of oil and gas reserves.

To ensure compliance with contract and lease terms for "maximum ultimate recovery" and diligent development.

To increase income or profits through contract and lease terms.

To obtain accurate and timely payment of all royalties or profits.

To increase income through tribal enterprise activities (e.g., tribal development of wells, subcontracting activities, and industries based on by-products or "in-kind" gas).

Goal A.2 To Stabilize Income From Production

Objectives: To ensure proper development of oil and gas fields.(e.g., compliance. with maximum efficient recovery and other engineering principles).

To invest revenues generated by production.

To diversify the Tribal economy through tribal enterprises based on energy activities.

Goal B.1 To Protect and Conserve Natural Resources

Objective: To mininize the impacts of oil and gas exploration, drilling, well sites, access roads, rights-of-way, and operations on other tribal resources.

- Wildlife

- Timber resources

- Rangel ands

- Air quality

- Water quality

- Visual resources 
Goal B.2 To Improve Environmental Quality

Objective: To reclaim existing and abandoned well sites, rights-ofway and roads.

Goal C.1 To Maximize Job Opportunities

Objectives: To include "hire Jicarilla" provisions in all leases and contracts (for direct and indirect jobs created).

To monitor and enforce any hiring provisions.

To create tribal enterprises based on oil and gas development.

Goal C.2 To Maximize Skills of Tribal Members

Objectives: To include training provisions in all leases and contracts.

To create an interest in careers in $n i l$ and gas.

To sponsor training programs for tribal members.

Goal D.1 To Increase Participation in the Management of Operations

Objectives: To enter into "joint ventures" (operating agreements) for new oll and gas development.

To evaluate the possibility of creating a tribal enterprise to develop ofl and gas fields.

Goal D. 2 To Increase Particlpation in Monitoring and Controlling Development

Objectives: To determine the appropriate mix of tribal and Department

of the Interior management activities.

To administer and enforce all Tribal ordinances relating to energy development.

To I1tigate matters involving violations of regulations or contract terms. 


\section{Goal D.3 To Improve Management Effectiveness}

Objectives: To define and improve the Tribe's working relationship with BIA and USGS officials responsible for minerals management .

To obtain all information needed to make informed decisions.

To systematize Tribal records on ownership, leases, permits, production, etc.

To train staff in skills needed to implement. Tribal. ordinances and other programs.

To evaluate alternative approaches for the placement of the minerals activities within the Tribal government structure. 


\section{B. ENERGY MANAGEMENT STRATEGY}

In pursuing the goals and objectives previously described, the

Jicarilla Apache Tribe must adopt a comprehensive management approach. Essentially, there are three options available to the Tribe, as discussed in Volume II of the Planning Manual:

- Reliance on the Department of the Interior's (DOI) activities to manage energy resources (Management Mode1 I)

- Better execution of DOI's trust responsibilities and supplementing these activities when needed (Management Model II)

- Total replacement of DOI as the responsible agent for minerals management (Management Model III).

However, the Tribe has three possible ways of developing its

resources over the long run, and the models apply to the available options to varying degrees. The types of resource development arrangements are:

- Development utilizing existing Federal regulations

- Development utilizing other than existing Federal regulations (e.g., developing additional monitoring and control systems and adding staff to carry them out)

- Tribal development regulations (e.g., joint ventures, service contracts)

The applicability of the models to each arrangement is shown in Figure III-1. Currently, the Tribe is doing little to actively manage its oil and gas leases, because this is the responsibility of the United States 
Geological Survey (USGS) and the Bureau of Indian Affairs (BIA). The Tribe has several active joint ventures and is considering other approaches to development. Following development and implementation of tighter management controls over joint ventures, some of these controls could be extended to leases, thereby supplementing USGS and BIA management. Finally, Tribal development of its own resources is not presently occurring, but development is possible in the future. Management of such operations would be solely the responsibility of the Tribe.

FIGURE III-1

ENERGY MANAGEMENT MODEL BY TYPE OF DEVELOPMENT ARRANGEMENT

Type of Development Arrangement

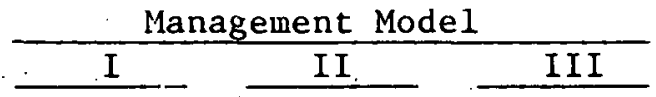

Existing Federal regulations

$\begin{array}{cc}\text { Currert } & \text { Future } \\ -- & \text { Current }\end{array}$

Current*/

Other than existing Federal regulations

Future

Tribal development

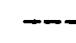

Future

* The Tribe is currently using a Model III approach for joint venture oil and yas accounting. 


\section{RECOMMENDED ENERGY MANAGEMENT ACTIVITIES}

The Jicarilla Apache Tribe's current organization chart is presented in Figure III-2. The chart also includes possible new organizational units that could be created to play a role in energy resource management. Current units of government that have a role in energy management are as follows:
A. Oil \& Gas. Administration
B. Tribal Planner's office
C. Accounting Department
D. Natural Resources Committee
E. Enterprise Board
F. Tribal Treasurer's Office

These units are circled on the organization chart. Possible new energy management units that could be created are:,

1. Energy Enterprise within the Enterprise Board

2. Apache Energy Enterprise, Inc.

3. Energy Enterprise within the Economic Development Department 4. Energy Resources Department

These new units are identified by broken lines on the organization chart. The alternative organizational relationships proposed for future energy management are listed at the bottom of the figure.

The set of energy nanagement activities described in Section II was modified in meetings with Tribal officials to reflect both the long-term goals and objectives and the immediate needs perceived by Tribal officials. These activities were reviewed by the Tribe's representatives 
FIGURE III-2

JICARILLA APACHE TRIBE ORGANIZATIONAL STRUCTURE AND POSSIBLE PLACEMENT OF ENERCY MANAGEMENT UNITS

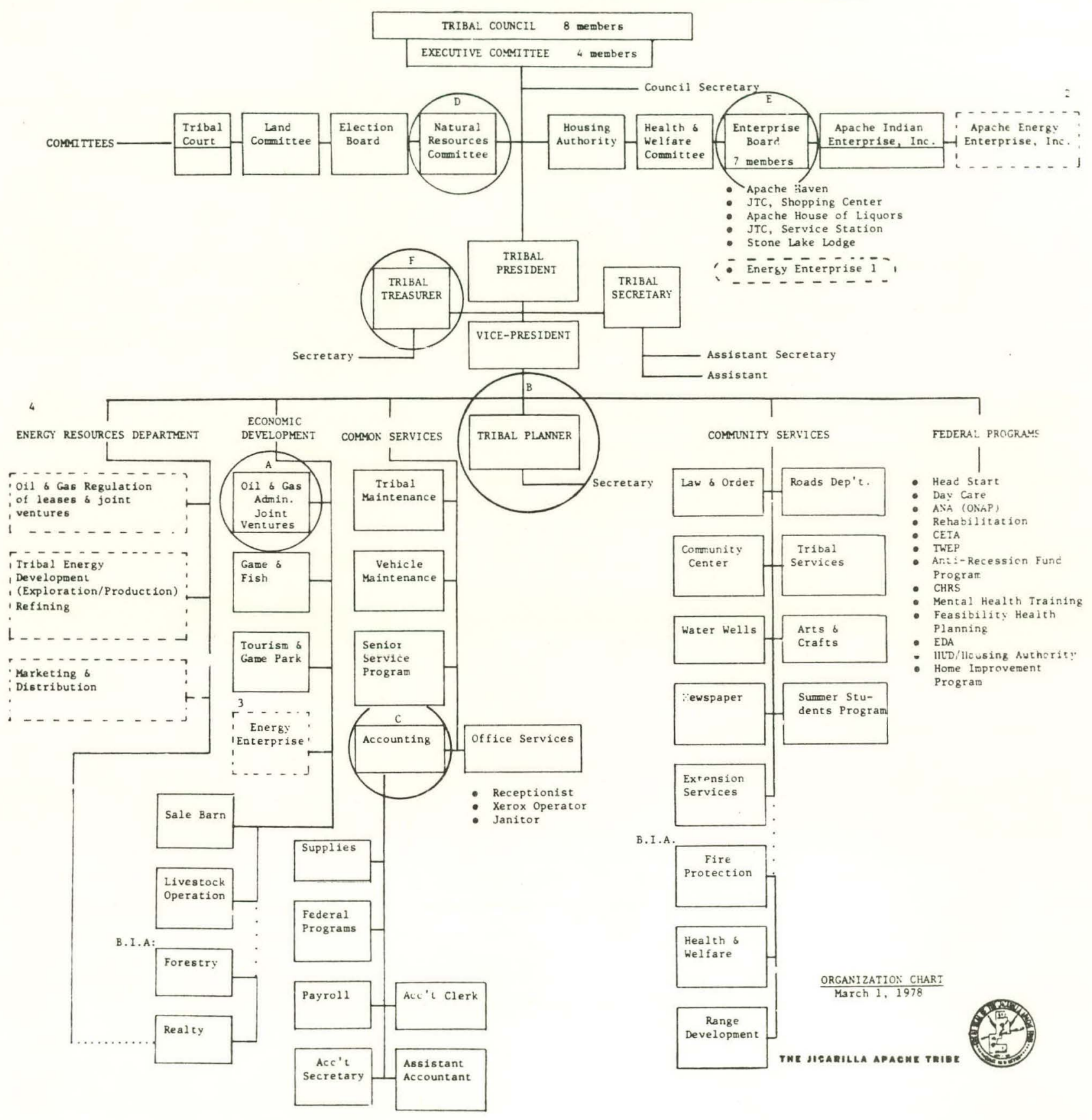

ALTERNATIVE I : Unit A for regulation; unit I for development ALTERNATIVE II : Unit A for regulation; unit 2 for development ALTERNATIVE III: Unit A for regulation; unit 3 for development ALTERNATIVE IV : Unit 4 for regulation and development. 
and subsequently modified by Ernst \& Ernst. The mutually agreed upon energy management activities are shown in Figure III-3.

Letters in the right-hand column of Figure III-3 indicate the organizational units in Tribal government that would be involved in each energy management activity as listed above. These responsibilities were formulated by assessing several factors:

-. The nature of the activity

- The capacity of existing organizational units in the Tribe

- The potential for changes in the Tribe's organizational structure.

The activities are divided into two general varieties: administration of resource development and direct development of resources. The first kind of activity must be implemented by a unit of government. For example, the $0 i 1$ \& Gas Administration (O\&GA), which has the administrative responsibilities for joint ventures, might eventually evolve into a department similar to those handling programs for economic development and community services, or O\&GA might remain as an office within the Economic Development Department. In contrast, development activities fit more logically into the Tribe's organizational arrangements for enterprises. For example, a Tribal oil and gas (or other energy resource) development enterprise might be incorporated as a separate entity like Apache Indian Enterprises, Inc., or it could be handled as one of the Tribally owned enterprises under the Enterprise Board, similar to Apache Haven or the Jicarilla Shopping Center. Another alternative would be to include the enterprise as part of an energy resources department or to include it under the Economic Development Department, as the Livestock Uperation is now placed. 
FIGURE III-3

PROPOSED ENERGY MANAGEMENT

ACTIVITIES FOR THE JICARILLA APACHE TRIBE

Short-Term (Immediate)

1. Establish Semiannual Meetings with Joint Venture Partners

2. Hold Quarterly Meetings with the USGS and BIA

3. Prepare Quarterly Letter Report

4. Improve Tribal Computer System

5. Improve 0il \& Gas Joint Venture Information and Accounting System

6. Establish Audit Program for Joint Ventures

7. Use Oil \& Gas Joint Venture Accounting Data in the Budget Process

8. Establish Procedures for Joint Venture Production Monitoring

9. Establish Procedures and Criteria for Environmental Assessments of Natural Resource Projects

10. Establish Joint Venture Environmental Inspection Program

11. Select Oil \& Gas Market Advisor
Organizational Unit(s) Involved
$A, B, D$
$A, B, D$

A

$A, B, C, E, F$.

A, C

$A, C$

A, F

A

A, B

A

$A, B, D, E$ 
FIGURE 3 (Cont'd).

Intermediate Term

Organizational

Unit(s) Involved

1. Extend Management Activities to

Leases

a. Extend Accounting System to Leases

b. Collect and Computerize Lease Data

c. Prepare Lease Revenue Projections for Use in Budgeting

d. Extend Production Monitoring to Leases

e. Extend Environmental Inspections to Leases

$$
\begin{array}{r}
\text { A, C } \\
\text { A, B } \\
\text { A, F } \\
\text { A } \\
\text { A }
\end{array}
$$

2. Develop an Automated Land Records System

3. Increase Tribal Participation In Energy Development
a. Work with Joint Venture Partners and Lessees to Hire Tribal Members
b. Begin Limited Exploration

$A, B$

A

4. Utilize Energy Resources for Economic Development

$A, B, E$

\section{Long-Term}

1. Increase Tribal Control of Energy Resource Development

2. Diversify Tribal Economic Base

$A, B, D, E$

$A, B, E$

KEY

$A=0 i 1$ and Gas Administration

$B=$ Tribal Planner's Office

$C=$ Accounting Department

$D=$ Natural Resources Committee

$\dot{E}=$ Enterprise Board

$F=$ Tribal Treasurer's office 
For the inmediate future, the 0il \& Gas Administration should continue to exercise its monitoring function as part of the Economic Development Department. The key activities presently performed by the 0il \& Gas Administration that should be continued include:

- Improve record keeping for in-kind oil and gas

- Monitor oil and gas prices and make revenue projections

- Monitor production and stripper well status

- Manage the Tribe's small producer certificate for natural gas as required by the Federal Energy Regulatory Commission (FERC).

Close ties to the Natural Resources Committee and to the Tribal Planner's Office should be maintained. After the operation becomes firmly established, that is, after all joint ventures are being regulated to the Tribe's satisfaction, then consideration should be given to upgrading the status of the Qil \& Gas Administration to an energy resource department. However, it should be stressed that this may not be necessary and should be judged on its merits when the time comes.

The development of a Tribal enterprise to produce and sell oil and gas is a long-term proposition. It will take several years of research and exploration to determine whether such an enterprise would be viable. The Tribal Planner's office should take the lead in evaluating the enterprise and coordinate its activities with the Enterprise Board, the Natural Kesources Committee, and the O\&GA. To facilitate coordination, it is suggested that the Planner work with the Natural Resources Committee.1/ The Committee should meet regularly to plan activities and to report findings that would influence the creation of an energy enterprise to the 
Tribal Council. The eventual placement of this enterprise in the Tribal organization structure should be determined by the Tribal Council based on the recommendations of this working group.

In the remainder of thị section, each activity listed in Figure III-3 is discussed in greater detail. For more complex activities, the following format is used:

- Organizational responsibilities

- Specific steps (subactivities) required

- Timing

- Staff/consulting requirements $2 /$.

- Costs/potential funding.

Because the specifics of many intermediate and long-term activities will depend on the outcome of short-term activities, it is not possible to provide as much detail on less immediate activities. As events unfold, it will be the responsibility of the organizational units indicated to carry forward the energy management planning process for these activities. 
SHORT-TERM ACTIVITIES*

* Included in these activities are the current functions being performed as listed on page III-16.

III-18 
SHORT-TERM ACTIVITY NO. 1--ESTABLISH SEMIANNUAL MEETINGS WITH JOINT VENTURE PARTNERS

In order to ensure that the Tribe's concerns are directly known to the joint venture partners, and so information car be passed from the partners to the Tribe; it is recommended that the Oil \& Gas Administrator begin scheduling these meetings immediately. Participants for the Tribe should include the $0 . i l \&$ Gas Administrator and one of the Tribe's attorneys. Attendance by a representative of the Natural Resources Committee and any interested council members should be encouraged. There are certain important activities of the Tribe addressed in subsequent activities that should be immediately discussed with joint venture partners at these meetings. 
SHORT-TERM ACTIVITY NO. 2--HOLD QUARTERLY MEETINGS WITH THE USGS AND THE BIA

Regular, formal communication with the USGS and the Bureau of Indian Affairs (BIA) is essential for Tribal energy management. The 0il \& Gas Administrator should schedule quarterly meetings to discuss mineral development activity and any problems that exist. As in the case of the meetings with joint venture partners, representatives of the Natural Resources Committee should be encouraged to participate. The basic agenda for the meetings would consist of a review of USGS and BIA activities that affect the Tribe (e.g., results of inspections and audits) and a review of the Tribe's progress toward implementing its energy management program and how that progress affects relations with the USGS and the BIA. 
SHORT-TERM ACTIVITY NO. 3--PREPARE QUARTERLY LETTER REPORT

The 0il \& Gas Administrator should submit a quarterly letter report to the Natural Resources Committee, the Tribal Council, and the Tribal President giving important information about oil and gas activities. The reports should be timed to follow the quarterly meetings with the USGS and the BIA (short-term activity No. 2) so that the results of those meetings can be included. The inforation initially covered should include those items listed below and identify status at end of last reporting period, changes during current reporting period, and status at end of current reporting period for each item.

- Lease data

--number of wells being drilled

--nunber of wells completed, but not producing

- - number of wells completed and producing

--number of wells abandoned (plugged or not plugged)

- number of active leases

--quantity produced (in barrels [bbls] for. oil and thousands of cubic feet [mcf] for gas) --dollar amount of royalty payments

--average price received ( $\$ / \mathrm{bbl}, \$ / \mathrm{mcf}$ )

--amount of in-kind gas sold

--average price received for in-kind gas sold $(\$ / \mathrm{mcf})$

- Joint venture data

--number of wells being drilled

--number of wells completed, but not producing

- number of wells completed and producing

- -number of wells abandoned (plugged or not p.lugged)

--number of active contracts

--gross revenues, expenses, profits, and net. profits payments

--quantity of oil and gas received in-kind

--dollar value of oil and gas received in-kind

--average price received for in-kind oil ( $\$ / \mathrm{bbl})$ and gas ( $\$ / \mathrm{mcf})$ 
- Progress on energy management activities

--improving Tribal computer system

--joint venture information system/accounting s.ystem

--establishing audit procedures for joint ventures

--establishing environmental assessment procedures

--establishing environmental inspection program.

--selection of and reports received from oil and gas market advisor

--intermediate and longer-term issues.

The report should include a brief narrative interpreting the above data and highlighting key areas (e.g., change in joint venture revenues from previous quarters and the reasons for the change).

As the energy management plan is implemented; there will be a greater number of activities on which to report. However, there will also be a greater body of accessible information available to the O\&GA, so preparation of the report. should bccome tasler. 
SHORT-TERM ACTIVITY NO. 4--IMPROVE TRIBAL COMPUTER SYSTEM

Organizational Responsibilities

Responsibility for improving the Tribal computer system is split between the Accounting Department and the O\&GA; since they are the principal users. A "steering committee," including the heads of these two departments and the enterprise board, should be created to manage the development and use of the Tribe's computer. This ccmmittee would report to the President and the Council, and would also be responsible for making sure the computer's capacity grows with the needs of the Tribe.

\section{Specific Steps Required}

Figure III-4 is a flow chart depicting the current and proposed future uses of the Tribal computer system in energy-related areas. It is the basis upon which a comprehensive assessment of the system should be undertaken as an imnediate activity.

In order for the Tribal computer system to provide the desired services, the steering committee should be concerned with the following activities:

1. Schedule Regular Meetings (Monthly at First, Then Perhaps Quarterly) to Review the Current Uses of the Computer and New Development Requests. This would enable the community to keep abreast of the computer's storage capabilities and processing requirements, as well as the user needs.

2. Assess Tribe's Current and Future Needs. Outside consultants would be used to conduct the necessary feasibility study that would identify data processing growth alternatives. The steering committee would be responsibie for managing the feasibility study from the Tribe's perspective. The comnittee would report its recommendation of the study's alternatives to the Tribal Council.

3. Improve the Tribe's Computer System. Before the Natural Resource. Information System can be computerized and conveniently utilized by the Tribal resource departments, it is 


\section{FIGURE III-4}

DEVELOPMENT OF TRIBAL

INFORMATION PROCESSING SYSTEM

Application

Current

Short-Term

Activity

Intermediate

Long-Term

Area

Processing

Activity

Activity

1. Central

Accounting

2. Jo1nt Venture

Oil \& Gas Accounting

3. Joint Verture Records

4. Extension of 0i1. \& Gas Accounting System to leases

5. Land Records System

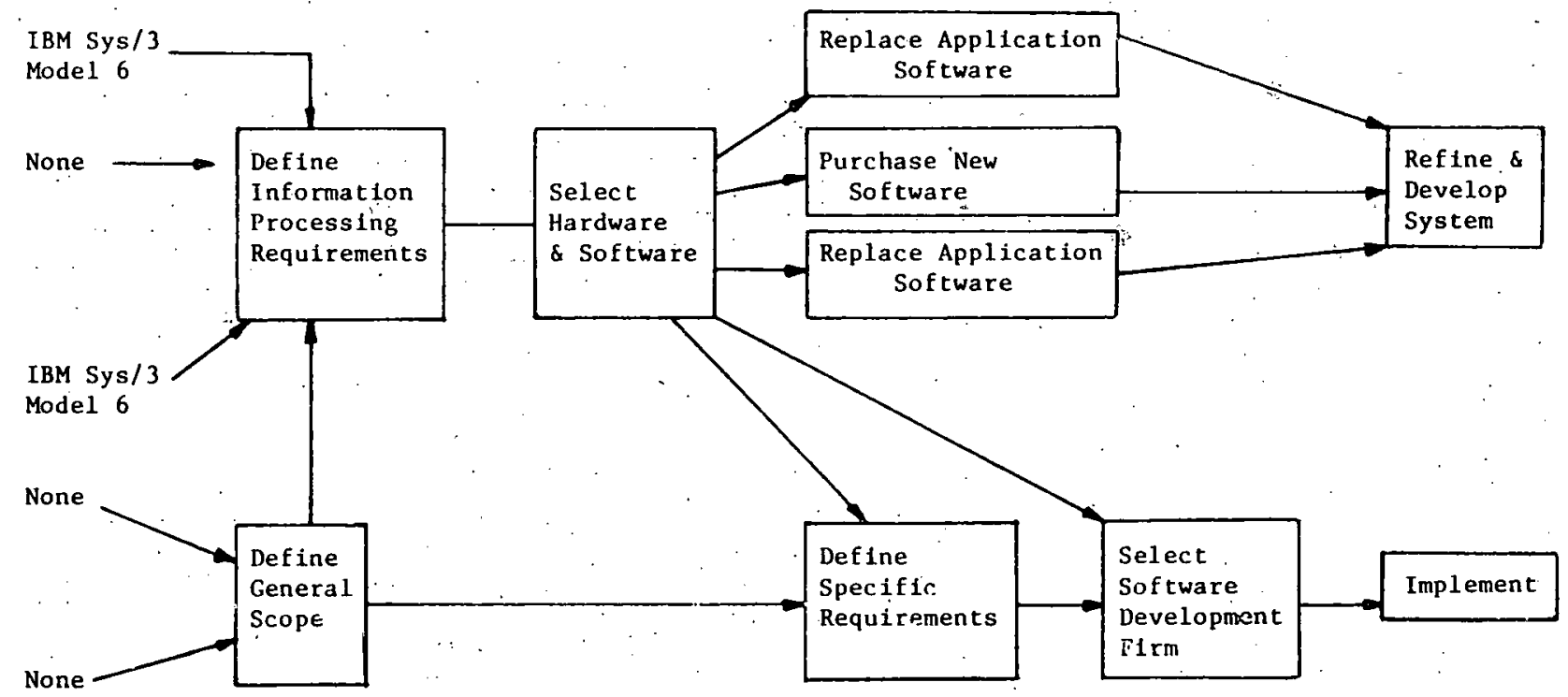


anticipated that the Tribe's computer will need to be improved. The specific needs will be identified as a result of the feasibility study conducted in Step 2. The types of improvements anticipated can be achieved either by replacing the current IBM System 3 Mode1 6 with a machine that has greater storage and processing capabilities along with the desired feature of remote terminal access, or by supplementing the existing computer system with a time sharing facility. This latter alternative would involve leasing telephone connections, terminals, and printers that hook up to computer probably located in Albuquerque or Denver.

Tining

Establishment of the steering committee can take place immediately. The assistance of external consultants should be considered as soon as the committee has identified current computer processing needs and has defined the desired future developments throughout the Tribal organization. This will probably take three or four committee meetings. Once consultants have been engaged, their feasibility study should take approximately three months. The time required for the implementation of the committee's recommendation cannot be determined in advance because it depends on the Council's actions, current computer lease arrangements, delivery schedules of the alternative systems (up to 18 months lead time), and the availability of necessary funding.

\section{Staff/Consulting Requirements}

The steering committee would provide all of the necessary management information and data requirements to 1mplement ongoing data processing system improvements; however, external consultants would be needed to analyze the Tribe's computer growth requirements. Specific program developments would require the services of a contract programmer 
and would be the financial responsibility of the department or departments that request the project. A project director should be named by the steering committee to coordinate the activity.

\section{Costs/Potential Funding}

The computer feasibility study would cost the Tribe from $\$ 4,000$ to $\$ 6,000$. Machine lease costs for the improvement alternatives could range from $\$ 750$ to $\$ 2,100$ per month. Money for this activity should be requested from the BIA under its trust responsibility. (The same rationale for requesting BIA funding pertains-to other activities where additional funds are needed.) 
SHORT-TERM ACTIVITY NO. 5--IMPROVE JICARILLA APACHE TRIBE OIL AND GAS

JOINT VENTURE INFORMATION AND ACCOUNTING SYSTEM

\section{Organizational Responsibilities}

The O\&GA is responsible for operating the joint venture accounting system. It should coordinate record keeping and information processing with the Tribe's accounting office, the BIA, the USGS, and the contract operators.

\section{Specific Steps Required}

Development of an independent oil and gas accounting system for joint venture agreements requires that the Tribe increase its capacity to manage the complexity of oil and gas operations, account for taxes, and deal with complex contractual arrangements. In order to facilitate growth in these areas, an oil and gas information system, which can later be enhanced to become the Tribal joint venture accouncing sÿstem, should be established. The following specific actions should be pursued:

1. Define what oil and gas information is necessary for purposes of monitoring earned revenue and production costs.

2. Design an oil and gas information system that will enable the Tribe to evaluate independently benefits derived fron each well and from each joint venture contract relative to the costs incurred and charged.

3. Implement the oil and gas joint venture information system.

4. Design an oil and gas accounting system that follows generally accepted accounting procedures, that is compatible with the Tribe's accounting system, and that utilizes information from the oil and gas information system.

5. Implement the oil and gas accounting system.

Once the O\&GA can independently monitor the Tribe's joint ventures, lease data and in-kind oil and gas payments should be included in the accounting 
system. However, this can only be done after personnel to handle in-kind

oil and gas operations have been hired and/or trained and after the oil and bas accountant has the joint venture system under control. Because eventual extension of Tribal management control over all operations (including small producer matters) depends in large measure on the quality of the initial joint venture accounting system, this report only details the steps necessary to construct the base system.

The following paragraphs identify the specific nature of each step listed above and their timing, staffing/consultant requirements, and costs/potential funding:

1. Review and Outline 0il and Gas Information Requirements

- Description of the step. Source documents, such as drilling reports, invoices and vouchers, production reports, and monthly well statements, should be reviewed for each joint venture agreement into which the Tribe is currently entered. The source documents then must be examined to determine the importance and completeness of the available information. Should necessary information not be available from the stipulated operator reports, alternate sources must be identified and researched until suitable sources have been defined for all required inputs. At a minimum, inputs should include quantity produced, price per unit, and production costs.

- Timing. Activity was completed by the 0il \& Gas Administrator in the summer of 1978 .

- Staffing/consultant requirements. The skills and staffing required to conduct this activity can adequately be supplied by the O\&GA with assistance from consultants.

- Costs/potential funding. Costs for technical assistance necessary for this activity have been fully absorbed by the U.S. Department of Energy contract with Ernst \& Ernst.

2. Design $0 i 1$ and Gas Joint Venture Information System

- Description of the step. The Tribal computer system should be evaluated for its ability to serve the O\&GA's 
processing needs. The needs must first be defined in the form of informational outputs for each well, each contract, and the entire department. Detailed well production data should be organized, as should revenue summary reports, for the joint ventures and the O\&GA. The initial step in evolving this information system into an accounting system is to design a revenue comparison report that will calculate earned revenue based on production data and compare it against actual revenue received from the operators.

- Timing. This activity also was completed by the combined efforts of Ernst \& Ernst and the 0il \& Gas Administrator. The system's initial design specifjcations were reviewed and approved in the early fall of 1978 .

- Staffing/consultant requirements. The O\&GA will need to utilize consultants in order to arrive at a workable and informative system.

- Costs/potential funding. Costs for this activity's technical assistance have also been fully absorbed under the Department of Energy contract.

\section{Impleinent the 0il and Gas Joint Venture Information System}

- Description of the step. Aseuming that tie Trlbal computer can handle the oil and gas information system (see above discussion of activity to expand the capability of the Tribal computer system--Short-Term Activity No. 4.), it will be necessary to contract the computer programming to an outside individual or firm. The programmer should be allowed to revise. the design specifications with approval from the O\&GA. Similarly, program testing and implementation onto the Tribal computer should be supervised by the O\&GA. The programmer will be responsible for training a designate of the O\&GA to input the necessary data and to operate the oil and gas information system. Ongoing programming assistance should be provided for system maintenance and future enhancements. All previous joint venture production data will need to be accumulated and put in the proper format for interaction with new operation data.

- Timing. Several tasks required for this activity have already been completed. The tasks of computer programming, testing, and system implementation should be concluded by the spring of 1979. After implementation, the information system should be able to handle new operating data as the data are generated; however, 
collection and input of previous production data will probably take an additional two months.

- Staffing/consultant requirements. The necessary skills and staffing for this activity include the services of a contract programmer. O\&GA personnel should be able to input system data and operate the computer. Daily information system operations should be controlled by the current O\&GA personnel.

- Costs/potential funding. Outside programming costs are estimated at $\$ 10,000$. All other activity costs are covered under the Department of Energy contract. Funds for contracting outside programming assistance have been allotted from the O\&GA budget. In the event that the current budget will not adequately meet the programming costs, the Oil \& Gas Administrator should request additional funds directly from the Tribal Council. A consulting programmer has been retained by the O\&GA and is currently providing assistance.

4. Design an $0 i 1$ and Gas Joint Venture Accounting System

- Description of the step. The Tribe will need to hire an experienced oil and gas accountant before further system design is done. Once hired, the accountant should review the oil and gas information system and the

operatnr-generated reporto to define the necessary accounting data for independent, joint venture accounting operations. The 0il \& Gas Administrator will be responsible for coordinating the design of the oil and gas joint venture accounting system with the Tribe's accounting office to ensure that the joint venture revenue accounts are consistent.

- Timing. This task should take approximately three months after an oil and gas accountant joins the O\&GA. Selection will probably take 10 weeks (to advertise, screen, interview, and hire). The selection process should begin as soon as the ongoing operations of the information system are under control. This means that completion of the ofl and gas accounting system should occur in the fall of 1979.

- Staffing/consultant requirements. Accounting expertise must be incorporated within the O\&GA at this stage. (A position description for an oil and gas accountant is provided as Figure III-ll in the implementation plan section.). Management and development skills are already within the O\&GA. To select a suitable accountant, candidates should be evaluated for their ability to work with the Jicarilla Apache Tribe. Screening of candidates 
for the position will require the assistance of consultants who conduct organizational staffing projects and who can also evaluate the technical competence of an oil and gas accountant.

- Costs/potential funding. The necessary costs for locating and hiring a suitable oil and gas accountant range from $\$ 22,000$ to $\$ 32,000$ (includes first year salary).

5. Implement the $0 i 1$ and Gas Joint Venture Accounting System

- Description of the step. Computer prograin changes will need to be incorporated into the information system. The O\&GA Administrator should coordinate the integration of the new oil and gas accounting system with the Tribal accounting system. Furthermore, he should be responsible for coordinating these activities with the operators and with the BIA and the USGS.

- Timing. Thịs task should be initiated as soon as definite design specifications have been determined. The initial joint venture accounting system. should then be implemented by January 1, 1980. After the joint venture system is successfully operating, the 0il \& Gas Administrator will be in a position to extend the information system to include lease production data and the accounting system to include lease revenue data.

- Staffing/consultant requirements. All of the necessary talents should be within the $0 \& G A$ for normal operations. However, when changes are made to the information system, it will be necessary to contract the services of a programmer.

- Cost/potential funding. Cost for this activity include additional programming and training, which are estimated at $\$ 5,000-\$ 10,000$. 
SHORT-TERM ACTIVITY NO. 6--ESTABLISH AN AUDIT PROGRAM FOR JOINT VENTURES

Organizational Responsibilities

The O\&GA is responsible for seeing that an audit program is òperation should be conducted each year by a firm of certified public accountants (CPAs). Each oil company has the actual responsibility of engaging the CPA firm; however, the Oil \& Gas Administrator should be sure to receive copies of all audit reports and management letters.

Specific. Steps Required

Considering that the audit is to be conducted by an independent CPA firm, the direct actions of the O\&GA are restricted to supervision. Communications and follow up with the joint venture operators should be handled on a timely basis and should involve the Tribe's lawyers, if necessary. The following actions should be taken by the oil \& Gas Administrator.

1. Request each operator to establish an annual joint venture audit by a firm of certified public accountants pursuant to Section XVII of the Joint Exploration and Development Ag reement.

2. Review the oil company's progress in selecting a CPA firm.

3. If insufficient progress is being made by the operators, consult the Tribe's lawyers about direct retention of a CPA firm.

4. Make available 0\&GA records to the CPA firm, assuming proper assurances of confidentiality are obtained.

5. Review all audit findings concerning the joint ventures.

6. Submit reports summarizing audit results to the Natural Resource Committee of the Tribal Council. 
$\underline{\text { Timing }}$

Audits are conducted every year on each joint venture operation once production has been established. If possible, a common year end should be established for all joint ventures. Timing of the audits should be agreed upon jointly by the 0il \& Gas Administrator and the operating companies.

\section{Staff/Consulting Requirements}

The skills necessary to review audit reports are presently within the Jicarilla Apache Tribe. Assistance should be sought from the Tribal Accountant for areas of uncertainty and for internal control analysis. The Tribe's lawyers can provide advice if any of the joint venture operators are not complying with their contractual obligation to engage independent auditors.

\section{Costs/Potential Funding}

The joint venture agreement requires that an annual audit be performed. The cost of the audit is included as a cost of production and charged to the joint venture before the net profits are distributed. 
SHORT-TERM ACTIVITY. NO. 7--USE OIL AND GAS JOINT VENTURE ACCOUNTING DATA IN THE BUDGET PROCESS

\section{Organizational Responsibilities}

The O\&GA should be responsible for forecasting joint venture revenues and expenses of the Jicarilla Apache Tribe. Detailed revenue and expense accounting should be handled by the O\&GA. Coordination between the O\&GA and the Tribal Accounting Office will be necessary to ensure that O\&GA budget estimates are compatible with the Tribe's budget format and account definitions.

\section{Specific Steps Required}

After the oil and gas accounting system has been implemented, the O\&GA should be able to estinate the expected future revenues and expenses by analyzing its previous accounting trends. At present, lease revenues and expenoc catimates should cume frum the BIA. Estimates tor in-kind production should come from the oil and gas accounting system, after it has been designed to handle in-kind operations. New joint venture developments will also impact budget estimates. Historic data should provide valuable guidelines to the O\&GA for estimating the impact of new developments and for judging the performance of existing producing wells. In order to relate oil and gas accounting data to the Tribal budget, the activities listed below should be followed:

1. The oil and gas accountant should identify all revenue and expense items and summarize their year-to-date totals for all joint venture agreements. These data can then be extrapolated into budgetary estimates. The oil and gas accountant should report figures to the $0 i 1$ \& Gas Administrator.

2. The Oil \& Gas Administrator should analyze the prior year's operations with regard to the growth in the number of joint venture wells. 
3. Geological and engineering reports and production forecasts should be obtained from joint venture operators, along with operator assistance in analyzing the data for effects on future joint venture revenue.

4. The O\&GA should review the production trends of each well. These trends should show important movements in the oil and gas revenues that would need to be included in the budget estinates.

5. New developments and new joint venture agreements should also be reviewed by the 0il \& Gas Administrator and by the oil and gas accountant.

6. The 0il \& Gas Administrator should continue to present revenue projections to" the Tribal Treasurer for inclusion in the Tribal budget. These projections should include detailed information on leases (royalties and in-kind gas) and joint ventures (net profits, in-kind ofl and gas).

Timing.

Because the budget preparation starts in April, the Treasurer's Office would need joint venture oil and gas revenue projections by March 1 of each year. Joint venture expense estinates would be needed in April. The timing for implementing this process is dependent on the hiring of an oil and gas accountant in O\&GA.

\section{Staff/Consulting Requirements}

All necessary personnel skilis for these activities are within the OdGA, exçept expertise in oil and gas accounting. After the O\&GA has hired an oil and gas accountant to manage development and operations of the oil and gas accounting system, the Tribe should be able to forecast joint venture revenues.

\section{Costs/Potential Funding}

Costs required to produce revenue and expense estimates from 
joint venture accounting data are included in the costs necessary to modify the oil and gas information system into the oil and gas accounting system. The forecasting assistance received from joint venture operators is without cost, pursuant to the Joint Exploration and Development Agreement. Hence, no additional funding is necessary for providing joint venture revenue and expense estimates to the Tribal budget process. 
SHORT-TERM ACTIVITY NO. 8--ESTABLISH PROCEDURES FOR JOINT VENTURE PRODUCTION MONITORING

Organizational Responsibilities

Because monitoring oil and gas production is central to

establishing a useful oil and gas information system and estimating future revenues from oil and gas production, this task should be carried out by the O\&GA. The O\&GA is in the best position to coordinate these related activities. After these activities are established for joint ventures, they can be extended to leases at the Tribe's discretion.

\section{Specific Steps Required}

In order to establish and implement procedures for monitoring joint venture oil and gas production, the following steps should be pursued:

1. Discuss proposed activity with joint venture partners

2. Survey existing joint venture wells

3. Design production monitoring system (including heat content and by-products)

4. Implement production monitoring system

The following paragraphs identify the specific nature of each step listed above and their timing, staff/consultant requirements, and costs/potential funding.

1. Discuss Proposed Activity With Joint Venture Partners

- Description of the step. As a first step, the 0il \& Gas Administrator and the Tribal attorneys should meet with each joint venture partner. The purpose of this meeting should be to express the Tribe's desire to establish a joint venture production monitoring program. At this meeting, several objectives should be pursued: 
--state the rationale for Tribal

production monitoring

--request relevant data about monitoring production and storage equipment used by the joint venture partners

--discuss the possible means of obtaining these data from the company

--outline the possible features of a Tribal well survey to obtain the needed data

--determine whether further meetings are necessary to establish the respective roles of the company and the O\&GA: in setting up the well survey.

Should this meeting determine that the Tribe must conduct a well survey to obtain the needed information, it may be necessary to hold further meetings, to make the necessary arrangements.

- Timing. This step should be taken as soon as it is possible for the Tribe and Tribal attorneys to set up a meeting. In any case, the decision on whether a well survey is needed should be made by mid-summer 1979. This will allow sufficient time to plan the scope of the survey, to locate summer interns or CETA employees to carry out the survey, and to set up an orientation session prior to the suminer.

- Staff/consultant requirements. This step will require no additional staff. It probably will require the participation of the Tribe's law firm and a consulting petroleum engineer.

- Cost/potential funding. The costs incurred here are routine-part of the O\&GA's normal operations. The additional expense will be for advisory services of a consulting petroleum engineer. The exact amount will be determined by the Tribe's demands on his time. A reasonable estimate is 40 hours at $\$ 50$ per hour, or $\$ 2,000$, plus expenses.

\section{Survey Existing Joint Venture Wells}

- Description of the step. Using interns or other temporary employees, the O\&GA should survey existing wells to obtain information needed to design a production wonitoring system. The information needed includes: 
Pumping characteristics

--type of well

--depth of well hole

--maximum capacity

--frequency (number of days per month)

\section{Measuring capabilities}

--gas: constant displacement neter, or orifice meter (2-3 day, 24-hour samples)

--oil: automatic level and temperature ganges; continuous measurement; or manual steel tape and thermometer readings through thief hatch

--qualitative analysis of by-products

\section{Transport facilities}

--type of separators used (potential for taking measurements): oil and gas separator, or oil and water separator

--method of transfer to pipeline: manually initiated, or automatic custody

The people performing the survey should go through an orientation session with input from USGS representatives, company representatives, and a consulting petroleum engineer, the last of whom will use the results to design a production monitoring system.

- Timing. Preparations for this survey should. begin in the spring of 1979. The survey would be carried out in the summer and the results presented to the consulting engineer in the fall.

- Staff/consultant requirements. The O\&GA will need to hire several temporary employees to conduct the survey under the leadership of the Oil \& Gas Administrator. A consulting petroleum engineer will need to provide advice and guidance to the survey project.

- Costs/potential funding. The only additional expense will be for interns or other temporary employees. Assuming three interns are employed for 12 weeks, each at $\$ 4$ per hour, the survey will cost about $\$ 5,760$. Approximately 40 hours of consultant time would be needed to give an initial orlentation and review interim outputs. 


\section{Design Joint Venture Production Monitoring System}

- Description of the step. The Tribe should select a petroleum engineer to design a production monitoring system. The Tribe should provide the consultant an opportunity to participate in settjing up the well survey in order to guarantee that the information collected will be useful. The Tribe should also allow the consultant to review intermittent results of the survey and to suggest any changes in data collection or recording techniques that may be appropriate. Once the survey is complete, the consultant will combine the information with any information provided by the joint venture partners. Note should be made of any missing data. This data base should be entered by the Tribe onto the oil and gas information system. Once this has been accomplished, the consultant will then be prepared to study the information and suggest a design for the production monitoring system. This design should include, at a minimum:

--a profile of all the joint venture wells by company, including location, capacity, and average pumping days per month

--a plan to sample the wells that is statistically valid

--a specification of the equipment and personnel needed to carry out the. sampling plan

- formats for recording the information that are consistent with the oil and gas information system (including. qualitative analysis of by-products)

--recommendations for extension of production monitoring to leases

- -an itemized, annual cost estimate for carrying out the plan

This design report will be submitted to the 0il \& Gas Administrator, who will use it to secure funding for the monitoring program.

- Timing. The consulting petroleum engineer will have involvement at several points prio: to the actual design of the system. First, during the early spring, he should assist in identifying information to be collected from the joint venture companies. Second, during mid to late spring, he should assist in identifying data to be obtained in the well survey. Third, at the beginning of the summer, he should provide guidance to the data collectors as to the desired format and ultimate use of the data. He will design the system over the fall, 
submitting a design report to the Oil \& Gas Administrator by January 1, 1980 .

- Staff/consultant requirements. This subactivity will require a consulting petroleum engineer and some time on the part of the Oil \& Gas Administrator.

- Costs/potential funding. The majority of consultant expenses will be incurred on this task. Four weeks of consultant time between September and December are anticipated. At the rate of $\$ 50$ per hour, the cost would be $\$ 8,000$ plus expenses.

\section{Implement Production Monitoring System}

Description of the activity. Once the 0il \& Gas Administrator has reviewed and approved the consulting petroleum engineer's report, a decision should be reached as to whether the potential benefits of the system outweigh the costs. If so, the $0 i 1$ and Gas Administrator should translate the proposed system into funding requests.

It is suggested that the joint venture companies might look favorably on matching Tribal funding of a pilot test of the system. The pilot test would establish a limited monitoring systeim (10-20 percent of the sample) to work out bugs, test the sampling plan's validity, and provide an indication of the actual benefits of the system. This idea should be discussed with joint venture partners at the earliest opportunity after the consulting engineer's report has been evaluated by the Oil \& Gas Administrator. A budget request, including an indication of the benefits to be derived from the project, and outside funding available, should be submitted as part of the Tribe's normal budgeting process.

Once funding for the pilot test of the system has been secured, it will be the responsibility of the $0 i 1$ \& Gas Administrator to:

- -hire and train the needed personnel

--procure equipment

-install equipment

--begin operation of the system.

As the system begins generating data, it will be the $0 i 1$ \& Gas Administrator's responsibility to see that these data are entered into the oil and gas information system. After the pilot system is in operation, a decision can be nade regarding implementation of the full system. 
When the full system is functioning, it should be possible to construct production histories for each sample well, to project production trends including quantity and mix of oil, gas and water, and to estimate trends for non-sampled wells. These data will also be useful in providing checks on the production data used by the joint venture partners to compute the net profits payments.

Timing

A tentative timetable for implementing the system spans two years:

--review design plan, January-Marci 1980

--seek pilot test funding from joint venture partners, February-March 1980

--present proposed budget, April 1980

--defend budget, May-June 1980

--begin arrangenents for implementation, May-June 1980

--hire and train staff, July-August 1980

--procure and install equipment, July-August 1980

--operate pilot system, September 1980-until satisfactory results are obtained

- review first quarter performance, December 1980

--analyze desirability of implementing full system, January-February 1981

--review second quarter performance, March 1981

--prepare budget proposal for full system, March 1981

--defend budget, May-June 1981

- Implement full system, July 1981-June 1982.

The primary factor affecting the schedule is the Jicarilla Apache Tribe fiscal year, beginning in July, and the accompanying budget cycle.

- Staff/consultant requirements. The extent of staff required will be determined by the $0 i l$ \& Gas Administrator based on his evaluation of the design report of the consulting engineer. The consultant should be available for consultation throughout this period.

- Cost/potential funding. The cost is difficult to determine at this time. The consultant report and the O\&GA evaluation of the report will be used to construct a budget for installing and operating a pilot system and, later, perhaps the full system. 
SHORT-TERM ACTIVITY NO. 9--ESTABLISH PROCEDURES AND CRITERIA FOR ENVIRONMENTAL ASSESSMENTS OF NATURAL RESOURCE PROJECTS

The Tribal Council in 1976 passed an Environmental Ordinance requiring that environmental assessments be prepared for proposed projects on the reservation. Since then, no explicit procedures or criteria for the assessments have been established. These are needed to guarantee prompt decision making and fair consideration for all projects and to make explicit the Tribe's environmental concerns.

\section{Organizational Responsibilities}

Because the Tribal Planning of fice is involved in most developments on the reservation, it is in a good position to act as the agency to establish the criteria and implement procedures for environmental assessments. The BIA is already responsible for preparing environmental assesstuents on lease related decisions. These assessments should be received by the $0 i 1$ \& Gas Administrator. At the Administrator's discretion, these assessments may be subject to the proposed procedure.

\section{Specific Steps Required}

The following steps will be required of the Tribal Planning Office:

1. Review possible environmental assessment criteria and procedures

2. Recommend criteria and procedures to the Tribal Council

3. Establish arrangements necessary to implement the procedures (in particular with the O\&GA).

Each of these steps is discussed in detail below.

1. Review Possible Environmental Assessment Criteria and Procedures. The Council on Environmental Quality has 
established minimum requirements for the content of environnental assessments. Each Federal agency in turn has tailored these guidelines to the circumstances of the particular agency. This is essentially what the Tribe should do. Figure III-5 represents a possible approach to developing environmental assessment standards for all projects.

An assessment is not a complete, detailed environmental impact statement. Instead, the assessment should be used to determine which environmental impacts may be significant, and therefore which should be analyzed further.

A possible procedure for coordinating the environmental assessment steps is shown in Figure III-6. The Tribal Planner should consider these possible arrangements and seek the advice of Tribal officers and directors of enterprises who might be affected by this procedure. In particular, the O\&GA should give guidance as to the type and scale of energy-related projects for which an environmental assessment would be desirable. It will probably be necessary to construct a list of projects which are exempted. For example, those might include:

--buildings requiring no more than $1 / 2$ acre and located more than $1 / 2$ mile from a surface water body

- Kange fences

--Repairs to existing roads

- -Replacement of existing oil and gas related equipment.

Once the Tribal planner has reviewed the possibilities for establishing an environmental assessment procedure, he should submit his recommendations in a report to the Tribal attorneys for their review. Final recommendations should be worked out between the attorneys and the Planner.

2. Recommend Criteria and Procedures to the Tribal Council. The Planner should first recommend the criteria and procedures to the Natural Resources Committee. With its concurrence, the criteria and procedures should be submitted to the full Council. The Council's decision to reject, accept, or modify the procedures and criteria will constitute the Tribe's formal policy on environmental assessment.

3. Establish Arrangements Necessary to Implement the Procedures. The Tribal Planner will have the necessazy forms prepared and will inform all Tribal offices of the new criteria and procedures. Likewise, the Tribal Planner and the O\&GA will 


\section{FIGURE III -5}

POSSIBLE ENVIRONMENTAL ASSESSMENT FORM

Project Name:

Project Sponsor:

Sponsor's Address:

Sponsor's Telephone:

\begin{tabular}{|c|c|c|c|}
\hline & \multicolumn{2}{|c|}{$\begin{array}{l}\text { Recelved: } \\
\text { Hearing: } \\
\text { Considered: }\end{array}$} & \\
\hline $\begin{array}{c}\text { Prepare } \\
\text { Detalled Study }\end{array}$ & Reapply & Denled & Approved \\
\hline
\end{tabular}

A. Attach a project narrative not to exceed 5. typewritten pages.

B. For each of the following environmental factors for which it is possible, please attach documentation that the project will not create significant environmental 1mpacts. Documentation for each point should be approximately 3-5 typewritten pages and should refer to the point by the appropriate number.

1. Soils

2. Geological Formations

3. Water Quantity

4. Water Quality

5. Air Quality.

6. Timber Resources

7. Grazing Resources

8. Fish \& Game Resources

9. Unique, Protecter, or Endangered Species

10. Displacement of Homes, Buslnesses or Public Facilities

11. Disruption of Public Services

12. S1tes with Archaeological, Religious, or Cultural Significance

13. Others (Specify): a)

b)

C. For the points above having signiflcant environmental impacts, attach a brief description of the nature and extent of fmpacts, and the plans formulated to minimize the impacts. Responses should refer to the point by the appropriate number and should be approximately 10-12 pages in length for each point.

D. Fallure to respond to any of the above points may be sufficient cause for rejecting the proposed project. Be sure to address all the points.

E. Submissions exceeding 100 pages for any one project will not be reviewed as an Environmental Assessment, but will require resubmission in Environmental Impact Statement format, in accordance with Federal Counc1l on Environmental Quality EIS guidelines. Unnecessarily elaborate or expensive submissions will not be accepted. 


\section{FIGURE III-5 (Cont.)}

F. The following statement must be signed by a representative of the party proposing the project (i.e., an officer of the firm, a responsible official of a government agency, a responsible Tribal official, or an individual Tribal member, as appropriate).

"I have reviewed the material submitted to the Jicarilla Apache Tribe as part of its Environmental Assessment. On the basis of the evidence presented, I contend that the project is environmentally. sound and requires no further, more detailed, study. I therefore request that the Tribal Council, or its designate, grant approval to the proposed project. It is my understanding that this approval is only on environmental grounds and the project may be rejected at a later date on other yrounds." 


\section{FIGURE III-6}

POSSIBLE PROCEDURE FOR ENVIRONMENTAL ASSESSMENTS

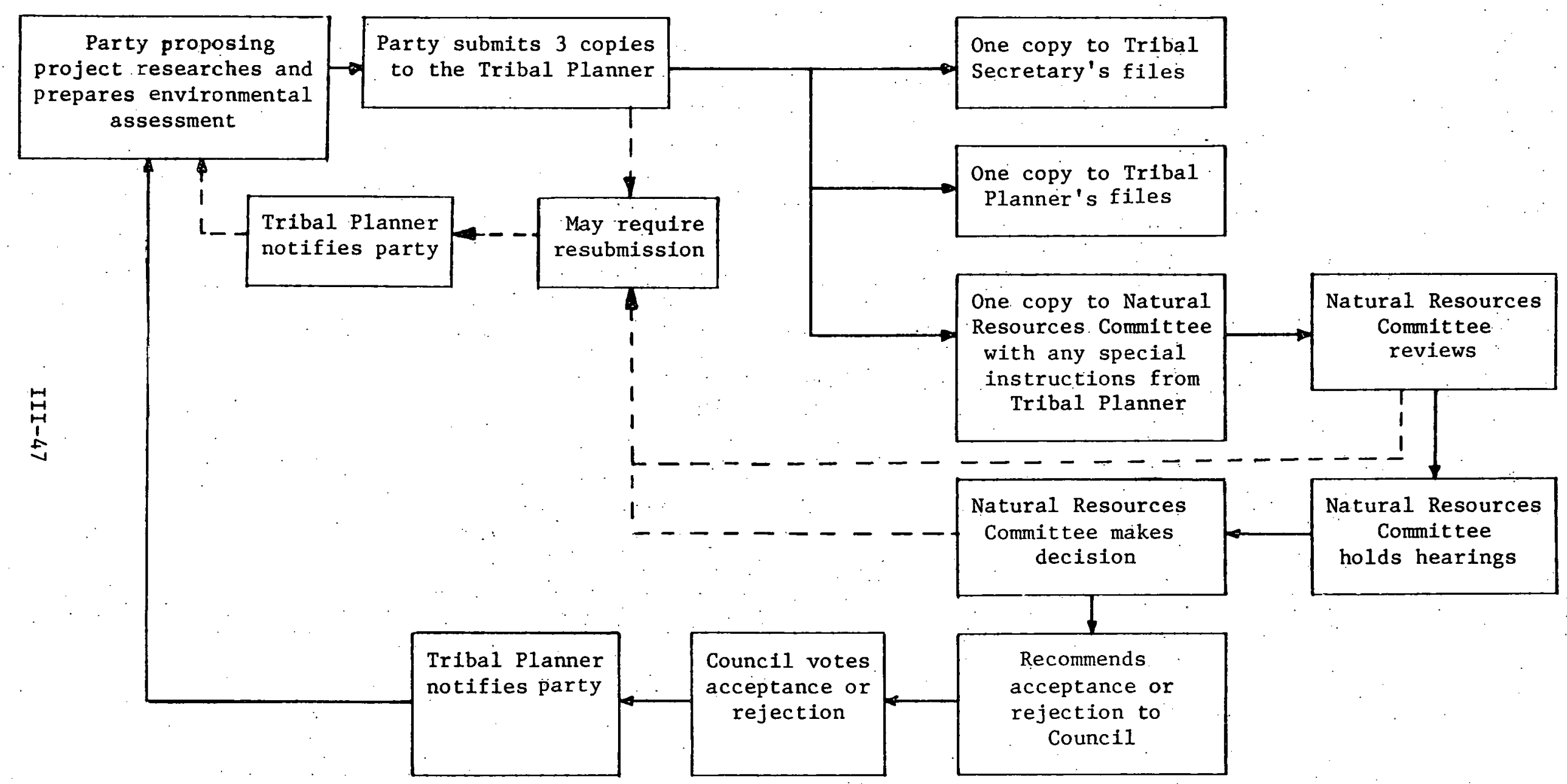


jointly inform all joint venture partners and lessees. The Planner will notify the BIA; and the BIA should be responsible for inforaing relevant Federal offices.

Timing

Because the Tribal Planner has numerous other responsibilities. and the Council has other priorities, it is not possible to estimate the time required to undertake and complete this activity. A reasonable target date for institution of the environmental assessment criteria and procedures would be January $1,1980$.

\section{Staffing Requirements}

The required staff and skills are already in place to begin this activity. Additional staff may be required depending upon the scope of the activity. If the procedures prove to be successful for natural resource projects, they could be extended to other types of projects.

\section{Costs/Funding Sources}

The time of the Tribal Planner responsible for this activity, plus any out-of-pocket expenses incurred (e.g., purchase of books, design and production of forms), should be charged to this activity. 
SHORT-TERM ACTIVITY NO. 10--ESTABLISH JOINT VENTURE ENVIRONMENTAL INSPECTION PROGRAM

The USGS is responsible for monitoring and enforcing environmental performance standards as part of the lease terms. The USGS also has this responsibility for joint ventures under current regulations. As pointed out in Section I, the proposed regulations are not entirely clear about whether this USGS responsibility would continue for joint ventures, though it would for leases.

In any case, Tribal officials view as inadequate the level of monitoring currently performed by the USGS. District office in Durango, Colorado. Given the uncertainty of USGS coverage of joint ventures, it is advisable for the Tribe to begin assuming environmental inspection responsibilities for the joint ventures, thereby freeing up more USGS time for monitoring of leases.

Organizational Responsibilities

The O\&GA has developed a working relationship with the USGS and has been performing other aspects of joint venture management. Therefore; it is the best organizational unit for handling the recommended activity.

\section{Specific Steps Required}

In order to assume environmental inspection responsibilities for joint ventures, the following steps are required:

1. Reach an understanding about the proposed activity with USGS representatives

2. Establish a pilot program for environmental monitoring of joint venture developments

3. Evaluate the results, benefits, costs and. effectiveness of the pilot program 
4. Establish a full program for environmental

monitoring of joint ventures.

Each of the steps is explained in detail below.

1. Reach an Understanding with USGS Representatives. At one of the quarterly meetings with the USGS and the BIA, the Tribe should initiate a discussion of the best method for Tribal environmental inspections of joint venture developments. This meeting should have several objectives:

- Inform the USGS of the Tribe's desire to augment USGS inspections in general and on joint ventures in particular

- Determine the training, staffing and equipment necessary to carry out a pilot program on one joint venture

- Inquire about interagency cooperation in setting up a pilot program for one of the joint ventures (e.g., training, sharing equipinent)

- Inquire about possible funding sources for the program.

If it is not possible to secure interagency cooperation in setting up the pilot program, perhaps the joint venture partners could be approached to provide training or equipment for the program.

2. Establish a Pilot Program for Environmental Monitoring of Joint Venture Developments. If the USGS is willing to cooperate with the Tribe, assistance should be used to design a monitoring system for one of the joint ventures. If USGS assistance is not available, the Tribe may have to use the services of a consulting engineer knowledgeable in controlling environmental degradation from oil and gas operations. The plan devised should stipulate:

- The number, type, and location of sites to be inspected

- The type of inspection to be conducted

- The frequency of inspections by site 
- The level of effort and equipinent requirements for a year and on a per inspection basis

- A procedure for reporting violations to

the USGS for enforcement of standards.

This design plan should be reviewed by the 0 il \& Gas Administrator. The 0il \& Gas Administrator in conjunction with the USGS and joint venture partner selected should discuss possible funding arrangements. Once external funding has been identified, the Oil \& Gas Administrator should prepare a budget request for the remaining share.

Once the Council has approved an allocation, then the 0il \& Gas Administrator should hire the needed staff, train the staff, procure the needed equipment, and begin conducting inspections.

3. Evaluate the Results, Benefits, Costs, and Effectiveness of the Pilot Program. Before extending the program to all joint ventures, the Oil \& Gas Administrator should prepare a report to the Tribal Council stating:

a. Any significant environmental probiems detected

b. What USGS enforcement action. has taken place as a result of Tribal inspections

c. What company corrective actions have taken place because of Tribal inspections

d. Whether company performance has improved because of the inspection program

e. What the costs were for the pilot program

f. What the $0 i 1$ \& Gas Administrator recommends about extending monitoring to all joint-ventures

- - funding

-timing

--level of effort (more or fewer inspections than pilot program).

If the Council decides in favor of expanded monitoring, then the 0il \& Gas Administrator would prepare a budget request for the full program. 
4. Establish a Full Program for Environmental Monitoring of Joint Ventures. The procedures for establishing a full program are similar to those for establishing a pilot program. In extending the full program to leases, the entire process described above, steps 1 through 3, should be followed. That is, the USGS should be involved from the outset, and the Tribal Council should make all major decisions.

$\underline{\text { Timing }}$

1. Reach an Understanding with USGS Representatives. This step should be taken at the first quarterly meeting held with the USGS and the BIA. This may provide enough time to prepare a pilot program budget for the FY 1980 budget cycle. If not, then an additional year is available for planning.

2. Establish a Pilot Program for Environmental Monitoring of Joint Venture Developments. This program would be staffed and equipped by September 1979, and would operate until June 1980. At that time, the Council would have the option of expanding the pilot program to all joint ventures, retaining the pilot program for another year of observation, or rejecting the environmental monitoring program altogether.

3. Evaluate the Results, Benefits, Costs, and Effectiveness of the Pilot Program. This would occur in March and April of $198 \mathrm{U}$ as the Oil d Gas Administrator is preparing the budget request.

4. Establish a Full Program for Environmental Monitoring of Joint Ventures. This would occur only if the 0il \& Gas . Administrator recommends, and the Council approves, an extension of the program. The earliest this might occur would be June 1980 .

\section{Staff/Consulting Requirements}

The Tribe may need the advice of an environmental engineer if the USGS is unable or unwilling to provide assistance.

Costs/Funding Sources

The environmental engineer should be retained for 40 hours of advice at an estimated $\$ 50$ per hour, plus expenses. The need for the Tribe to hire inspectors is an unknown and will depend on USGS and consultant's recominendations. It is possible that one of the staff members could divide 
tine between production monitoring and environmental inspections. In any case, production monitoring and environmental inspections should be coordinated to minimize costs.

Although the Tribe will be assuming two najor inspection responsibilities, the USGS will retain responsibility for petroleum engineering inspections on the following types of items:

- Abandoned operations

- Abandoned we1ls

- Exploratory wells

- Development wells

- Workovers

- Production equipment.

Until such time as the Tribe feels it would be cost-effective to hire a petroleum engineei, Llue responsibilicy and costs for these inspections should continue to be borne by the USGS. 
SHORT-TERM ACTIVITY 11--SELECT OIL AND GAS MARKET ADVISOR

The need for accurate information on the oil and gas market is especially critical, given the passage of coal conversion and natural gas pricing legislation, the partial deregulation of domestic petroleum markets, the decline of Iranian oil production, and the discovery of new oil and gas reserves in Mexico.

\section{Organizational Responsiblities ;}

The O\&GA should be responsible for selecting a firm to advise the Tribe on petroleum and natural gas markets. Because this advice will ultimately aid the Tribe in deciding whether and when to develop its own energy enterprise, this selection process should be coordinated with input from the Tribal Planner, the Natural Resources Committee, and the Tribe's law firm.

\section{Specific Steps Required}

The following steps are recommended to accomplish this activity:

1. Use contacts in the industry to generate a list of referrals. Extend a solicitation to referrals.

2. Screen proposals.

3. Conduct interviews with three to five finalists.

4. Select firm or individual.

Below, each step is discussed in detail:

1. Prepare a Solicitation. The O\&GA should put an advertisement in oil and gas trade publications asking for proposals to provide advice on oil and gas markets. Figure III-7 on page III-57 presents a sample of a possible advertisement format. Interested parties would write the O\&GA to receive'a "Work Stateinent" outlining the Tribe's specifications for the consultant. These specifications should include: 
- An indication of the type of information desired (price trends, production trends, impact of government regulations, etc.)

- An indication of the desired frequency and format for receipt of the information (newsletter, monthly meeting, quarterly seminars, and/or in response to specific inquiries by the Tribe)

- An indication of the Tribe's desire to work with a firm or individual with a good track record in working with Indian tribes and maintaining strict confidentlality

- An indication of the range of fees the Tribe is willing to consider

- A statement of the Tribe's intention to hire the consultant on an annual basis, subject to Tribal review

- An outline of the format for proposals, for example:

--qualifications and experience

--understanding of the situation

- wur'k jlau

--cost proposal

- A stipulation that unnecessarily elaborate or expensive proposals will not be accepted

- A stipulation that proposals over 50 typewritten pages in length (for all sections) will not be accepted

- Due date by which proposals must be received.

Upon receipt of the proposals, the 0il \& Gas Administrator should begin evaluating them.

2. Screen Proposals. The Oil \& Gas Administrator and the Tribal Planner should review and rate the proposals on the basis of their technical quality. Three to five finalists should be selected and invited to visit Dulce for interviews. 
3. Conduct Interviews with Finalists. The 0il \& Gas Administrator, the Tribal Planner, and one of the Tribe's attorneys should participate in the interviews, with Council members encouraged to attend. Based on the interviews, the technical ratings should be revised appropriately. One firm or individual should be contacted for negotiations:

4. Select Firm or Individual. The negotiations should resolve any outstanding issues regarding the scope of work, the scheduling of work, and the fee. Tribal attorneys should prepare an agreement for the Tribe and consultant to sign.

Timing

1. Prepare a Solicitation. This should be done in the early fall of 1979; i.e., after the Tribe has conducted the well survey, started its pilot program for environmental inspections, and instituted an oil and gas accounting system for joint ventures.

2. Screen Proposals. This should be completed by mid-fall of 1979 .

3. Conduct Interviews. These should be conducted by December 1,1979 .

4. Select Firm or Individual. Selection should be completed by January 1 , 1980 .

\section{Staff Requirements}

No additional staffing is required to select the oil and gas

market advisor.

Costs/Funding Sources

Since the Tribe is just begining to consider. Tribal development

of energy resources, the services required of the consultant should be

limited during the first year. Provision of background information with

little in the way of specific problem solving advice should not cost the

iribe more than $\$ 10,000$. 


\title{
FIGURE III-7
}

\author{
POSSIBLE \\ SOLICITATION FOR \\ OIL AND GAS ADVISOR
}

The Jicarilla Apache Tribe is considering an enterprise to produce, market and distribute oil and gas. In order to assist the Tribe in making sound development and sales decisions, the Tribe is interested in retaining a firm or individual knowledgeable about the mechanics of oil and gas markets and about Federal and state regulations pertaining to oil and gas markets. Interested parties should write to the following address to receive a more detailed "Work Statement" on which to base, proposals.

\author{
Mr. Thurman Velarde, Administrator \\ Oil and Gas Administration \\ The Jicarilla Apache Tribe \\ Dulce, New Mexico 87528 \\ Deadline for receipt of inquiries: September 1, 1979.
}

Telephone inquiries will not be acceptable. 
INTERMEDIATE ACTIVITIES

III-58 
INTERMEUIATE ACTIVITY NO. 1--EXTEND MANAGEMENT ACTIVITES TO LEASES

After instituting the program of short-term activities to manage joint ventures, the Tribe will be in a position to extend the same management techniques to leases. The managment activites would include:

- Extend accounting system to leases (major leases first)

- Collect and computerize lease data

- Prepare lease revenue projections for use in budgeting

- Extend production monitoring to leases

- Extend environnental inspections to leases.

The specific steps would be patterned directly after those described under short-term activities. The Natural Resources Committee should take into account several factors before going ahead with these activities:

1. Has the activity in question produced useful results on the joint venture?

2. Has the activity been accomplished at the expected cost?

3. Were the results worth the cost?

4. What difficulties might be expected for leases that were not encountered for joint ventures?

5. Have USGS and BIA activities improved to the point that the Tribe need not take prinary responsibility for these matters?

Establishment of the information system and accounting system for joint ventures is likely to exceed the present capabilities of the tribal computer system. Therefore, any extension of these systems to leases will rcquire an increase in the capabilities of the computer system as discussed under short-term activity No. 4 . 
The first three management, activities pertain to the Tribe's accounting and information systems. The O\&GA accountant would have primary responsibility for integrating information on leases into the joint venture system, working closely with the Realty office, where the records are presently maintained. Data collection, filing, and reporting requirements and procedures should be defined and documented as a first step. The desired inputs and outputs should then be reviewed by the Tribe's computer programmer. Programming requirements would then be defined, and funding requirements could then be determined. Control over lease data should not be assumed by the $O \& G A$ until its joint venture information system is firmly established and is operational. Computerization of lease data would then be incorporated in the development of the $0 i 1$ and Gas Accounting system, with lease revenue projections being generated by the system for incorporation in the budget process.

Undertaking the latter two management activities--production monitoring and environmental inspections--will again be determined by the results of the joint venture programs in these areas. These activities should be evaluated carefully because they could involve significant equipment and labor costs as well as out-of-pocket expenses for travel, testing, and so forth. 
INTERMEDIATE ACTIVITY NO. 2--DEVELOP AN AUTOMATED LAND RECORDS SYSTEM

Organizational Responsibilities

The O\&GA should be responsible for the design and computerization of land resources data and should direct the development of the Tribe's natural resource data base and information system. Lease data should be provided by the BIA Realty Department. The Water Wells Departinent should supply the current water well locations and water-bearing reserve information: The geological reports provided by the joint venture operators are the responsibility of the O\&GA. Additional geological data available to the Tribe should be computerized at the same time, since this information will probably be the same type and require the same computer characteristics. $\underline{3} /$ The activity should be coordinated with the current BIA-USGS mineral inventory study.

Specific Steps Required

The O\&GA Administrator should monitor the development of the system and should approve the organization of geological data and the design of output formats. Joint venture and lease contracts should stipulate assay sources available to the Tribe. Usirig these sources, a computer data base should be constructed so that the Jicarilla Apache Tribe can map ali available natural resources and plan for their future development. The following activities should be undertaken by the Jicarilla Apache Tribe to create its resource data base and information system:

1. Define Valuable Natural Resource Information. The O\&GA should determine the needed information regarding each oil and gas well, the Tribe's water supply, the Reservation's mineral composition, and the Reservation's environmental composition. 
2. Identify Resource Information from Joint Venture and Lease Operators. The department administrators should further identify the available data included in operator-generated geological reports, environmental impact statements, water-bearing strata reports, engineering information, and land maps.

3. Design a Natural Resource Data Base. A systems consultant should design the computer file layouts and the report generating programs. The resource data should be able to relate directly to the oil and gas information system. This will help generate accurate production and reserve estimates. Furthermore, the report generating programs should be able to accumulate data by specific land parcels. Each parcel should then have a complete resource file that is layed out identically to the files of other parcels. This allows information requests to easily access all files; consequently, specialized reports could be designed and generated quickly.

4. Provide Management Supervision Over All Computerization Developinent. The department heads of O\&GA, Realty, and Water Wells should provide management supervision over all computerization development. Development includes work on the initial system design specifications and the contract programmer's coding, implementation, and system training for the user departments.

5. Assign Representatives to Learn the Natural Resource Systems Capabilities and Requirements. Each department should assign at least one representative to learn the natural resource system's capabilities and requirements. Training these representatives will be the responsibility of the contracted programmer.

6. Transfer Data Output to Reservation Map. The output from the computerized data system should be transferred to a detailed map of the Reservation. Separate detailed maps could be maintained by each of the three resource departments.

$\underline{\text { Tiuing }}$

The initial stage of developing this natural resource data base is not dependent on any other activity. Definition and identification of desired data should start as soon as coordination can be established between the three Tribal resource departments. 
As soon as the desired data have been determined and located, a computer programmer should be hired, on a contract basis, to design the data base and to code the proyrams that will generate the special resource information reports. The programming effort should take approximately four months from the time someone is hired to the time the specified Tribal meiubers are trained on the completed system. All of the preliminary resource information.should be accumulated by the time data base input is necessary for program testing (approxtmately three months after the programming has begun).

\section{Staff/Consulting Requirements}

In the definition and identification activities, the joint venture operators should provide technical assistance, maps, and geological and engineering information relative to the lands covered by their contracts. This type of uperatur daca and assistance is stipulated in Sections VII and $\mathrm{X}$ of the Joint Exploration and Development Agreement. The design and implementation of a natural resource data base for the Jicarilla Apache Tribe will require the outside help of a consultant specializing in automated land records systems. All other skills and staffing requirements are currently present in the O\&GA and Kealty and Water Wells Departments.

Costs/Potential Funding

The Tribe should not incur any cost for technical information and assistance provided by joint venture operators because the operators are required by Sections VII and $X$ of the Joint Exploration and Development Ayreewent to provide such help to the Tribe. 
The consultant; will be an extra cost to the Tribe. The necessary design and programming could range widely (in excess of $\$ 50,000$ ). The Tribe should seek BIA funding for this project, as a demonstration effort with applicability to other tribes. 
INTERMEDIATE ACTIVITY NO. 3--INCREASE TRIBAL PARTICIPATION IN ENERGY

In the intermediate term, it is important for the Tribe to move beyond managing energy development conducted by others and to begin exercising its own: prerogatives. At first, thị will involve limited measures:

- Work with joint venture partners and lessees to hire Tribal members

- Begin limited exploration.

The first of these activities is a way to familiarize Tribal members with all aspects of oil and gas development as well as to provide immediate employment. In the joint venture contracts, there is an explicit provision to "hire Jicarilla." There are similar provisions in leases, and these provisions have become more refined during the last several years. Therefore, the hiring program should be pursued with joint venture partners F1rst. If successful, and if the Tribe still feels a need to hire more Tribal members, then negotiations should be opened with the more receptive lessees.

Before beginning any discussions on this matter, the Tribe should assemble an inventory of the background and experience of members interested in working for the oil and gas companies. The type of hiring to be sought with both joint venture partners and lessees should include management and administrative positions as well as operative positions. This will give the Tribe a pool of experienced ofl and gas personnel with a variety of skills on which to draw at such time as the Tribe elects to sponsor its own oil and gas enterprise. To this end, the Tribe should monitor the status and progress of members placed in jobs with the oil and zas companies. 
However, before the Tribe can make any decisions about sponsoring its own developnent, it is necessary to have a better understanding of the development potential of Jicarilla energy reserves. Based on the advice of the oil and gas market advisor (retained as one of the short-term activities described above), the Tribe should identify undeveloped tracts and classify them as follows:

- Development wells--sufficient data are available to justify their immediate development at a given threshold price

- Exploration wells--on tracts where there is known to be oil and gas, but for. which insufficient data are available to justify developmental wells

- Miscellaneous tracts--on which there is a possibility of exploration for other energy resources.

The decision to pursue any of these activities should take into account price trends in energy markets, the cost of exploratory or developmental wells, and the technical feasibility of exploration and preliminary. development. These activities will probably require that the Tribe enter into a contractual agreement with an exploration/development firm to perform these services for a Tribal enterprise. The exact nature and organizational placement of a proposed development should be worked out by mutual agreement among the O\&GA, the Tribal Planner's Office, and the Natural Resources Committee, with the approval of the Tribal Council and advice of the Tribe's attorneys. 
INTERMEDIATE ACTIVITY NO. 4--UTILIZE ENERGY RESOURCES FOR ECONOMIC DEVELOPMENT

The Tribal Planner's office should have as an intermediate goal the attraction of industries to whom the Tribe can provide its in-kind oil and yas. These would include industries using oil and gas as fuel (e.g., food processing, fertilizers) and industries involved in the refining or use of refined petroleum products (e.g., synthetic fibers, industrial chemicals). However, because the cost of transporting crude oil and natural gas is a relatively small portion of the price; it may be difficult for the Tribe to establish a decisive competitive advantage for these industries. The advantages of proximity to oil and gas production must outweigh the disadvantages of the relatively long distances to urban market areas, the relative difficulty of securing other raw materials required, the relative lack of skills and industrial work experience among the labor force, and environmental problems that could result. All of these issues should be evaluated before a campaign is conducted to attract industries requiring oil and gas. 
LONG-TERM ACTIVITIES

III -68 
LONG-TERM ACTIVITY NO. 1--INCREASE TRIBAL CONTROL OF ENERGY RESOURCE DEVELOPMENT

After exploration and trial development of resources, the Jicarilla Apache Tribe will be in a position to decide whether to sponsor full-scale development of its oil and gas reserves. Factors that should enter into this decision include:

- The nature and extent of reserves identified

- Resource price trends

- The type and extent of development contemplated

- The social and environmental impacts of development

- The management requirements for the Enterprise (e.g., service contracts or Tribal operation)

If the Tribe's demand for various technical skills reaches a fairly. constant level, then the Tribe may wish to hire individuals as Tribal employees (e.g., a petroleum engineer, or an oil and gas market advisor). In fact, the Tribe should constantly evaluate any consulting relationships it has: Is the Tribe using a consultant when it could get more and/or better output per dollar by hiring a staff member? 
LONG-TERM ACTIVITY NO. 2--DIVERSIFY TRIBAL ECONOMIC BASE

U.S. petroleum production is expected to peak around 1990. With that in mind, the Tribe should look beyond oil and gas and related industries for its economic future. This would include exploration and development of other energy resources and building on successful oil and gas related industrial development to attract other industries not dependent on oil and gas. An industry area that might be given more consideration is recreation and related retail goods and services. Also, investment of oil and gas revenues in Tribal infrastructure and services would improve the quality of life and make other types of economic development more likely. 


\section{IMPLEMENTATION PLAN}

The implementation plan for the Jicarilla Apache Tribe's energy uranagement plan has been developed from the individial activity analyses contained in Part $C$. The components of the implementation plan are as follows:

1. Organizational Responsibilities. Figure III-8 summarizes the responsibilities of Tribal organizational units for the short-term, intermediate, and long-term activities described in Part C. A "P" denotes primary areas of responsibility, while an "S" denotes a support role as identified in the activity work-up provided in Part C.

2. Timing. Figure III-9 presents the time-phasing of activities by year and quarter through 1980, with longer-term activities shown extending beyond 1980 .

3. Staffing/Consulting Responsibilities. Figure III-10 summarizes, by task, staffing and consulting requirements of the 0il \& Gas Administration, the primary implementation arm of Tribal government, to implement the short-term program. Figure III-11 contains a position description for an oil and gas accountant, the highest hiring priority for the Tribe in its short-tern set of activities. Training requirements and resources available for specific positions described in Figure III-10 can be obtained from Volume IV of the Planning Manual.

4. Cost/Financing Sources: Figure III-12 summarizes the specific cost elements that would be added to the Tribal budget (by administrative unit) of the short-term plan if fully implemented. Dollar figures are provided where they can be estimated with some degree of accuracy (based on the material contained in Part $\mathrm{C}$ ). However, the cost summary does not include the salary of the Oil \& Gas Administrator, whose position will continue to exist whether or not the plan is implemented, and whose salary is paid by the Tribe's 
present joint venture partner. In addition, the cost summary does not include any specific numbers for the intermediate-term or long-term plans, because the specific activities to be adoptéd are contingent upon implementation of the short-term plan. Figure III-13 presents a draft request for proposal (RFP) that was prepared by Ernst \& Ernst for the Tribe and used as the basis for retaining a consulting computer programmer to automate the Tribe's joint venture oil and gas accounting procedures in the 0il \& Gas Administration (short-tern activity No. 5--already under way).

The overall basis for determining the sucess of the implementation plan will be the degree to which it helps the Jicarilla Apache Tribe meet its objectives and attain its overall goals as described in Part $A$ above. To reiterate, the Tribe's primary goals and objectives pertain to:

- Economic development (level and stability of Tribal income)

- Environmental protection

- Employment

- Tribal management capábility:

The O\&GA will have to monitor its efforts toward attaining these goals and objectives on a continuous basịs and perhaps use the monthly letter report (short-term activity No:3) as a means of informing Tribal officials of progress :made. 
FIGUIRE LII -8

SUMMARY OF ORLANIZATIONAL RESPONSIBILITIES

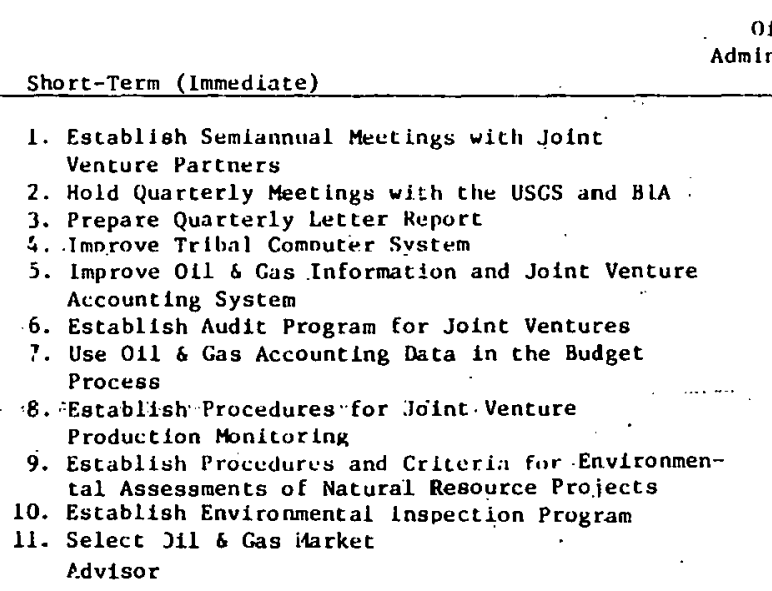

O11 \& lias Tribal Planner's
office

Nacural

Resurces Enterprise

Tribal

Board

Office

(A)

(C)

(F)

\section{Intermedlate Term}

1. Extend Management Activities to Leases

a. Extend Accouting Sycten to Leases

b. Extend Accounting Sycten To Leasea

c. Prepare Lease Revenue Projections for

in Budgeting

e. Extend Environmental Inspections to Leases

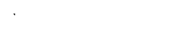

$\begin{array}{ll}\mathbf{p} & \mathbf{S} \\ \mathbf{p} & \\ \mathbf{p} & \\ \mathbf{p} & \\ \mathbf{P} & \\ \mathbf{P} & \\ \mathbf{P} & \\ \mathbf{P} & \\ \mathbf{S} & \\ \mathbf{P} & \\ \mathbf{P} & \end{array}$

Development

Development

Work with Joint Venture Partners and

Lessees to Hire Tribal Members 4. Utilize Energy Resources for Economic
Development

\section{Long-Term}

1. Increase Tribal Control of Energy Resource Development

2. Diversify Tribal Economic Base

$s$
$s$
-
-
-
-
-
-
s
P
-
s

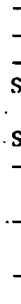

Letters underneath each administrative unit provide a cross-reference to Exhjbits 4 s. 5.

"P" Indicates primary unit responsible

"S" indicates secondary respeinsibitity 


\section{Short-Term (Immediate)}

1. Establish Semiannual Meetings with Joint Venture Partners

2. Hold Quarterly Meetings with the USGS and BIA

3. Prepare Quarterly Letter Report

4. Improve Tribal Computer System

- Assess Needs

$$
\text { - Amprove System }
$$

5. Improve 011 \& Gas Informatyion and Joint Venture Accounting System-

- Improve Information System

- Design Accounting System

- Implement Accounting System

6. Establish Audit Program for Joint Ventures

- Initiate. Request

- Review Progress

- Audit Conducted

7. Use 011 \& Gas Accounting Data in the Budget Process

8. Establish Procedures for Joint Venture Production Monitoring

- Discuss with Joint Venture Partners

- Survey Wells

- Design Monitoring System

- Implement Systen

9. Establish Procedures and Criteria for Environmental Assessments of Natural Kesource Projecto

- Review Criteria \& Procedures

- Approve Criteria \& Procedures

- Iuplement

10. Estabilsh Environmental Inspection Program

- Discuss with USGS

- Establish P1lot Program

- Evaluate P1lot Program

- Establ1sh Full Program

11. Select 011 \& Gas Market

Advisor

- Prepare Solicitation

- Screen Proposals and Conduct Interviews

- Select Consultant

- Monitor Performance

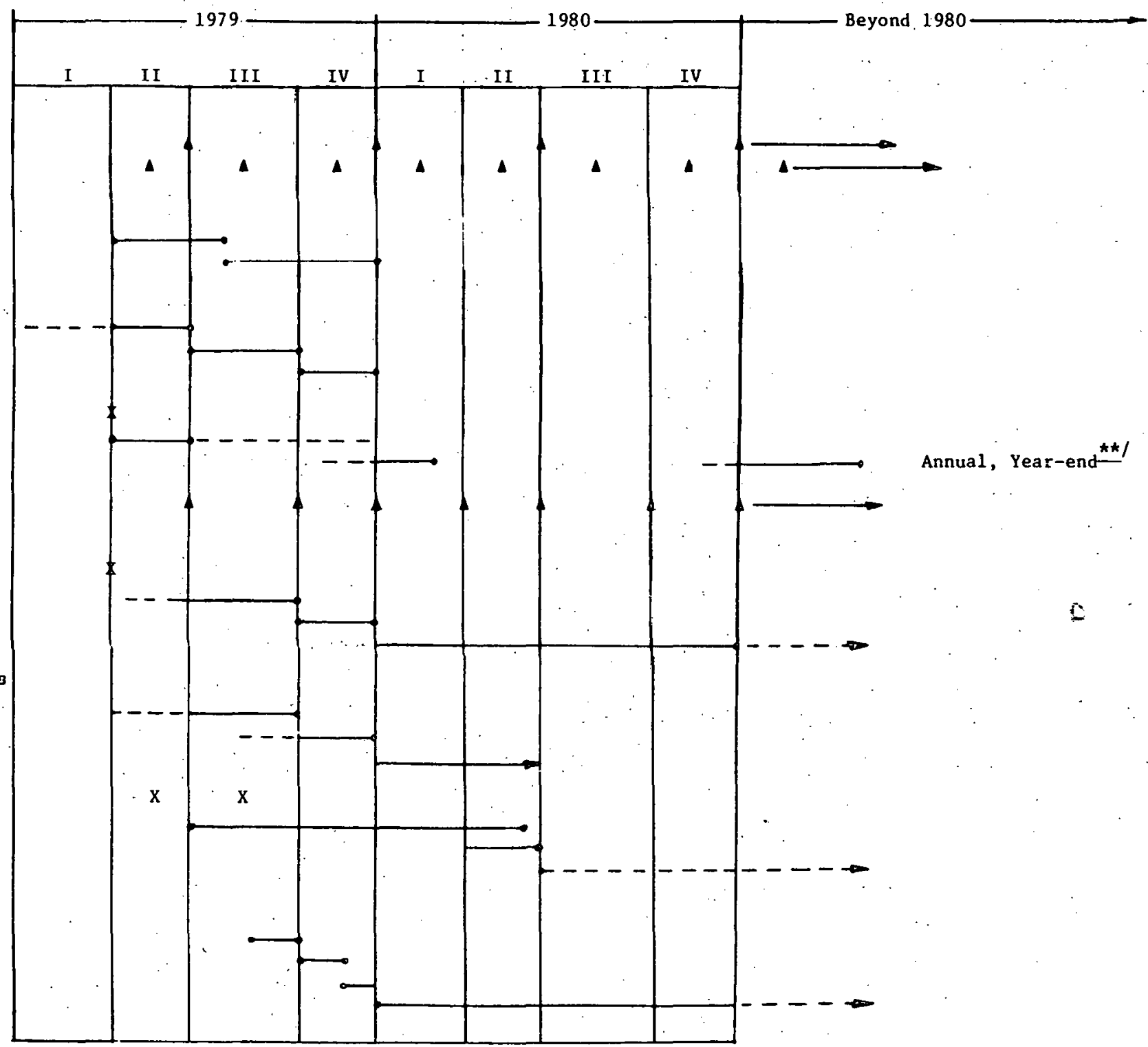

Roman Numerals Indicate Quarter of Calendar Year

- Indicates Meeting to be Held.

- Systems Design Completed by Ernst \& Ernst Fall 1978;

Computer Programming in Process. The highest

immediate priority is to hire a full-time ofl \& gas accountant.

$\star \star /$ - Shown as end of calendar year for convenience. 
FIGURE III-10

STAFFING/CONSULTING REQUIREMENTS

OF OIL AND GAS ADMINISTRATION TO IMPLEMENT

SHORT-TERM ENERCY.MANAGEMENT PLAN

\section{Activity}

1. Establish Semiannual Meetings with Joint Venture Partners

2. Hold Quarterly Meetings with the USGS and BIA

3. Prepare Monthly Letter Report

4. Improve Tribal Computer System

5. Improve $011 \&$ Gas Information and Joint Venture Accounting System

6. Establish Audit Program for Joint Ventures

7. Use 011 \& Gas Accounting Data in the Budget Process

8. Establish Procedures for Joint Venture Production Monttoring

9. Establ1sh Procedures and Criteria for Environmental Assessments of Natural Resource Projects

10. Establish Environmental Inspection Program

11. Select 011 \& Gas Market Advisor
Staff

Administrator: . 1-2 weeks semlannually

Staff Preparation: 1-2 person months sem1annually

Administrator: 1 week every quarter

Staff Preparation: $1-2$ person weeks quarterly

Adminfstrator: - 1 day monthly

Staff Preparation: 1 person week monthly after start up

Admintstrator Work with project director

Administrator:

Accountant :

Cont inuous monitoring

Project"Director; 2-3 days per week until operational

Staff:

Needed to work with accountant and run the system when completed

Administrator: Overall responsibility Accountant: .

Work with Tribal accountant and CPA firm

Accountant:

Staff:

\section{Overall responsibility}

Monitors data continuously

and prepares reports

Administrator:

employees :

Overali responstbility

3-5 staff for three-four months during spring/sumer 1979

Monitoring staff: Hire mid-1980; number unknown

at this time

Administrator coondinates with Tribal Planning office; staff in-place

\section{Administrator:}

Inspectors:

Overall responsibllity

Number and training depends

upon results of pilot program

developed by consultants

Accountant :
Coordinates selection of and information received from outside service(s)
Consultants

None

None

None

Required to conduct feastbility study and to conduct necessary programing

Required to design system, with contract programer implementing system on Tribe's computer

Select Certified Public Accountants (CPA's) to conduct independent annual audit

None

Petroleum engineer to design system and direct Tribal efforts

None

Use USGS staff as advisors and/ or retain environmental englneer

Selection of outside specialist(s) to provide regular reports and advice or use of CERT information exchange services (by subscription?) 


\author{
FIGURE III-11 \\ POSITION DESCRIPTION: \\ OIL AND GAS ACCOUNTANT \\ JICARILLA APACHE TRIBE \\ OIL AND GAS ADMINISTRATION
}

\title{
I. RESPONSIBILITIES
}

\section{A. Administrative}

1. Prepares monthly reports of royalty income and costs to the Natural Resource Committee.

2. Coordinates the financial activities of the oil and gas office with the tribal accounting office, the BIA, the USGS, and with all operators.

3. Maintains and revises as necessary the oil and gas office policy and procedure manual.

4. Advises the administrator of the oil and gas office and the Natural Resource Committee of developments or problems related to the accounting functions of the office.

5. Mantains files of accounting-related documents or records including:

- Payout status

- Statements of account (prepared by USGS)

- Collection reporțs (prepared by USGS)

- Payment (check) receipts

- Operator's monthly reports

- Schedule of royalty payments

- Income/payout/cost projections

- Estimated well costs

6. Develops a detailed understanding of the accounting activities performed by the USGS and BIA for the Tribe.

7. Reviews and analyzes in detail all accounting or financial-type reports received from the procedures or governmental agencies.

8. Maintains a record of current oil and gas market prices for each well or contract on the reservation.

B. Cash Collection

1. Maintains an Accounts Receivable Ledger for all lease contracts, in-kind oil sales and joint venture contracts. Reconciles this ledger monthly to the accounting department's records. 


\section{FIGURE III-II (Cont.)}

2. Monitors the ledger and takes prompt action to collect payment from past due accounts.

3. Maintains a file of all.wire transfers received.

\section{Joint Venture Accounting}

1. Reviews and analyzes the payout status reports and joint venture statements prepared by the operators and advises the administrator of any significant variances.

2. Requests each operator to submit annual forecasts of Tribal revenues.

D. In-Kind 011 Sales Accounting

(Possible function in future)

\section{E. Auditing Functions}

1. Reviews and reconciles all documents received by the oil and gas office monthly.

2. Verifies the market price of oil and gas sales.

3. Visits the operator!s administrative office and reconciles the sales and costs to the operator's records.

4. Analyzes the costs submitted by joint venture operators for proper classification.

II. REPORTING RELATIONSHIPS

- Reports to Oil and Gas Administrator

- Coordinates financial reporting and audit responsibilities with Tribal accounting department

- Maintains liaison with USGS and BIA officials

III. QUALIFICATIONS

- Degree in accounting

- Minimum of two years direct oil \& gas accounting experience

IV. SALARY 
FIGURE III-12

SUMMARY OF MAJOR COST ELEMENTS

INCURRED IN IMPLEMENTING SHORT-TERM ENERC MANAGLMENT PLAY

A. Costs Identified by Activity

\section{Activity}

4 - Improve Tribal Computer System

5 - Improve 011 \& Gas'Information and Joint Venture Accouncing System

- Verabe Accounc ping System

10 - Eotablish Environimental Inspection Program

11 - Select O11 \& Gas Market Advisar

\section{Description of Cost Element}

- $\$ 4,000-\$ 6,000$-- Feastbility Study and

Programing

- \$750-\$2,100 per month -- lease cost

- $\$ 10,000-$ - Computer progranuning

- $\$ 5,000$-- Implementacion.

- $\$ 2,000$ - Consulting petroleum eng1neer to design

pllot test $\$ 5,000-\$ 7,500 \ldots$ Interns to conduct survey (possible CETA . Funding)

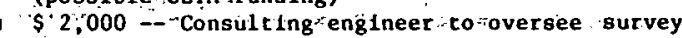

- $\$ 8,000-$ - Consulting engireer to design monitoring system

Implementation costs (unknown at this rime)

- Possible implementation costs (unknown at this time)

Possible implementation costs (unknown at th1

$\$ 5,000-\$ 10,000$ pe

B. Ceneral Cost Elements (OSGA Budget)

Labor

Adminlet rato

O11 \& Gas Accountant

ther Staff (as added)

Secreiarlal

Clerical

Subtotal

Fringe Benefit

verhead (Indirect Cost AIlocation)

Tot.n?
Other
Computer Purchase/Lease \& Usage

Publications

of fice Supplies

Training

Additional Contractual Services

Tota1

Ceneral d Administrative (G\&A)

Expense Applled to Labor \& Other

Equipment Purchase

- Motor Vehicles

- Office Equipment

- Testing Equipment

$1 /$ Costs are identified only for activicies that involve signilicant expenditures nver and ahove the presene osfin budget and the salary of an oll and fas accountiul if and when ane is ! i redl. 
PURPOSE: To apply for funds for the Jicarilla Apache Tribe to contract for computer programming services to autninate the joint venture oll and gas accounting procedures in the $0 t 1$ and Gas office.

AMOUNT OF FUNDING: It is est1mated that the necessary systems analysis, programming, testing, and documentation will require contract services costing $\$ 10,000$.

BENEFITS: Automation of the recordkeepting currently being done in the 011 and Gas office will eliminate the necessity of hiring an additinnal tralned hookkeper. Better accuracy of calculatinns and timely detection of recordkeeping errors should result In improved tribal control over the joint venture operations. In adiftion, autnmation should allow the Tribe to analyze the profitahilte and other business aspects of joint venture oil and gas operations.

BACKGROUNU SITUATION:

1. The Jicarilla Apache Tribe currently uses an IRM System ?, Model 4 computing system to process tritial accounts. The system is located in the trlbal headquarters bullding. This system, it is estimated, is used $50 \%$ of the available time thus allowing other appications to be implemented. such as the joint venture ofl and gas accounting.

2. The Trtbe currentiy does not employ a computer programmer. All programming is contracted to an outside programmer. The IBM system required all programs to be ended in a computer language called RPG-II. It is belfeved that such outside programming services can he contracted at the rate of $\$ 15.00-\$ 20.00$ per hour plus travel expenses.

3. Currently the 011 and Gas office recelves reports of Joint venture revenues and expenses as well as data on well production from each joint venture partner. These reports must be checked for accuracy of calculations and monitored for reasonableness and progress toward payout. Each well' is monitored using a separate accounting ledger and hand calculating and posting data to the ledger. For the number of wells currently $t r_{1}$ joint 
venture production this task can he managed but in the near future as more wells are brought into productinn the recordkecping workload.w1l he overwhelming ing the Dil and Gas offlce staff.

4. A simple system can be designed to enter the data lint the tribal computer and automate the error-checking task and produce management reports for tribal analysis. This system requires outside programming services to implement.

5. The urgency of the need for an automated Jotnt venture ofl and gas system is such that the Trihn shnuld proceed at nnce with contracting for such pengramming seivices.

SCOPE OF WORK RFQUIREII):

The compiter programmer will be requited to design and program in IBM RPfi-II langunge, programs to process the foll Inwing major proframs:

1. Monthly Input Program:

This program will operate nn input data keyed in to the computer concerning Well Code, Product, Rilantity, Price ur Reveñue, or Expense.

It will create and update well history records stored on magnetic disk. It will check for Input errors and notify the operator. There will be routines programmed for both ofl and gas revenue calculation based on input data and programmed calculation routines,

2. Well History Program:

On demand, this program will access the stored data on the joint venture disk file and print a report on well. production and operating history

by contract and well code.

3. Revenue and Expense Report Program:

Monthly, for each joint venture partriership agreement and for each product, a report will be printed on profitabllity of the venture. It will show by well the reverile and expenses and is intended for tribal management infor- 


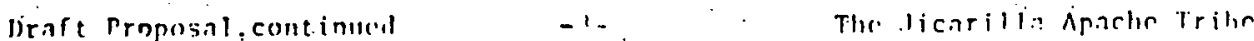

mallon for declistion makills.

4. Revenue Comparison Program:

Monthly, for each joint venture: partner-

ship agreement, a report on earner revenue

and onc on revenuc comparison will he princed.

This report will detail hy contract nimber

oll and gas revenue, tribal royalties, overhead

payments recelved, total earned revenue,

expenses, reserves, and the net enrned revenur.

The program will compare net earned revenue expected to that actilally recelved from the jotnt venture partners, thus al inwing, the Trthe to followup on differences.

SIERIC:S 'TI RE PROCIRED):

The computer programming contractne will he requifur to design a system hased on prelimlnary system specifications developed hy

Frnst \& Ernst in connection with Task 5 of their contract with the

U.S. Department of Energy to develop minerals management procedures for the Jicartlla Apache Tribe.

Ernst Ernst will monltor development of the system design and testing, of the completed system.

The contractor must code programs in IBM RPG-II in a modular fashion for the Trthe's IBM System 3/Model 4 computer. The programs must include a narrative description of routines programmed and al 1 flles accessed.

The contractor will test each prigram to the Trihe's satisfaction and train tribal employes in operation of the computer. Complete documentation of each program will be developed from the user's point of view. All program source listings and documentation will become the property of the Jicarilla Apache Tribe.

The contractor wll provide a specified amount of trouble-shoiting assistance after the system has gone into operation. This assistance wll be included in the contract for services.

CosTS : 
costs:

Est Imated costs for development of this system are as follows:

Total manliours requifed: 450

Contractor's rate: $\$ 20$ per hour

$\$ 9.000 .00$

Triavel and misc: expenses:

$1,000.00$

$\$ 10,000.00$ 
FOOTNOOTES

SECTTIOAN I İI

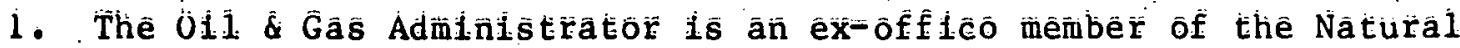

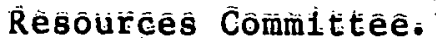

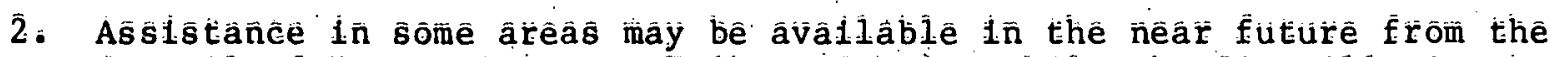

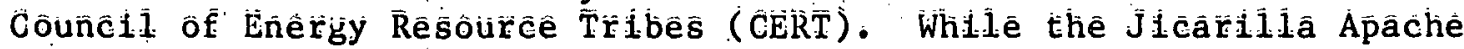

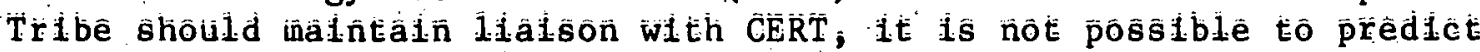

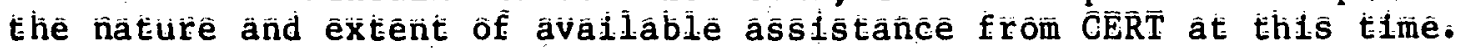

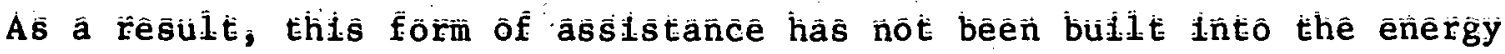
manàgèment strâtègy.

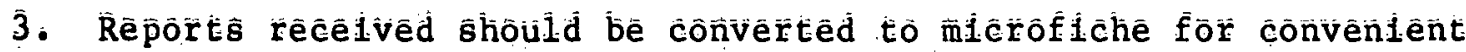

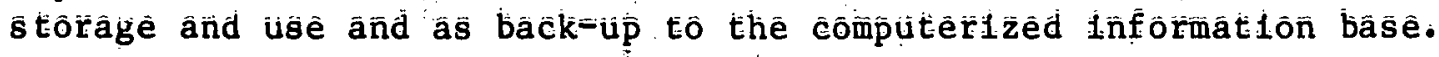


APPENDIX A

LEGAL ANALYSIS OF OIL AND GAS DEVELOPMENT ON THE LAND OF. THE JICARILLA APACHE TRIBE 


\section{PART I}

FEDERAL CONSTRAINTS--

STATUTORY AND REGULATORY

This analysis addresses Federal statutes and regulations pertaining to tribal authority to convey mineral rights and to regulate and tax mineral operations. The organization of the analysis will be as follows: leasing, conveyancing and operations; environmental requirements; civil rights limitations; Federal court jurisdiction; Federal income taxation; and Federal trust obligation.

Section I. Leasing, Conveyancing, and Operations.

A. Tribal Lands--Statutes.

(1) Non-Intercourse Acts--25 U.S.C. Sections 177, 81.

Both tribal and allotted trust lands are subject to statutory constraints on alienation and encumbrance. For tribal lands the source of the constraint is the Indian Trade and Intercourse Act, which forbids any alienation or encumbrance of such lands for any purpose without congressional approval.1/

The Act is applicable to the Jicarilla tribal lands within the bounds of the reservation $2 /$ as well as to all other lands owned by the Jicarilla Tribe, $3 /$ except perhaps lands outside the reservation purchased by the Tribe with unrestricted funds from a non-Federal source. $\underline{4}$ /

Any conveyance of such covered lands in violation of the Act is void. 5 / Even a short-term grazing lease has been considered a conveyance under the Act.6/ As a consequence, the conveyance of minerals in place by deed or lease is certainly within the scope of the Act. Some question exists about whether the Act prohibits a tribe from acting on its own, i.e., without secretarial approval, to develop, produce, and sell its minerals after severance from the land, since this would not constitute the conveyance of an interest in the land itself. Limited authority indicates that such would also be prohibited by the Act. II

In addition, tribal agreeements calling for the tribe's payment of money or other consideration of value or the tribe's granting or obtaining services on tribal lands are void unless approved as prescribed by statute. $\underline{8}$ / In 
Green v. Menominee Tribe, $9 /$ a contract between a licensed trader and a tribe whereby the trader agreed to make available lumbering equipment to the tribe in consideration for compensation was invalidated. Although the full import of this provision is not immediately clear, any contract the tribe enters into which involves tribal lands should comply with the following requirements unless exempted as discussed below under the 1934 Indian Reorganization Act (IRA):

First. The agreement shall be in writing and a duplicate of it delivered to each party.

Second. It shall bear the approval of the. Secretary of the Interior and the Commissioner of Indian Affairs endorsed upon it.

Third. It shall contain the names of all parties in interest, their residence and occupation; and if made with a tribe, by their tribal authorities, the scope of authority and the reason for exercising that authority shall be given specifically.

Fourth. It shall state the time when and place where made, the particular purpose for which made, the special thing or things to be done under it, and if for the collection of money, the basis of the claim, the source from which it is to be collected, the disposition to be made of it when collected, the amount or percentage rate of the fee in all cases; and if any contingent matter or condition constitutes a part of the contract or agreement, it shall be specifically set forth.

Fifth. It shall have a fixed limited time to run, which shall be distinctly stated.10/

\section{(2) Authority to Convey and Contract.}

There are two basic sources of authority for the Jicarilla Apache Tribe to contract with respect to and convey interests in its minerals, particularly its oil and gas. These sources constitute the congressional consent for agreement and disposition required under the above described NonIntercourse Act. First, the Tribe has obtained a charter under section 17 of the 1934 Indian Reorganization Act11/ which empowers the Tribe: (1) to transfer any interest in its property for a period not exceeding 10 years completely independently of Federal supervision; and (2) to conduct business by contract. The second source of authority is the mineral leasing statutes.

\section{(a) Section 17 of the IRA.12/}

It appears clear that pursuant to this provision a tribe could have authority to grant mineral leases and other rights for a period not exceeding 10 years in duration, without Federal supervision, if their charter contains this power.13/ The IRA would likewise appear to authorize independent tribal ventures to develop, produce, and sell their own minerals by contract. However, sales contracts entered into for the severed minerals exceeding the durational limits of 10 years are subject to 
question under the 10-year limit above. Nevertheless, if the tribe has authority to grant someone else the right to develop the minerals, the tribe certainly has the authority to develop the minerals on its own. The Jicarilla charter requires both that transfers conform durationally to Federal statutes and that secretarial consent be obtained. So there is no expansion of tribal authority under the current charter.

\section{(b) Mineral Leasing Acts.}

Although preceded by leasing statues in $1891,14 / 1919,15 / 1924,16 / 1926,17 /$ $1.927,18 /$ the 1938 Tribal Leasing Act is the basis for mineral leasing on most reservations today, including that of the Jicarilla Tribe.19/ The 1938 Act applies. comprehensively to the leasing of tribal minerals and expressly repeals any prior legislation inconsistent with it.20/ However, the authority granted to tribes chartered under the 1934 IRA is preserved in the 1938 Act.21/ The first section of the Act empowers tribes to lease their unallotted lands for mining purposes with the approval of the Secretary of the Interior and the tribe's council or other authorized spokesman. The primary term of such leases may be up to 10 years and so long thereafter as minerals are produced in paying quantities.22/ Section 2 of the Act requires the public offering of oil and/or gas leases either by auction or on sealed bid after notice and advertisement.23/ The statute empowers the Secretary to reject all bids whenever the interests of the Indians will be best served by doing so. If no satisfactory bid is received, or the bidder fails to complete the lease, or the Secretary rejects the highest bid, he may either readvertise or, with the consent of the appropriate tribal officials, negotiate the lease privately.24/ Subsequent sections of the Act prescribe bonding requirements and empower the Secretary to promulgate regulations, to delegate authority to. subordinates, and to approve leases for subsurface storage of oil and gas. $25 /$

\section{(c) Leases Violative of Statute.}

Leases not executed in accordance with Federal legislation are void.26/ It would also appear that administrative acquiescence in practices violating such legislation will not give rise to the defense of estoppel.27/

\section{(d) Summary.}

Under the IRA, the authority to transfer property rights independently is limited to periods of 10 years or less. For oil and gas this limit renders the prospect for transfers of such rights in place unlikely. However, the IRA provides the basis for tribal development and sale of its own oil and gas. Further, under the 1938 Leasing Act, the statutory requirements of public offering, a maximum primary term of 10 years and so long thereafter, and the requirement for Secretarial approval substantially impedes the tribe's ability to determine its affairs for itself. However, the 1938 Leasing Act does provide a more conventional vehicle for disposition of transfer rights which avoids the durational problems under the IRA if the tribe does not desire to exploit independently its oil and gas reserves.28/ 


\author{
B. Allotted Lands--Statutes.29/ \\ C. Current Regulations on $0 i 1$ and Gas Leasing and Operations.
}

(1) Divergence from Regulations.

(a) Secretarial Power to Waive Regulations.

In the regulations the Secretary reserves "the power to waive or make exceptions - . . where permitted by law and the Secretary finds that such waiver or exception is in the best interest of the Indians."30/

\title{
(b) Leases Violative of Regulations.
}

Leases which do not violate legislative prescription and which are approved by the Secretary of the Interior have been held valid even though inconsistent with existing regulations.31/ Such leases were considered an ad hoc suspension or superseding of the inconsistent regulations. $32 /$ However, the Crow Tribe recently challenged certain leases on their lands as invalid since they were in part inconsistent with the regulations and therefore in breach of the Federal trust responsibility. Although the suit appears at least close to settlement, in the settlement offer $33 /$ the Secretary has taken the position that there must be both evidence justifying each waiver and then an explicit waiver of the regulatory provision in order for the waiver to be valid. 34 /

\section{(2) Oil and Gas Lease Offering.}

(a) Leasing Agent.

It is clear that the lessor (i.e., the party granting the oil and gas rights on the tribal lands) is the tribe.35/

\section{(b) Tribal Authorization.}

The first prerequisite to a lease offering under the regulations is authorization by the tribal council or other authorized tribal representative for the particular offering.36/

The charter of the Jicarilla Tribe, last amended in 1960, limits mineral transfers to those durations permitted by Federal law. Additionally it requires that such transfers be approved by the Secretary.37/ As a consequence, no increase in authority is created in the Tribe as a result of the charter.

\section{(c) Forms.}

The regulations provide that leases shall be given on forms specified by the Secretary. $38 /$ 


\section{(d) Lease Sale.}

The regulations set forth below in the text are quite specific in prescribing the procedure for the advertised sale of oil and gas leases. $39 /$

\section{(e) Approval by Secretary.}

The Secretary may either approve or reject the highest bid after the offering, as specified in the regulations pursuant to the 1938 Act.40/ Any modifications in the lease would also be evaluated by the Secretary at this time if not earlier, i.e., at the time of public offering. In any event, this necessary prerequisite of approval has been held conclusive in the absence of fraud or arbitrariness.41/ Proposed regulations published on July 19, 1977, would require that contracts negotiated pursuant to authority that an IRA tribe may have would be submitted to the BIA superintendent prior to approval by the Secretary.42/ If finalized, these regulations would only govern pending adoption of the comprehensive regulations on mineral development proposed earlier in $1977.43 /$ If a tribe has authority under its IRA charter to lease for not more than 10 years as the statute permits, approval should not be required;44/ nevertheless, even under the comprehensive proposed regulations approval appears to be a prerequisite.

\section{(f) Effective Date of Lease.}

The effective date of the oil and gas lease is the date of secretarial approva1. $45 /$

(g) Bonds.

Pursuant to the 1938 Act, the regulations set forth bonding requirements which vary with the size of the leasehold:

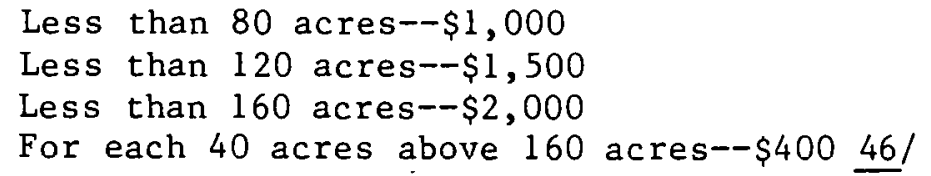

In lieu thereof, lessee may post a bond in the amount of $\$ 75,000$ for nationwide coverage.47/ The right to require an increase in the amount of the bond is expressly reserved. $48 /$

(h) Information Required with Lease Application.

If the prospective lessee is a corporation, the regulations require the submission of substantial information with the application concerning, among other things, its ownership and financial condition.49/

Additionally, either before or after approval of a lease, the superintendent of the reservation is empowered to require any other information deemed necessary to carry out the purpose of the regulations.50/ 


\section{(i) Government Employees.}

The regulations prohibit any Federal government employees from obtaining any interest in mineral leases of tribal property.51/ Additionally, such employees are forbidden from owning stock in corporations that have such interests. $\underline{521}$

\section{(3) Subsurface Storage.}

The regulations pursuant to the 1938 Act permit the Secretary or an authorized representative, with the prior consent of the tribe, to approve leases for subsurface storage of oil and gas regardless of the original source of the production.53/ The storage lease must provide for an adequate fee or rental, or in the case of a mix with original unproduced oil and gas, for a royalty other than that prescribed in the oil and gas lease.54/ Additionally, with prior tribal consent, an oil and gas lease may include the right to store production. This right continues as long as the storage continues and as long thereafter as oil and gas not previously produced are produced in paying quantities.55/ The requirements for application are detailed in the regulations.56/

\section{(4) Prospecting Permits.}

There is no provision in the regulations authorizing the issuance of prospecting permits for oil and gas on tribal lands. However, BIA form 5-145 is used for the granting of such rights. Additionally, the regulations indicate that the nationwide bond, discussed previously, will cover oil and gas prospecting permits as well as leases. $57 /$ So the practice of granting such rights is recognized and does exist.

There should not be a question about the practice since the power to lease has been given by Congress. Also, since the rights granted by a lease include the right to explore for the leased mineral, the separate right to explore can surely be conveyed. If, however, the prospecting permit for oil and gas carries with it an option to lease, then all the requirements for oil and gas leases on tribal property under the 1938 Act should be observed.

\section{(5) Lease Content.}

(a) Minerals Leased.

Under the current oil and gas lease forms which have been drafted pursuant to regulation, 58/ helium gas, carbon dioxide gas, and sulfur gas are included in addition to the oil and gas, as commonly defined.

\section{(b) Acreage Limits.}

The area covered by a lease must be in a compact body and in conformance with the public land survey.59/ Additionally, there is no limit on the number of leases a lessee may obtain, although no oil and gas lease may exceed 2,560 acres except where the rule of approximation applies.60/ With 
the consent of the lessor, the Commissioner may modify the development and production requirements of the leases so that operations and production on one leasehold shall be deemed to satisfy the requirements of the other leases.티

\section{(c) Lease Term.}

Pursuant to specific prescription in the 1938 Act, oil and gas leases may be made for 10 years and so long thereafter as production is obtained in paying quantities.62/ The primary term commences with the secretarial approval of the lease.63/ Although the proposed regulations contain a definition of paying quantities, 64 / the current regulations do not define this term. The requirement of paying quantities appears identical, however, to that in leases of private lands, i.e., the amount necessary to pay a profit over costs of operations and marketing. $65 /$

Leases with a primary term in excess of 10 years have been held void.66/ This durational requirement subjects to considerable doubt the validity of force majeure provisions and shut-in royalty clauses, since these provisions would permit the lease to extend beyond the primary term without paying production. It is, however, not settled whether doctrines applicable to private leases such as "temporary cessation of production"67/ are applicable to oil and gas leases on Indian lands in view of the express and unqualified durational requirement in the 1938 Act. $\underline{68 /}$

\section{(d) Delay Rentals.}

The lessee is required by the regulations to pay an annual rental of $\$ 1.25$ per acre (in advance) beginning on the date of approval.69/ The standard oil and gas lease form currently in use includes the rental provision as a convenant rather than as a special limitation.70/ It has be held that the rental obligation gives rise to a personal debt which cannot be avoided by a subsequent surrender of the lease.71/ Additionally, the rental paid is creditable against any royalty due for the year of payment. 72 I

As will be discussed in more detail below, the regulations73/ and the current lease form permit the Secretary to declare a lease forfeited upon a breach of the lease provisions. It has been held that acceptance of a late rental payment by the reservation agent did not prevent the tribe in question from seeking cancellation of the lease and did not constitute a waiver of the right to claim a forfeiture.74/ However, where the lease does not expressly call for forfeiture, the sanction of termination will probably not be imposed. $\underline{75 /}$

\section{(e) Oil and Gas Royalties.}

The royalty is a minimum of $12-1 / 2$ percent of the value or amount of all oil and gas, natural gasoline, and other hydrocarbons produced and saved, except that used by lessee for development and operation purposes on the lease.76/ Prior to the advertisement of a lease offering, a higher royalty may be set by the Secretary.77/ As a consequence, most, if not all, lease offerings provide for a $16-2 \frac{73}{3}$ percent royalty. 
Value, as defined in the regulations, is calculated on the basis of the highest price paid or offered at the time of production for similar resources produced from the same field.78/ The actual amount realized by the lessee from the sale of production from the leasehold may be deemed merely evidence of value or conclusive evidence of value, at the discretion of the Secretary.79/ Where actual sales or the market in the area is limited, the problem of determining value is especially difficult. For royalty purposes, value of substances like natural gas, which are derived by the application of treatment processes, is determined by subtracting from the value of the marketable product two-thirds thereof, unless a different amount is set by the Secretary as a reasonable allowance for such processing or manufacturing. The royalty fraction is then applied against the resulting amount, as the value of products therefrom such as residue gas, natural gas, propane, butane, etc., or against the value of the raw gas or casinghead gas, whichever is greater.80/ Additionally, customers of usage may justify other variations in the computation of royalty despite the lack of express statutory or regulatory authorization.81/

If lessee produces gas in excess of his operational needs, lessor is entitled to use sufficient amount of such excess without cost for schools and other tribal buildings.82/ Lessor, however, must make the connections at its own expense. $83 /$

\section{(f) Payment of Rental and Royalty.}

Rental and royalty, except the first payment of the rental, should be paid to the superintendent of the reservation through the USGS supervisor for the benefit of lessors. Rentals are due on or before the anniversary of the date of approval, and royalties are due on or before the last day on the calendar month following calendar month for which such payment is to be made.84/ First-year rentals should be sent directly to the superintendent at the time of filing the lease.85/ Thereafter, payments sent through the supervisor to the superintendent, should be accompanied by a statement in triplicate showing the items of rental and/or royalty intended to be covered.86/ Proposed regulations promulgated on July 19, 1977, relieve the supervisor of the responsibility for collecting and distributing funds due on contracts involving profit sharing provisions.87/ These regulations are issued pending final adoption of the new comprehensive proposed regulations published earlier in 1977.

\section{(g) Changes in Leases.}

The current lease form precludes unilateral changes in rates of royalty and rental without consent of the parties. Additionally, the regulations provide that regulatory changes made after approval of the lease may not change the term of the lease, royalty and rental, and acreage.88/ This limitation is supported by case law holding unilaterial changes in the above respects invalid. 89 / 


\section{(h) Indian Training and Employment.}

No provision is made in the current regulations for Indian training and employment. However, consideration should be given to the inclusion of such a requirement in the lease prior to the lease offering. No formal waiver of the regulations should be necessary, since such a provision should not be inconsistent with the current regulations. $90 /$

\section{(6) Operations.}

(a) Federal Operating Regulations.

The 1938 Act,91/ the regulations, $92 /$ and the current lease form make all lessee operations subject to the Federal operating regulations applicable to the public domain and other lands controlled by the United States.93/ These regulations are administered under the direction of the U.S. Geological Survey.94/ Proposed regulations published on July 19, 1977, would make applicable the regulations of both the USGS and title 25 of the C.F.R. which govern operations to the mineral contracts of IRA tribes to the extent not inconsistent therewith.95/ Nevertheless, the following regulations apply specially to oil and gas operations on tribal lands.

\section{(b) The Supervisor.}

Under the current regulations, the USGS supervisor is given authority to direct and supervise operations and to furnish technical information and advice, to ascertain and record the amount and value of production, and to determine and record rentals and royalties due and paid.96/ Proposed regulations published on July 19, 1977, would, if finalized, relieve the supervisor of the obligation to perform operational cost accounting functions, or collect or distribute funds resulting from any profit sharing agreements, or enforce contractual provisions beyond the scope of services normally rendered in administering oil and gas leases.97/ These regulations were proposed pending the finalization of the comprehensive regulations discussed below and in response to an increase in the numbers of agreements which do not take a traditional form and which involve tribes organized and chartered under the Indian Reorganization Act.

\section{(c) Permission to Commence Operations.}

The lessee may not commence operations until the lease has been approved.98/ Additionally, lessee must obtain the written permission of the Supervisor before starting operations.99/

\section{(d) Diligence and Prevention of Waste.}

The regulations require in specific terms that the lessee exercise diligence and prevent waste in its operations. The regulatory provision is. set out in full in the notes below.100/

\section{(e) Division Orders.}

A purchaser of oil from the lessee is not allowed to accept or run oil from tribal lands until after the approval by the USGS of a division order which 
must show that lessee has a regularly approved and existing lease.101/ The division order may provide that the oil purchaser shall make payments directly to the superintendent, but it cannot relieve the lessee of the obligation to make such payments when due.102/ When the lessee runs its own oil, it must execute an intracompany division order which is approved by the supervisor.103/ The supervisor may at any time cancel a division order and stop the run of a lessee who is violating provisions of the lease or the regulations.

The regulations require the lessee or a representative to be present when the oil is gauged and records are made of temperature, gravity, and impurities, which analyses are to be made at the pipeline, except for the lowest gauge.104/ Lessee is responsible for the correctness of the above and failure to so perform could subject the division order to cancellation.105/

\section{(f) Inspections.}

The regulations clearly provide that the tribe, through its agents, as well as any authorized representative of the Department of the Interior, may enter "from time to time" on the leasehold to inspect.106/ Because the regulations are made a part of the leases, lessee agrees to allow the inspections and to keep accounts of its operations and reports as required by the operation regulations.107/

Unfortunately, the regulations expressly empower only those officers of the department who are instructed in writing by the Secretary or who are authorized by the regulations to inspect lessee's books and records.108/ To such officers, however, the books and records must be open at all times.109/

The tribe should insist on inclusion in the lease of a complete right to inspect. This inclusion should be made before the lease offering and should be supported by a statement from appropriate officials in Interior setting forth the reasons for this expansion of tribal authority. Such a statement is recommended so as to avoid any later question concerning the validity of the added lease provision on the grounds that the regulations were invalidly modified.110/

\section{(g) Restrictions on Operations.}

The Secretary reserved in the regulations the power to impose such additional restrictions on the time of drilling and on production as the resource and the interest of the lessor require.111/ The Secretary may take into account Federal and State laws and regulations, operator agreements, and the wishes of tribal authorities in imposing such restrictions.112/

\section{(h) Unit Operations.}

With prior consent of the tribe, the Secretary may subject tribal leases to cooperative or unit development. The current lease form additionally 
consents to such unit operations when approved by the Secretary and approved by a majority of the operating interests involved.113/

\section{(7) Assignments.}

Leases or any interest therein may be assigned or transferred only with the approval of the Secretary.114/ Covered by this limit are assignments, subleases, and all other direct and indirect transfers of operating rights.

The regulations appear to allow only those transfers in which lessee disposes of either its whole interest or any undivided interest in the whole leasehold.116/ However, the current tribal lease form provides that if the lease is subdivided by the assignment of an entire interest in any part of the leasehold, each portion shall be considered a separate lease under the terms and conditions of the original lease. There is some indication that the Department of the Interior will approve an assignment of the entire interest in a portion of the lease, i.e., a subdivision of the lease, but not an individual interest in a subdivided portion.117/

In order to procure the approval of the Secretary, the assignee must qualify to hold the lease and must furnish a satisfactory bond to assure the faithful performance of the provisions in the lease and regulations.118/ The instrument of assignment and any stipulations modifying the terms of existing leases, which stipulations are also subject to the approval of the Secretary, are required to be filed with the superintendent within 30 days after the date of execution of the assignment.

The creation and assignment of overriding royalties and production payments are permitted by the regulations without approval as a prerequisite.119/ None of the obligations of the lessee and assignee may be modified by such transactions, however. Additionally, the existence of such interests outstanding will not be considered justification for the approval of the abandonment of any we11.120/ Agreements creating such interests need not be filed with the superintendent unless they are incorporated in assignments or other instruments required to be filed by the regulations. $121 /$

\section{(8) Surrender of Lease.}

The regulations provide that a lessee may surrender a lease or any part thereof with the approval of the Secretary after meeting the following requirements: an application therefor to the superintendent, the payment of a $\$ 1.00$ surrender fee at the time of application, the payment of all royalties and rentals due at the time, a showing that full provision has been made for the conservation and protection of the property and that all wells have been properly abandoned, the filing of a recorded release of the acreage covered by the application if the lease has been recorded, and a surrender of the lease.122/ All required fees and papers must be in the mail or received on or before the date on which rents and royalties become due in order for lessee to be relieved from liability for the payment of such rents and royalties. Lessee is not currently entitled to either a refund for any advanced rental or a release of liability for due rentals and royalties.123/ 
In the event that oil or gas is being drained from the leasehold by a well off the leasehold, the lease may only be surrendered on such terms as the Secretary deems reasonable and equitable.124/ Additionally, if there has been a contest with respect to a lease, the approved, disapproved, or canceled portions thereof will be held in the office of the superintendent for 5 days after the decision on the contest has been promulgated. Such lease will not be delivered, if within the 5 days a motion for review and reconsideration is filed, until such motion is decided by the Department of the Interior.125/

\section{(9) Removal of Equipment.}

When the lease expires or is surrendered, the machinery necessary to operate the property belongs to the lessee.126/ However, removal may take place only after the Secretary determines that the leasehold is in satisfactory condition. $127 /$

The current lease form provides for lessee's removal of all buildings, structures, casing material, and/or equipment placed on the leasehold for the purpose of development and operation except that necessary for the continued operation of wells which are producing or capable of production in paying quantities at the time of surrender or termination. Such removal, however, must take place within 90 days after the termination or lessee will probably lose the right to remove. such property.128/

Enforcement or Cancellation of Lease for Violations.

A violation of the provisions of the lease, the operating regulations, the special regulations relating to operations on tribal lands, orders of the reservation superintendent, or orders of the supervisor shall subject the lease to cancellation and/or lessee to a penalty of $\$ 500$ per day for each day of such violation.129/ The regulations provide, however, that lessee is entitled to notice which specifies the term of the lease, regulation, or order violated and a hearing 30 days after such notice.130/ The hearing is conducted by the supervisor, whose findings are conclusive unless an appeal has been taken to the Secretary within 30 days after notice of the supervisor's decision.131/ In such case, according to the regulations, the decision of the Secretary is final.132/ Upon a decision favorable to lessor, the regulations provide that lessor is entitled to immediate possession of the leasehold.133/ Proposed regulations published on July 19,1977 , relieve the supervisor of the responsibility for enforcement of contract provisions which are beyond the scope of services traditionally provided by him.134/ These regulations are issued pending final adoption of the new, comprehensive proposed regulations published earlier in 1977 .

It may be that despite the prescription in the regulations the decision of the Secretary is not final in view of a recent Federal district court decision affirmed by the Ninth Circuit which held such contrary to due process. $135 /$

In any event, if the tribe believes that a lease term, order, or regulation 
has been violated, the tribe must persuade the Department of the Interior of such if cancellation proceedings are to be initiated under the current regulations. The burden of proof to establish such violation in an administrative hearing is probably the settled "preponderance of the evidence" standard applied in most administrative proceedings.136/ This burden is defined as "evidence sufficient to be more convincing to the trier than the opposing evidence."137/ The hearing prescribed in the regulations must meet the requirements of procedural due process $138 /$ with at least notice, opportunity to present evidence and to counter or rebut adverse evidence, the right to counsel, and with the decision based only on the evidence introduced.139/ In addition, a record may well be required.140/ The burden of proof would appear to be on the proponent of the order, i.e., the party seeking cancellation.141/

\section{(11) Indian Regulation.}

If an IRA chartered tribe is to regulate the lessee's operations, under the current regulations the tribe must include the right to do so in the leasing contract. Then, inasmuch as such is contrary to the regulations, a formal waiver of the regulations must be obtained together with a justification therefor being provided by appropriate Interior of ficials. If the stop-gap proposed regulation is adopted, then the formal waiver procedure appears unnecessary although the applicability of tribal law to operations probably must still be agreed to in the contract. Additionally, if the contract is potentially to run for more than 10 years, then the public sale requirements of the 1938 Tribal Leasing Act must be complied with.

\section{Proposed Regulations on Tribal Oil and Gas Contracting and Operation.}

\section{(1) In General.}

\section{(a) Purpose.}

On April 5, 1977, proposed regulations were promulgated to update and clarify the current regulations in "acknowledgement of the increasing desire of Indian mineral owners . . to exercise greater responsibility in the development and management of their minerals and natural resources." $142 /$ The preface to the portion of the proposed regulations relating to oil and gas development acknowledges the prospect of greater Indian involvement in the development of oil and gas reserves but recognizes the limits, discussed above, imposed by statute on such activities:

- . Certain so-called "organized" tribes may utilize virtually any method they choose while most other tribes must utilize a competitive bid procedure. It is not necessary, however, to conduct these bids on a set royalty basis with the award going to the bidder who offers the largest bonus. Bidders may be allowed to compete on such terms as rental, royalties and other returns to be paid on the oil and gas produced. The proposed Part 182 (relating to oil and gas) provides that the advertisement shall 
specify any terms requested by the Indian mineral owner. The proposed regulations are also intended to allow interested parties the necessary flexibility to capitalize their ventures. Accordingly, overriding royalties and assignments, including assignments of separate horizons, are expressly permitted under certain conditions that are designed to reflect the Department's continuing trust responsibility to Indian mineral owners.143/

\section{(b) General Summary.}

As described above, there are two general statutory vehicles for oil and gas development and disposition on tribal lands: the Indian Reorganization Act avenue, which is restricted to dispositions of not more than 10 years; and the 1938 Mineral Leasing Act, which limits the primary term to not more than 10 years but allows the interest to continue on so long as production is obtained in paying quantities. Also, the 1938 Act requires that oil and gas leases be publicly advertised and sold as well as approved by the Secretary.144/ In addition, the position of the Secretary of the Interior on the procedure that must be followed to obtain a valid deviation from the regulations should be recalled.145/

The proposed regulations clearly acknowledge and exploit the above two avenues of conveyance and, additionally, facilitate the achievement under both approaches by tribal lessors or owners of agreements which may diverge from the regulations and/or the orthodox forms of transfer used so of ten in the past. Tribal legislation and contract are the two means by which the proposed regulations provide for the tribal accomplishment of such ends. Tribal legislation is contemplated in the regulations as permitting the tribe to impose and enforce its own development and operation standards; the latter can be considerably broader in scope within, of course, the statutory limits discussed above.

Another distinguishing characteristic of the proposed regulations is the use of the word "contract" in place of the word "lease," an attempt to cover all forms of rights that the tribe may dispose of pursuant to the proposed regulations. There are still some references, however, to "lease," "lessor," "lessee," and "leased premises," but these references would appear inadvertent except where expressly distinguished from "contract."

\section{(2) Disposition of 0 il and Gas Rights.}

\section{(a) General Observations.}

Although there are several specific provisions in the regulations which cause questions of one sort or another, two general questions should be highlighted at this point in the discussion. First, the proposed regulations clearly require secretarial approval as a prerequisite to validity of all contracts.146/ Although the Department of the Interior may have the power under its trust authority to so regulate, it seems clear 
that if the charter issued under section 17 of the Indian Reorganization

Act permits tribal conveyances for periods of not more than 10 years, then such conveyances may be made independent of any departmental involvement.147/. Although the Jicarilla tribal charter may be amended with secretarial approval, it presently provides no additional authority in the Tribe to convey independently such interests in tribal minerals or lands. Secondly, the proposed regulations talk broadly in terms of the procedures to be followed for "organized" tribes and the procedures for unorganizd tribes. However, the proposed regulations fail to acknowledge clearly the fact that an "organized" tribe may have to utilize the procedures available to the unorganized tribe, i.e., the 1938 Leasing Act, if the Indian Reorganization Act under which the tribe is "organized" does not permit what the particular tribe wants or needs, e.g., a transfer for more than 10 years. In any event, there should be no difficulty or problem with an "organized" tribe utilizing the procedures available to an unorganized tribe under the 1938 Act.148/

\section{(b) Contracting Agent.}

As under the current regulations, the leasing agent or lessor under the proposed regulations is the tribe.149/ The Secretary is expressly precluded from offering leases or interests on tribal oil and gas rights without a request to do so from the tribe.150/

\section{(c) Contract Sale.}

The tribe is authorized in the proposed regulations to either negotiate contracts, award them through competitive bidding, or combine both methods.151/ The tribe may also request the Secretary to undertake the preparation, advertisement, negotiation, and/or award of such contract on its behalf.152/ It appears that, under the proposed regulations, the tribe may request the secretary to do less than the entire process as well. In such event the proposed regulations require the Secretary to carry out such request.153/ If the Secretary is requested to advertise and award a contract, the proposed regulations make specific provision for the procedure to be followed.154/

In any event, the proposed regulations indicate that there are no restrictions on the terms of contract negotiated or offered by the tribe other than that of duration, that the contracts must provide a fair return, and that it must be in writing and approved by the Secretary.155/

Under the proposed regulations, much more flexibility is given to the tribe to negotiate, to offer for public sale in the standard form, to offer for public sale in a special form, or to negotiate and then offer for public sale contracts on its oil and gas lands. Since the tribe can request the Secretary to undertake the public sale, if the tribe needs or wants a unique contract but must comply with the public sale requirements of the 1938 Act because of the duration of the contract, the proposed regulations appear to permit this without having to obtain a waiver of the regulations as currently appears required.156/ 


\section{(d) Technical Assistance.}

The tribe is encouraged in the proposed regulations to consult with the Area Director157/ during negotiations of an oil and gas contract.158/ In addition, the tribes are invited to seek technical or other advice or assistance regarding development of minerals from the superintendent or the USGS supervisor who "shall provide such assistance upon request consistent with his authority." $159 /$ This latter provision is troublesome in that it might be read as prescribing such assistance only during the development stage of operations rather than during the negotiations or any other stage involving development matters.

\section{(e) Secretarial Approval.}

Prerequisite to validity of a contract is approval of the Secretary.160/ The proposed regulations provide that if the following three conditions are met approval will be given: (1) the contract provides fair and reasonable remuneration to the tribe; (2) the contract benefits outweigh the adverse cultural and environmental impacts; and (3) the contract complies with applicable Federal law and regulations and tribal law where tribal law is consistent with Federal law.

\section{(f) Effective Date of Contract.}

As contrasted with the current regulations, the proposed regulations do not express the time of commencement of the lease. It may be that, as a consequence, the effective date of the lease is the date of execution rather than the date of approval.161/

\section{(g) Bonds.}

The requirements for bonding are increased in the proposed regulations, set forth below in the notes.162/

(h) Information with Contract.

The proposed regulations perpetuate the requirements for information concerning transferee as a prerequisite to approval of the contract.163/

\section{(i) Fees.}

The proposed regulations impose a file fee of $\$ 25.00$ for all contracts. $164 /$

\section{(3) Subsurface Storage.}

The proposed regulations appear to make provision for the granting of subsurface storage rights which are identical to those in the current regulations.165/ 


\section{(4) Prospecting Permits.}

As contrasted with the current regulations, the proposed regulations make express provision for geological and geophysical prospecting permits.166/ Prior consent of the tribe must be obtained; the permit must state the area to be explored, the term of the contract, and the consideration therefor; and the permittee is not given any preference for development and production rights.167/ Applications for prospecting permits, accompanied by the plan of such operations, may be made to the superintendent or to the tribe according to the proposed regulations.168/

The contract must be in a form approved by the Secretary, $169 /$ although the proposed regulations authorize the tribe to negotiate its own prospecting contract or to follow the procedures outlined above for awarding contracts for the oil and gas rights.170/ Such contracts must be approved by the Secretary, 171/ the information requirements described above necessarily apply,172/ and the Secretary has discretion to require a bond.173/ In addition, a filing fee of $\$ 25.00$ is imposed.174/

\section{(5) Contract Content.}

\section{(a) Covered Substances.}

A contract may cover oil or gas or both under the proposed regulations.175/ Oil is defined therein as, "any liquid hydrocarbon substance which occurs naturally in the earth, including drip gasoline or other natural condensates recovered from gas, without resort to manufacturing process." $176 /$ Gas is defined therein as "any fluid, either combustible or noncombustible, which is produced from a natural state from the earth and which maintains a gaseous or rarified state at ordinary temperature and pressure conditions." $177 /$

\section{(b) Acreage Limits.}

The proposed regulations contain no restriction on the amount of acreage covered by any one oil and/or gas contract.

\section{(c) Term of Contract.}

Ten years and so long thereafter as oil and gas are produced in paying quantities is the maximuln duration set in the proposed regulations unless a longer period is permitted or a shorter period required by law.178/ The proposed regulations then provide that the term of any contract entered into by the exercise of an option shall be measured from the date of the exercise of the option.179/ This certainly would give flexibility under the 10-year durational 1imit for transfers by section 17 organized tribes, because a prospective investor might be considerably more interested in making an investment if it has a longer period to recover the investment. Nevertheless, it is doubtful whether this provision would survive a challenge, since a contract for 10 years with an option or successive options clearly gives the transferee rights in the property for the whole period including the option periods. 
(d) Paying Quantities.

The term is now expressly defined in the regulations as:

Where a mining contract specifies a term of years and "as long thereafter as minerals are produced in paying quantities" or similar phrase, the term "paying quantities" shall mean:

(1) That quantity of recovered minerals which produces, during the fiscal year of the contract, an after-tax profit to the operator, over and above the total cost of: extraction, processing, and handling to the point of sale; all rents and royalties paid under the contract; all salaries and expenses incident to such extraction, processing, and handling; all taxes incident thereto; all depreciation of salvageable production equipment; all administrative expenses attributable, such as business licenses, repair of equipment, and transportation; and also,

(2) That quantity of minerals which produces sufficient income so that a reasonably prudent operator would continue to operate in a diligent manner for the purpose of making a profit from the subject operation and not merely for speculation.180/

(e) "Savings" Provision.

The proposed regulations expressly provide cessation of production, force majeure, and drilling operations rights for the contract transferee.181/ All three provisions are subject to some question of validity due to unqualified maximum duration set by statute.182/

\section{(f) Delay Rental.}

A lessee is required to pay in advance $\$ 2.00$ per acre per year as delay rental. As contrasted with the current regulations, the proposed regulations provide that the rental shall not be a credit against production royalty.184/ Assuming no activity excusing delay rentals, express provision is made for termination of the lease or contract if delay rental is not paid on or before the due date.185/

\section{(g) Royalties.}

A royalty of $16-2 / 3$ percent of value is prescribed as the royalty unless "otherwise provided by the Secretary . . "186/ The proposed regulations provide a definition of "value" against which the royalty percent is applied.187/

\section{(h) Minimum Royalty.}

A minimum royalty of $\$ 2.50$ per acre per year, creditable against production royalty for the year, is also provided for.188/ The proposed regulations indicate that on unitized leases, the minimum royalty is paid only on participating acreage.189/ It is not clear whether the minimum royalty is 
payable in a year of no production; however, the qualification for nonunitized property would not seem to have much rationality if this were not the case.

\section{(i) Payment of Rental and Royalty.}

The provisions for payment are similar to those in the current regulations. $190 /$ Additionally, provision is made for the operator's continued liability for royalty payments despite a gas or oil purchaser's promise to pay. $191 /$

\section{(j) Free Gas.}

Provision is made in the proposed regulations, just as in the current regulations, for the lessor tribes entitlement to free gas under limited circumstances.192/

(k) Indian Training and Employment.

Although no provision is made in the proposed regulations for Indian training and employment, consideration should be given to the inclusion of some requirement to this effect in the contract prior to the offering if the contract must be publicly offered.

\section{(6) Operations.}

(a) Tribal Laws.

The proposed regulations make it clear that tribal law including the Constitution, by-laws, charter; ordinances, and resolutions will supersede these proposed regulations in title $25 \mathrm{C} . \mathrm{F} . \mathrm{R}$. in controlling development and operations on tribal lands if such tribal laws provide protection at least as stringent as that provided in the Federal regulations.193/ The Federal law and regulations, however, govern to the extent not superseded by tribal law if "the validity of the contract depends upon the approval of the Secretary of the Interior."194/ The proposed regulations do not appear to permit tribal law to supersede the regulations of the U.S. Geological Survey, discussed immediately below.

\section{(b) Regulations of U.S. Geological Survey.}

The regulations in title $30 \mathrm{C} . \mathrm{F} . \mathrm{R}_{\text {., }}$ section 221 are made applicable to the extent not superseded by the agreement in question or the proposed regulations.195/ It might be argued that tribal law, by superseding the proposed regulations, i.e., those in title 25 , section 182 , supersedes those of the USGS since tribal law has priority over the proposed regulations which have priority over those of the USGS. However, to accomplish such priority it is necessary to provide for it in the lease or contract at least by incorporating such tribal laws as requirements or provisions of the agreement.195a/ 


\section{(c) Authority of Supervisor.}

The USGS area supervisor is authorized to approve, supervise, and direct operations under contracts governed by the proposed regulations.196/ As a consequence, such authority does not extend to operations governed by tribal law. However, the supervisor is responsible for reviewing and reporting to the Secretary his recommendations on proposed oil and gas contracts.197/

Additionally, the supervisor is authorized to furnish both the Secretary and the tribe scientific and technical information and advice.198/ The proposed regulations at another point invite the tribe to seek technical advice from the supervisor concerning development of minerals and require him to provide such consistent with his authority.199/

Authority is also given to ascertain and record the amount and value of production and to determine and record rentals due and paid.200/ The proposed regulations make it clear that the supervisor is not responsible for monitoring, accounting for, and collecting funds on contracts involving profit-sharing arrangements or methods of payment other than percentage royalties. $201 /$

\section{(d) Inspections.}

Operators are required to allow both tribal officials and appropriate Interior officials to inspect both the premises and their books and records.202/ Additionally, operators are required to make all reports necessitated by the contract and the regulations.203/ This proposed right of tribal officials to inspect the books and records of the operators is not set forth in the current regulations.

\section{(e) Secretarial Restrictions on Operations.}

The Secretary is authorized generally to impose any restrictions necessary for the protection of Indian-owned natural resources.204/ Additionally, for market reasons the Secretary is authorized to suspend production during the 10-year primary term with the consent of the tribe.205/ Such suspension may be requested by the operator but will not relleve him of the rental and minimum royalty obligation and in addition gives rise to a $\$ 2.50$ per acre annual shut-in royalty requirement which must be paid in advance.206/ With the consent of the tribe, the Secretary may also authorize suspension of operations so that the operator might commence drilling or reworking.207/ The operator must commence such drilling or reworking within 60 days after the suspension and continue such thereafter with reasonable diligence. $208 /$ Such suspension does not relieve the operator of liability for any rental, minimum royalty, or other obligation due under the contract.․ㅣ/

\section{(f) Unitization.}

The proposed regulations permit the Secretary, with the consent of the tribe, to approve or require that the contract areas be included in unit agreements, drilling agreements, and well spacing or development 
programs.210/ All documents relating thereto must be filed with the Secretary, including any application therefor with a full description of the concerned lands.211/

\section{(7) Assignments.}

The proposed regulations make provision for assignments of both operating and nonoperating rights identical to those in the current regulations except that assignment of separate horizons and subdivisions of the contract area are also permitted.212/ In addition, the superintendent is authorized to approve drilling contracts with the condition that such approval does not bind the Department of the Interior to approve subsequent assignments.213/ The proposed regulations note that such "approval merely authorizes entry" on the contract area for the purpose of operations.214/

\section{(8) Surrender.}

Provision is not made in the proposed regulations for surrender by the operator of his rights under the contract. The option to surrender, however, could certainly be bargained for as a right in a contract.

(9) Enforcement and Cancellation of the Contract.

\section{(a) In Genera1.}

In addition to delinquent rental payments, which effect an automatic termination of the contract,215/ the proposed regulations provide for two alternative avenues of enforcement of the law and regulations, the contract, the requirements of any exploration or drilling plan, or the orders of the supervisor.216/ These two depend on whether the noncompliance immediately threatens the environment or the mineral resources.217/

(b) Noncompliance Presents No Immediate Threat.

If the supervisor determines that an operator has failed to comply with the law or regulations, the contract, the requirements of an exploration or, drilling plan, or the orders of the supervisor, and if such noncompliance does not present an immediate threat of serious damage to the environment or other natural resource, the supervisor is required to serve notice of noncompliance upon the permittee or operator in person or by mail.218/. The notice must specify the deficiency and the action necessary to correct it and the time limit for compliance.219/ The permittee or operator is required to submit a report when the compliance has been corrected.220/ If the latter fails to make correction or to initiate an appeal pursuant to title 30 C.F.R., section 290, then the supervisor may suspend his operations or initiate action for cancellation of the contract and forfeiture of the bond.221/ No prescription is made in the proposed regulations for the cancellation action.

\section{(c) Noncompliance Presents Immediate Threat.}

If, in the judgment of the supervisor, the noncompliance presents an

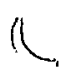


immediate threat in the above respects, the Supervisor must order an immediate cessation of such activities.222/ The permittee or operator then may appeal as prescribed above. However, compliance is required during the appeal unless the appeal officer orders otherwise and an adequate bond is posted.223/

\section{(d) Complaints of and Consultation with the Tribe.}

The proposed regulations require the supervisor to investigate all claims of the tribe concerning the permittee's or operator's failure to comply in the above respects.224/ The supervisor is also required to consult with the superintendent and with the tribe if possible, prior to taking any action described hereinabove.225/

\section{(e) Remedies of the Tribe.}

The proposed regulations make it clear that remedies available to the tribe pursuant to contract or otherwise are not superseded by such regulations. $226 /$

\section{(f) Summary.}

The latter provision described immediately above allows the tribe, through contractual provision and pursuant to the powers of the tribe described below in Part III, to prescribe in the contract the remedies for failure to perform. Additionally, the proposed regulations indicate that such. will be enforced by the Department of the Interior. As noted below, the tribe may also enforce its contracts in State court and Federal court where the jurisdictional prerequisites are met. If this avenue is considered advantageous, the contract should incorporate the tribal law and/or Federal law as part of the contract itself. Alternatively, the tribe may well have authority to enforce its laws independently in its own court system as discussed below in Part III, Section I on Tribal Authority. These laws, however, would probably be preempted by the proposed regulations if the latter are finalized to the extent that tribal law is less stringent than the Federal law and regulations.227/

As proposed, the permittee or operator would appear to have the burden to pursuade the appeals officer that the notice of noncompliance together with its order to correct or suspend operations lacks merit.228/ If the permittee or operator fails to make a timely appeal and $\overline{\text { or }}$ fails to comply, then the burden appears to rest on the supervisor to initiate and prosecute an action for cancellation of the contract and forfeiture of the bond. In any event, the requirement that the supervisor investigate any claims made by the tribe of violation and the broad right of inspection in the proposed regulations, as contrasted with the current regulations, give the tribe a much stronger basis for overseeing the operations on its lands.

Section II. Federal Environmental Laws.

A. National Environmental Policy Act of $1969.229 /$

(1) In Genera1. 
Although the National Environmental Policy Act (NEPA) has had a substantial effect on mineral development in this country, one author has recently said that "it can be written off as 'a paper tiger." $230 /$ After a very broad statement of purpose,231/ the Act sets forth a prescription for the Federal Government to pursue six specified goals using "practical means": (1) that it perform its responsibilities as trustee of the environment; (2) that it assure for Americans livable surroundings; (3) that it attain the widest beneficial use of the environment without undesirable consequences; (4) that it preserve our national heritage; (5) that it achieve a balance between population and resource use which permits a wide sharing of life's amenities; and (6) that it enhance the quality of renewable resources and attain maximum recycling of depletable resources.232/ Despite the substantive import of these goals, the courts have not chosen to enforce them as duties imposed by Congress on the Federal Government.233/ It is rather the second section of NEPA which contains duties imposed on the Federal Government. The most significant of these for purposes of mineral development on Indian lands is that one which requires that all agencies:

(c) include in every recommendation or report on proposals for legislation and other major Federal actions significantly affecting the quality of the human environment, a detailed statement by the responsible official on--

(i) The environmental impact of the proposed action,

(ii) any adverse environmental effects which cannot be avoided should the proposal be implemented,

(iii) alternatives to the proposed action,

(iv) the relationship between the local short-term uses of man's environment and the maintenance and enhancement of long-term productivity, and

(v) any irreversible and irretrievable commitments or resources which would be involved in the proposed action should it be implemented.234/

The types of Federal action to which this section is applicable would include: (1) recommendations for legislative action; (2) new or continuing Federal projects involving Federal funds or a Federal license or approval; and (3) the making or modification of Federal regulations or other administrative action.235/ The agency proposing legislation or other action before preparing a statement is required to consult with any agency having jurisdiction over and expertise with respect to the environmental impact involved.236/ Then this statement, known as an Environmental Impact Statement (EIS), is prepared and submitted to the interested Federal, State, and local agencies together with the proposal for review.237/ The balance of the Act requires a review of all Federal agencies to determine any obstacle to full compliance with the Act,238/ the reconciliation of 
existing obligations of the Federal agencies with the Act,239/ and the creation of the Council on Environmental Quality (CEQ) and the investment of it with limited authority to oversee the functioning of the Act.240/ Pursuant to the mandate of an executive order,241/ the CEQ has promulgated guidelines to aid in the preparation of environmental impact statements.242/

(2) "Major Federal Action.... Significant Effect."

The question of "major Federal action" arose in the context of Department of the Interior approval of a Tesuque Pueblo long-term lease to private developers of a 1,300-acre tract of land with options on another 5,400 acres. The developers planned to establish a small city. The supervisor approved the lease pursuant to the regulations in title $25 \mathrm{C} . \mathrm{F}$.R. without filing an EIS. Nearby landowners filed suit claiming the secretarial approval to be a "major Federal action" and therefore invalid without an EIS. The Tenth Circuit in Davis v. Morton243/ agreed. Thus, it might fairly be concluded that the secretarial approval of any mineral lease would constitute "major Federal action."244/

The significant effect factor is the more difficult of these two criteria to apply. It has been concluded that an exploration permit in a National Forest did not involve such an effect.245/ The decision that an EIS was not required was the result of preliminary consultation and review by the concerned agencies as required by NEPA and the preparation of an Environmental Analysis. Report. On the other hand, the Bureau of Land Management (BLM) grazing leases under the Taylor Grazing Act246/ have been held to "significantly affect" the environment and thus to require an EIS.247/ It seems clear that coal leases on tribal lands would require an EIS. $248 /$ However, there is no case law to indicate that secretarial approval of an oil and gas lease or contract on tribal lands would require the preparation of an EIS. It is reported that Federal land management agencies have often determined that onshore oil and gas development does not require more than the preparation of the pre-EIS evaluation.249/ This position is based at least in part on the fact that potential adverse impacts of such operations are considered and confronted in the regulatory drilling plan requirement.250/ Nevertheless, in view of the potential for harm to the surface and subsurface, in addition to the normal physical impact of such operations, an EIS may be found to be a prerequisite to valid secretarial approval of oil and/or gas leases or contracts on tribal lands.

\section{(3) Indian Operations.}

It has not yet been decided whether NEPA applies to projects conducted by Indians without any involvement of the Federal Government. However, activities by Indians without Federal involvement should not constitute "major Federal action" simply because of the lack of Federal involvement. Certainly, for constitutional purposes, tribal governmental activities are not considered to be Federal actions.251/ For tax purposes Indians and Indian property are no longer considered instrumentalities of the Federal Government.252/ It would seem, therefore, arbitrary to attribute tribal 
operations to the Federal Government for purposes of NEPA.

If, however, the Indians enter into contracts which require secretarial approval under the Indian Intercourse Act dealing with contracts with tribes or Indians, then perhaps an EIS would be required if the other requirements of NEPA are satisfied.253/

\section{B. Clean Air Act.254/}

(1) In Genera1.

Title I of the Clean Air Act of 1963,255/ as amended in 1965,256/1967,257/ $1970,258 /$ and most recently in $1977,259 /$ contains the core of the air pollution program with its constraints on emissions from stationary sources and ambient pollutants. There are basically three goals of Congress in its enactment of this air pollution legislation: (1) the achievement of a level of ambient air quality necessary to protect the public health by 1975; (2) the achievement within a "reasonable" time of a level of ambient air quality which avoids any adverse effects on any environmental, man-made, or aesthetic process; and (3) the maintenance of existing nonpolluted air quality.260/

\section{(2) Regulatory Plan.}

\section{(a) Air Quality Control Regions.}

The Administrator of the U.S. Environmental Protection. Agency (EPA) was required to designate by early 1971 the most serious air pollution areas as air quality conliol reglons.261/ Under the Act, the States are required to treat as regions all areas of the State outside of the area designated by the EPA. 262/

\section{(b) Air Quality Criteria and Control Techniques.}

In addition to the designation of regions, the Administrator was required by early 1971 to publish a list of pollutants adversely affecting public health or welfare.263/ This list was to be kept up to date.264/ Thereafter the Administrator was required to issue criteria on air pollution which indicate the variables affecting same.265/ Also after consultation with appropriate Federal commissions and agencies, the Administrator was required to issue to the States and pollution control agencies information on air pollution control techniques.266/

\section{(c) Primary and Secondary Ambient Air Standards.}

While establishing the "Federal" regions, the Administrator was required to propose, by January 30, 1971, national standards for the first two of the three goals outlined above for six pollutants ( $\mathrm{SO2}$, particulates, CO photochemical oxidants, $\mathrm{HC}$, and N02).267/ These proposed regulations were published on January 30, 1971,268/ and finalized on April 30, 1971.269/ 
(d) State Implementation Plans.

Within set times after the promulgation of the national primary and secondary ambient air standards, the States were required to submit implementation plans addressing means by which the primary and secondary standards could be achieved within their jurisdiction.270/ The implementation plan had to outline a means by which the primary standards could be achieved within 3 years after approval of the plan by the Administrator, and the secondary standards within a reasonable time after approval.271/ The Administrator was given 4 months after submission of a plan to approve it pursuant to criteria set forth in the statute, 272/ and now in the regulations.273/ The Administrator was empowered to extend the time for satisfaction of the primary standards under certain circumstances.274/ In addition, if a State failed either to submit an implementation plan or to remedy deficiencies in the plan submitted and disapproved, the Administrator was required to promulgate proposed regulations for such State setting forth an implementation plan.275/

Set forth in the regulations now is a State-by-State description of the status of the implementation plans.276/ Despite the deadlines imposed by statute, many States still have not obtained complete approval of their implementation plans.277/ In addition, the Supreme Court has determined that strict adherence to an implementation plan is not required, so long as the national Ambient Air Quality Standards will be met.278/

\section{(e) No Significant Deterioration.}

As one of the purposes of the 1967 amendments to the Clean Air Act, Congress provided that the law should "protect and enhance the quality of the Nation's air resources so as to promote the public health and welfare and production capacity of its population."279/ In 1973, the Supreme Court concluded that State implementation plans must contain assurances that for those areas in which the air is of higher quality than the secondary standards there will be no significant deterioration in the quality of such air.280/ The decision was based on the above-quoted language. Subsequently, the EPA promulgated regulations embodying the non-deterinration policy.281/.

In August 1977, the regulatory plan was substantially codified into law by Congress.282/ The 1977 amendments require that national and international parks and wilderness areas exceeding a certain size be zoned in accordance with the statutory prescription. Otherwise, areas with air of higher quality than the secondary standards should be zoned into one of three categories in accordance with the individual State prescriptions.283/ The three categories, i.e., Classes I, II, and III, involve, respectively, decreasing limits on the quality of the air.284/ The areas mentioned above are federaliy zoned Class I. 285/ Other areas are zoned Class II or, under prescribed conditions, Class III by the Federal law until the individual States act to change the designation or zoning.286/ The amendments mandate that the implementation plans contain emission limitations and other measures necessary to prevent significant deterioration of the air quality.287/ Additionally, the statute imposes a permit system for any major polluting or emitting facility the construction of which is commenced after the date of enactment.288/ 
(f) Hazardous Pollutants and New Stationary Sources.

The 1970 amendments to the Clean Air Act authorize the Administrator to establish standards for both new hazardous pollutants289/ and new stationary sources of pollution which endanger public health or welfare.290/ The States then are required to submit plans implementing such standards.291/

\section{(3) Applicability to Indian Lands.}

(a) In General.

Until the 1977 amendments referred to above, the Clean Air Act made no reference to Indians. However, the Federal Government clearly has the authority to regulate Indian affairs.292/ The Supreme Court has concluded that, "general acts of Congress apply to Indians as well as others in the absence of a clear expression to the contrary."293/ Thus it seems clear that the Clean Air Act and the other national environmental statutes apply to Indians and non-Indians alike.

The serious question under the environmental statutes in general and the Clean Air Act in particular is the authority, if any, of the States over activities within the bounds of the Jicarilla Reservation.

\section{(b) Extent of State Authority.}

The question is whether the State of New Mexico has been given authority under the Clean Air Act to regulate activities on the Jicarilla

Reservation, authority which the State does not otherwise possess,294/ or whether regulation under the Act is to be performed by tribal authorities or, in lieu thereof, the EPA with the Tribe having, in effect, the status of a State thereunder.

The State of New Mexico has taken the view that pursuant to the Clean Air Act it has authority to regulate emissions on reservation lands.295 However, EPA in the regulations governing non-deterioration has stated that the Clean Air Act was not intended to grant additional authority to the States over Indian reservations.296/ The Administrator of the EPA in an in-house memorandum indicated his agreement with this view.297/ Culminating the debate over the above was the enactment of the $197 \overline{7}$ amendments dealing with nondegradation. For the first time in the history of the Act, these provisions not only refer to Indians expressly but also provide that lands within an Indian reservation are to be treated separately.298/ The tribal governing body is given the redesignation power, i.e., the power to change the "zoning"299/ either up or down from a Class II designation.300/ If a State is affected by a tribal redesignation, or if the tribe is affected by a State redesignation, the Administrator of the EPA is authorized to arbitrate and ultimately decide the controversy if the parties cannot agree. $301 /$ 
In any event, this statutory provision for Indians would seem rather arbitrary if it were not a part of an entire air pollution control program treating the reservations as States for all purposes under the Clean Air Act.

C. Federal Water Pollution Control Act. 302/

The discussion from Ernst \& Ernst, Planning Manual for Energy Resource Development on Indian Lands, Vo1. IV, The Environment (1977) (hereafter E\&E), p. IV-27 et seq., covers this topic in detail and is reprinted below.

When the Congress passed the FWPCA amendments of 1972, the approach to pollution control differed from that adopted for air quality. This Act places greater emphasis on controlling pollution at the point of discharge than on the ambient water quality of the nation's waterways. The Act established a goal of "zero discharge" of pullutants into navigable water by 1985. Interim goals for reducing effluent discharges into navigable rivers were set for 1977 and 1983. There are four major components of the national water pollution control program: (1) a National Pollution Discharge Elimination System (NPDES) that sets effluent limitations for existing and new point sources and required an NPDES permit before discharges will be allowed; (2) special restrictions on oil and similarly hazardous materials; (3) funding for state and areawide water quality planning and management; and (4) grants for the construction of wastewater treatment facilities.

Planning and Management Provisions. The FWPCA provides funding for four aspects of water quality planning and management: construction grants for public wastewater treatment systems; state and areawide planning, river basin planning, and measures to prevent degradation of high-quality waters.

First, under the NPDES, publicly owned wastewater discharges must comply with the EPA effluent limitations. Section 201 of the Act allows EPA to provide matching funds for the planning and construction of wastewater treatment facilities. To qualify for such funds, the project must be included as a priority on the state plans and have state approval. When states identify priority areas, they are required to emphasize the severity of the pollution, but must also consider the population affected, nondegradation of clean water, and consistency with the areawide and basin plans. Several tribes have made use of 201 funds, including the Navajo, Jicarilla, Yakima, and Fort Berthold.

Second, Section 208 provides federal support for comprehensive planning for water quality control on an areawide and/or state basis. Areawide planning agencies are designated either by the state governor(s) or by special procedures for self-designation. The criteria used to designate areawide agencies include the impacts of urban/industrial concentration, energy development, and/or the 
protection of unique scenic or recreational waters. The 208 plans develop a profile of anticipated development for the next 20 years; identify the point and non-point source impacts of that development; evaluate the feasibility and effectiveness of alternative systems to prevent pollution discharges and maintain (or improve) water quality; and identify the governmental units that will plan, finance, and construct the necessary facilities. Also, the 208 comprehensive plans are coordinated with areawide air quality maintenance plans, solid waste management, and land-use planning efforts.

Under the FWPCA, Indian tribes or an "authorized tribal organization" are assigned the legal status of a municipality. As a result, tribes are eligible for wastewater treatment construction grants, and they participate in water quality management programs. EPA has issued a policy memorandum specifically addressing tribal participation in 208 planning. This memo, "SAM-7," states that water quality management agencies must coordinate with all tribes within the designated area. The nature of tribal participation depends on the particular legal relationship between the tribes and the other jurisdictions. If the tribe is independent of state jurisdiction, then the tribe may opt either to be included in the areawide effort or to study its water quality problems individually. EPA, prefers tribal participation in areawide plans, but has procedures for either approach. If a tribe elects to participate in the areawide agency, EPA requires a tribal resolution or a similarly binding memorandum confirming the tribe's intent to cooperate in developing plans for the entire area. EPA also recommends setting forth specific procedures for representing the tribe's views in the deliberations. Tribes may receive direct funding if the state has no jurisdicliul under PL 280 , if subcontracting through the state or designated area is not possible, or if all practical steps to coordinate with the 208 agency have been taken. Other conditions for direct funding are that the state formally affirm that it authorizes part of its 208 allotment fund to the tribe, that is will review and comment on the tribe's plan, that it will imput the tribe's plan, that it will input the tribe's plans into state plans, and that the state will coordinate the two efforts. In February 1977, EPA awarded direct 208 grants to ten tribes.

Section 303(e) of the Act requires state and interstate water quality planning on the basis of river basins. These assessments of point and nonpoint-source impacts provide a context to areawide and state 208 plans, construction projects, and th water resources planning done by the Water Resources Council.

Finally, Section 302 of the Act enables EPA to restrict effluent discharges into pristine waters. Although a nondegradation program has not yet been adopted, it is expected to parallel the "no significant deterioration" measures under the Clean Air Act.

Performance Standards. The FWPCA created three programs to limit effluent discharges: (a) the NPDES, (b) prohibitions on the discharge 
of oil or hazardous substances in harmful quantities, and (c) a dredge and fill permit program.

The NPDES is a national permit program that allows, conditions, or prohibits the "discharge of pollutants from point souces into navigable waters, the contiguous zone, or the oceans" (40 CRF 125.1). Permits are contingent upon the following federal and state standards :

(a) Effluent Standards and Limitations. "Existing" point sources are required to use the "best practical control technology currently available" to control discharges (as defined by EPA) by 1977. By 1983, they must use the "best available technology economically available." EPA has proposed or issued effluent limitation guidelines for most major industrial groups, including power generation facilities and coal and uranium mining activities. "New" point sources must use the "best available demonstrated" control technology. In general, the "new" source standards are equivalent to the 1983 criteria for existing sources. "Nonpoint" sources of pollution (e.g., agricultural feedlots, mine runoff, etc.) are responsible for close to $40 \%$ or more of the violations of national water quality standards. Because the discharges are diffused, control of nonpoint sources depends on planning and management programs rather than specific. effluent limitations. EPA guidelines require "best management practices," which are being adopted by the appropriate state and local authorities through such vehicles as 208 planning.

(b) Pretreatment Standards. If industrial pollutants either (1) would disable operation of a municipal treatment facility, (2) cause the municipal system to exceed its effluent'limitations, or (3) are not treated by such a system, the Act requires that the industry treat the wastewater so that it meets the standards that apply to municipal discharges into receiving waters.

(c) Toxic Effluent Standards and Prohibitions. Whereas other effluent standards are based on economic and technological criteria, these standards are determined by several toxicity factors. General criteria include: degradability; persistance; toxicity after combination with other substances; concentration in the food chain; and others. However, the law forbids any discharges of warfare agents (chemical, biological, or radiological) or large levels of radioactive wastes into navigable waters. 
The FWPCA specifically disallows the discharge of oil or other hazardous substances into navigable or adjacent lands. EPA has issued regulations for the prevention of oil spills. They apply to onshore and offshore oil facilities that, due to location and size, could reasonably be expected to discharge oil in harmful quantities. Onshore owners and operators must prepare and submit a Spill Prevention Control and Countermeasure (SPCC) plan to the EPA. The Agency's guidelines for onshore facilities include controls for production facilities (wells, floodlines, separation equipment); drilling and workover facilities; drainage facilities (e.g., dikes); bulk storage tanks; transfer facilities, pumping, and in-process facilities; and loading and unloading and racks for tank cars and trucks.

Finally, Section 404 of the FWPCA authorizes the U.S. Army Corps of Engineers to issue permits for the discharge of dredge and fill materials into navigable waters. If a facility or associated activities would add or withdraw fill or dredge materials to such waters, then a permit would be required. This provision may affect energy conversion facilities, pipelines, electric transmission lines or other activities.

Enforcement Jurisdiction. EPA establishes effluent guidelines to be used for the NPDES permits, but the states that are delegated authority to implement the program are allowed to adopt more stringent standards. Of the ten states that have CERT tribes within their borders, five implement the NPDES: Colorado, Montana, North Dakota, Washington, and Wyoming. The oil and hazardous substances regulations are implemented by the EPA nationwide.

Title 40 of the CFR, Part 125.2, specifically states that federal NPDES regulations, not state laws, apply to both federal agencies and Indian activities on tribal lands. At this time, the states that have assumed NPDES have jurisdiction over non-Indians. In all other states, enforcement is the responsibility of the EPA. Since EPA is responsible for implementing the oil and hazardous substances regulations nationwide, the agency also enforces them on tribal lands.

\section{Federal Environmental Pesticide Control Act.303/}

The-discussion from E\&E, p. IV-26 et seq., is reprinted below.

This Act amended the Federal Insecticide, Fungicide, and Rodenticide Act (FIFRA) for three purposes: (1) to require the registration and classification of pesticides, herbicides, and similar chemicals; (2) to require certification of those who apply them, and extend their liability for misuse; and (3) to promulgate guidelines for the safe storage and disposal of these chemicals and related equipment. These EPA regulations control the application of herbicides and other retardants used for electric, gas, and other utility rights-of-way; oil or gas well-sites; mine reclamation; and similar activities. 
States have been delegated most of the enforcement responsibilities for these regulations. However, Part 171.10 of EPA's pesticide regulations specifically pertains to "Certifica- tion of Applicators on Indian Reservations." Under these provisions, a tribe that is not subject to state jurisdiction and that has an appropirate governing body may elect either to use the state certification program or to develop its own plan for certifying commercial and private applicators. If a tribe chooses to adopt and enforce its own regulations, it should enter into a cooperative agreement with the state on enforcement matters. Furthermore, it rules should be based on either state or federal guidelines, and must be approved by the EPA through the Department of the Interior. Non-Indians using restricted pesticides on reservations that are not subject to state federal guidelines, and must be approved by the EPA through the Department of the Interior. Non-Indians using restricted pesticides on reservations that are not subject to state jurisdiction must be certified either under the Tribal certification plan or a state plan accepted by the tribe.

\section{E. Noise Control Act. $304 /$}

The discussion from E\&E, P. IV-34, is reprinted below.

This Act adopts a national policy to protect people from noise emmissions that jeopardize health and welfare. In keeping with this policy, the Act provides (1) a policy that the primary responsibility for noise control is vested in state and local governments; (2) EPA technical assistance and research on noise control; and (3) EPA noise emission standards for railroads, motor vehicles, construction equipment, other transportation equipment, and certain manufactured products.

Under this Act, state, local, and other governmental units (e.g., Indian tribes) are encouraged to develop and adopt noise standards without interference from the federal government. The federal government's regulatory role is limited to the transportation and manufactured products 1 isted above. As such, it does not control "activities" on tribal lands.

F. Occupational Safety and Health Act.305/

The discussion from E\&E, P. IV-35, is reprinted below.

This Act created the Occupational Safety and Health Administration (OSHA) within the Department of Labor to develop safety standards for the work place. OSHA regulates virtually all employers engaged in interstate commerce with a program of standards, on-site inspections, fines, and citations. OSHA regulations include radiation standards for nongovernment operations that are based on the NRC's standards for occupational exposure. 
OSHA enforces these safety regulations on tribal lands in states that do not have an implementation plan (e.g., Montana, Oklahoma, North and South Dakota). There is dual state/federal enforcement in states that have standards but not an "operations" plan (e.g., New Mexico). In states that do have such plans, the emerging position is that OSHA will enforce the regulations for Indian activities on Indian lands and states will do so for non-Indian activities.

\section{G. Safe Drinking Water Act. 306/}

The discussion from E\&E, p. IV-35 et seq., is reprinted below.

The Safe Drinking Water Act (SDWA) has four major provisions: (1) primary and secondary standards for drinking water supplied by any public community system; (2) controls of underground injections that may contaminate drinking water supplies; (3) special restrictions of projects that might contaminate aquifer recharge zones that serve as primary or sole source of drinking water for a community; and (4) funds for research, demonstration, and technical assistance for water supply systems.

Planning and Management Provisions. The SDWA includes provisions to facilitate implementation of the water supply and underground water protection programs. First, the Congress has appropriated funds for the purpose of providing municipalities with technical assistance to establish water system management programs. The Act includes tribes in the definition of "municipality"; therefore, tribes are eligible for the research and technical assistance programs. However, these grants can be made only to the states; consequently, eligible tribes must receive either the funds or training through the states.

Second, the regulations for the underground injection control program require states to identify all aquifers that must be protected. The implementation plans must designate aquifers that (1) currently supply public water systems or (2) do not presently supply water but that have less than $10,000 \mathrm{mg} / 1$ of total dissolved solids. Likewise, aquifers may be excluded from the program if the sate indicates that the area is severely contaminated, is unsuitable due to location, or is strictly used for oil production.

Performance Standards. The SDWA mandates the following three sets of controls:

(1) Public Drinking Water Standards: Any community water system that serves at least 25 individuals or 15 regular customers on a regular basis $(60$ days per year) must comply with primary and secondary water standards. EPA has established interim primary drinking standards that limit organic, inorganic, and microbiological contaminant and turbidity levels. Standards for radio- 
activity are under development. Also, any new system must site the waterworks to minimize the risks of flood-ing, fire, and earthquakes and to circumvent tide levels and 100-year flood plains.

(2) Underground Injection Standards. Under this Act, states are required to submit programs to control underground injections by permits or rules that prevent injections that would "endanger" drinking water sources. EPA's proposed regulations (at the time this report was completed, the underground injection standards had not been issued as final regulations) sugges that injections endangert drinking water sources if (1) it becomes necessar for a public water system using the underground source to increase treatment; (2) it might be necessary for a publi water systemc that would us the water source in the future to use more extensive treatment than otherwise would be necessary; or (3) it might adversely affect publi health by making the wate unfit for human consumption. The rules by disposal wells, subsidence control wells, mining wells, geotherma wells, and oil and gas operations.

(3) Sole Source Standards. EPA has special review and program implementation procedures for developments that affect aquifer recharge zones that are the sole or principal source of a community's drinking water supply.

Enforcement Jurisdiction. This Act provides for state assumption of primary enforcement responsibilities for primary and secondary drinking water and underground injection standards where the state has the necessary legal authority and a program that complies with EPA guidelines.

The Act stipulates that federal agencies and water systems on Indian reservations must comply with the primary and secondary drinking water standards. For reservations that "own" water systems that are administered by the Indian Health Service (IHS), it will be necessary for EPA to work with the tribes and IHS to identify which authority will be responsible for compliance.

In a special opinion, EPA ruled that these drinking water standards would be administered by the EPA unless the state has authority pursuant to treaties (or enabling statutes) or if the tribe entered into an enforcement agreement with the state. The regulations for underground injection adopt a similar stance. If a state does not 
have jurisdiction or its jurisdiction is in question, EPA will enforce the regulations on tribal lands.

\section{H. Solid Waste Disposal Act and the Resource Conservation and Recovery Act. $307 /$}

The discussion from E\&E, P. IV-38 et seq., is reprinted below.

Until the passage of the Resource Conservation and Recovery Act of 1976 (RCRA), the federal approach to solid waste management was dictated by the Solid Waste Disposal Act. The SEDA provided federal financial and technical assistance to states and localities for the purpose of planning and developing environmentally sound methods of land disposal.

With the enactment of the RCRA, the Congress expended and accelerated federal and state regulation of solid and hazardous wastes. First, the definition of solid waste was amended to include "solid, liquid, semi-solid or contained gaseus material," and to exclude materials controlled by the Atomic Energy Act. Second, the RCRA provides for the implementation of state and regional solid waste plans. EPA must publish minimum guidelines for approving these plans; the law specifically requires the state plans to prohibit new open dumps and to close or upgrade existing ones. If the state plans are approved, the implementing agencies will be eligible for federal funds and assistance. EPA is to encourage a regional solid waste management and: to parallel the regions used for 208 planning to the extent practicable. Third, the RCRA provides for the regulations of hazardous wastes based on a permit system for treatment, storage, or disposal of hazardous wastes. EPA is required to issue regulations that establish (1) criteria for the identification of hazardous wastes, (2) a list of the hazardous wastes to be regulated, (3) regulations for the issuance of permits, and (4) guidelines for the development of state permit programs. Finally, EPA is required to implement these activities within specified time limits. Regulations for both hazardous wastes and state solid waste management plans are issued within 18 months after the passage of the Act (i.e., by April 1978).

Even though no regulations have been finalized for waste management, the agency has identified its initial approach to each area. In the case of hazardous wastes, EPA is directing its efforts toward developing standards for six aspects of this program:

- The identification of the hazardous wastes to be regulated. The criteria are likely to reflect toxicity, flammability, corrosiveness, and persistence and degradability in nature.

- The regulation of activities of generators of hazardous wastes. The standards are expected to 
emphasize the use of appropriate containers, labeling, and recordkeeping.

- The regulation os activities of owners and opertors of facilities to store, treat, or dispose of hazardous waste. Guidelines are expected to address the design, location, and construction of facilities as well as recordkeeping, reporting, and monitoring requirements.

- The issuance of permits by EPA or authorized state agencies. In addition to the performance criteria EPA is establishing the administrative procedures that will govern the issuance of permits.

- The delegation of permitting authority to states. EPA is in the process of publishing guidelines and criteria for authorizing state permit programs.

- The study and evaluation of current approaches to hazardous waste management.

The regulatory programs for solid waste are expected to include revisions of existing solid waste disposal guidelines and new standards for the disposal and utilization of sludge.

The solid waste plans are to be administered and enforced by state and regional authorities, subject to certain federal prerequisites, such as the mandatory prohibition of open burning. The hazardous waste management program will be implemented by EPA and states that have EPA-approved plans.

Neither the SWDA nor the RCRA specifically addresses enforcement for activities on tribal lands. A legal opinion by the EPA general counsel is pending on this questions.

Section III. Indian Civil Rights Act of 1968.308/

\section{A. History.}

There has been an extensive history of judicial decisions concluding that the U.S. Constitution did not protect people subject to tribal jurisdiction from tribal government. $309 /$ For example, the due process and equal protection clauses did not prevent a tribe from taxing only nontribal members for use of trust land.310/ The Fifth Amendment was held inapplicable to prevent a tribal taking of property.311/ The Sixth Amendment right to counsel has been held unavailable in tribal court. $312 /$

In 1968, Congress enacted the Indian Civil Rights Act in response to what many saw as an intolerable potential for abuses of authority by tribal governments. 313 / 
B. The Indian Civil Rights Act of 1968 .

\section{(1) In General.}

Although the Federal courts had been unwilling to impose constitutional constraints on tribal government, Congress finally did so in language almost verbatim to that in the Bill of Rights:

No Indian Tribe in exercising powers of self-government shall--

(1) make or enforce any law prohibiting the free exercise of religion, or abridging the freedom of speech, or of the press, or the right of the people peaceably to assemble and to petition for a redress of grievances;

(2) violate the right of the people to be secure in their persons, houses, papers, and effects against unreasonable search and seizures, nor issue warrants, but upon probable cause, supported by oath or affirmation, and particularly describing the place to be searched and the person or thing to be seized;

(3) subject any person for the same offense to be twice put in jeopardy;

(4) compel any person in any criminal case to be witness against himself;

(5) take any private property for a public use without just compensation;

(6) deny to any person in a criminal proceeding the right to a speedy and public trial, to be informed of the nature and cause of the accusation, to be confronted with the witnesses against him, to have compulsory process for obtaining witnesses in his favor, and at his own expense to have the assistance of counsel for his defense;

(7) require excessive bail, impose excessive fines, inflict cruel and unusual punishments, and in no event impose for conviction of any one offense any penalty or punishment greater than imprisonment for a term of six months or a fine of $\$ 500$, or both;

(8) deny to any person within its jurisdiction the equal protection of its laws or deprive any person of liberty or property without due process of law;

(9) pass any bill of attainder or ex post facto law;

or 
(10) deny to any person accused of an offense punishable by imprisonment the right, upon request, to a trial by jury of not less than six persons.314/

In addition the Act provides the writ of habeas corpus in Federal court to anyone wishing to test the validity of tribal imprisonment.315/ Omitted from the listed rights are the prohibition against establishment of religion, right to a jury in all criminal cases, right to appoint counsel, and the Fifteenth Amendment right to be free from racial discrimination.

\section{(2) Judicial Construction.}

\section{(a) General Principles.}

To a great extent it would appear that the courts are not construing these provisions and not applying the same standards as are being applied to the State and Federal Governments. Rather, the individual right is being balanced against the values of tribal culture and autonomy. Many courts appear to inquire whether a particular action is rooted in tribal culture, and if so, does the action affect everyone in an evenhanded way.316/ This test, however, has not been applied at the complete expense of the individual, even if the governmental action is culturally based. The Tenth Circuit has recently concluded that a Santa Clara Pueblo ordinance which proscribed membership in the Pueblo for children unless the father was a Pueblo member was invalid.317/ The United States Supreme Court in Santa Clara Pueblo v. Martinez, $3 \overline{17 a} /$ reversed the Tenth Circuit without a ion on decisthe equal protection issue. The Court concluded that the ICRA ot did nwaive the sovereign immunity of the tribes but rather only waived eign soverimmunity otherwise protecting tribal officials to the extent of habeas corpus proceedings to test the legality of detentions. $317 \mathrm{~b} /$ Thus ederal courts are open to parties challenging tribal actions only for bove limited purposes. If the Indian governmental action has no antial cultural base or is the product of capricious, tyrannical, or cious interest, value, or motivation, then a more traditional ruction of the rights provided for in the Act has been given. For le, the due process provisions of the Act were held violated by the al district court in South Dakota in a case in which one person acted dge and prosecutor in a tribal criminal case.318/ The equal ction and due process provisions were held violated by the same court tribal governmental procedure favoring one candidate for tribal office another,319/ by a tribe's not following its own laws providing for endum, $320 /$ and by an ordinance that was too vague in specifying prescribed conduct.321/ The allegation of a barring of use of an owned property right was held an allegation of a taking of property without due process by the Tenth Circuit,322/ and the exclusion from the reservation of a non-Indian because of his ridiculing the tribal government was held violative of the statutory right of free speech as well as an unlawful bill of attainder.323/ Now because of the Supreme Court's closing the doors to the Federal courts except for questionable detentions in the Martinez case,323a/ the only forum for vindication of the rights under the ICRA is tribal court. 
Although it would appear that non-Indians are also entitled to the protections provided under the Act,324/ it is likely that difficulties will arise in the future because of increasing non-Indian involvement in economic enterprises on reservation lands. It appears clear that the values of tribal culture, autonomy, and integrity justify a balancing of rights provided for in the Indian Civil Rights Act.325/ It would seem, therefore, that exclusion of non-Indians from tribal membership and from participation in tribal government would not violate the Act's equal protection clause.326/ In addition, tribal ordinances or resolutions giving preference to tribal members in providing access to tribal resources, including access onto the reservation, should be valid on the ground that thereby tribal autonomy and independence is furthered. Some of the limitations imposed on tribal government by the Act are more absolute and/or more specific in their purpose than others. Nevertheless, the limits on tribal government will certainly not be construed more severely than the same limits imposed by the Constitution on Federal and State governments. Additionally, in many if not most cases, the limits will be construed as being less constraining on tribal government because of the need to balance. With regard to the right of equal protection and due process, particularly, the point where lines will be drawn by tribal courts remains uncertain and unsettling, although the starting point may be the construction given to the Constitutional counterparts to these rights.

\section{(c) Waiver of Sovereign Immunity.}

As a general principle Indian tribes constituting limited sovereigns $326 a /$ may not be sued due to the applicability of the sovereign immunity rule unless Congress has provided otherwise.327/ In the ICRA, Congress has recently been construed as waiving that rule only for purposes of habeas corpus proceedings against tribal officials to test the legality of tribal detentions of individuals.328/ For Federal case law on the subject prior to the Martinez case, see Dry Creek Lodge, Inc., v. United States, 515 F.2d (9th Cir. 1975); Brown v. United States, 486 F.2d 658 (8th Cir. 1973); Johnson v. Lower Elwha Tribal Community of Lower Elwha Indian Reservation, 484 F.2d 700 ( 9 th Cir. 1973). Thus, for claims arising under the ICRA which involve matters other than detentions, the tribal court appears to be the appropriate forum.

\section{(d) Exhaustion of Tribal Remedies.}

Because of the perceived Congressional desire to preserve Indian culture and strengthen tribal government while protecting individual rights, the lower Federal courts have concluded that a plaintiff under the Act must exhaust available tribal remedies before resorting to the Federal courts.329/ However, the exhaustion requirement would not be furthered by imposing it, then is not imposed.330/ Additionally, courts have held that the need to exhaust one's tribal remedies must be balanced against the need to immediately adjudicate the alleged abridgement of the plaintiff's rights.331/ However, in view of the recent United States Supreme Court decision in Santa Clara Pueblo v. Martinez,33la/ the doors to Federal court have been closed to all cases arising under ICRA except those involving 
habeas corpus proceedings to determine the legality of detentions of individuals by the tribes.

Section IV. Federal Court Jurisdiction.

A. Criminal Jurisdiction. $332 /$

(1) In General.

Congress granted the Federal courts criminal jurisdiction over certain interracial acts constituting either Federal crimes or State crimes (where not federally proscribed). Additionally, Congress defined certain major crimes over which the Federal courts had jurisdiction whether interracial or solely between Indians. Each of the above applies only to Indian country, which is defined as follows:

Except as otherwise defined in sections 1154 and 1156 of this title [these sections exclude fee-patented land in non-Indian communities and rights-of-way through Indian reservations from the Indian country definition for purposes of 1 iquor-related crimes] the term "Indian country," - - means (a) all land within the limits of any Indian reservation under the jurisdiction of the United States Government, notwithstanding the issuance of any patent, and including rights-of-way running through the reservation, (b) al1-dependent Indian communities within the borders of the United States whether within the original or subsequently acquired territory thereof, and whether within or without the limits of a state, and (c) all Indian allotments, the Indian titles to which have not been extinguished, including rights-of-way running through the same.333/

(2) 18 U.S.C. Section 1152.

Section 1152 provides as follows:

Except as otherwise expressly provided by law, the general 1 aws of the United States as to the punishment of offenses committed in any place within the sole and exclusive jurisdiction of the United States, except the District of Columbia, shall extend to the Indian country.

This section shall not extend to offenses commited by one Indian against the person or property of another Indian, nor to any Indian committing any offense in the Indian country who has been punished by the local law of the tribe, or to any case where, by treaty stipulations, the exclusive jurisdiction over such offenses is or may be secured to the Indian tribes respectively. $334 /$ 
The statute clearly excepts crimes committed between Indians. Additionally, by judicial construction, crimes exclusively between non-Indians are excluded by the above.335/

As discussed below in Part II, the States were held to have jurisdiction over such matters. As a consequence of the exclusively Indian and exclusively non-Indian crimes exception, section 1152 probably only applies to crimes between Indians and non-Indians. The last exception in section 1152 relating to treaty prescription would appear to be not applicable to reservations located in New Mexico.336/

(3) The Assimilative Crimes Act--18 U.S.C. Section 13.

Section 1152, quoted and discussed immediately above, makes applicable to Indian country all of the Federal criminal laws applicable to areas within the sole and exclusive jurisdiction of the United States. Section 13, known as the Assimilative Crimes Act, incorporates and applies State law to areas within the sole and exclusive jurisdiction of the United States. As a consequence the U.S. Supreme Court has concluded that State criminal laws apply to Indian country by means of this double incorporation.337/ Nevertheless there are several limits on the applicability of state law. First, state law only applies to the extent that there are no federally defined crimes.338/ Second, the limits of section 1152 apply in this context so that crimes between exclusively non-Indians $339 /$ or exclusively Indians $340 /$ are not covered. It appears settled that the Act, therefore, only applies to crimes between Indians and non-Indians.341/

(4) The Major Crimes Act--18 U.S.C. Section 1153, as Amended.

In 1885 Congress, as a result of the famous case of Ex Parte Crow Dog, prescribed that 14 major offenses involving exclusively Indians or both Indians and non-Indians are Federal crimes.

B. Federal Court Civil Jurisdiction.

\section{(1) In General.}

Congress has provided the jurisdictional avenues for access to Federal court although such access is by no mean unlimited. In addition to the general diversity and Federal question bases, $343 /$ actions by Indians involving the right to an allotment, 344 / actions brought by recognized tribes involving controversies arising under Federal law, 345/ and actions involving the United States as a party $346 /$ all may be pursued in Federal court. As discussed below, civil rights actions under the Indian Civil Rights Act of $1968347 /$ are relegated to tribal court.347a/ The following is a brief discussion of these provisions.

\section{(2) Diversity Jurisdiction--28 U.S.C. Section 1332.}

In general the Federal district courts have original'jurisdiction where the matter in controversy is worth more than $\$ 10,000$ and the action is between citizens of different States. 
Federal diversity jurisdiction of 28 U.S.C. section 1332 is not applicable to suits by Indian tribes, because a tribe is not a citizen. of any State; this was decided in Standing Rock Sioux Indian Tribe v. Dorgan.347b/ As to individual Indians, the Eight and Ninth Circuit decisions are in conflict, the Eighth Circuit finding jurisdiction in Poitra v. Demarrias $347 \mathrm{c} /$ and the Ninth denying it in Littell v. Nakai $34 \overline{7 d /}$ and Hot Oil Service, Inc., v. Hall 347e/. Although the Supreme Court has denied certiorari in Poitra v. Demarrias, $347 \mathrm{f} /$ the two abovementioned Ninth Circuit cases held that diversity jurisdiction exists in those cases in which the State court would also have jurisdiction. In the two cases the State courts would not have had jurisdiction because diversity jurisdiction was held to not exist. $348 /$ The above question concerning this avenue of possible access to the Federal courts will eventually reach the Supreme Court for decision in view of the split between the circuits.

(3) Federal Question--28 U.S.C. Section 1331.

Where a matter at issue exceeds $\$ 10,000$ in value and arises under the Federal Constitution, laws, or treaties, the Federal district courts have original jurisdiction. This is subject to the limit in $28 \mathrm{U} . \mathrm{S} . \mathrm{C}$. section 1341 which withholds Federal jurisdiction in matters involving state taxes where a speedy and efficient remedy is available in State court. Because the United States as a trustee could have originally brought the action, U.S. Supreme Court concluded that section 1341 was not a bar.349/ As such would usually be the case, it is difficult to see how section 1341 would have an effect in such Federal question cases involving Indians.

\section{(4) Tribal Actions--28 U.S.C. Section 1362.}

The Federal district courts are given jurisdiction over civil actions arising under the Federal Constitution, laws, or treaties and brought by a recognized Indian tribe or band. Although there has been a history of disagreement about the "arising under" language in section 1362,350/ in 1976 the U.S. Supreme Court took the less constraining approach and said, "(I)t would appear that Congress contemplated that a tribe's access to Federal courts to litigate $a$ matter arising under the Constitution, laws, and treaties would be at least in some respects as broad as that of the United States suing as the tribe's trustee."351/

(5) United States as Party--28 U.S.C. Sections 1345-1346, 1491, $\underline{1505}$.

The Federal district courts have original jurisdiction over actions commenced by the United States.352/ On the other hand, it would appear that these provisions do not grant jurisdiction over suits brought by an individual or a tribe if the United States is not a party, even though the latter could have been in its capacity as trustee.353/

Additionally, the court of claims has general jurisdiction and the Federal district court has limited jurisdiction for claims against the United States, i.e., in the latter case for claims up to $\$ 10,000.354 /$ In general, 
however, such claims must be founded on Federal law or Federal contract. $355 /$

(6) Claims Involving Indian Allotments--28 U.S.C. Section 1353.

The Federal district courts have original jurisdiction over civil actions involving the right of any Indian person to an allotment under an Act of Congress or treaty. If the plaintiff Indian is asserting a right to an allotment in the first instance, then the Federal district court will have jurisdiction according to the Tenth Circuit356/ as well as the Ninth Circuit.357/ The Ninth Circuit also appears to permit suits under section 1353 to protect allotments as against the Federal government.358/ If, however, the plaintiff cannot establish a right to a certain decision or a government official concerning an allotment but rather only that the government official has discretion to decide one way or the other, then jurisdiction probably does not lie under section 1353 on the claim.359/

\section{(7) Civil Rights Actions--25 U.S.C. Sections 1302, 1303 and 28} U.S.C. Sections 1331,1343 .

The Indian Civil Rights Act was ruled by lower Federal courts to provide jurisdiction to the Federal district courts for matters arising thereunder.361/ In addition the Federal question of jurisdiction of section $133 i 362 /$ also appeared available. However, actions under the Indian Civil Rights Act were subject to the requirement that the plaintiff exhaust his tribal remedies as discussed above.363/ However, the United States Supreme Court in Santa Clara Pueblo v. Martinez 363a/ recently concluded that the Federal courts acquired no civil jurisdiction under the ICRA. Rather, jurisdiction only existed thereunder in habeas corpus proceedings to try the legality of tribal detentions.

\section{(8) Miscellaneous Provisions.}

For specific types of matters, jurisdiction in Federal court may be available for mandamus actions.364/ In order for mandamus to be a viable remedy, however, it must be established that the defendant owes a nondiscretionary, ministerial duty. $365 /$ The court of claims has jurisdiction over Indian claims arising under Federal law.366/ The Administrative Procedure Act $367 /$ may provide independent jurisdiction $368 /$ for review of administrative decisions. $369 /$

Section V. Federal Income Taxation.

\section{A. Federal Income Taxation in General.}

Because of Federal plenary power over Indian matters,370/ the principles that have evolved governing Federal taxation of Indians are unrelated to those governing State taxation of Indians. The latter area is discussed in Part II, below. In most contexts, a key principle in the construction of. law as applicable to Indian people is that; "Doubtful expressions are to be resolved in favor of the weak and defenseless people who are wards of the nation, dependent upon its protection and good faith."371/ In the context of Federal taxation, however, the above principle of construction has bowed 
to the general rule that exemptions to tax laws must be expressed or plainly derived from statute or, in this situation, treaty.372/ Thus, as a general.principle, it can be stated that individual Indians are subject to the Federal tax laws within the limits. The taxation of tribes, individual Indians, and non-Indians on Indian property will be discussed below.

\section{B. Tribal Income.}

Indian tribes are not taxable, entities; as a result, income in the hands of the tribe or the Federal Government in trust for the tribe and undistributed constructively or actually to tribal members is not subject to federal income taxation.373/ Serious question exists whether a corporation wholly owned by a tribe would receive such tax-free treatment because of its status as a separate entity; on the other hand, partnership income attributable to a tribe as a partner should be taxfree. However, official guidance is lacking on both issues. The Jicarilla IRA corporation, established to conduct tribal business on June 16, 1960, by Federal charter pursuant to that Act, should be exempt from Federal income tax just as the Tribe is exempt. This should be so, since it was intended by Congress to constitute the alter ego of the tribe for purposes of business matters. Nevertheless, enough doubt exists to justify application for a revenue ruling on the question.

\section{Non-Indian Income.}

Non-Indians earning income on the reservation are subject to the general tax laws. In Heiner v. Colonial Trust Co.,374/ the court stated:

Assuming that Indians are not subject to the income tax, as contended, the fact that they are wards of the government is not a persuasive reason for inferring a purpose to exempt from taxation the income of others derived from their dealing with Indians. Tax exemptions are never lightly to be inferred.375/

\section{Individual Indian Income.}

\section{(1) In General.}

With respect to income accruing to individual Indians, the state of the law is at present in some respects uncertain. The key case of Squire v. Capoeman, 376/ decided by the U.S. Supreme Court in 1956, answers certain of the questions concerning the tax law in this area and arguably answers other questions to which, as yet, the Internal Revenue Service (IRS) has not acceded.377/ In Capoeman, the issue was whether the proceeds of sale by the United States on behalf of an Indian couple of standing timber on lands within the Quinaielt Indian Reservation and allotted under the General Allotment Act of 1887 were subject to capital gains tax. The taxpayers, husband and wife, were full-blood, noncompetent Quinaielt Indians who were residents on the Reservation and who were allottees and holders of a trust patent to the land in question. The land was not suitable for agricultural purposes and had little value after the timber was cut. 
The Court, noting agreement with the principle stated above that exemptions to the tax laws should be clearly expressed, concluded that the General Allotment Act of 1887 contained such an exemption and that therefore such income was not subject to tax. The General Allotment Act directs the Federal Government to hold title to allotments for 25 years and thereafter to grant fee title "free and clear of all charge or incumbrance whatsoever." In addition, the Act as amended empowers the Secretary of the Interior to issue a fee patent at any time to a competent allottee and that "thereafter all restrictions as to sale, incumbrance, or taxation of said land shall be removed and said land shall not be liable to the satisfaction of any debt contracted prior to the issuing of such patent. - ."378/ Concluding that the fact that the Act with amendments predates the Federal income tax was irrelevant, $379 /$ the Court stated:

The wisdom of the congressional exemption from tax embodied in Section 6 of the General Allotment Act is manifested by the facts of the instant case. Respondent's timber constitutes the major value of his allotted land. The Government determined the conditions under which the cutting is made. Once logged off, the land is of little value. The land no longer serves the purpose of which it was by treaty set aside to his ancestors, and for which it was allotted to him. It can no longer be adequate to his needs and serve the purpose of bringing him finally to a state of competency and independence. Unless the proceeds of the timber sale are preserved for respondent, he cannot go forward when declared competent with the necessary chance of economic survival in competition with others. This chance is guaranteed by the tax exemption afforded by the General Allotment Act, and the solemn undertaking in the patent. It is unreasonable to infer that, in enacting the income tax law, Congress intended to limit or undermine the Government's undertaking. To tax respondent under these circumstances would, in the words of the court below, be "at least, a sorry breach of faith with these Indians." $380 /$

The prior U.S. Supreme Court case of Superintendent of the Five Civilized Tribes v. Commissioner of Internal Revenue, 381/ which held that income accruing from reinvested income from alloted lands was taxable,382/ was distinguished on the ground that:

The purpose of the allotment system was to protect the Indians' interest and "to prepare the Indians to take their place as independent, qualified members of the modern body politic" [citation omitted]. To this end it is necessary to preserve the trust and income derived directly therefrom, but it is not necessary to exempt reinivestment income from tax burdens. 383 /

Capoeman thus rendered exempt the direct income of land which is allotted under the General Allotment Act and which is in a trust or restricted status. The finding of a clear exemption from the language of the Act arguably constitutes a relaxation of the resolve expressed in the 
Superintendent case, distinguished therein, to exempt income only when expressly prescribed by Congress.

Because of the variety of prescriptions contained in statutes and treaties dealing with Indian matters, it is difficult to generalize. Nevertheless, it would appear that income received by individual Indians could be broken into four categories: (1) direct income from trust or restricted 1 ands allotted under the General Allotment Act, (2) direct income from trust or restricted lands allotted under other statutes or treaties, (3) direct income from tribal lands (with and without express exemption), and (4) income from other sources.

\section{(2) Individual Income from Allotments.}

The Capoeman case clearly speaks to the first category, rendering it exempt. Some have argued that it also speaks to the second and third categories, rendering them exempt in the absence of a prescription otherwise in the relevant statute or treaty.384/ The lower Federal courts and the Internal Revenue Service have given mixed and varying responses to these types of income. All would appear to agree that category (1), i.e., direct income from trust lands allotted under the General Allotment Act, is exempt to the allottee and certain transferees.385/ Direct income from such land is defined by the IRS as "rentals,386/ royalties, proceeds from the sale of the natural resources of the land, income from the sale of crops grown upon the land and from the use of the land grazing purposes, and income from the sale or exchange of cattle or other livestock raised on the land."387/ The ruling also confirms that proceeds of sale of such land while in a trust or restricted status is exempt.388/ A later ruling expands on the items of income considered direct by including as exempt income payments made to noncompetent, enrolled Indians in connection with trust or restricted land allotted under the General Allotment Act and held by such Indians under programs-administered by the Agricultural Stabilization and Conservation Service of the U.S. Department of Agriculture.389/ Category (2) lands, i.e., those allotted under other specific statutes or treaties, will be discussed below; the above discussion concerning direct income also pertains to such lands.

Category (1) and category (2) direct income must be accruing to an appropriate person to be exempt. The person must be a noncompetent, enrolled member of the tribe and of at least mixed blood of that tribe, according to the IRS.392/ In addition the IRS has indicated that the individual must be the allottee, or must have acquired the land by gift, device, or inheritance, or must have acquired such trust or restricted land by a voluntary exchange authorized by the Secretary of the Interior.393/ Additionally, restricted or trust lands are exempt if acquired by armslength purchases for such persons who are unable to handle their own affairs, who are unable' to make intrafamily transfers of allotments, or who are needy and require assistance in acquiring small amounts of land by deed form 5-183 where the purchase money consists of restricted funds.394/ Also restricted or trust lands acquired for such persons by the secretary of the Interior under the Indian Reorganization Act are exempt for such persons.395/ 
Category (2) or trust or restricted lands allotted under special acts or treaties to enrolled, noncompetent Indians earn exempt income, according to the IRS when:

(1) The land in question is held in trust by the United States Government; (2) such land is restricted and allotted and is held for an individual noncompetent Indian, and not for a tribe; (3) the income is "derived directly" from the land; (4) the statute, treaty or other authority involved evinces congressional intent that the allotment by used as a means of protecting the Indian until such time as he becomes competent; and (5) the authority in question contains language indicating clear congressional intent that the land, until conveyed in fee simple to the allottee, is not to be subject to taxation. If one or more of these five tests is not met, and if the income is not otherwise exempt by law, it is subject to Federal income taxation. $396 /$

The Ninth397/ and Tenth Circuits398/ appear to have read Capoeman broadly and have found exemptions implied in the language of several specific allotments acts. The Ninth Circuit stated:

The Commissioner argues that by reason of differences in the provisions of the General Allotment Act of 1887 and the Fort Belknap Allotment Act of March 3, 1921, 41 Stat. 1355, under which the allotted lands were granted, Squire v. Capoeman is not applicable. It is true that the Fort Belknap Allotment Act does not contain the provision that the allot ents are grantd "free of all charge of incumbrance." Federal policy toward particular Indian tribes is often manifested thorou $h$ a combination of general laws, special acts, treaties, and executive orders. All must be construed in pari ma eria in ascertaining congressional intent. . .

These acts manifest a Congressional intent that the benefits and restrictions of the General Allotment Act are to apply to all Indian allotments in the absence of special legislation indicating a different intent. This construction is of course in accord with long-standing Congressional policy of treating Indians equally except where differences in tribal circumstances justify special legislation. $39 /$

Thus, pursuant to this view and contrary to that of the Internal. Revenue Service indicated above, unless there is special provision otherwise, income accruing to qualified Indian owners from trust or restricted lands acquired under any allotment act or treaty would be exempt, assuming its direct derivation from such lands.400/ The court held a bonus paid for an oil and gas. lease on such lands was not taxable as not constituting oil or gas production:

Congress did accord to the Indians a different set of rules of taxation. The language of the statute purports to put Indians and other citizens of Oklahoma on equal footing only as regards 
mineral produced. The Indians still enjoy the special tax advantage as to other income from the allotted, restricted lands. That advantage must be preserved to carry out the Congressional purpose behind the allotment system which "was to protect the Indians' interest and 'to prepare the Indians to take their place as independent, qualifed members of the modern body politic, '" (Citing Capoeman.) Accord: Clark v. United States, 38 AFTR2d 76-5954 (D. Okla., 1976).

\section{(3) Individual Income from Tribal Lands.}

With respect to category (3) income, i.e., income earnings by an Indian directly or indirectly from tribal lands, there is no exemption unless Congress has provided otherwise. It has been argued that the purposes for exempting income earned by an Indian from alloted land are applicable so as to justify exempting income earned from tribal lands by an individual or distributed to an individual by the tribe after being earned by the latter. Additionally, it is argued that Capoeman justifies this conclusion in its willingness to infer a tax exemption in the General Allotment Act for the reasons given.401/ However, the Internal Revenue Service,402/ the tax court,403/ and the Eighth Circuit404/ have concluded that absent express exemptions such income is taxable to the individual. The U.S. Court of Claims in two companion cases405/ decided the question of the taxability of distributions to allottees under the Osage Allotment Act which reserved mineral rights in the tribe for a time and which required distribution of mineral proceeds called "headrights" to noncompetent allottees.406/ The court, reviewing plaintiff's argument based on Capoeman, noted that the Osage Allotment Act required "all royalties and bonuses arising [Osage mineral lands]. . .shall be disbursed to members of the Osage Tribe. . ."407/ Then it stated:

If the General Allotment Act implied nontaxability when it directed that trust property be turned over to the Indian after the trust period free of all charges, etc., certainly the implication is just the same in the Osage Allotment Act decreeing that all royalties and bonuses shall be turned over. If Federal income taxes are first withheld, all will not be turned over to the plaintiffs.

The Osage Allotment Act and the General Allotment Act have other devices in common. They speak of the relationship to the property in question as in trust. They prohibit the sale of mineral rights. They prohibit indebtedness of trust property or the subjecting of it to lien, levy, attachment or forced sale. They make competency the determinative factor in fixing the extent to which an individual Indian shall have control over his property. Parallel congressional purposes are apparent but the basic purpose is the one alluded to in Capoeman and that is to protect the property so that it will adequately serve the needs of the ward and finally bring him to a state of competency and independence. This chance is encouraged, if not guaranteed, by tax exemption. Since 1906 Congress has habitually defined those 
situations in which there should be no tax exemption for Indians. It has not at any time said that income from noncompetent Osage headrights should be subject to Federal income tax. If this is what it wanted it has had a clear opportunity on several occasions to say so since Blackbird in 1930. Its silence is conclusive. It follows that plaintiffs are entitled to recover.

The IRS has agreed with this result where the headright is paid to a noncompetent Osage. 409/ However, such payment made to a competent Indian is taxable in the view of the IRS.410/ The tax court appears in accord with the IRS on this question.411 Although the Eighth Circuit concluded, as noted above, that income from grazing received by a noncompetent Indian lessee of tribal trust land was taxable because not expressly exempt, the court of claims has concluded that income earned by a noncompetent Cherokee from use of tribal trust land was not taxable, $413 /$ finding a Congressional purpose to exempt and using the same rationale quoted above. The Court of Claims appears more willing to find a clear congressional expression of an exemption than other courts.414/

\section{(4) Individual Income from Other Sources.}

Category (4) income, i.e., that derived directly from sources other than tribal or allotted lands, appears rather clearly taxable. The U.S. Supreme Court in the case of Superintendent of the Five Civilized Tribes v. Commissioner415/ held income derived from reinvestment income which originally accrued from allotted lands was taxable as not clearly exempted. The Eighth and Ninth Circuits have held that salary money was taxable even to noncompetent, enrolled Indians.416/ Not only has the court of claims cuncluded, as discussed above, that income accruing from tribal trust land to a noncompetent tribal member is tax free, but also that income from such income, i.e., "reinvestment income," if the latter is the result of investment back into the trust land itself through improvements thereon. $\underline{417 /}$

\section{E. Basis for Allotted Lands.}

An additional question is raised concerning lands earning exempt income under categories ( 1 ) and (2), i.e., allotted lands. When the trust or restrictions are lifted and the fee simple patent has been issued, it is clear that the land's tax exempt status ends.418/ However, the question has existed whether the basis is the fair market value at the time the fee simple patent is received or the earlier value when the trust patent had been received. A Federal district court in Shepard v. United States $419 /$ held that the basis of the land is the fair market value at the time of the transfer in fee.420/ Capoeman was relied on for the result. Subsequently, the IRS, revising its view and indicating its agreement with Shepard, ruled that the fair market value at the time of the receipt of the fee simple patent is the amount of the basis unless such is less than the value at the time of the original allotment, in which event the latter amount becomes the basis. $\underline{421 /}$ 


\section{F. Tax Planning.}

Starting with the assumption that a primary goal is the minimization of Federal income tax impact on a mineral development project, and that a non-Indian group will carry out the actual mining operation, it would appear that the more production income that can be channeled to the Indian owners of the minerals, the greater will be the tax savings. As noted above, since the tribe per se is not a taxable entity under the present state of the law, and since direct income from allotted trust lands is immune from income tax liability under the circumstances described above, production income accruing to the tribe or to the Indian owner of the trust lands as described above should be income tax free.

It appears, then, that the means by which maximum advantage can be obtained from the tax law is to set up the mineral project with the Indians as mineral owners and the non-Indian miners as mining contractors, in the model of the U.S. Supreme Court case of Paragon Jewel Coal Co., Inc., v. Commissioner422/ In that case the taxpayer, who was the owner of several coal leases, contracted with certain miners who agreed to mine the coal for a fixed price per unit of production and deliver the mined coal to the taxpayer. The miners supplied their own equipment and formally and substantively acquired no title to the coal in place. The question was whether the taxpayer or the coal miners were entitled to depletion on the fixed price per ton paid the coal miners; the Court held that the taxpayer was, since the coal miners acquired no economic interest, i.e., depletable interest, in the coal in place.423/

One might, at first glance, think that if the tribes and qualified individual Indians are not taxable at all, then the depletion allowance would be of no benefit to them. Thus, would it not be better to channel the production income to a tax entity which can take advantage of the depletion allowance? However, the statutory or percentage depletion rate, which varies by statute with the mineral question, is only a deduction of percentage of gross production income, not over 22 percent.424/ On the other hand, the qualified Indian owners get in effect a 100 percent deduction because in the appropriate circumstances the income is not taxable at all.

In order to assure that the Indians and not the mining contractor have the economic interest, in effect the miner should have not only the formal but also the substantive appearance of being a contractor rather than a lease or mineral fee owner. A seeming "safe harbor" approach under the present state of the law $425 /$ requires: (1) that the mining contractor's rights be terminable on short notice, e.g., 60 or 90 days, with, of course, a right to remove equipment; (2) that the Indian mineral owner be given ultimate control over the operation; (3) that the mining contractor be compensated not in mineral production directly but rather in money, although a formula based on a fixed amount per unit of resource mined or produced appears quite viable; (4) that not only the mineral in the ground but also the mined mineral remain owned by the Indian mineral owner (presumably then the Indian owner will independently market the mined mineral). Clearly, any 
tax savings resulting from such an arrangement could possibly be divided up between the interested parties in the mining contract.

Nevertheless, the situation of many non-Indian miners is such that the above arrangement would not appear economically viable. If there is a substantial front end investment, there must be a means of recoupment. Secondly, many miners need a guaranteed supply of the mineral.

With regard to the first consideration immediately above, it might be required that any termination of the agreement without cause by the Indian mineral owner would require reimbursement for the miner's unrecouped initial investment. The second problem perhaps can be circumvented by the Indian mineral owner's giving the miner some sort of "right of first refusal" on the mined resource. A more risky means of guaranteeing supply to the miner is an option to purchase. Nevertheless, the cautious planner would obtain a ruling from the Internal Revenue Service before recommending a commitment to such a transaction.

Care should also be taken to avoid the possibility of corporation or association treatment which might result because of the marketing arrangement.426/ A corporation which constitutes a separate entity for tax purposes might jeopardize the tribal tax-exempt status to the extent that it exists.

One respected commentator recommends consideration of the partnership as a means of obtaining tax benefits and yet securing the nontax requirements.427/ The inevitable problems with special allocations under the Internal Revenue Code428/ are briefly discussed. If there is to be non-Indian capital in the venture, a partnership will not result in the creation of a separate entity for Federal income tax purposes and may nevertheless result in an immunity from any State taxes as, well until income is distributed to the non-Indian partner.429/

Section VI. Federal Trust Obligation.430/

A. Definition

In 1942 in deciding Seminole Nation v. United States, the Supreme Court cited a number of its prior decisions which had recognized the trust obligations of the government in dealing with Indian people and went on to say:

In carrying out its treaty obligations with the Indian tribes the Government is something more than a mere contracting party. Under a humane and self-imposed policy . . it has charged itself with moral obligations of the highest responsibility and trust. Its conduct, as disclosed in the acts of those who represent it in dealing with the Indians, should therefore be judged by the most exacting fiduciary standards.431/

There was an action for breach of fiduciary duty growing out of treaty obligations, and the opinion could be read narrowly to say that the 
government has only a moral obligation to observe "the most exacting fiduciary standards."

Without specifying that it was only a moral duty, later Supreme Court decisions cited Seminole Nation for imposing a duty "to exercise great care in administering its trust"432/ and "to deal fairly with Indians wherever located."433/ In United States v. Mason, the court of claims had held that the United States breached its fiduciary duty when it paid the Oklahoma estate tax on property which it held in trust for an Osage Indian without resisting payment of the tax. The Supreme Court reversed, emphasizing the doctrine of stare decisis and holding that the United States was entitled to rely on a prior Supreme Court decision 434/ which had upheld the validity of Oklahoma's inheritance tax as applied to restricted Osage Indians, and therefore did not breach its fiduciary duty. The Court applied ordinary trust principles, stating that the United States is "duty bound to exercise great care in administering its trust" with respect to the Osage Indians 435 and is "under a duty to exercise such care and skill as a man of ordinary prudence would exercise in dealing with his own property,"436/ although it is not an insurer of trust property and will not be subject to a surcharge if the trust property is diminished in value unless it failed to exercise the required care and skil1.436a/ The Court did not have to say, however, that "a fiduciary may never be held liable for reliance on prior decisions of [the Supreme] Court";437/ it found that the United States had acted with the required care and prudence in following its prior decision and failing to contest the tax.

\section{B. Specific Obligations.}

\section{(1) Investments.}

On March 19, 1975, the court of claims stated in Cheyenne-Arapahoe Tribes of Oklahoma v. United States $438 /$ that the U.S. Government breaches its fiduciary duty to manage Indian trust funds properly "by not making the funds productive, . . by not maximizing the productivity of funds, and by using the funds to its own benefit and to the detriment of the tribes." $439 /$ The court cited the passage in Seminole Nation quoted above440/ and pointed out that the plaintiffs were not claiming that Congress had breached its trust duties under the Constitution or treaties, but rather that the Bureau of Indian Affairs had not properly used the means provided by Congress for meeting the government's trust obligation.

The distinction between congressional and executive responsibility is important, for courts tend to regard actions taken under the plenary power of Congress as unjustifiable political questions. But here an executive agency was being sued for alleged breach of fiduciary duty, and this court was willing to specify what that duty included. The court held that the government's fiduciary duty includes the "obligation to maximize the trust income by prudent investment, and the trustee has the burden of proof to justify less than a maximum return."441/ Additionally,

[a] corollary duty is the responsibility to keep informed so that when a previously proper investment becomes improper, perhaps 
because of the opportunity for better (and equally safe)

investment elsewhere, funds can be reinvested. While the trustee

has a reasonable time in which to make the initial investment or to reinvest, he becomes liable for a breach of trust if that reasonable time is exceeded. $\underline{442 /}$

The court also ruled that the BIA policy of consulting the Indians before investing and their failure to give the advice requested will not excuse a failure of productivity, for

- . The Government was duty bound to make the maximum productive investment unless and until specifically told not to do so by a tribe and until [the Government] also made an independent judgment that the tribe's request was in its own interest. $.443 /$

Further, the court held the government liable for the difference between the 4 percent interest paid on trust funds held in the Treasury, and thus in effect borrowed from the Indians, and the maximum yield available from eligible investments outside.444/

\section{(2) Trust Obligations Imposed by Indian Nonintercourse Act.}

Recent decisions have found a trust or fiduciary obligation to protect Indian land imposed on the United States by the Indian Nonintercourse Act, $445 \%$ which is based on the Trade and Intercourse Act of June 30, 1834.445a/ By a provision similar to one in the first Indian Trade and Intercourse Act,446/ which was repeated in successive revisions of the Act, that statute invalidates any "purchase, grant, lease, or other conveyance of lands, or any title or claim thereto, from any Indian nation or tribe of Indians" unless made by treaty or convention in accordance with the Constitution, and was thus specifically designed to protect the Indians from unfair treatment in disposing of their lands. In United States v. Oneida Nation of New York, $447 /$ the court of claims found a Federal fiduciary duty toward the Indians originating in the first Trade and Intercourse Act and remanded the case to the Indian Claims Commission to decide the factual issue of whether the U.S. Government knew or could be held to have known of 23 treaties between the Oneidas and the State of New York. Even though the United States did not participate in those treaties, the court held that if the government had actual or constructive knowledge of them and failed to protect Indian land rights transferred thereby, there woud be a breach of the fiduciary obligation imposed by the statute. In Ft. Sill Apache Tribe of the State of Oklahoma v. United States, however, the court of claims refused to extend the section 177 special relationship and consequent Federal obligation to protect Indian tribes in their land dealings in order to require Federal protection of the intangible factors of tribal well-being, cultural advancement, and maintenance of tribal form and structure.448/ In Joint Tribal Council of the Passamaquoddy Tribe

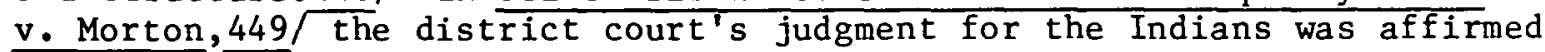
by a holding that the Indian Nonintercourse Act does establish a trust relationship between the United States and the Indian tribes, including the Passamaquoddy Tribe, whether federally recognized or not. The court 
cautioned, however, that its decision does not require the Department of the Interior to look to objects outside the Act in defining its fiduciary obligation, and found it appropriate that "the departments of the Federal Government charged with these responsibilities in matters should be allowed initially at least to give specific content to the declared fiduciary role." $450 /$ Thus, a court-approved definition of the government's fiduciary duties under the Indian Nonintercourse Act must await further litigation.

In the Administrative Appeal of Juanita Humphrey Michaleck, 451/ the Crow Agency Superintendent was held to owe a duty to protect the unleased trust land of a competent Crow Indian against livestock trespass. This case arose from the superintendent's refusal to seek punitive relief for livestock trespass on trust lands as provided in title 25 C.F.R., section 151.24 (1975) because he apparently misinterpreted the title 25 C.F.R., section 131.15 (e), provision giving any competent adult Crow full responsibility for obtaining compliance with terms of any lease made by him under that section. The Interior Board of Indian Appeals relied on the further provision of the section that "[t]his shall not preclude action by the Secretary to assure conservation and protection of these trust lands" in finding that the superintendent has an affirmative duty "to take such measures as . . . necessary to protect appellant against livestock trespass on her allotted land" $452 /$ as long as the land remains in trust status and unleased, even though it belongs to a Crow Indian classified as competent.

\section{(3) Mineral Development.}

The above principles should be applicable to impose on the Department of the Interior responsibility to expeditiously enforce all existing laws and regulations regarding mineral development in terms of operations and their effects on the environment and the local Indian community.453/ Difficulties also arise in determining the available remedies to enforce this responsbility. It would seem, however, that the equitable remedies to require enforcement should be as available as damages, particularly in view of the inadequacy of the latter in many cases.454/ 


\title{
FOOTNOTES
}

\author{
APPENDIX A, PART 1
}

1. 25 U.S.C. $\$ 177$.

2. United States v. Candelaria, 271 U.S. 432, 46 S. Ct. 561 (1926); Pueblo of Santa Rose V. Fall, 273 U.S. 315, 47 S. Ct. 361 (1927).

3. United States V. Candelaria, 271 U.S. 432 (1926), which indicates that even tribal lands acquired by fee simple patent from the United States are subject to the Act. See also 9 0p. Atty. Gen. 24 (1857); 18 op. Atty. Gen. 235 (1885), for the conclusion that the Act should be construed broadly.

4. See Sol. Op. 9-21-76, 3 Ind. L. Reptr. i-11.

5. Oneida Indian Nation v. County of Oneida, N.Y., 414 U.S. 661, 94 S. Ct. 772 (1973). 6. 18 Op. Atty. Gen. 235 (1885).

7. In United States V.Cook, 19 Wall. 591 (1873), it was held that the severance and sale of timber from tribal lands by the tribe was forbidden unless tor the purpose of improving the land. See also Pine River Logging Co. v. United States, 186 U.S. 279 (1902).

8. 25 U.S.C. $\$ 81$. The statute also applies to claims arising under Federal law or connected with or due from the United States.

9. 233 U.S. 558 (1914).

10. For a construction thereof see 180 Atty. Gen. 498, 60 I.D. 484.

11. 25 U.S.C. $\$ 477$.

12. Ibid.

13. See 25 U.S.C. \$396b; Federal Indian Law, (Dept. Int. 1958), p. 698, citing: Memos Sol. I.D. 1-12-37, 12-11-37. See however, Prop. 25 C.F.R. \$171.2a, 42 Fed. Reg. 37019 (7-19-77), wherein consent appears to be required even for such contracts. The same requirement is contained in the new comprehensive regulations proposed on 4-5-77 and discussed below in depth in the text to which note 142 et seq. is appended.

14. 25 U.S.C. $\$ 397$, relating to "bought and paid for" lands. See for a definition of "bought and paid for" lands, British Am. Pet. Co. v. Board, 299 U.S. 159, 164 (1936); Sol. Op. (11-7-77), 4 Ind. L: Reptr. H-7.

15. 25 U.S.C. $\$ 399$, relating to leases of metalliferous minerals in nine Western States including New Mexico.

16. U.S.C. $\$ 398$, relating to oil and gas leases on "bought and paid for" lands. See note 14 , supra.

17. 25 U.S.C. $\$ 400$ a, relating to mineral leases on tribal lands reserved for school or agency purposes. 
18. 25 U.S.C. $\$ 398$ a, relating to mineral leases on executive order lands.

19. 25 U.S.C. $\$ 396 \mathrm{a}-\mathrm{g}$.

20. 52 Stat. 347 .

21. 25 U.S.C. $\$ 396 \mathrm{~b}$.

22. 25 U.S.C. \$396a.

23. 25 U.S.C. $\$ 396$ b.

24. Ibid.

25. 25U.S.C. $\$ \$ 396 c, 396 \mathrm{~d}, 396 \mathrm{e}$, respectively.

26. In re Gila River Materials Corp., 3 Ind. L. Reptr. g-48 (D. Ariz. 1967); United States v. Labbitt, 334 F. Supp. 665 (D.C. Mont. 1971); United States v. 9,345.53 Acres of Land, 256 F. Supp. 603 (W.D.N.Y. 1966).

27. Labbitt v. United States, n. 26, supra; Sunny Cove Dev. Corp. v. F1ora Cruz, 3 I.B.L.A. 465 (1974); See also Schaghticoke Tribe v. Kent School Corp., 423 F. Supp. 780 (D. Conn. 1976).

28. Under the comprehensive proposed regulations published on 4-5-77 (discussed in the text to which notes 142 et seq. are appended) and under proposed regulations published on 7-19-77, 42 Fed. Reg. 37019, secretarial approval is required for such IRA chartered tribal contacts.

29. Analysis withheld because oil and gas producing lands on the Jicarilla Reservation are tribally owned.

30. 25 C.F.R. \$1.2.

31. Hallam v. Commerce Mining and Royalty Co., 49 F.2d 103 (10th Cir. 931), cert. denied, 284 U.S. 643 (1931); White Bird v. Eagle-Pitcher Co., 258 F. Supp. 308 (N.D. Okla. 1966).

32. Ibid.

33. 4 Ind. L. Reptr. 1-2.

34. See 4 Ind. L. Reptr. 102; 1 Ind. L. Reptr. 非, p. 59.

35. 25 U.S.C. \$396b; 25 C.F.R. \$171.2. See also Poafpybitty v. Skelly Oil Co., 390 U.S. 365 (1968).

36. 25 C.F.R. $\$ 171.3(\mathrm{a})$.

37. Section $5(b)(2)$.

38. 25 C.F.R. $\$ 171.30$.

39. 25 C.F.R. $\$ 171.3(a)$ :

At such times and in such manner as he may deem appropriate, after being authorized by the tribal council or other authorized representative of the tribe, the superintendent shall publish notices at least 30 days prior to the sale, unless a shorter period is authorized by Commissioner of Indian Affairs, that oil and gas lease on specific tracts, each of which shall be in a reasonably compact body, will be offered to the highest responsible bidder for a bonus consideration, in addition to stipulated rentals royalties. Each bid must be accompanied by a cashier's check, certified check or postal money order, payable to the payee designated in the invitation to bid, in an amount not less than 25 percent of the bonus bid. Within 30 days after notification of being the successful bidder, said bidder must remit the balance of the bonus, the first year's rental, and his share of the advertising costs, and shall file with the superintendent the lease in completed form. The superintendent may, for good and sufficient reasons, extend the time for the 
completion and submission of the lease form, but no extension shall be granted for remitting the balance of moneys due. If the successful bidder fails to pay the full consideration within said period, or fails to file the completed lease within said period or extension thereof, or if the lease is disapproved through no fault of the lessor or the Department of the Interior, 25 percent of the bonus bid will be forfeited for the use and benefit of the Indian lessor.

40. 25 C.F.R. $\$ 171.3(\mathrm{~b})$ :

All notices or advertisements of sales or oil and gas leases shall reserve to the Secretary of the Interior the right to reject all bids when in his judgment the interests of the Indians will be best served by so doing, and that if no satisfactory bid is received, or if the accepted bidder fails to complete the lease, or if the Secretary of the Interior shall determine that it is unwise in the interests of the Indians to accept the highest bid, the Secretary may readvertise such lease for sale, or if deemed advisable, with the consent of the tribal council or other governing tribal authorities, a lease may be made by private negotiations. The successful bidder or bidders will be required to pay his or their share of the advertising costs. Amounts received from unsuccessful bidders will be returned; but when no bid is accepted on a tract, the costs of advertising will be assessed against the applicant who requested that said tract be advertised.

41. Hallam v. Commerce Mining \& Royalty Co., 49 F.2d 103 (10th Cir. 1931). 42. Prop. 25 C.F.R. $\$ 171.2$ a; 42 Fed. Reg. 37109.

43. See the text to which notes 142 et seg. is appended.

44. See note 147 , infra.

45. 25 C.F.R. $\$ 171.10$.

46. 25 C.F.R. $\$ 171.6 a$.

47. 25 C.F.R. $\$ 171.6(\mathrm{~b})$.

48. 25 C.F.R. $\$ 171.6 \mathrm{c}$.

49. 25 C.F.R. \$171.5:

If the applicant for a lease is a corporation, it shall file evidence of authority of its officers to execute papers; and with its first application it shall also file a certified copy of its articles of incorporation, and, if foreign to the State in which the lands are located, evidence showing compliance with the corporation laws thereof. Statements of changes in officers and stockholders shall be furnished by a corporation lessee to the superintendent January 1 of each year, and at such other times as may be requested. Whenever deemed advisable in any case the supertindent may require a corporation applicant or lessee to file:

(a) Lists of officers, principal stockholders, and directors, with postoffice addresses and number of shares held by each.

(b) A sworn statement of the proper officer showing:

(1) The total number of shares of the capital stock actually issued and the amount of cash paid into the 
treasury on each share sold; or, if paid in property, the kind, quantity, and value of the same paid per share.

(2) of the stock sold, how much remains unpaid and subject to assessment.

(3) The amount of cash the company has in its treasury and el sewhere.

(4) The property, exclusive of cash, owned by the company and its value.

(5) The total indebtedness of the company and the nature of its obligations.

(6) Whether the applicant or any person controlling, controlled by or under common control with the applicant has filed any registration statement, application for registration, prospectus or offering sheet with the Securities and Exchange Commission persuant to the Securities Act of 1933 or the Securities Exchange Act of 1934 or said Commission's rules and regulations under said acts; if so, under what provisions of said acts or rules and regulations; and what disposition of any such statement, application, prospectus or offering sheet has been made.

(c) Affidavits of individual stockholders, setting forth in what corporations or with what persons, firms, or associations such individual stockholders are interested in mining leases on restricted lands within the State, and whether they hold such interests for themselves or in trust.

50. 25 C.F.R. $\$ 171.7$.

51. 25 C.F.R. $\$ 171.4$

52. Ibid.

53. 25 C.F.R. $\$ 171.3 a(a)$.

54. Ibid.

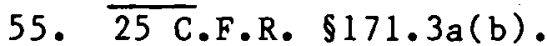

56. 25 C.F.R. $\$ 171.3 a(c)$.

57. 25 C.F.R. $\$ 171.6(\mathrm{~b})$.

58. 25 C.F.R. $\$ 171.30$.

59. 25 C.F.R. $\$ 171.8$.

60. 25 C.F.R. $\$ 171.9$ (a) Both the Northern Cheyenne and the Crow tribes have challenged the validity of mineral leases because of excessive acreage. Secretaries Morton and Kleppe have concluded that, because there was no demonstrated basis for waiving the acreage restrictions and because there had not been an explicit waiver thereof, the leases were invalid. I. Ind. L. Reptr. 非 7, p. 59; 4 Ind. L. Reptr. 1-2.

61. 25 C.F.R. $\$ 171.9(\mathrm{~b})(2)$.

62. 25 C.F.R. $\$ 171.10$.

63. Ibid.

64. See the discussion, infra, in the text to which note 180 is appended.

65. Continental Oil Co. v. Osage Oil and Ref. Co., 69 F.2d 19 (10th Cir. 1934); 58 I.D. 12 (1942); 64 I.D. 49 (1957); Continental Oil Co., IBIA 74-8-A (12-11-73), 1 Ind. L. Reptr., 非, p. 58; 3 Williams, 0 il and Gas Law $\$ 604.6$ (Matthew Bender, 1972).

66. Smith V. McCullough, 270 U.S. 456 (1926); Hallam v. Commerce Mining and Royalty Co., 49 F.2d 103 (10th Cir. 1931), cert. denied, 284 U.S. 643 (1931). 
67. See Clifton V. Koontz, 160 Tex. 82, 325 S.W.2d 684 (1959).

68. 25 U.S.C. $\$ 396$ a.

69. 25 C.F.R. $\$ 171.13$.

70. 25 C.F.R. $\$ 171.12(b)$.

71. White v. U.S. Fidelity \& Guaranty Co., 158 Okla. 296, 13 P.2d 1861 (1932); Plenninghausen v. Horinek, 158 Okla. 296, 240 Pac. 81 (1925).

72. 25 C.F.R. $\$ 171.12(b)$.

73. 25 C.F.R. $\$ 171.22,171.27$.

74. United States v. Forness, 125 F.2d 928 (2nd Cir. 1942), cert. denied, 315 U.S. 694.

75. See Navajo Tribe v. United States, 364 F.2d 320 (Ct. C1. 1966).

76. 25 C.F.R. $\$ 171.13$.

77. Ibid.

78. Ibid. See also, Navajo Tribe v. United States, 364 F.2d 320 (Ct. C1. 1966).

79. Ibid.

80. $\overline{\text { Ibid. }}$

81. See United States v. Stanolind Crude Oil Purchasing Co., 113 F.2d 194 (10th Cir. 1940), wherein a 3 percent deduction was made from gróss proceeds for dirt and sediment as agreed in a division order approved by the Secretary. The deduction, shown to be the custom of the industry, was upheld despite the lack of regulatory authorization.

82. 25 C.F.R. $\$ 171.13$.

83. Ibid.

84. 25 C.F.R. $\$ 171.1(\mathrm{~b}), 171.12,171.16$.

85. Ibid.

86. Ibid.

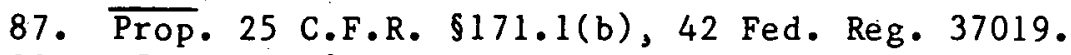

88. 25 C.F.R. $\$ 171.27$ a.

89. United States v. Wichita Industries, Inc., $390 \mathrm{~F}$. Supp. 1154

(W.D. Okla. 1974). See also United States v. Missouri-Kansas-Texas R.R. Co., 66 F.2d 919 (10th Cir. 1938); United States v. McMurray, 181 Fed. 723 (8th Cir. 1910).

90. See the text, supra, to which notes 30-34 are appended.

91. 25 U.S.C. $\$ 396 \mathrm{~d}$.

92. 25 C.F.R. $\$ 171.20$ (b).

93. See 30 C.F.R. $\$ 221.1$ et seq.

94. Ibid.

95. Prop. 25 C.F.R. \$171.2a, 42 Fed. Reg. 37019. These regulations are proposed pending final approval of the new comprehensive proposed regulations discussed in depth in the text infra, to which note 142 et seg. is appended.

96. 25 C.F.R. $\$ 171.1(\mathrm{~b})$.

97. Prop. 25 C.F.R. $\$ 171.1(\mathrm{~b}), 42$ Fed. Reg. 37019.

98. 25 C.F.R. $\$ 171.20$.

99. Ibid.

100. 25 C.F.R. \$171.19:

The lessee shall exercise diligence in drilling and operating wells for oil and gas on the leased lands while such products can be secured in paying quantities; carry on all operations in a good and workmanlike manner in accordance with approved 
methods and practice, having due regard for the prevention of waste of oil or gas developed on the land, or the entrance of water through wells drilled by the lessee to the productive sands or oil or gas-bearing strata to the destruction or injury of the oil or gas deposits, the preservation and conservation of the property for future productive operations, and to the health and safety of workmen and employees; plug securely all wells before abandoning the same and to shut off effectually all water from the oil- or gas-bearing strata; not drill any well within 200 feet of any house or barn on the premises without the lessor's written consent approved by the superintendent; carry out at his expense all reasonable orders and requirements of the supervisor relative to prevention of waste, and preservation of the property and the health and safety of workmen; bury all pipelines crossing tillable lands below plow depth unless other arrangements therefor are made with the superintendent; pay the lessor all damages to crops, buildings, and other improvements of the lessor occasioned by the lessee's operations: Provided, that the lessee shall not be held responsible for delays or casualties occasioned by causes beyond the lessee's control.

101. 25 C.F.R. $\$ 171.17$.

102. Ibid.

103. Ibid.

104. $\overline{\text { Ibid. }}$

105. Ibid.

106. 25 C.F.R. $\$ 171.18$.

107. Ibid.

108. $\overline{\text { Ibid. }}$

109. Ibid.

110. See the text, supra, to which notes 30-34 are appended.

111. 25 C.F.R. \$171.21.

112. Ibid.

113. 25 C.F.R. \$171.21(b).

114. 25 C.F.R. $\$ 171.26$.

115. Ibid.

116. Ibid.

117. A.E. McLane, $\mathrm{Oil}$ and Gas Leasing on Indian Lands, p. 112 (F.H. Gower \& Matthew P. Bender Co., 1955); F.M. Gibbons, "Examination of Indian Mineral Titles," 10 Rky. Mtn. Min. L. Inst. 73, 101-102 (1965).

118. 25 C.F.R. $\$ 171.26$.

119. Ibid.

120. Ibid.

121. Ibid.

122. $\overline{\text { Ibid. }}$

123. Ibid. See also Montana Eastern Limited v. United States, 97 F.2d 897 (9th Cir. 1938).

124. Ibid.

125. $\overline{\text { Ibid. }}$

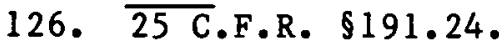

127. Ibid. 
128. Smith v. United States, 113 F.2d 191 (10th Cir. 1940). See, however, United States v. Pilot Oil Co., 54 F. Supp. 532 (D.C. Wyo. 1944), wherein equipment placed on property by one other than lessee was held removable even after the expiration of the specified time.

129. 25 C.F.R. $\$ 171.22$.

130. Ibid.; 25 C.F.R. $\$ 171.27(a)$.

131. Ibid.

132. Ibid.

133. Ibid. A recent court of claims decision held that forfeiture of the lease is only obtainable for a violation of the lease when the lease expressly calls for such forfeiture. Navajo Tribe v. United States, 364 F.2d 320 (Ct. Cl. 1966). However, the current lease form expressly provides for forfeiture on a violation of the lease, and the regulations of the Secretary are expressly made a part of the lease, so such holding would not bar enforcement of the regulatory provisions relating to forfeitures.

134. Prop. 25 C.F.R. $\$ 171.1$ (b), 42 Fed. Reg. 37019.

135. Sessions, Inc. v. Morton, 348 F. Supp. 694, 699 (C.D. Calif. 1972), aff'd, 491 F.2d 854 (9th Cir. 1974). See also the concurring opinion by Justice Brandeis in St. Joseph Stock Lands Co. v. United States, 298 U.S. 38, 84 (1936); dissenting opinion in Ortwein v. Schwab, 410 U.S. 656, 665 (1973); Hart, "The Power of Congress to Limit Jurisdiction of Federal Courts: An Exercise in Dialectic," 66 Harv. L. Rev. 1362 (1953); Schwartz, Administrative Law (Little, Brown \& Co., 1976), p. 439; Scott, "Administrative Law: Self-Determination and the Consent Power: The Role of the Government in Indian Decisons," 5 Am. Ind. L. Rev. 195, 201 et seg. (1977).

136. Kephart v. Richardson, 505 F.2d 1085 (3rd Cir. 1974); Breeden v. Weinberger, 493 F.2d 1002 (4th Cir. 1974); Kent v. Hardin, 425 F.2d 1345 (5th Cir. 1970); Alsbury v. U.S. Postal Service, 530 F.2d 852 (9th Cir. 1976); Polcover v. Secretary of the Treasury, 477 F.2d 1223 (D.C. Cir. 1973).

137. McCormick, Evidence (West, 1954), p. 677

138. Goldberg v. Kelly, 497 U.S. 254 (1970).

139. See Schwartz, Administrative Law (Little, Brown \& Co., 1976), pp. 192,224 et seq.

140. Goldberg V. Kelly, 497 U.S., at 271; wherein the Court says that the decision "must rest solely on the legal rules and evidence adduced at the hearing." The decisionmaker and the reviewer can as a practical matter only adequately make their determinations if a verbatim record is available to them.

141. 5 U.S.C. \$556(d); Schwartz, note 135, supra, at p. 349. See, however, Mezines, Stein, Gruff, 4 Administrative Law (Matthew Bender \& Co., 1977, pp. 24-29 et seq.

142. 42 Fed. Reg. 18083.

143. 42 Fed. Reg. 18084.

144. See the text, supra, to which notes $22-23$ are appended.

145. See the text, supra, to which notes 30-34 are appended.

146. Proposed 25 C.F.R. $\$ 182.11(a), 182.13$.

147. 25 U.S.C. $\$ 477$. See also, Federal Indian Law (Department of the Interior, 1958), pp. 698-699. 
148. See 25 U.S.C. $\$ 396 \mathrm{~b}$, wherein the 1938 Act makes optional the leasing powers under IRA but certainly does not make the latter exciusive for IRA (or "organized") tribes.

149. Prop. 25 C.F.R. $\$ 182.11$ (a), 42 Fed. Reg. 18094.

150. Prop. 25 C.F.R. $\$ 182.11$ (d), 42 Fed. Reg. 18095.

151. Prop. 25 C.F.R. $\$ 182.12,42$ Fed. Reg. 18095.

152. Ibid.

153. $\overline{\text { Ibid. }}$

154. Prop. 25 C.F.R. \$182.12, 42 Fed. Reg. 18095:

(c) Where the Secretary exercises his authority to enter into contracts on behalf of individual Indian mineral owners pursuant to $\$ 182.11(\mathrm{c})$ of this part, or where he has been requested by the Indian mineral owner under paragraph (a) of this section to assume the responsibility of awarding the contract, he shall offer contracts to the highest responsible qualified bidder subject to the following procedures, unless he determines in accordance with paragraph (d) of this section that the highest return can be obtained on the minerals by other methods of contracting (such as negotiation):

(1) Contracts shall be offered for a bonus consideration under sealed bids or public auction at least 30 days in advance of sale or such longer time as is necessary to achieve optimum competition.

(2) The advertisement shall specify any terms requested by the Indian mineral owner and may permit bidders to compete on such terms as rental and royalty rates as. well as upon bonus payment; and it shall provide that the Secretary reserves the right to reject any or all bids, and that acceptance of the contract bid or on behalf of the Indian mineral owner is required.

(3) Each bid must be accompanied by a cashier's check, certified check, or postal money order or any combination thereof, payable to the payee designated in the advertisement, in an amount not less than 25 percent of the bonus bid, which will be returned if that bid is unsuccessful.

(4) If no bid is received which meets the criteria of $\$ 182.13$, or if the accepted bidder fails to complete the contract, or if the Indian mineral owner refuses to accept the highest bid, the Secretary may readvertise the contract, or if deemed advisable, and in accordance with subsection (d) of this section, he may attempt to award a contract by private negotiations, provided that the Secretary shall not award a contract by private negotiations without the written concurrence of the Indian mineral owner unless he is exercising his authority under $\$ 182.11(c)$ of this part.

(5) A successful bidder must remit within 30 days after notification of the bid award the balance of the bonus, the first year's rental, a $\$ 25$ filing fee, and his share of the advedrtising costs, and all required 
bonds, with the Superintendent. The successful bidder shall also file the contract in completed form at that time. However, for good and explicit reasons the Secretary may grant an extension of time for filing of the contract. Failure on the part of the bidder to comply with the foregoing will result in forfeiture of 25 percent of any bonus bid for the use and benefit of the Indian mineral owner, in addition to pursuit of any and all other available remedies.

(d) If methods of contracting other than the competitive bid procedure are used, the Superintendent shall prepare written findings stating the reasons why it was more satisfactory than other methods, after consultation with the Mining Supervisor.

(e) Where the Indian mineral owner has requested the Secretary to offer a contract to the highest responsible bidder in accordance with paragraph (c) of this section, the Secretary shall advise the Indian mineral owner of the results of the bidding; and shall not award the contract to the successful bidder until the consent of the Indian mineral owner has been obtained.

155. Prop. 25 C.F.R. $\$ 182.12$ (b), 42 Fed. Reg. 18095.

156. Question exists under, subsection (d), quoted in note 154 whether that requirement applies in all cases or just in the situation referred to in subsection (c)(4), quoted in the same note. Although the organization of the section indicated the former, the' requirement imposed by the paragraph seems to just indicate only the latter.

157. This person is defined as the "Bureau Area Director or his authorized representative having immediate jurisdiction over oil and gas covered by a contract governed by the regulations of this part."

Prop. C.F.R. 182.2(a), 42 Fed. Reg. 18093.

158. Prop. 25 C.F.R. $\$ 182.11(a), 42$ Fed. Reg. 18094.

159. Prop. 25 C.F.R. $\$ 182.11(\mathrm{~b}), 42$ Fed. Reg. 18094.

160. Prop. 25 C.F.R. $\$ 182.11$ (a), 42 Fed. Reg. 18094.

161. See Hallman v. Commercial Mining and Royalty Co., 49 F.2d 103 (10th Cir. 1931); Barnett v. Kunkel, 259 Fed. 394 (8th Cir. 1919); Anchor 0il Co. v. Gray, 257 Fed. 277 (8th Cir. 1919), aff'd, 265 U.S. 519 (1921); Tykins v. McGrath, 184 U.S. 169 (1902); Texas-0kla. Pet. Co. v. Owens, 125 Okla. 167, 256 Pac. 483 (1926); Scioto Oil Co.v. D'Hern, 67 Okla. 106, 169 Pac. 483 (1917). These cases dealing with allotted lands conclude that the "relation back" doctrine applies with the result that the effective date of the conveyance is the executive date rather than the date of approval.

162. Prop. 25 C.F.R. \$182.15, 42 Fed. Reg. 18096:

(a) The Secretary may require a geological or geophysical permittee to furnish a surety bond in such amount as he deems advisable.

(b) Operators shall furnish a bond with each contract and assignees shall furnish a bond with each assignment in a sum of at least double the amount of the annual rental, but in no case less than $\$ 1,000$ per quarter-section of fractional quarter-section covered by a contract, and 
conditioned upon compliance with all the terms of the contract. Before beginning drilling operations, an additional bond in an amount to be determined by the Supervisor and the appropriate official must be furnished, but in no event less than $\$ 10,000$.

(c) In lieu of the lease or drilling bonds required under paragraph (b) of this section, the operator may file one bond for $\$ 50,000$ for all oil and gas contracts in any one state, or such lesser jurisdiction as determined by the Secretary, including contracts on that part of an Indian reservation extending into states contiguous thereto, to which the operator may become a party. The total acreage covered by such bond shall not exceed 10,240 acres.

(d) In lieu of the bonds required under paragraphs (a), (b), and $(c)$ of this section, an operator or permittee may file. a bond in the sum of $\$ 150,000$ for full nationwide coverage for all contracts and permits without geographic or acreage limitations.

(e) Bonds shall be corporate surety bonds.

(f) The right is specifically reserved to the Secretary to increase the amount of bonds in his discretion.

163. Prop. 25 C.F.R. \$182.14, 42 Fed. Reg. 18096:

(a) The signing in a representative capacity and delivery of bids, geological and geophysical permits, contracts or assignments, bonds, or other instruments required by these regulations constitutes certification.

164. Prop. 25 C.F.R. \$182.24, 42 Fed. Reg. 18098.

165. Prop. 25 C.F.R. $\$ 182.22,42$ Fed. Reg. 18097. See the text, supra, to which notes 53-56 are appended.

166. Prop. 25 C.F.R. $\$ 182.9,42$ Fed. Reg. 18094.

167. Ibid.

168. Prop. 25 C.F.R. $\$ 182.10,42$ Fed. Reg. 18094.

169. Prop. 25 C.F.R. $\$ 182.6($ a $), 42$ Fed. Reg. 18094.

170. Prop. 25 C.F.R. $\$ 182.12,42$ Fed. Reg. 18095.

171. Prop. 25 C.F.R. $\$ 182.11(\mathrm{a}), 42$ Fed. Reg. 18094.

172. Prop. 25 C.F.R. \$182.14, 42 Fed. Reg. 18096.

173. Prop. 25 C.F.R. $\$ 182.15$ (a), Fed. Reg. 18096.

174. Prop. 25 C.F.R. $\$ 182.24,42$ Fed. Reg. 18098.

175. Prop. 25 C.F.R. $\$ 182.11(\mathrm{a}), 42$ Fed. Reg. 18094.

176. Prop. 25 C.F.R. $\$ 182.2(\mathrm{~g}), 42$ Fed. Reg. 18094.

177. Prop. 25 C.F.R. $\$ 182.2$ (d), 42 Fed. Reg. 18093.

178. Prop. 25 C.F.R. $\$ 182.12(\mathrm{f}), 42 \mathrm{Fed}$. Reg. 18095.

179. Ibid.

180. Prop. 25 C.F.R. $\$ 182.12(\mathrm{~g}), 42$ Fed. Reg. 18095.

181. Prop. 25 C.F.R. $\$ 182.12(\mathrm{~h}-\mathrm{i}), 42$ Fed. Reg. 18095-6:

(h) In order to continue production in paying quantities, the operator must not suspend mining or production operations at any time for a period of 30 days or more without the prior express written approval of the Secretary unless production is impossible as a result of an Act of God or some other cause clearly beyond the operator's power to control. At the expiration of the principal term of the mining or 
production contract and at the end of each fiscal year thereafter until expiration of the contract, the operator shall present sufficiently detailed written evidence to the Indian mineral owner and to the Secretary to demonstrate under both standards above that minerals are being produced in paying quantities.

(i) Where development or production contracts are for a primary term of less that 10 years, it may be provided in the contract that if actual drilling operations have commenced prior to the end of the primary term and are being diligently prosecuted at the expiration of the primary term, and subject to the consent of the Indian mineral owner, the operator shall have the right to drill such well or wells to completion with reasonable diligence and, if oil or gas covered by the contract is found in paying quantities, the contract shall continue in force and effect as if such well or wells had been completed within the primary term. 182 . See the text, supra, to which note 21 is appended.

183. Prop. 25 C.F.R. $\$ 182.16 \overline{(a), 4} 42$ Fed. Reg. 18096.

184. Ibid.

185. Prop. 25 C.F.R. \$182.23(a), 42 Fed. Reg. 18097.

186. Prop. 25 C.F.R. $\$ 182.16$ (c), 42 Fed. Reg. 18096.

187. Prop. 25 C.F.R. $\$ 182.16$ (d), 42 Fed. Reg. 18096:

During the priod of supervison, "value" for the purpose of the lease may, in the discretion of the Secretary, be calculated on the basis of the highest price paid or offered at the time of production for a significant portion of the oil of the same gravity, gas, and/or natural gasoline, and/or all other hydrocarbon substances produced and sold from the field where the leased lands are situated, and the actual volume of the marketable product less the content of foreign substances as determined by the $0 i l$ and Gas Supervisor. The actual amount realized by the lessee from the sale of said products may, in the discretion of the Secretary, be deemed mere evidence of conclusive evidence of such value.

188. Prop. 25 C.F.R. $\$ 182.16$ (b), 42 Fed. Reg. 18096.

189. Ibid.

190. Prop. 25 C.F.R. $\$ 182.17,42$ Fed. Reg. 18096. See the discussion, supra, to which notes $84-87$ are appended.

191. Ibid.

192. Prop. 25 C.F.R. $\$ 182.16(\mathrm{e}), 42$ Fed. Reg. 18096. See the text, supra, which notes 82-82 are appended.

193. Prop. 25 C.F.R. $\$ 182.1$ (d), 42 Fed. Reg. 18093.

194. Ibid. This sentence in the proposed regulations causes some question because, although the regulations appear to require secretarial approval for all tribal contracts, the IRA does not appear to require approval for chartered tribal conveyance of not more than 10 years duration. See the text, supra, to which notes 12-13 are appended. Probably, however, this sentence in the proposed regulations is referring to all contracts for which the proposed regulations require approval.

195. Prop. 25 C.F.R. \$182.3, 42 Fed. Reg. 18094. 
195a. Ibid.

196. Prop. 25 C.F.R. \$182.4, 42 Fed. Reg. 18094.

197. Ibid.

198. Ibid.

199. Prop. 25 C.F.R. $\$ 182.11$ (b), 42 Fed. Reg. 18094.

200. Prop. 25 C.F.R. $\$ 182.4,42$ Fed. Reg. 18094.

201. Ibid.

202. Prop. 25 C.F.R. $\$ 182.18,42$ Fed. Reg. 18096-7.

203. Ibid.

204. Prop. 25 C.F.R. $\$ 182.20$ (a), 42 Fed. Reg. 18097.

205. Prop. 25 C.F.R. $\$ 182.20$ (b), 42 Fed. Reg. 18097.

206. Ibid.

207. Prop. 25 C.F.R. \$182.20(c), 42 Fed. Reg. 18097.

208. Ibid.

209. Ibid.

210. Prop. 25 C.F.R. $\$ 182.21,42$ Fed. Reg. 18097.

211. Ibid.

212. Prop. 25 C.F.R. $\$ 182.19(a-b), 42$ Fed. Reg. 18097. See the text, supra, to which notes $114-121$ are appended.

213. Ibid.

214. $\overline{\text { Ibid. }}$

215. Prop. 25 C.F.R. \$182.23(a), 42 Fed. Reg. 18097.

216. Prop. 25 C.F.R. $\$ 182.23$ (b-e), 42 Fed. Reg. 18097-8.

217. Ibid.

218. Ibid.

21. $\overline{\text { Ibid. }}$

220. Ibid.

221. Ibid.

222. Ibid.

223. Ibid.

224. Ibid.

225. Ibid.

226. Prop. 25 C.F.R. \$182.23(f), 42 Fed. Reg. 18098.

227. Prop. 25 C.F.R. $\$ 182.1(\mathrm{~d}), 42 \mathrm{Fed}$. Reg. 18093.

228. See the discussion, supra, to which notes $218-223$ are appended.

229. 42 U.S.C. $\$ 4331$ et seq. It is recommended that Ernst \& Ernst, Planning Manual for Energy Resource Development on Indian Lands, Vol. IV, The Environment (1978), p. II-I et seq., be consulted for a detailed discussion of the procedures involved in complying with NEPA and its shortcomings as applied to Indian lands.

230. Rodgers, Environmental Law (West, 1977), p. 697, citing Calvert Cliff's Coord. Comm. v. A.E.C., 449 F.2d 1109 (D.C. Cir. 1971), cert. denied, 404 U.S. 942 (1972).

231. 42 U.S.C. $\$ 4321$ : "The purposes of this chapter are: To declare a national policy which will encourage productive and enjoyable harmony between man and his environment; to promote efforts which will prevent or eliminate damage to the environment and biosphere and stimulate the health and welfare of man; to enrich the understanding of the ecological systems and natural resources important to the Nation; and to establish a Council on Environmental Quality."

232. 42 U.S.C. \$4331. 
233. Pye v. D.0.T. of Georgia, 513 F.2d 290 (5th Cir. 1975); Tanner v. Armco Steel Corp., 340 F. Supp. 532 (S.D. Tex. 1972); Environmental Defense Fund, Inc. v. Corp. of Engineers, 325 F. Supp. 749 (E.D. Ark. 1971).

234. 42 U.S.C. $\$ 4332$.

235. See Scientists' Institute for Public Information, Inc. v. A.E.C., 481 F.2d 1079 (D.C. Cir. 1973).

236. Ibid.

237. Ibid.

238. 42 U.S.C. $\$ 4333$.

239. 42 U.S.C. $\$ 4334.5$.

240. 42 'U.S.C. $\$ 4341$ et seq.

241. E.0. $11514(3-5-70)$.

242. 40 C.F.R. $\$ 1500$ et seq.

243. 469 F.2d 593 (10th Cir. 1972).

244. See also, Conservation Council of N.C. v. Costanzo, 398 F. Supp. 653 (E.D.N.C. 1975), aff'd, 528 F.2d 250.

245. Friends of the Earth, Inc. v. Butz, 406 F. Supp. 742 (D.C. Mont. 1975).

246. 43 U.S.C. $\$ 415$ et seq.

247. Natural Resources Defense Council, Inc., v. Morton, 388 F. Supp. 829 (D.C.D.C. 1974), aff'd, 528 F.2d 1386 (D.C. Cir. 1975); cert. denied, 427 U.S. 913.

248. Sierra Club v. Morton, 514 F.2d 856 (D.C. Cir. 1975); Cady v. Morton, 527 F.2d 786 (9th Cir. 1975)

249. Ernst \& Ernst, Planning Manual for Energy Resource Development on Indian Lands, Vol. IV, The Environment (1978), p. II-24.

250. 30 C.F.R. $\$ 221.21(6)$.

251. Talton V. Mayes, 163 U.S. 376 (1896).

252. Mescalero Apache Tribe v. Jones, 411 U.S. 145 (1973).

253. See 25.U.S.C. $\$ 181$ and the discussion thereof, supra, Part I, Section I A (1).

254. 42 U.S.C. $\$ 7401$ et seg.

255. P.L. 88-206, 77 Stat. 392 .

256. P.L. 89-272, 79 Stat. 992 .

257. P.L. 90-148, 81 Stat. 485 .

258. P.L. 91-604, 84 Stat. 1713 .

259. 42 U.S.C. $\$ \$ 7470-7491$.

260. 42 U.S.C. $\$ \$ 7407-7410$.

261. 42 U.S.C. $\$ 7407$.

262. Ibid.

263. 42 U.S.C. $\$ 7408$.

264. Ibid.

265. Ibid.

266. Ibid.

267. 42 U.S.C. $\$ 7409$.

268. 36 Fed. Reg. 1502 (1971).

269. 40 C.F.R. 50, 36 Fed. Reg. 22384 (1971).

270. 42 U.S.C. $\$ 7410$.

271. Ibid.

272. $\overline{\text { Ibid. }}$

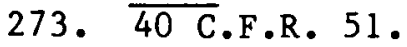


274. Ibid.

275. Ibid.

276. 40 C.F.R. 52 .

277. Ibid.

278. Train v. Natural Resources Defense Council, Inc., 421 U.S. 60 (1975), wherein a State procedure for granting limited variances from the implementation plan for particular sources was upheld even though such procedure was not provided for in the implementation plan.

279. 42 U.S.C. $\$ 7401$ (b)(1).

280. Fir v. Sierra Club, 412 U.S. 541.

281. 40 C.F.R. $\$ 52.01,52.21,39$ Fed. Reg. $42510(12-5-74)$.

282. P.L. 95-95, Part C, 160-169.

283. Ibid., \$162.

284. Ibid., \$163.

285. Ibid., $\$ 162$.

286. Ibid., \$164.

287. Ibid., \$161.

288. Ibid. $\$ 165$.

289. 42 U.S.C. $\$ 7412$.

290. 42 U.S.C. $\$ 7411$.

291. 42 U.S.C. $\$ 7411-7412$.

292. Worcester v. Georgia, 31 U.S. (6 Pet.) 515 (1832); Talton v. Mayes, 163 U.S. 376 (1896); Lone Wolf v. Hitchcock, 187 U.S. 553 (1903).

293. Federal Power Comm'n v. Tuscarora Indian Nation; 362 U.S. 99, 102 (1960). In Elk v. Wilkins, 112 U.S. 94 (1884), at p. 100 the Court stated in dictum which was rejected by Tuscarora, supra, at p. 116, that, "General Acts of Congress did not apply' to Indians, unless so expressed as to clearly manifest an intention to include them."

294. See the discussion, infra, Part II on State Auchority.

295. $39 \mathrm{Fed}$. Reg. 42513, amended $40 \mathrm{Fed}$. Reg. 25004. Additionally, case law from New Mexico appears to assume that State authority exists.

Norvell v. Ariz. Public Service Co., 510 P.2d 98 (1973).

296. 39 Fed. Reg. 42513, 42515; 40 Fed. Reg. 25004 (6-12-75); 40

C.F.R. $\$ 52.21$. Pursuant to the nondegradation regulations at 40 C.F $: R$. $\$ 52.2(\mathrm{c})(3)(\mathrm{v})$, the Northern Cheyenne Tribe has proposed redesignation of the Cheyenne River Sioux Reservation as a Class I area. 8 Env. L. Reptr. 17, 29.

297. 3 Legislative Review, 非, p. 5 (1975); see also, I. Kemper Will, "Environmental Protection of Indian Lands and Application of NEPA," Institute on Indian Land Development, p. 8-5 (Rky. Mtn. Min. L. Fdn., 1976) for a similar view by the then Asst. Reg. Counsel for EPA, Region VIII (Denver, Colo.).

298. P.L. 95-95, Part C, subpart 1, \$164 (c-e).

299. See the text, supra, to which note 282 et seq. is appended.

300. Note 298 , supra.

301. Ibid.

302. 33 U.S.C. $\$ 1251$ et seq.

303. 7 U.S.C. $\$ 135$ et seq.

304. 42 U.S.C. $\$ 4901$ et seq.

305. P.L. 91-596 \$12-29070, 84 Stat. 1590; 5 U.S.C. $\$ 51085,5314,5315$, 7902; 15 U.S.C. $\$ \$ 633,636 ; 18$ U.S.C. $\$ 1114 ; 29$ U.S.C. $\$ \$ 553$, 651-678; 42 U.S.C. \$3142-1; 49 U.S.C. \$1421. 
306. 42 U.S.C. $\$ 300 \mathrm{f}$ et seg.

307. 42 U.S.C. $\$ 6901$ et seq.

308. 25 U.S.C. $\$ 1301$ et seq.

309. Talton v. Mayes, 163 U.S. 376 (1896); Martinez v. Santa Clara Pueblo, 3 Ind. L. Reptr. F-20 (10th Cir. 1976); Tom v. Sutton, 3

Ind. L. Petr. e-21 (9th Cir. 1976); Barta v. Oglala Sioux Tribe, 259

F.2d 553 (8th Cir. 1958), cert. denied, 358 U.S. 932 (1959); Native American Church of North America v. Navajo Tribal Council, 272 F.2d 131 (10th Cir. 1959); United States v. Seneca Nation of New York Indians, 274 Fed. 946 (W.D.N.Y. 1921); Glover v. United States, 219 F. Supp. 19 (D. Mont. 1963). But see Colliflower v. Garland, 342 F.2d 369 (9th Cir. 1965).

310. Barta, note 309 , supra.

311. Seneca Nation, note 309 , supra.

312. Glover, note 309, supra.

313. Joseph D. Raismes, "The Indian Civil Rights Act of 1968 and the Pursuit of Responsible Tribal Self-Government," 20 S.D.L. Rev. 59 (1975); note, "The Indian Bill of Rights and the Constitutional Status of Tribal Government," 82 Harv. L. Rev. 1343 (1969).

314. 25 U.S.C. \$1302.

315. 25 U.S.C. $\$ 1303$.

316. See, e.g., Howlett v. The Salish and Kottenai Tribes, 529 F.2d 233 ( 9 th Cir. 1976); Wounded Head v. Tribal Council of Oglala Sioux Tribe, 507 F.2d 1079 (8th Cir. 1975); Crowe v. Eastern Band of Cherokee Indians, Inc., 506 F.2d 1231 (4th Cir. 1974); McCurdy v. Steele, 506 F.2d 653 (10th Cir. 1974).

317. Martinez v. Santa Clara Pueblo, 540 F.2d 1039 (10th Cir. 1976), cert. granted, 45 U.S.L.W. 3745 (May 17, 1977). The case is criticized in note, "Equal Protection Under the Equal Protection Act: Martinez v. Santa Clara Pueblo." 90 Harv. L. Rev. 617 (1976).

317a. 98 S.Ct. 1670 (1978).

$317 \mathrm{~b}$. Ibid.

318. Wounded Knee v. Andrea, 3 Ind. L. Reptr. g-131 (1976).

319. Keith v. Oglala Sioux Tribe, 3 Ind. L. Reptr. g-83 (1976).

320. Runs After v. Cheyenne River Sioux Tribe, 4 Ind. L. Reptr. F-137 (1977).

321. Big Eagle v. Andrea, 3 Ind. L. Reptr. g-113 (1976).

322. Dry Creek Lodge, Inc., v. United States, 515 F.2d 926 (1975).

323. Dodge v. Nakai, 298 F. Supp. 26 (D. Ariz. 1969).

323a. Note 317 a, supra.

324. Dry Creek Lodge Inc., v. United States, 515 F.2d 926 (10th Cir. 1975); Schantz v. White Lightning, 502 F.2d 67 (8th Cir. 1974); Jones v. Three Affiliated Tribes, 2 Ind. L. Reptr., 379 F. Supp. 1002 (D.S.D. 1974); Dodge v. Nakai, 298 F. Supp. 17 (D. Ariz. 1968).

325. See note 316 , supra.

326. See Daly v. United States, 483 F.2d 700 (8th Cir. 1973); Slattery v. Arapahoe Tribal Council, 453 F.2d 278 (10th Cir. 1971). See also Morton v. Mancari, 417 U.S. 535 (1974).

326a. United States v. Wheeler, 98 S.Ct. 1079 (1978); Santa Clara Pueblo v. Martinez, 98 S.Ct. 1670 (1978).

327. Turner v. United States, 248 U.S. 354 (1919); United States v. U.S. Fidelity Co., 309 U.S. 506 (1940); Thebo v. Choctow Tribe of 
Indians, 66 F.2d 372 (8th Cir. 1895); Cherokee Nation v. Oklahoma, 461 F.2d 674 (10th Cir. 1972), cert. denied, 409 U.S. 1039; Santa Clara Pueblo v. Martinez, 98 S.Ct. 1670 (1978).

328. Santa Clara Pueblo v. Martinez, note 327, supra.

329. Rosebud Sioux Tribe v. Driving Hawk, 534 F.2d 98 (8th Cir. 1976); Means v. Wilson, 522 F.2d 833 (8th Cir. 1975), cert. denied, 424 U.S. 958 .

330. St. Marks v. Chippewa-Cree Tribe of Rocky Boy Reservation, 4 Ind. L. Reptr. D-11 (9th Cir. 1976), wherein the tribal court had already considered the same issue for the same plantiff in a prior suit.

331. Necklace v. Tribal Court of the Three Affiliated Tribes of the Fort Berthold Reservation, 4 Ind. L. Reptr. C-4 (8th Cir. 1977), wherein plaintiff, who was involuntarily confined to a State hospital by order of tribal court, was held not obliged to exhaust her tribal remedies. See also O'Neal v. Cheyenne River Sioux Tribal Council, 482 F.2d 1140, 1146 (8th Cir. 1973); Brunette v. Dann, 417

F. Supp. 1382 (D. Idaho 1976); Clairmont v. Confederated Salish and Kootenai Tribes, 409 F. Supp. 1161 (D. Mont. 1976).

331a. 98 S.Ct. 1670 (1978).

332. See Robert N. Clinton, "Criminal Jurisdiction over Indian Lands: A Journey Through a Jurisdictional Maze," 18 Ariz. L. Rev. 503 (1976) (hereinafter Clinton), for a thoroughly researched, excellent discussion of the problems in this area.

333. 18 U.S.C. $\$ 1151$.

334. See Clinton, note 332 , supra, p. 523, for an outline of these crimes. In general these relate to Federal criminal laws prescribed for national parks and military installations.

335. United States v. McBratney, 104 U.S. 621 (1881); Draper v. United States, 164 U.S. 240 (1896); New York ex rel. Ray v. Martin, 326 U.S. 496 (1946). See also the discussion of this line of cases in Part II in the text to which note 3 et seq. is appended.

336. See Clinton, pp. 531-533, note 332, supra.

337. Williams v. United States, 327 U.S. 711 (1946).

338. Ibid.

339. Ibid., United States v. Dodge, 538 F.2d 770 (8th Cir. 1976).

340. Acunia v. United States, 404 F.2d (9th Cir. 1968).

341. See, however, United States v. Sosseur, 181 F.2d 873 (7th Cir. 1950), wherein the Assimilative Crimes Act was applied to a victimless crime involving a reservation Indian.

342. 109 U.S. 556 (1883).

343. 28 U.S.C. $\$ 1331,1332$.

344. 28 U.S.C. $\$ 1353$.

345. 28 U.S.C. $\$ 1362$.

346. 28 U.S.C. $\$ 1345,1346$.

347. 25 U.S.C. $\$ \$ 1302,1303$.

347a. Santa Clara Pueblo v. Martinez, 98 S.Ct. 1670 (1978).

347b. 535 F.2d 1135 (8th Cir. 1974).

347 c. 502 F.2d 23 (1974).

347d. 344 F.2d 486 (1965).

347e. 366 F.2d 295 (1966).

347 f. 421 U.S. 936 (1975). 
348. See the text, infra, Part III, to which note 130 et seq. are appended for a discussion of State court jurisdiction.

349. Moe v. Confederated Salish and Kottenai Tribes, 425 U.S. 46396 S.Ct. 1634 (1976).

350. The Tenth Circuit appears to have restricted it to the same Federal question standard arising under the general Federal question jurisdictional provision, i.e., section 1331. Mescalero Apache Tribe v. Martinez, 519 F.2d 479 (10th Cir. 1975). On the other hand, the Eighth and Ninth Circuits have construed the "arising under" language of section 1362 more broadly as permitting tribal action in any case in which the United States could have brought the action for the tribe as trustee. Standing Rock Sioux Indian Tribe v. Dorgan, 505 F.2d 1135 (8th Cir. 1974); Fort Mohave Tribe v. La Follette, 478 F.2d 1016 (9th Cir. 1973).

351. Confederated Salish and Kootenai Tribes v. Moe, 96 S. Ct. 1634, 1641 $(1976)$.

352. 28 U.S.C. $\$ 1345$.

353. United States v. Pawnee Business Council, 382 F. Supp. 54 (N.D. Okla. 1974).

354. 28 U.S.C. $\$ 1346,1491,1505$.

355. Ibid.

356. Prairie Band of Pattawatomie Tribe of Indians v. Puckee, 321 F.2d 767 (9th Cir. 1963); Dry Creek Lodge, Inc., v. United States, 515 F.2d 926 (10th Cir. 1975).

357. Scholder v. United States, 428 F.2d 1123 (9th Cir. 1970), cert. denied, 400 U.S. 942 (1970).

358. Ibid. See also Brooks v. Nez Perce County, 394 F. Supp. 869 (D. Idaho 1975).

359. Pallin v. United States, 496 F.2d 27 (9th Cir. 1974); Pence v. Morton, 391 F. Supp. 1021 (D. Alaska 1975).

360. See the discussion, supra, of the Indian Civil Rights Act of 1968 in the text to which note 314 et seq. is appended.

361. 28 U.S.C. $\$ 1343(4)$.

362. See the text, supra, to which note 349 et seq. is appended.

363. See the text, supra, to which note 329 et $\underline{\mathrm{seq}}$. is appended.

363a. 98 S.Ct. 1670 (1978).

364. 28-U.S.C. \$1361. See Byse and Fiocca, "Section 1361 of the Mandamus and Venue Act of 1962 and 'Nonstatutory' Judicial Review of Federal Administration Action," 81 Harv. L. Rev. 380 (1967).

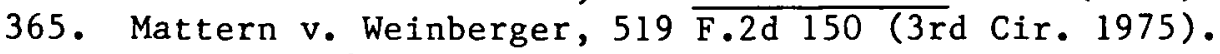

366. 28 U.S.C. $\$ 1505$.

367. 5 U.S.C. $\$ \$ 701-706$.

368. See, however, Zimmerman v. United States Government, 422 F.2d 326 (3rd Cir. 1970), wherein it was held that the Administrative Procedures Act did not grant jurisdiction to the Federal courts over matters not otherwise within their competence.

369. See Cramton, "Nonstatutory Review of Federal Administrative Action: The Need for Reform of Sovereign Immunity, Subject Matter Jurisdiction, and Parties Defendant," 68 Mich. L. Rev. 387, 444 (1970).

370. Choate v. Trapp, 224 U.S. 665 (1912). 
371. Worcester v. Georgia, 6 Pet. 515, 582 (1832); Carpenter v. Shaw, 280 U.S. 363, 367 (1930).

372. Squire v. Capoeman, 351 U.S. 1.(1956); Superintendent of the Five Civilized Tribes v. Comm'r of Internal Revenue, 295 U.S. 418 (1935).

373. The Kansas Indians, 72 U.S. (5 Wall.) 737, 755 (1866); Rev. Rul. 67-284, 1967-2 C.B. 55, citing Choteau v. Burnet, 283 U.S. 691 (1931).

374. 275 U.S. $232(1977)$.

375. Id. at 235. See also Helvering v. Mountain Producers Corporation, $\overline{303}$ U.S. $376(1938)$.

376. 351 U.S. 1 .

377. Discussion of this problem area can be found in Fiske and Wilson, "Federal Income Taxation of Indian Income from Restricted Indians Lands," 10 Land \& Water Law Rev. 1 (1975); Putzi, "Indians and Federal Income Taxation," 2 N.M. L. Rev. 200 (1972); Nelson, "Income from Indian Lands," 37 Taxes 301 (1959).

378. 3.51 U.S., at $6-7 ; 25$ U.S.C. $\$ 349$.

379. 351 U.S., at 7 .

380. Id. at 10 .

381. $\overline{295}$ U.S. 418 (1935).

382. Apply strictly the exemption principle referred to above.

383. Squire v. Capoeman, 351 U.S., at 9 (1956).

384: 351 U.S. 1 (1956).

385. Rev. Rul. 67-284, 1967-2 C.B. 55; Stevens v. Comm'r of Internal Revenue, 452 F.2d 741 (9th Cir. 1971).

386. This includes crop rentals.

387. Rev. Rul. 67-284, 1967-2 C.B. 55.

388. Ibid.

389. Rev. Ru1. 69-289, 1969-1 C.B. 34 .

390. Superintendent of Five Civilized Tribes v. Comm'r, 295 U.S. 418 (1935).

391. Rev. RuI. 67-284, 1967-2 C.B. 55.

392. Ibid.

393. Ibid.

394. Rev. Rul. 67-284, 1967-2 C.B. 55 .

395. Rev. Rul. 74-13, 1974-1 C.B. 14; Stevens v. Comm'r of Internal Revenue, 452 F.2d 741 (9th Cir. 1971), rev'g 52 T.C. 330 (1969) on this point.

396. Rev. Rul. 67-284, 1967-2 C.B. 55.

397. Stevens v. Comm'r of Internal Revenue, 452 F.2d 741 (9th Cir. 1971).

398. United States v. Hallam, 304 F.2d 620 (10th Cir. 1962).

399. 452 F.2d at 744-5.

400. An example of a liberal construction of special allotment act which expressly exempted the land from tax but which by amendment expressly rendered oil and gas production subject to State and Federal taxes is United States v. Daney, 370 F.2d 791 (10th Cir. 1966).

401. Fiske and Wilson, "Federal Taxation of Indian Income from Restricted Indian Land," 10 Land \& Water Law Rev. 63, 91 (1975); Putzi, "Indians and Federal Income Taxation," 2 N.M. L. Rev. 200, 213 et seq. (1972).

402. Rev. Rul. 58-320, 1958-1 C.B. 24; Rev. Ru1. 67-284, 1967-2 C.B. 55; Rev. Rul. 70-116, 1970-1 C.B. 11 . 
403. Bryan L. Stevens, 52 T.C. 330 (1969); Bentley L. Holt, 44 T.C. 686 (1965); aff'd, 364 F.2d 38 (8th Cir. 1966), cert. denied, 386 U.S. 931 .

404. Holt v. Comm'r of Internal Revenue, 364 F.2d 38 (8th Cir. 1966), cert. denied, 386 U.S. 931.

405. Big Eagle v. United States, 300 F.2d (1962); Red Eagle v. United States, 300 F.2d 772 (1962).

406. A headright is the interest that a member of the tribe has in the tribal trust estate with income therefrom. Shelton's Estate v. Oklahoma Tax Comm'n, 554 P.2d 495 (Okla. 1975).

407. $300 \mathrm{~F} .2 \mathrm{~d}$, at 771 .

408. Id. at 771-2.

409. Rev. Rul. 70-116, 1970-1 C.B. 11 .

410. Rev. Ru1. 77-78, 1977-14 IRB 8.

411. Jacqueline E. Shelton Est., 68 T.C. 15 (\#2) (1977), wherein headright income received by the estate of a deceased competent Osage was held taxable. The case is on appeal to the Tenth Circuit.

412. Holt v. CIR, 364 F.2d 38 (1966), cert. denied, 386 U.S. 931.

413. Critzer v. United States, 40 AFTR2d 77-5393 (1977).

414. The Fourth Circuit overturned the conviction for willful evasion of an Indian taxpayer who failed to report category three income. United States v. Critzer, 498 F.2d 1160 (1974). The Court stated, "As' a matter of law, defendant cannot be guilty of willfully evading and defeating income taxes on income, the taxability of which is so uncertain that even co-ordinate branches of the United States Government plausibly reach directly opposing conclusions" (p. 1162). 415. 295 U.S. 418 (1935), cited with approval and distinguished in Squire v. Capoeman, 351 U.S. 1 (1950).

416. TaFontaine v. CIR, $533 \mathrm{~F} .2 \mathrm{~d} 382$ (Oth Cix. 1976); Fry v. United States, 40 AFTR2d 77-5288 (9th Cir. 1977); CIR v. Walker, 326 F.2d 261 (9th Cir. 1964). See also Rev. Rul. 59-354, 1959-2 C.B. 24, wherein wages paid by the tribe to salaried tribal members for services were ruled taxable to the payee.

417. Critzer v. United States, 40 AFTR2d 77-5393 (Ct. C1. 1977).

418. Rev. Rul. 67-284, 1967-2 C.B. 55.

419. 162 F. Supp. 313 (E.D. Wis. 1958)

420. An earlier case, Dick v. Comm'r, 76 F.2d 265 (10th Cir. 1935), cert. denied, 296 U.S. 588, which involved an allotment in which at the outset was a fee simple patent with a simple restriction on alienation, held the value for purposes dated from the original allotment. Dick was distinguished in Shepard because of the different form of allotment in the latter case, i.e., by trust deed.

421. Rev. Ru1. 62-48, 1962-1 C.B. 131, modifying Rev. Rul. 58-341, 1958-2 C.B. 400. The date used to determine value in the latter event varies, depending on the time allotment. Check the latter ruling to determine the appropriate time for valuation.

422. 380 U.S. 624 (1964). See Maxfield, The Income Taxation of Mining Operations (Rky. Mtn. Min. L. Fdn., 2nd ed., 1975), Pp. 1-27, for a discussion of allowability of depletion and the concept of economic interest. 
423. Reference should be made to one of the several texts discussing at length this concept of "economic interest," including the one cited in note 422 , supra.

424. Assuming statutory or percentage depletion rather than cost depletion.

425. Paragon Jewel Coal Co., Inc., v. Comm'r, 380 U.S. 624 (1964); Parsons v. Smith, 359 U.S. 215 (1959); Winters. Coal Co., Inc., v. Comm'r, 496 F.2d 995 (5th Cir. 1974); Bakertown Coal Co., Inc., v. United States, 485 F. 2d 633 (Ct. C1. 1973); Rev. Ru1. 73-32, 1973-1 C.B. 301. See also: Rev. Rul. 74-460, 1974-2 C.B. 177; Rev. Rul. 74-506, 1974-2 C.B. 178 .

426. See Treas. Reg. Sec. 301.7701-2; I.T. 3930, 1948-2 C.B. 126; I.T. 3948, 1949-1 C.B. 161. See also Maxfield, Income Taxation of Mining Operations (Rky. Mtn. Min. L. Fdn., 2nd ed., 1975), p. 339 et seq.

427. Israel, "The Reemergence of Tribal Nationalism," Institute on Indian Lands Development--0il, Gas, Coal, and Other Minerals

(Rky. Mtn. L. Fdn., 1976), pp. 10-1, 10-36, n. 71.

428. I.R.C. $\$ 704$ (b).

429. See the discussion of state taxation in Part II, infra, in the text to which note 178 et seq. is appended.

430. For a thoroughly researched study of the Federal trust responsibility, see Chambers, "Judicial Enforcement of the Federal Trust Responsibility to Indians," 27 Stan. L. Rev. 1213 (1975) (hereinafter Chambers).

431. 316 U.S. 286, 296-7 (1942).

432. United States v. Mason, 412 U.S. 391, 398 (1973).

433. Morton v. Ruiz, 415 U.S. 199, 236 (1974).

434. West v. Oklahoma Tax Comm'n, 334 U.S. 717 (1948).

435. United States v. Mason, 412 U.S. 391; 398 (1973).

436. Id.

436a. $\overline{\text { Id. }}$.

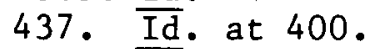

438. $\overline{512}$ F.2d 1390 (Ct. C1. 1975).

439. Id. at 1392 .

440. Note 431, supra.

441. 512 F.2d 1390, 1394 (1975).

442. Id.

443. $\overline{I d}$. at 1396 .

444. Id. See also Manchester Band of Pomo Indians v. United States, 363

F. Supp. 1238 (N.D. Calif. 1973); Navajo Tribe v. United States, 364 F.2d 320 (Ct. Cl. 1966).

445. 25 U.S.C. $\$ 177$ (1970).

445a. Ch. $161, \$ 12,4$ Stat. 730 .

446. Act of July 22, 1790, ch. 33, \$4, 1 Stat. 137, 138.

447. 4477 F.2d 939 (Ct. Cl. 1973).

448. 477 F.2d 1360, 1366 (Ct. Cl. 1973), cert. denied, 416 U.S. 993 (1974).

449. 528 F.2d 370 (1st Cir. 1975).

450. Id. at 379 .

451. IBIA 74-19-A, February 26, 1974, as reported in 1 Ind. L. Reptr. No. 4, 43 (April 1974). 
452. 1 Ind. L. Reptr., No. 4, 43 at 45 (1974).

453. See also Pyramid Lake Paiute Tribe v. Morton, 354 F. Supp. 252 (D.D.C. 1972).

454. See Chambers, pp. 1234-1238, note 430, supra. 
PART II

STATE JURISDICTION OVER

NON-P.L. 280 INTRARESERVATION MATTERS

Section I. General Principles.

A. Historical.

Historically, the States had no jurisdiction over Indians and lands within reservation boundaries. This absolute limitation was set forth in the often-cited case of Worcester v. Georgia 1/ which involved a Georgia statute requiring all white persons residing in Cherokee territory to obtain a license and swear allegiance to the State of Georgia. Samuel Worcester, a missionary, violated the statute and was arrested, convicted, and sentenced to 4 years hard labor. The Supreme Court, through Chief Justice Marshall, agreeing with Worcester's argument of the inapplicability of Georgia law, stated as follows:

The Cherokee nation, then, is a distinct community, occupying its own territory, with houndaries accurately described, in which the laws of Georgia can have no force, and which the citizens of Georgia have no right to enter, but with the assent of the Cherokees themselves, or in conformity with treaties, and with the acts of Congress. The whole intercourse between the United States and this nation, is, by our Constitution and laws, vested in the government of the United States.2/

Thus, essential to his view is the notion that the tribal sovereignty, which precluded the applicability of Georgia law functions to limit State authority not only in an in personam sense, but also in an in rem or geographic sense.

Fifty years later, however, the Supreme Court substantially tailored the legal significance of tribal sovereignty and the exclusivity of Federal and tribal power and expanded to the same extent State jurisdiction in United States v. McBratney.3/ In this case, a non-Indian was convicted in Federal court of the murder of another non-Indian in Indian territory under the Major Crimes Act, 4 / which applied to specified crimes occurring in areas within the exclusive jurisdiction of the United States. The Supreme Court, reasoning that the reservation was as much within State boundaries as any other area thereof, that only non-Indians were involved, and that the State 
of Colorado had not excepted the reservation from its jurisdiction, concluded that the State of Colorado had jurisdiction and therefore that the Federal court was without jurisdiction under the Major Crimes Act and that the conviction was improper. This conclusion, which was affirmed in two subsequent Supreme Court cases, $5 /$ might be argued contrary to expressions of the Court to provide only subject matter jurisdiction to the State court and not in personam jurisdiction over the non-Indian while within the reservation with the result that the territorial integrity of a reservation is thereby preserved, i.e., that the State's power is limited geographically.6/ However, in 1885 the Supreme Court held in Utah and Northern Railway v. Fisher $7 /$ that a territorial government could tax a non-Indian's personal property which was located within the bounds of a reservation, and enforce the tax by proper process.8/ Thus it would appear that the State is not limited in its jurisdiction in a geographical sense to areas outside the reservation. As a part of the cycle in the ebb and flow of the tide of Indian assimilation, P.L. 280 was enacted in 1953 to substantially increase State jurisdiction over reservation Indians and yet to avoid the wholesale abandonment of the Indians to State authority.8a/ The statute as originally enacted transferred limited civil and criminal jurisdiction to California, Minnesota, Nebraska, Oregon, and Wisconsin and tendered jurisdiction to the others. In 1958 the list was expanded to include Alaska.8b/ In 1968, as a part of the Indian Civil Rights Act, Congress amended P.L. 280 so that reservations were also provided a voice in the decision whether to come within P.L. $280.8 \mathrm{c} /$ In any event, although a number of States have acquired P.L. 280 jurisdiction, at least partially, the State of New Mexico had not acquired any authority thereunder. The sections below discuss the extent to which State jurisdiction over Indian lands is limited today inside the non-P.L. 280 reservation.

B. Non-P.L. 280--In General.

The Supreme Court has spoken a number of times in the last 20 years on the question of the jurisdiction of non-280 State law and the State courts over Indians and non-Indians on and off the reservation. $9 /$ As discussed below in detail, until 1973 one might have argued that in the situation involving Indians and non-Indians on the reservation, and possibly the former off the reservation, primarily one principle applied in matters involving civil jurisdiction, i.e., the "infringement" test.10/ This principle, as it developed, was a changing one, appearing to go almost full circle from one in 1959 of substantial exclusion of the State from reservation matters involving either solely Indians or both Indians and non-Indiansll/ to one of minimal exclusion in $1962.12 /$ Then the principle returned to almost complete exclusion in 1971.13/ Additionally, the primary emphasis in terms of justification for the exclusion appears to have evolved during that time from one of sovereignty in 1959 to one of preemption in 1971.14/ In any event, in part because of several 1973 decisions, it appears necessary today to break down the areas of concern into the several discussed below.

C. Indian Matters on the Non-280 Reservation.

In 1959, the Supreme Court decided Williams v. Lee,15/ which appeared to dispose of questions falling in this and the next section, i.e., matters 
involving both Indians and non-Indians on the reservation. The case involved a non-Indian trader, Hugo Lee, who sued in the Arizona State courts to collect an unpaid balance on a credit transaction occurring on the Navajo Reservation from an Indian couple, Paul and Lorena Williams. The Supreme Court concluded that the State courts had no jurisdiction over the matter. The Court noted Worcester v. Georgia, which applied a principle of absolute exclusion of State jurisdiction and stated:

Over the years this Court has modified these principles in cases when essential tribal relations were not involved and where the rights of Indians would not be jeopardized, but the basic policy of Worcester has remained. . . Essentially, absent governing Acts of Congress, the question has always been whether the state action infringed on the right of reservation Indians to make their own laws and be ruled by them.16/

The Court then concluded that "infringement" existed because the authority of the tribal courts over reservation matters would be undermined.17/

The problem with this minimum standard was its ambiguity; State courts had difficulty in applying it. Some courts used it to expand the perimeter of jurisdiction, 18/ while others considered it a substantial restriction.19/ The Supreme Court in dictum appeared to construe narrowly the Williams restriction on State jurisdiction in the 1962 opinion written by Justice Frankfurter in Village of Kake v. Egan.20/ He stated, "These decisions indicate that even on reservations state laws may be applied to Indians unless such application would interfere with reservation self-government or impair a right granted or reserved by federal law."21/

In 1971, the Supreme Court handed down Kennerly v. District Court of Montana,22/ discussed in detail in the next section. This case appears to have completely overshadowed the Williams case by concluding that P.L. 280, which is discussed below, provided the only means by which a State could assert jurisdiction over a reservation Indian and that State assertions of jurisdiction outside the procedure prescribed in P.L. 280 were thereby preempted. The Williams test of "infringement" was held inapplicable because P.L. 280 constituted a "governing Act of Congress" thereunder.

The Kennerly result was bolstered in 1973 by the Supreme Court decision in McClanahan v. Arizona Tax Comm'n.23/ The case involved the attempt of the State of Arizona to tax the income of Rosalind McClanahan, an enrolled member of the Navajo Tribe, who lived on the Navajo Reservation and earned the income in question there. The Arizona Court of Appeals, applying Williams, concluded that such income was taxable since there was no "infringement of the Navajo Tribe's right of self-government."24/ The Supreme Court reversed the decision of the Arizona courts, relying on three separate grounds.

First, the Court relied on the ground of general preemption as a limit on the applicability of Arizona's income tax law. The Court cited and quoted from the 1868 treaty with the Navajo nation which established the 
reservation and proscribed entries thereon by unauthorized non-Navajos. The Court noted that the treaty did not, however, provide that the Navajos were to be free from State law or exempt from State taxes. Then, citing the rule of Indian treaty construction that doubtful provisions are to be construed in favor of the Indian parties, and noting the purpose therefor of setting aside land for the exclusive use and occupancy of the Navajos, the Court concluded that the treaty precluded the extension of State law to Indians on the reservation. The Buck Act,25/ which authorized State taxation of those living in Federal areas except Indians, and the Arizona Enabling Act,26/ which required State disclaimer to all Indian lands, were also cited as demonstrating this general Federal preemption of State authority over the Navajos.

Second, the approach taken in the Kennerly case of distinguishing Williams and finding a specific preemption of State authority, except as prescribed in P.L. 280, was adopted in McClanahan. The Court stated:

- . But we cannot believe that Congress would have required consent of the Indians affected and the amendment of those state constitutions which prohibit the assumption of jurisdiction if the States were free to accomplish the same goal unilaterally by simple legislative enactment [citing Kennerly].27/

Third, Arizona argued that Williams and Kake justified the tax on the ground that the two cases "dealt principally with situations involving non-Indians"28/ and on the ground that they applied "only absent a governing act of Congress."29/ However, the Court held that even if the "infringement" test were applied it would preclude State authority to tax, since the right of self-government was affected. The Court also reasoned that the tribe essentially was no more than the sum of the individual Indians which made it up and the tax certainly affected the individual Indians. Thus, even the sovereignty, basis appears to have justified the result.30/ This conclusion was confirmed in the 1976 U.S. Supreme Court case of Fisher v. District Court of Sixteenth.Judicial District of Montana, $31 /$ wherein the Court concluded per curiam that the State courts did not have subject matter jurisdiction over an adoption dispute involving exclusively reservation Indians, not only because of the "infringement" test of Williams, but also because of the other reasons for the holding in McClanahan.

Thus, as to matters on the reservation involving exclusively Indians, it would appear that McClanahan expands the Kennerly holding and absolutely precludes State jurisdiction. Each of the three bases for the decision independently justifies the result and each of the three is probably applicable to any tribe located on a non-280 reservation. The holding of McClanahan has been reaffirmed in 1976 by the Supreme Court in Moe v. Confederated Salish and Kootenai Tribes,32/ wherein the State of Montana's personal property tax on automobiles, its cigarette vendor licensing statute, and its cigarette sales tax as applied to sales to reservation members were all held inapplicable to reservation Indians. However, the Court did hold that Montana could tax sales of cigarettes to non-Indians on the reservation and could require the Indian seller to 
collect the tax, since it was a tax imposed on the user, i.e., the non-Indian purchaser.33/

There are three possible areas in which State law could apply by Federal statute. These deal with allotted lands the trust period on which has expired;34/ the taxation of mineral production on executive order and "bought and paid for" lands; $35 /$ and State health, education, sanitation, and quarantine laws.36/ These various statutes are discussed below in the section on miscellaneous matters.

It would appear with regard to the type of matters involved in this section that tribal law37/ governs the legal relations of such parties and that State courts would have neither personal jurisdiction38/ nor subject matter fusridiction, i.e., legal competence, because of P. $\bar{L}$. 280 , as amended in 1968.39/ The subject matter jurisdiction would appear lacking because P.L. 280 provides a means of obtaining "jurisdiction over civil causes of action between Indians or to which Indians are parties" and not merely personal jurisdiction over an Indian defendant. These conclusions would appear required because of the significance given P.L. 280 in Kennerly and McClanahan as preempting other means of assuming jurisdiction which are not prescribed by Federal legislation.40/ The above conclusions appear to have been drawn in Montana, $41 /$ Arizona, $\underline{42 /}$ and New Mexico. $43 /$

To avoid personal liability, or for other business or personal reasons, Indians residing on the reservation may incorporate for purposes of conducting business on the reservation. If the incorporation is accomplished under tribal law exclusively, the above principles should clearly apply. However, if the incorporation is under State law, then, because the corporation is a separate entity and, arguably, because of the State incorporation, a non-Indian corporation, then the principles applicable to State jurisdiction over non-Indians discussed below in Section I $E$ would apply. In dictum, a 1974 Fifth Circuit decision concluded that a corporation is an entity separate from its shareholders and that, being incorporated under State law, it was, in effect, a non-Indian State citizen.44/ However, the New Mexico Court of Appeals 45/ disagreed for two reasons: First, New Mexico permits a piercing of the "corporate veil" in order to protect the public interest or the rights of the membership.46/ Second, despite its incorporation under State law it qualified as an "Indian corporation" under the Federal law establishing the Indian Business Development Fund47/ with its accompanying regulations $48 /$ and therefore had, under Federal law, an Indian identity despite its New Mexico State incorporation.49/ Though 49 percent of the stock was owned by non-Indian individuals, the corporation still qualified under the regulations which require that 51 percent be owned by Indians.50/ Yet, this decision should only be relied on in New Mexico; and, even there, hesitantly.

\section{Matters on the Non-280 Reservation Concerning Both} Indians and Non-Indians.

Two recent Supreme Court cases involve this circumstance. The Williams

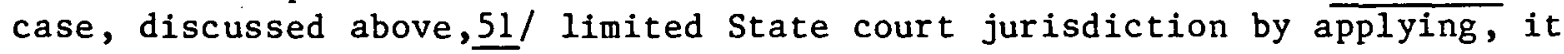


seems to this author, the doctrine of tribal sovereignty. The Court stated, "Essentially, absent governing Acts of Congress, the question has always been whether the state action infringed on the rights of reservation Indians to make their own laws and be ruled by them."52/ Williams involved a suit initiated in State court by a non-Indian against a reservation Indian, in which the Supreme Court held that the State court had no jurisdiction. The Court held that to hold otherwise would undermine the tribal court system and therefore tribal government.

The second Supreme Court case, referred to above, which involved the subject of this section was Kennerly v. District Court of Montana.53/ That case was similar to Williams in that it involved a suit initiated by a non-Indian in State court against a reservation Indian who purchased food on credit from a grocery store located within the town limits of Browning, a town incorporated under the laws of Montana but located within the exterior boundaries of the Blackfeet Reservation. In 1967 the tribal council had enacted a resolution giving the state and tribal courts concurrent jurisdiction over all suits with an Indian defendant where the cause of action arose on the reservation. The Montana Supreme Court held that the State court had jurisdiction since under Williams there was no "infringement" on tribal self-government in light of the 1967 resolution of the tribal council.

The U.S. Supreme Court reversed the Montana Supreme Court, holding that the Williams test of "infringement" was inapplicable because there was a "governing Act of Congress," i.e., P.L. 280 as amended in 1968.54/ Since P.L. 280, as amended, prescribed a procedure for a State's assuming jurisdiction, that procedure must be followed. State exercises of jurisdiction that fail to follow P.L. 280 procedures or other Federal procedures are preempted.55/ Thus, jurisdiction of State courts over reservation Indians concerning matters arising on the reservation appears to be lacking unless the procedure prescribed in P.L. 280 has been followed.

Even though the McClanahan case, discussed in the preceding section, distinguished the Williams holding as being applicable to reservation matters involving both an Indian and a non-Indian, the effect of the holding in Kennerly is to overshadow Williams and to preclude State authority essentially as exclusively as McClanahan did in reservation matters involving exclusively Indians.

Again, as concluded in the prior section, it would appear that Kennerly and McClanahan would require a conclusion that tribal law, rather than State law, governs the legal relations involved in this section. Additionally, a State court would appear to lack subject matter jurisdiction over such transactions $56 /$ and personal jurisdiction over an Indian civil defendant except that the latter would appear to exist where service is made of $f$ the reservation. These conclusions appear to be required because of the significance given P.L. 280 , as amended, as preempting any means of asserting State jurisdiction which are not federally specified. 
Thus, if a non-Indian wishes to vindicate a claim which has arisen on the reservation against a reservation Indian, tribal court is the proper forum, assuming no tribal constitutional limits. It would appear that even though the defendant is served off the reservation, the State court would lack subject matter jurisdiction because of the preempting effect of P.L. 280 as amended. Since, however, it appears well settled that an Indian may sue in State court, 57/ such subject matter jurisdiction may possibly be given the State court by consent of the Indian defendant.58/ Federal court may provide a forum in the cases involving a Federal question and possibly in diversity cases (see Part I on Federal Authority). Because many tribal codes exclude matters involving non-Indians, a serious question exists when the plaintiff is a non-Indian and there is no diversity of citizenship and the State has not taken P.L. 280 jurisdiction. In effect a plaintiff may have no forum for this action, 59/ although the Indian Civil Rights Act of $196860 \%$ may well invalidate such tribal code provisions on equal protection grounds.

E. Non-Indian Matters on a Non-280 Reservation.

As noted in the discussion in the introductory section in this Part, the U.S. Supreme Court in United States v. McBratney 62/ held that the State had criminal jurisdiction over a non-Indian who was convicted of the murder of another non-Indian on an Indian reservation. The existence of State jurisdiction over such matters has since been confirmed.63/ As noted above, in 1885. in Utah and Northern Railway v. Fisher, State jurisdiction was held to exist over non-Indians within the reservation to the extent at least that the State could tax their personal property located on the reservation and enforce the tax by proper process independent of reservation authorities.64/ The Supreme Court in McClanahan v. State Tax Comm'n of Arizona 65/ appears to have approved of conclusions drawn in these cases when it said, "Similarly, notions of Indian sovereignty have been adjusted to take account of the State's legitimate interests in regulating the affairs on non-Indians" (citing several of the cases cited above).66/ Then, in 1976, the Supreme Court in Moe v. Confederated Salish and Kootenai Tribes $67 /$ reconfirmed this line of cases by holding that, independent of P.L. 280 , a State may require that a reservation Indian collect a sales tax on cigarettes bought on the reservation by a nonIndian, if the tax is a user tax, the burden of which is imposed on the purchaser. In any event in the absence of Federal legislation proscribing such State regulation, there appear to be at least two alternative, settled limits on State authority over such matters.

First, there are certain matters over which the State would not appear to have authority because the Federal government has preempted the field by regulating so comprehensively that no room remains for State regulation. The 1965. U.S. Supreme Court case of Warren Trading Post v. Arizona Tax Comm'n 68/ involved such a situation. Arizona attempted to levy a 2 percent sales tax on the gross proceeds of the Warren Trading Post Co., a retail trading business located on the Navajo Reservation and operating under a Federal license. The Court noted that, pursuant to statute, the Commissioner of Indian Affairs has regulated quite minutely qualifications for traders, licensing procedures, penalties for violation, conditions for 
operation, recordkeeping obligations, etc. Because of such regulations and the desired protection for reservation Indians that results therefrom, the Supreme Court held that there was no room for State regulation or burden since the latter "could thereby disturb and disarrange the statutory plan Congress set up in order to protect Indians against prices deemed unfair or unreasonable by the Indian commissioner."69/

Second, as noted below in Part III on Tribal Authority, it appears settled that the power of a tribal government within the boundaries of its non-280 reservation is quite broad because of the tribe's inherent sovereignty, which even extends over non-Indians present within the bounds of the reservation.70/ When a tribe, in the exercise of such sovereignty, regulates activities on the reservation in a way affecting non-Indian transactions thereon, then under Williams v. Lee $71 /$ the State jurisdiction over such matters, which otherwise exists as a result of the cases cited at the beginning of this section, could be substantially curtailed where a Williams "infringement" exists. The Supreme Court, in Thomas v. Gay 72/ relying on Utah and Northern Railway v. Fisher, $73 /$ both seminal cases discussed above at the beginning of this section, noted that the personal property tax imposed by the State on non-Indians had too remote an effect on the Indians to be significant. Additionally, in the Moe case discussed above, the Court, relying on Thomas v. Gay, stated, "We see nothing in this burden which frustrates tribal self-government, see Williams v. Lee, 358 U.S. 217, - • (1959)."74/ In any event, where such State regulation on non-Indian activity undermines, diminishes significantly, conflicts, or interferes with the authority or operations of the tribal government, then such regulation should be found to be an invalid "infringement."

It should be clear, however, that after Moe the determination whether an "infringement" exists can be an exceedingly difficult one in view of the conclusion drawn in that case. The effect on the individual Indian salesperson in Moe was quite significant; in a sense as significant as the State judgment against the individual Indian in Williams v. Lee, which judgment was invalidated.75/ Additionally, in McClanahan, which preceded Moe by a year, the Court stated:

- - To be sure, when Congress has legislated on Indian matters, it has, most often, dealt with the tribes as collective entities. But those entities are, after all, composed of individual Indians, and the legislation confers individual rights. This Court has therefore held that "the question has always been whether the state action infringed on the right of reservation Indians [emphasis by the Court] to make their own laws and be. ruled by them." Williams v. Lee, supra, at 220 . . .76/

States will undoubtedly make attempts to extend jurisdiction based on Moe. Delineation of a clearer line as to the nature of a legally significant "infringement" must attend further judicial developments. Severe problems can be anticipated in the future in these situations in which the State also has jurisdiction. $77 /$ 
In view of the fact that the U.S. Supreme Court has eschewed in a different context the jurisdictional phenomenon of checkerboarding in the Moe case,78/ and in view of recent decisions by this Court upholding tribal integrity and authority, this author believes that eventually the Court will find an "infringement" resulting from State exercises of their concomitant authority over non-Indians on reservations.78a/

In any event, Thomas v. Gay,79/ Utah and Northern Railway,80/ and Moe 81/ have been found by State and Federal courts to justify imposition of State taxes on the income, $82 /$ the gross receipts, $83 /$ and the reservation leasehold interests 84 of non-Indians. The last-mentioned holding turned on the fact that the Indian lessor would never be liable for the tax and the conclusion that the statutory right in the State to seize and sell the property interest assessed may well be invalid as applied. The gross receipts case points out the value of converting as much as is practicable, ideally all but salary, to expenditures by the non-Indian as a agent for the tribe or individual Indians rather than as an independent contractor selling not only services but also materials. In addition, the Federal district court in New Mexico has held that the laws of that State regulating water, liquor sales, and subdivision controls could be applied to a non-Indian owned corporation holding a long-term lease on lands of the Tesque Pueblo. $\underline{85 /}$

Despite some authority to the contrary, the New Mexico Court of Appeals has concluded that a corporation incorporated under State law, which qualifies under Federal law86/ and regulations87/ as an "Indian corporation," would be subject to the McClanahan limits on State jurisdiction applicable to Indians rather than the Moe limits applicable to non-Indians.88/ The corporation in question was owned 49 percent by non-Indians. This holding, although now New Mexico law, is vulnerable in other State court systems and, as a consequence, a source of some security only in New Mexico.

\section{F. Miscellaneous Bases and Limits for State Authority--In General.}

Although there are Federal statutes providing for special treatment for specific tribes in certain circumstances, there are several general provisions the full significance of which has never been tested to any great extent either by State government assertions of authority thereunder and consequently by challenges to such assertions. There are, first, the provisions in the General Allotment Act making the laws of the State applicable to lands which have been conveyed in fee.89/ The second such provision appears generally to vest the States with some authority concerning health and education.90/ The third relates to the taxability by the State of production from "bought and paid for" and executive order lands under several of the earlier Indian lands leasing acts.91/ The fourth is regulatory. In title 25 C.F.R., the Secretary of the Interior asserts the authority to grant power to State and local governments to regulate Indians and their lands.92/ This section concludes with a discussion of the effects of State constitutional and Federal disclaimers on State jurisdiction. 


\section{(1) General Allotment Act.}

With respect to the provision in the General Allotment Act making State law applicable to allottees receiving fee patents,93/ the Solicitor of the Department of Interior opined in 1954 that the States acquired very limited authority hereunder.94/ The criminal cases cited in the ruling and several civil cases indicate that State jurisdiction has been successfully asserted over the patent allottees pursuant to the provision in the General Allotment Act and despite problems with its application.95/ It has been held that the statute of limitations of the State of Montana applied to fee patent lands within the Crow Indian Reservation by reason of the provision in question in the General Allotment Act.96/

The U.S. Supreme Court in the 1976 case of Moe v. Confederated Salish and Kootenai Tribes $97 /$ has concluded that section 349 did not justify imposing personal property and sales taxes and State licensing requirements on reservation Indians who own reservation land patented in fee. Additionally, the decision arguably indicates that the provision in question in the Act has been by implication repealed. The Court stated:

The State instead argues that the District Court failed to properly consider the effect of the General Allotment Act of 1887, 24 Stat. 388, and a later enactment in 1904, 33 Stat. 302, applying that Act to the Flathead Reservation. Section 6 of the General Allotment Act, 24 Stat. 390, as amended, 25 U.S.C. 349, provides in part:

At the expiration of the trust period and when the lands have been conveyed to the Indians by patent in fee. . then each and every allottee shall have the benefit of and be subject to the laws, both civil and criminal, of the state or territory in which they may reside. . .

The state relies on Goudy v. Meath, 203 U.S. 146, 27 S. Ct. 48, 51 L. Ed. 130 (1906), where the Court, applying the above Section, rejected the claim of an Indian patentee thereunder that state taxing jurisdiction was not among the "laws" to which he and his land had been made subject. Building on Goudy and the fact that the General Allotment Act has never been explicitly "repealed," the state claims that Congress has never intended to withdraw Montana's taxing jurisdiction, and that such power continues to the present.

We find the argument untenable for several reasons. By its terms it does not reach Indians residing or producing income from lands. held in trust for the tribe, which make up about one-half of the land area of the reservation. If the General Allotment Act itself establishes Montana's jurisdiction as to those Indians living on "fee patented" lands, then for all jurisdictional purposes--civil and criminal--the Flathead Reservation has been substantially diminished in size. . . 
We concluded that "[s]uch an impractical pattern of checkerboard jurisdiction." id., was contrary to the intent embodied in the existing federal statutory law of Indian jurisdiction. See also United States v. Mazurie, 419 U.S. 544-555, 95 S. Ct. 710, 716-717, 42 L. Ed. 2d 706, 715 (1975).

The State's argument also overlooks what his Court has recently said of the present effect of the General Allotment Act and related legislation of that era:

Its policy was to continue the reservation system and the trust status of Indian lands, but to allot tracts to individual Indians for agriculture and grazing. When all the lands had been allotted and the trust expired, the reservation could be abolished. Unallotted lands were made available to non-Indians with the purpose, in part, of promoting interaction between the races of encouraging the Indians to adopt white ways. See $\$ 6$ of the General Allotment Act, 24 Stat. 390; [citation omitted]. The policy of allotment and sale of surplus reservation land was repudiated in 1934 by the Indian Reorganization Act, 48 Stat. 984, now amended and codified as 25 U.S.C. $\$ 461$ et seq. Mattz v. Arnett, 412 U.S. 481,49693 S. Ct. 2245, 2254, 37 L. Ed. 2d 92, 101 (1973) [part of footnote 18 incorporated into text].

The State has referred us to no decisional authority--and we know of none--giving the meaning for which it contends to $\$ 6$ of the General Allotment Act in the face of the many and complex intervening jurisdictional statutes directed at the reach of state law within reservation lands--statutes discussed, for example, in McClanahan, 411 U.S., at 173-179, 93 S. Ct., at $1262-1266,36$ L. Ed. 2d, at 136-139. See also Kennerly v. District Court of Montana, 400 U.S. 423, 91 S. Ct. $480,27$. L. Ed. 2d 507 (1971). Congress by its more modern legislation has evinced a clear intent to eschew any such "checkerboard" approach within an existing Indian reservation, and our cases have in turn followed Congress' lead in this area.98/

\section{(2) Health and Education.}

The second statute, relating to health and education, appears in its intent to have only limited significance, as a unilateral investiture of authority in State government:

The Secretary of the Interior, under such rules and regulations as he may prescribe, shall permit the agents and employees of any state to enter upon Indian tribal lands, reservation, or allotments therein (1) for the purpose of making inspection of health and educational conditions and enforcing sanitation and quarantine regulations or (2) to enforce the penalties of state 
compulsory school attendance laws against Indian children and parents, or other persons in loco parentis except that this subparagraph (2) shall not apply to Indians of any tribe in which a duly constituted governing body exists until such body has adopted a resolution consenting to such application.99/

Following the often-cited general principle that legislation of Congress is construed if possible in the interest of the Indian,100/ then tribal integrity and sovereignty should be affected only as expressly provided. The very limited authority of this statute is consistent with the above conclusion.101/

\section{(3) State Taxation of Mineral Production.}

Individually owned Indian land which is subject to the trust restrictions under the Allotment Act102/ and homesteads which are purchased out of trust or restricted funds $103 /$ are free from tax, and Indian-owned fee patent land within a reservation is probably also tax-free.104/ However, mineral production from unallotted "bought and paid for" tribal lands and from executive order tribal lands might be subject to State taxation by express Federal authorization.105/ "Bought and paid for" lands include not only "lands acquired by Indians through the payment of a consideration in money, but equally including lands reserved for Indians in return for a cessation or surrender by them of other lands, possessions, or rights."106/ Thus the provisions permitting State taxation of production, if still applicable, would apply quite widely since most tribal lands, including Jicarilla tribal lands, would qualify as either executive order or "bought and paid for" lands. The provision applicable to unallotted "bought and paid for" lands provides as follows:

That the production of oil and gas and other minerals on such lands may be taxed by the state in which said lands are located in all respects the same as production on unrestricted lands, and the Secretary of the Interior is authorized and directed to cause to be paid the tax so assessed against the royalty interests on said lands: Provided, however, that such tax shall not become a lien or charge of any kind or character against the land or the property of the Indian owner.107/

The other above-cited provision which applies to executive order lands 108/ is similar. The solicitor opined in 1955 that the State taxing power existed under section 398 with regard to certain tribal lands in Montana109/ and in 1956 to tribal lands in New Mexico.110/ Then on November 7, $1977,111 /$ the solicitor withdrew the above opinions and concluded that section 398 does not apply to lands leased under the 1938 Leasing Act and as a consequence State taxing power does not exist for the tribe's share of production from such lands.112/ Although the question is not yet settled nationwide, the Federal District Court for the District of New Mexico held on December 29, 1977, in Merrion et a1. v. Jicarilla Apache Tribe et al. in an unpublished opinionl12a/ that the above Federal laws still applied, with the result that tribal mineral production in New Mexico from such lands may indeed be taxed by the State. Because of the importance of this case, a copy of the opinion has been obtained and included in the report as Appendix $C$. This case, decided on somewhat questionable 
grounds, is now on appeal to the Tenth Circuit. See the discussion of this case in Part III, Section II A, infra.

\section{(4) 25 C.F.R. Section 1.4 .}

Numerous other specific provisions in the U.S. statutes at large give special treatment to various groups of Indians under varying circumstances. However, the above constitute three statutes allowing for exercise of some measure of State jurisdiction in a comprehensive fashion over Indian reservations including both P.L. 280 and non-280 reservations. Under title 25 C.F.R., section 1.4, the Secretary of the Interior has assumed the power to make State and local law applicable to Indian property. Title 25 C.F.R., section $1.4113 /$ provides as follows:

(a) Except as provided in paragraph (b) of this Section, none of the laws, ordinances, codes, resolutions, rules or other regulations of any state or political subdivision thereof limiting, zoning or otherwise governing, regulating, or controlling the use or development of any real or personal property, including water rights, shall be applicable to any such property leased from or held or used under agreement with and belonging to any Indian tribe, band, or community that is held in trust by the United States or is subject to a restriction against alienation imposed by the United States. (b) The Secretary of the Interior or his authorized representative may in specific cases or in specific geographic areas adopt or make applicable to Indian lands all or any part of such laws, ordinances, codes, resolutions, rules or other regulations referred to in paragraph (a) of this Section as he shall determine to be in the best interest of the Indian owner or owners in achieving the highest and best use of such property. In determining whether, or to what extent, such laws, ordinances, codes, resolutions, rules or other regulations shall be adopted or made applicable, the Secretary or his authorized representative may consult with the Indian owner or owners and may consider the use of, and restrictions or limitations on the use of, other property in the vicinity, and such other factors as he shall deem appropriate.

As reported in the recent Ninth Circuit case of Santa Rosa Band of Indians v. King's County, 114/ several Federal district courts have refused to apply its provisions because of the lack of specific statutory authorization and therefore because of its invalidity.115/ However, the Santa Rosa case approved the Secretary's exercising his authority under section 1.4, finding specific authority for such in the Indian Reorganization Act of 1934.116/ With this decision, secretarial bestowals of authority on State or local governments, if any "specific" statutory authorization can be found, such as the 1934 IRA, appear feasible even without P.L. 280.117/ 
(5) State Constitutional and Federal Disclaimers of State Authority.

The enabling legislation and the constitution for the State of New Mexico both contain disclaimers of right, title, and governmental authority over Indian lands.118/ Nevertheless, State and Federal authorities have not found these limitations to be absolute.119/ Rather the principles described in this part appear in the enabling legislation for the States of Alaska,120/ Arizona,121/ Idaho,122/ Montana,123/ New Mexico,124/ North Dakota, $\overline{125} /$ South Dakota, 126/ Utah, 127/ Washington, 128/ and Wyoming $129 /$ with undoubtedly the same significance.

G. Specific Applications.

(1) State Court Jurisdiction on a Non-280 Reservation.

(a) Matters Involving Exclusively Indians.

Following upon the discussion above in Section $I C$, a State court in a non-P.L. 280 jurisdiction would not have jurisdiction to hear a matter arising on the reservation which involves exclusively reservation Indians. Even if the plaintiff, a reservation Indian, invoked the jurisdiction of the court, as appears possible, $130 /$ the lack of consent of the defendant would clearly preclude the State from proceeding.131/ Absent Federal court jurisdiction,132/ the appropriate forum for such matters is tribal court. The fact that a particular Indian party is not a member of the tribe located on the reservation would not appear to render such Indian party a non-Indian for purposes of these State jurisdictional questions.133/

\section{(b) Matters Involving Both Indians and Non-Indians.}

For matters arising on a non-P.L. 280 reservation, the principles described immediately above would appear to also apply.134/ If, however, the Indian party consents to the jurisdiction of the state court, the court may possibly acquire the needed subject matter jurisdiction.135/ Absent Federal court jurisdiction, $136 /$ the only other forum for resolution of such disputes is tribal court. Difficulties can arise with non-Indians gaining access to tribal court if the tribal law excludes matters involving non-Indians from the jurisdiction of tribal court. In dictum, however, the Eighth Circuit has indicated that such exclusions may violate the Indian Civil Rights Act of 1968.137/ If this is true, then, despite the limit in the Tribal Code, tribal court would constitute an appropriate forum for such matters.138/ The fact that a particular Indian party is not a member of the tribe located on the reservation would not appear to render such Indian party a non-Indian for purposes of these State jurisdictional questions. 139

\section{(c) Matters Involving Non-Indians.}

For matters arising on a non-P.L. 280 reservation which involve exclusively non-Indians, the State's general rules governing jurisdiction of the person and subject matter would appear to apply.140/ This is to say that for such matters, the courts are not fettered by the jurisdictional limits applicable to matters involving reservation Indians. The fact that a particular Indian party is not a member of the tribe located on the 
reservation would not appear to render such Indian party a non-Indian for purposes of these State jurisdictional questions.141/ The tribal court system should also be available to non-Indian parties for such matters. Tribal codes withholding jurisdiction from the tribal courts for such matters may well be invalid.142/

If a valid judgment in such a suit is obtained, then the Arizona, 143/ New Mexico,144/ and Montanal45/ courts will permit enforcement of that judgment on the reservation if necessary. This is consistent with the seminal U.S. Supreme Court case in this area, i.e., Utah and Northern Railway v. Fisher, 146/ wherein the Court approved of a State's enforcement on the reservation of its tax laws against a non-Indian. This should not be considered precedent, however, for the valid enforcement by State officials of State process or valid judgments against Indians.147/ These judgments would involve, of course, matters arising outside the non-P.L. 280 reservation, i.e., matters not within the scope of this study.

(2) State Environmental Laws on a Non-280 Reservation.

(a) Activities Involving Either Exclusively Indians or Both Indians and Non-Indians.

States have no authority to regulate such operations or activities within the bounds of a non-P.L. 280 reservation independent of Federal authorization and, as a consequence, attempts to do so should prove invalid.148/ Additionally, State environmental laws enacted pursuant to Federal $\overline{l e g}$ islation $149 /$ probably cannot validly affect such operations since these Federal environmental laws do not appear to have bestowed such authority on the States. In view of the current status of "Indian corporations" discussed below in subsection $G(5)$, if a corporation qualifies as such, then the principles discussed in this Part should apply thereby precluding State jurisdiction. The same clearly should be true for partnerships, joint ventures, and sharing arrangements involving both Indians and non-Indians. This is so not only because if these are "Indian owned," i.e., 51 percent or more, then they have an Indian identity despite their being organized under State law, but also because none of these organizations, as contrasted with a corporation, is sufficiently a separate entity in the eyes of the law.150/

\section{(b) Activities Involving Exclusively Non-Indians.}

In the context of environmental law, probably the State of New Mexico and others will attempt to assert the authority over non-Indian activities.151/ If such authority exists independently under Utah \& Northern Railway, 152/ Moe, 153/ and Warren Trading Post, 154/ then the Federal environmental. regulations would not appear to preclude or proscribe State jurisdiction.155/ Then the question is whether the above cases permit such jurisdiction. Since the Federal environmental legislation contemplates State regulation where the State is willing and otherwise has the authority to do so, it is unlikely that Warren Trading Post would be held to bar State regulation of such activities. However, Moe and its line of precedent applying the "infringement" test may arguably preclude the State's involvement because the latter would constitute an "infringement" on tribal 
government authority. It would seem that State regulation in this context would have a more direct and substantially greater effect on all of these residents of the reservation than any of the State activities held not to constitute an "infringement" in the Moe line of cases. Nevertheless, there simply is no definitive answer that can be given to this question at this time. In any event, the Federal statutes and regulations prescribe minimum standards which will apply, absent tribal or state standards which are at least as strict.

(3) State 0il and Gas and Other Mineral Conservation Laws on a Non-P.L. 280 Reservation.

(a) Matters Involving Exclusively Indians or Both Indians and Non-Indians.

Based on McClanahan, 156/ Fisher v. District Court, 157/ and that line of cases, the State is clearly foreclosed from regulating such matters.

(b) Matters Involving Exclusively Non-Indians.

Because of the comprehensive regulation of such matters by the Federal government, 158/ Warren Trading Post 159/ would rather clearly dictate that the State is preempted from regulating in this context. This conclusion is borne out by several Federal district court decisions.160/

(4) State Law Governing Property Rights, Zoning, Criminal Activity, and Other Miscellaneous Non-Tax Matters.

(a) Matters Involving Exclusively Indians or Both Indians and Non-Indians.

Recording laws, zoning laws, laws governing water rights, and other State laws governing business or personal transactions should not apply on non-P.L. 280 reservations $.161 /$

(b) Matters Involving Exclusively Non-Indians.

In general, State law would appear applicable unless there is a Williams-Moe "infringement" or a Federal preemption by Federal law as in Warren Trading Post.162/ Under the latter holding, if the Federal Government has regulated extensively with regard to particular non-Indian activities, then the State is facing the obstacle of being preempted. Under Williams and Moe, the State regulation could have no effect on any underlying Indian property interest.163/ Additionally, such State regulation very possibly would be invalid to the extent that it required or effected a change of ownership in non-Indian owned property rights if an Indian or a tribe also owns an interest in such property, whether future or concurrent. This is particularly so where Federal regulations require Federal consent for such non-Indian transfers or assignments.164/

Nevertheless, the problems of checkerboarding, which the Supreme Court has eschewed in different contexts,165/ would or could realistically arise in the extreme in this Moe-Williams context.166/ Two developments appear 
likely to this author: First, this Moe-Williams question will again go to the U.S. Supreme Court and, second, in view of all of the decisions of that Court confirming tribal integrity and authority, the Court will find an "infringement" in these double jurisdiction cases.166a/

In any event, both tests provided by the courts thus far are not easily applied to most situations. As a consequence, continued State regulation in a variety of contexts involving exclusively non-Indians can be anticipated. In New Mexico, as noted above in subsections $E$ and $G(2)(b)$, the State has asserted, so far successfully, that its zoning, liquor, water, environmental, and tax laws apply to such matters. Additionally, as discussed above in subsection $G(1)(c)$, so far valid state court judgments concerning such matters would appear enforceable by New Mexico State officials on reservations.

\section{(5) Corporations and Other Business Organizations.}

\section{(a) Corporations.}

If in general the corporation is incorporated under State law, then such organization thereby will acquire a non-Indian identity and therefore be subject to State law as a separate legal person.167/ This is subject to the qualification in New Mexico that if the corporation is 51 percent or more owned by Indians on whose reservation the corporation is carrying on business, such corporation will be treated as an Indian entity. In such case, the corporation would qualify as an "Indian corporation." $168 /$

If. the corporation is incorporated under tribal law, then it should have an Indian identity if 51 percent or more of the stock is owned by Indians. Even if a corporation is completely owned by non-Indians, it is arguable that it has an Indian identity because of the location of its incorporation. However, in view of the willingness of the New Mexico Court of Appeals to look through the corporation to its shareholders, 169/ such probably would not be viable in New Mexico.

As long as the corporation is owned to some extent by Indians, even though not 51 percent, and if the willingness to look through the corporation to the shareholders persists in the New Mexico courts, then it would seem that the Kennerly line of cases discussed above in subsection $D$ 170/ would apply. As a consequence, the State would not appear to have regulatory or taxing authority over it. This argument would appear viable even though the corporation is incorporated under state law and does not qualify as an "Indian corporation" because of the minority percentage of Indian ownership.

There are two caveats to these conclusions: First, to the extent the corporation conducts activities of the reservation, it will be treated like any other person subject to the laws of the State unless the State is specifically preempted from doing so by Federal law.171/ Second, the conclusions drawn by the New Mexico Court of Appeals, $172 /$ upon which the above comments were based, may well not be followed in other jurisdictions.173/ 
The Jicarilla Apache Tribe received a charter as Federal corporation on June 16, 1960, under the 1934 Indian Reorganization Act (IRA).173a/ Congress contemplated that the IRA chartered corporations would provide a vehicle for the tribes to conduct business. This corporation is and must remain wholly owned by the tribe. It is immune from suit except to the extent otherwise provided in the charter. The Jicarilla charter immunizes all corporate property but that specifically pledged or assigned. It seems clear that such corporation would be immune from State tax law, except perhaps for mineral production taxes discussed immediately below. In addition it should be immune from Federal income taxes, since it constitutes the federally established business arm of the Tribe and should have, therefore, the exemption that the Tribe has for the same income.

\section{(b) Other Business Organizations.}

Any business organization owned 51 percent or more by Indians would qualify as an Indian "economic enterprise"174/ and according to current New Mexico law would be treated as an Indian venture.175/ Additionally, however, joint ventures, partnerships, and sharing or co-owner arrangements have no distinct legal personalty or identity apart from the owners.176/ As a consequence, if such an enterprise is owned in any part by an Indian, then the Kennerly rule discussed above in Section $D 177 /$ should apply, thereby precluding State regulatory and taxing authority even if the enterprise is organized under State law.

\section{(6) State Tax Laws on a Non-280 Reservation.}

(a) "Bought and Paid For" and Executive Order Tribal Lands.

In view of the discussion above in subsection $F(3), 178 /$ the Jicarilla tribal lands probably qualify as either "bought and paid for" or executive order lands. The question of whether production from this land is taxable must receive further judicial determination. One can reasonably anticipate assertions of authority by the States to tax mineral production on this basis.

\section{(b) Matters Involving Exclusively Indians or Both Indians and Non-Indians.}

Absent applicability of the special legislation discussed immediately above, such matters should be immune from State taxation.179/ The conclusion would appear identical with regard to production from a P.L. 280 reservation. $180 /$

(c) Matters Involving Exclusively Non-Indians.

Such matters on a non-P.L. 280 reservation should be subject to taxation as long as Indian interests are not directly affected or there is a preemption based on the Warren Trading Post decision.181/ The fact that an Indian individual is responsible for collecting the tax should not affect this conclusion, 182/ as long as the burden of the tax is not imposed on such 
person.183/ Additionally, the fact that the tribal or individual Indian competitive advantage over extra-reservation business concerns is reduced because the Indian inability to market a tax exemption is not, in the view of the Ninth Circuit, a legally significant "infringement" under the Williams test.184/

If, however, the tax constitutes an encumbrance or lien on Indian property interests (probably true even if the tax is a lien or encumbrance on the interest of the non-Indian taxpayer or if an Indian also has an interest, e.g., a reversionary interest after a lease), then at least to the extent of such lien or the enforcement provisions, the tax is probably invalid.185/

Additionally, it is important to keep in mind the facts of the Warren Trading Post case, d1scussed above, 186/ i.e., a sales tax on receipts of a trading post operator. The Court held, it should be recalled, that because of the complete Federal regulation of such operations the State was preempted from exercising taxing authority despite the general rules otherwise allowing State authority over non-Indians. Because of the exhaustive Federal regulation of mineral operations by non-Indians, it appears reasonably arguable that the Warren conclusion should be drawn in this context as well. Nevertheless, it is likely that States will assert such authority unless and until told otherwise by the judiciary.

\section{(7) Tax and Business Planning.}

(a) In General.

As noted above, State law will not apply to affect Indian enterprises or interests on a non-P.L. 280 reservation except under one of the special provisions discussed above in subsection $F$. As a consequence, it is in those transactions or activities involving non-Indians where the impact of State law may be felt. If it is determined desirable to avoid some aspect of State law, then the following may provide the means to accomplish this end with the resulting benefits being allocated between or among the parties according to the agreement struck between them.

\section{(b) State Tax Laws.}

\section{(i) Income and Gross Receipts Taxes.}

Income taxes and gross receipts taxes apply to the funds received by a non-Indian.187/ To the extent that the amount of such funds is minimized, the impact of the tax will be minimized. If the non-Indian is to serve merely as a contractor, then the transaction should be framed so that the contractor receives only outright and unrestricted funds for services. For any materials to be acquired, it should be provided that the non-Indian contractor is spending tribal monies as an agent for the tribe. If the vehicle of an "Indian corporation" is used,188/ i.e., that the contractor is to be a corporation owned 51 percent or more by Indians, then only actual distributions to the non-Indian contractor would appear to be so taxable. 
If the corporation is incorporated only under tribal law, then despite only a minority Indian ownership, it probably would be successful in the above respect.

If the non-Indian is to be a principal or venturer with Indians, then an "Indian corporation" $189 /$ would probably be successful in sheltering all income except actual distributions to the non-Indian participants, at least. in New Mexico. If the corporation is incorporated only under tribal law, it should also be effective.

\section{(ii) Sales Taxes.}

If sales taxes are imposed on the seller, then the seller should be an Indian person or entity in order to escape such taxes. If sales taxes are imposed on a purchaser with the seller acting as agent for the State in collecting the tax, then probably for sales to non-Indians, such tax is enforceable despite the seller's qualifying as an Indian.190/

\section{(iii) Property Taxes.}

With regard to property taxes, if a non-Indian is to be a co-owner, then in New Mexico the only certain means of sheltering such property from tax is through an "Indian corporation."191/ The shares of stock owned by non-Indians, however, probably would not escape State property taxes.

\section{(iv) Caveats.}

There are several caveats to the conclusions drawn above: First, an "Indian corporation" which is incorporated under State law may not he. accorded the same treatment in other States which it is accorded so far in New Mexico.

Second, organizations which do not constitute separate entities in the eyes of the law, e.g., partnerships, joint ventures, sharing and co-owner arrangements, leave the non-Indian participant(s) exposed.192/ In such arrangements, of course, the "infringement" test193/ is arguably a bar as well as the Kennerly principle.194/ As discussed above, generally the "infringement" principle is applicable to matters involving exclustvely non-Indians; the Kennerly principle is applicable to matters involving both Indians and non-Indians. Because income taxes are imposed on individual persons, whether natural or corporate, the income tax burdens of a State probably could be validly imposed on the non-Indian venturer in one of the above enterprises. It would seem, however, that the other taxes are levied. against acts or property. As a consequence, when both Indians and nonIndians are involved in such acts or both are concurrent owners of such property, then the tax involved is directed against both. If such is true, then the more restrictive rule of Kennerly ought to apply with the result that such a State attempt to tax is invalid.195/ As noted above, if the activity is conducted, the property is owned, or the income is earned by an Indian person, i.e., an "Indian corporation," then somewhat more certainty exists that the State has no authority. 
Third, a wholly Indian-owmed corporation may not be entitled to the same Federal income tax immunity to which an Indian tribe is entitled.196/ However, as discussed above in subsection $G(5)$, the Jicarilla IRA corporation should be exempt from Federal income tax. A revenue ruling should be obtained on the question if the Federal tax exemption is crucial. A careful analysis of both the potential costs and risks may dictate the creation of a partnership, with the Tribe possibly retaining its Indian identity for Federal income tax purposes and, therefore, its Federal tax immunity. The tribe may still be able to rely on Kennerly for protection from State taxes on all income except that allocable to non-Indians, including the partnership interests owned by non-Indians for property tax purposes.

\section{(v) State Regulations.}

Planning to control State nontax regulations is subject to the same limits. If a non-Indian is conducting the activity exclusively, then the principles discussed above in subsection $E$ apply. The result is that State law governs unless an "infringement" or a Warren Trading Post preemption can be shown. If both Indians and non-Indians are involved in the activity then the Kennerly principle discussed in subsection $D$ should apply with the result that the activity is probably immune from State authority. The safest way of providing two levels of protection is through an "Indian corporation" discussed above in subsections $C$ and $G(5)$. 
FOOTNOTES

APPENDIX A, PART II

1. 31 U.S. (6 Pet.) 515 (1832).

2. Id. at 561 .

3. $\overline{104}$ U.S. $621(1881)$.

4. 18 U.S.C. $\$ 1153$.

5. Draper v. United States, 164 U.S. 240 (1896); Ray v. Martin, 326 U.S. 496 (1959).

6. See Arizona ex rel. Merrill v. Turtle, 413 F.2d 683 (9th Cir. 1969), cert. denied, 396 U.S. 1003 (1970), wherein the right of the Navajo Tribe to refuse to extradite an Indian to the State, even though the Indian was not a Navajo, was upheld. This result arguably resurrects the notion of geographical sovereignty.

A New Mexico Court, however, recently construed the Turtle case in a way consistent with McBratney and Gay, holding that if a person is an Indian and resides on a reservation--whether or not he or she is a member of the tribe to which the reservation belongs--the person is immune from State authority for intrareservation matters in, of course, a non-P.L. 280 State. Mary Jo Fox v. Bureau of Revenue of the State of New Mexico, 531 P.2d 1234 (N.M. Ct. App. 1975).

7. 116 U.S. 28.

8. Accord: Maricopa \& Phoeniz Railroad v. Arizona, 156 U.S. 347 (1895); Thomas v. Gay, 169 U.S. 264 (1898); Waggoner v. Evans, 170 U.S. 588 (1898); Catholic Missions v: Missoula County, 200 U.S. 118 (1906); Surplus Trading Co. v. Cook, 281 U.S. 647 (1930).

8a. Act of 8-15-53, Ch. 50567 Stat. 589-90, codified as amended at 18 U.S.C. $\$ 1162 \mathrm{et} \mathrm{seq}$. and 28 U.S.C. $1360 \mathrm{et}$ seq.

8b. Act of 8-8-58, P.L. $85-615, \$ 2,72$ Stat. 545 .

$8 c .25$ U.S.C. $\$ 1301-1303,1311-1312,1321-1326,1331,1341$.

9. Williams v. Lee, 358 U.S. 217 (1959); Organized Village of Kake v. Egan, 369 U.S. 60 (1962); Warren Trading Post Co. v. Arizona Tax Comm'n, 380 U.S. 685 (1965); Kennerly v. District Court, 400 U.S. 423 (1971); McClanahan v. Arizona. Tax Comm'n, 411 U.S. 164, 93 S. Ct. 1257 (1973); Mescalero Apache Tribe v. Jones, 411 U.S. 145, 93 S.Ct. 1267 (1973); United States v. Mason, 412 U.S. 391, 93 S. Ct. 2202 (1973); United States v. Mazurie, 419 U.S. 54495 S.Ct. 710, (1975); Fisher v. District Court of the Sixteenth Judicial District of Montana, 42 U.S. 382, 96. S. Ct. 943 (1976); Moe v. Confederated Salish and Kootenai Tribes, 425 U.S. 463, 96 S. Ct. 1634 (1976).

10. See the text, infra, to which note 15 et seq. is appended. 
11. Williams v. Lee, note 9, supra.

12. Organized Village of Kake v. Egan, note 9, supra (dictum).

13. Kennerly v. District Court, note 9, supra.

14. Compare Williams v. Lee with Kennerly ve District Court, note 9, supra.

15. 358 U.S. 217 (1959).

16. Id. at 219-220.

17. $\overline{\text { Id. }}$ at 223.

18. State ex rel. Iron Bear v. District Court, 512 P. 2d 1292

(Mont. 1973); Nativa v. Nativa, 499 P.2d 691 (N.M. 1972); McClanahan v. State Tax Comm'n 484 P. 2d 221 (Ariz. 1971).

19. Smith v. Temple, 152 N.W.2d 547 (S.D. 1967); State ex rel. Adams v. Superior Court, 356 P. 2d 985 (Wash. 1960).

20. 369 U.S. $60(1962)$.

21. Id. at 75 .

22. 400 U.S. 423.

23. 411 U.S. 164.

24. 484 P. 2d 221, 222 (1971).

25. 4 U.S.C. $\$ 104$ et seq.

26. 36 Stat. $557, \overline{569}(1910)$.

27. 411 U.S., at 178; the Court notes, however, in a footnote, "We do not suggest that Arizona would necessarily be empowered to impose this tax had it followed the procedures outlined in [P.L. 280]. That question is not presently before us, and we express no views on it."

411 U.S., at 179.

29. 411 U.S., at 171 .

30. 411 U.S., at 181 .

31. 424 U.S. 382,96 . S.Ct. 943.

32. 425 U.S. 463,96 S.Ct. 1634 (1976).

33. See the discussion, infra, Part II, Section I E, on exclusively non-Indian matters.

34. 25 U.S.C. $\$ 349$.

35. 25 U.S.C. $\$ \$ 398,398$ c.

36. 25 U.S.C. $\$ 231$.

37. Tribal government often adopts in part State law.

38. This is so unless the defendant is served with process of $f$ the reservation.

39. 25 U.S.C. \$1322.

40. Fisher v. District Court of Sixteenth Judicial District of Montana, 424 U.S. 382, 96 S. Ct. 943 (1976). See also, Annis v. Dewey County Bank, 335 F. Supp. 133 (D.S.D. 1971); Wisconsin Potowatomies of Hannahville Indian Community v. Houston, 393 F. Supp. 719, 733 (W.D. Mich. 1973); Wakefield v. Little Light, 2 Ind. L. Reptr., \#12, p. 26 (Md. Ct. App. 1975). For an explanation of subject matter Jurlsdlclion, sec Van Mehren and Tralltman, "Jurisdiction to Adjudicate: A Suggested Analysis," 79 Harv. L. Rev. 1121 (1966).

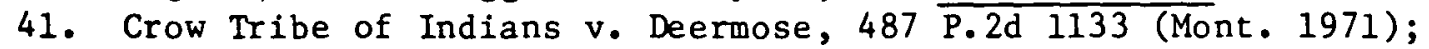
Security State Bank v. Pierre, 511 P.2d 325 (Mont. 1973).

42. Wanneka v. Campbell, 526 P.2d 1085 (Ariz. 1974).

43. Mary Jo Fox v. Bureau of Revenue of New Mexico, 531 P.2d 1234 (N.M. Ct. App. 1975), cert. denied, 44 U.S.L.W. 3469, 3473 (3-24-76), wherein the income of a Comanche Indian earned on the Navajo 
reservation was held immune from State taxation. The New Mexico State court went on to conclude that the particular tribal affiliation of the individual made no difference as long as the status as an Indian and the location on a reservation were established facts. Accord: Chino v. Chino, 4 Ind. L. Reptr. G-24 (N.M. S.Ct. 1977); Idaho State Tax Comm'n v. Mehojah, 3 Ind. L. Reptr. h-13 (Idaho Dist. Ct., Ada County 1976).

44. United States v. State Tax Comm'n of Miss., 505 F.2d 633.

45. Eastern Navajo Industries, Inc., v. Bureau of Revenue of New Mexico, 552 P. 2d 805 (1976).

46. Id. at 809 .

47. $\overline{25}$ U.S.C. $\$ \$ 1451,1521$.

48. 25 C.F.R. 80.1 .

49. Ibid.

50. 25 C.F.R. $\$ 80.12$.

51. 358 U.S. 217 (1959).

52. Id. at 219-220.

53. 400 U.S. 423 (1971).

54. 25 U.S.C. \$\$1321-1326.

55. Accord: Mahoney v. Idaho Tax Comm'n, 524 P. 2d 187 (Idaho 1974), cert. denied, 419 U.S. 1089 (1974). As discussed in the next section, the line between State actions which "infringe" on Indian self-government and which are preempted by P.L. 280 under the Kennerly holding, on the one hand, and those which have a significant effect only on non-Indians, on the other hand, is more difficult to discern after the 1976 U.S. Supreme Court decision of Moe v. Confederated Salish \& Kootenai Tribes, 425 U.S. 463, 96 S. Ct. 1634 (1976), wherein the Court held that a State may require independent of P.L. 280 that a reservation Indian collect a cigarette tax on sales to non-Indians on the reservation where the tax is considered a user tax imposed on the purchaser. See the discussion in the next section.

56. Annis v. Dewey County Bank, 335 F. Supp. 133 (D.S.D. 1971); Wakefield v. Little Light, 2 Ind. L. Reptr., 非2, p. 26 (Md. Ct. App. 1975); Enriquez v. Superior Court of State of Arizona, 4 Ind. L. Reptr. 6-15 (Ariz. Ct. App. 1977); Chino v. Chino, 4 Ind. L. Reptr. G-24 (N.M. S. Ct. 1977); see also, Fisher v. District Court for the Sixteenth Judicial District of Montana, 96 S. Ct. 943 (1976). For an explanation of subject matter jurisdiction, see Van Mehren and Trautman, "Jurisdiction to Adjudicate: A Suggested Analysis," 79 Harv. L. Rev. 1121 (1966).

57. Felix v. Patrick, 145 U.S. 317, 332 (1892) (dictum); Adoption of Firecrow v. District Court, 536 P.2d. 190 (Mont. 1975), rev'd on other grounds, 96 S. Ct. 943 (1976); Department of the Interior, Federal Indian Law (1966), p. 363.

58. Security State Bank v. Pierre, 511 P.2d 325 (Mont. 1973). See, however, Woodtick v. Crosby, 544 P.2d 812 (Mont. 1976).

59. See Schantz v. White Lightning, 502 F.2d 67 ( 8 th Cir. 1974).

60. 25 U.S.C. $\$ 1302(8)$. See the discussion in Part I, Section IIIB.

61. Schantz v. White Lightning, 502 F.2d 67 (8th Cir. 1974).

62. 104 U.S. 621 (1881). 
63. Draper v. United States, 164 U.S. 240 (1896); Ray v. Martin, 326 U.S. 496 (1959); State of Nevada v. Jones, 546 P. 2d 235 (Nev. S. Ct. 1976).

64. 116 U.S. 28 (1885). See also, Maricopa \& Phoenix Railroad v. Arizona, 156 U.S. 347 (1895); Thomas v. Gay, 169 U.S. 264 (1898); Waggoner v. Evans, 170 U.S. 588 (1898); Catholic Missions v. Missoula County, 200 U.S. 118 (1906).

65. 411 U.S. 164 (1973).

66. Id. at 171 .

67. $\overline{425}$ U.S. 463,96 S. Ct. 1634.

68. 380 U.S. 685 .

69. 380 U.S., at 691 .

70. United States v. Mazurie, 419 U.S. 544 (1975), wherein the Court stated, at 558 :

Cases such as Worcester, supra, and Kagama, supra, surely establish the proposition that Indian tribes within "Indian country" are a good deal more than "private, voluntary organizations," and they thus undermine the rationale of the Court of Appeals' decision. The se same cases in addition make clear that when Congress delegated its authority to control the introduction of alcoholic beverages into Indian country, it did so to entities which possess a certain degree of independent authority over matters that affect the internal and social relations of tribal life. Clearly the distribution and use of intoxicants is just such a matter. We need not decide whether this independent authority is itself sufficient for the Tribes to impose Ordinance no. 26. It is necessary only to state that the Congress' decision to vest in tribal councils this portion of its own authority "to regulate Commerce. . . with the Indian tribes." cf. United States v. Curtiss-Wright Export Corp., supra.

The fact that the Mazuries could not become members of the tribe, and therefore could not participate in the tribal government, does not alter our conclusion. This claim, that because respondents are non-Indians Congress could not subject them to the authority of the Tribal Council with respect to the sale of liquor is answered by this Court's opinion in Williams v. Lee, 358 U.S. 217,79 S. Ct. 269 , 3 L. Ed. $2 d$ 351 (1959). In holding that the authority of tribal courts could extend over non-Indians, insofar as concerned with transactions on a reservation with. Indians, we stated: 
"It is immaterial that respondent is not an Indian. He was on the Reservation and the transaction with an Indian took place there. [Citations omitted.] The cases in this Court have consistently guarded the authority of Indian governments over their reservations. Congress recognized this authority in the Navajos in the Treaty of 1868, and has done so ever since. If this power is to be taken away from them, it is for Congress to do it. Lone Wolf v. Hitchcock, 187 U.S. 553, 564-566, 23 S.Ct. 216, 220-221, 47 L. Ed. 299." 358 U.S., at 223,79 S.Ct., at 272. (See also Talton v. Mayes, 163 U.S. 376 1896; Morris v. Hitchcock, 194 U.S. 384 [1904].)

71. 358 U.S. 217 (1959), which is discussed, in the text, supra, to which notes $15-17$ are appended.

72. 169 U.S 264 (1898).

73. 116 U.S. 28 (1885).

74. $96 \mathrm{~s}$. Ct., at 1646. One might have concluded before Moe that a State's power to force a reservation Indian to collect the tax albeit ostensibly imposed on the purchaser constituted a Williams "infringement." However, the Court in Moe distinguished Warren Trading Post involving, as noted above, a gross receipts tax on a trading post proprietor and concluded that no Williams infringement existed, as follows, at p. 1645:

However, that case [Warren Trading Post] involved a gross income tax imposed on the on-reservation sales by the trader to reservation Indians. Unlike the sales tax here, the tax was imposed directly on the seller, and, in contrast to the Tribe's claim, there was in Warren no claim that the State could not tax that portion of the receipts attributable to on-reservation sales to non-Indians.

75. See the text, supra, to which notes $15-17$ are appended for a discussion of the case.

76. McClanahan v. Arizona, 411 U.S. 164, 181 (1973). See also note, "Tribal Power to Tax Lessees," 124 U. Pa. L. Rev. 491 (1975); Dolan, "State Jurisdiction over Non-Indian Mineral Activities on Indian Reservations," 52 N.D. L. Rev. 266 (1975).

77. See G.T.E. Gonzalez, "Indian Sovereignty and the Tribal Right to Charter a Municipality for Non-Indians: A New Perspective for Jurisdiction on Indian Land," 7 N.M. L. Rev. 153 (1977).

78. 96 S. Ct., at 1643-1644 (1976); See the quote, subsection $F(1)$, infra. See also Seymore v. Superintendent, 368 U.S. 351, 358 (1962).

78a. See Confederated Tribes of the Colville Indian Reservation v. The State of Washington, 5 Ind. L. Reptr. F-46 (E.D. Wash. 1978), wherein such as "infringement" was found because of overlapping tribal and State taxes.

79. 169 U.S. 264 (1898). 
80. 116 U.S. 28 (1885).

81. Note 67 , supra.

82. Kahn v. Arizona Tax Comm'n, 490 P.2d 846 (1971), cert. denied, 411 U.S. 941 (1973).

83. Mescalero Apache Tribe v. O'Cheskey, 4 Ind. L. Reptr. F-134 (D.N.M. 1977).

84. Fort Mohave Tribe v. County of San Bernardino, Calif. 3 Ind. L. Reptr. e-61 (9th Cir. 1976), cert. denied, 45 U.S.L.W. 3705 $(4-26-77)$.

85. Norvell v. Sangre de Cristo Development Co., 372 F. Supp. 348 (D.N. 1974), rev'd on other grounds, 419 F.2d 370 (10th Cir. 1975).

86. 25 U.S.C. $\$ 1451,1521$.

87. 25 C.F.R. $\$ 80.1$.

88. Eastern Navajo Industries, Inc. v. Bureau of Revenue of New Mexico, 552 P.2d 805 (1976). See, however, United States v. State Tax Comm'n of Mississippi, 505 F.2d 633 (5th Cir. 1974). See also the text, supra, to which notes 44-50 are appended.

89. 25 U.S.C. $\$ 349$.

90. 25 U.S.C. $\$ 231$.

91. 25 U.S.C. $\$ \$ 398,398$ c.

92. 25 C.F.R. $\$ 1.4$.

93. [A]t the expiration of the trust period and when the lands have been conveyed in fee.. . then each and every allottee shall have the benefit of and be subject to the laws, both civil and criminal, of the state or territory in which they may reside. . ." 25 U.S.C. $\$ 340$.

94. The second specific question is whether an Indian, having received a patent in fee to his allotment, becomes subject to the laws, both civil and criminal, of the state in which he resides, notwithstanding the fact that he may come into the possession of other trust lands. The answer to this question would seem to depend upon how Section 6 of the General Allotment Act of February 8, 1887, as amended by the act of May 8,1906 , is read in the light of various circumstances under wich the question might arise. Section 6 , as amended, declares that the expiration of the trust period and when the lands have been conveyed to the Indians by patient in fee "then each and every allottee shall have the benefit of and be subject to the laws, both civil and criminal, of the state or territory in which they may reside***." In the first place, the allotment for which the patent in fee has been issued must have been made pursuant to the General Allotment Act, or some other allotment act, which embodies its provisions by reference. See Celestine v. United States, 215 U.S. 278 (1909), and Eugene Sol Louis v. United States, 274 Fed. 47 (9th Cir. 1921), There are, however, many allotments which have not been so made. In the second place, the patent in fee must have been issued to the original allottee rather then to an heir of the allottee. The Department has held that an Indian who holds an allotment by inheritance or devise does not become subject to the criminal laws of the state of his residenc when a patent in fee has been issued to him, See 58 I.D. 455, and the sam conclusion would seem to hold with respect to the civil laws of the state of his residence. A contrary conclusion was reached in People v. Pratt, P.2d 87 (Calif.). However, the court based its decision on the provision of the General Allotment Act, as amended, relating to the issuance of patents in fee to "allottees." The act of 1910, as amended, which 
authorizes the issuance of patents in fee to heirs, and which contains no declaration that the issuance of the patent shall subject the patentee to the laws of the state, was neither mentioned nor discussed. In the third place, it would seem logical to hold that as long as part of an original allotment is still held in trust by the United States for an allottee, he is not subject to the civil or criminal laws of the state of his residence even though a patent in fee has been issued to him for the remainder of his allotment. There appears, however, to be neither departmental nor judicial decisions on this point, possibly because the issuance of a patent in fee for part of an allotment has not been too frequent. In the fourth place, the allottee to whom a patent in fee has been issued for the whole of his original allotment may subsequently receive another allotment in trust by neither inheritance nor devise but by virtue of the enactment of a statute providing for additional allotments from the surplus lands of the tribe. In State v. Munroe, 274 Pac. 840 (Supp. Ct. Mont., 1929), the court held that a Blackfeet Indian who had been allotted under the act of March 1, 1907 (34 Stat. 1035), and received a patent in fee for this allotment, was subject to State criminal jurisdiction, notwithstanding the fact that he had subsequently received a trust allottment of surplus lands under the act of June 30, 1919 (41 Stat. 16).

While, on the basis of the decided case, it is my conclusion that when an Indian to whom a trust patent has been issued under the General Allotment Act receives a patent in fee for the whole of his allotment he becomes subject to the laws, both civil and criminal, of the State of his residence, notwithstanding the fact that he may subsequently come into the possession of other trust lands by inheritance, devise, or further allotment of surplus lands, an important qualification must be attached to his conclusion, namely that he would not be subject to State jurisdiction with respect to those matters which are reserved to Federal jurisdiction by Federal statutes. For example, if such an Indian inherited an interest in a trust allotment, the interest would still be subject to probate by the Secretary of the Interior under the act of June 25, 1910, supra. Moreover, such an Indian, if he committed in the Indian country against the person or property of another Indian, or other person, one of the crimes specified in the so-called Major Crimes Act (now 18 U.S.C., Sec. 1153), would be subject to prosecution in the Federal courts. Prior to the revision of the Federal criminal code by the act of June 25, 1948 (62 Stat. 757), the governing provision on major crimes by Indians was 18 U.S.C., Sec. 548, which was not entirely clear on the question whether an Indian who committed one of the major crimes against the person or property of another Indian on fee-patented lands within the exterior boundaries of an Indian reservation was subject to prosecution in the Federal rather than the State courts. Federal jurisdiction was denied in the cases of Eugene Sol Louie v. United States, supra, and State v. Johnson, 249 N.W. 284 (Wis. 1933), and upheld in United States v. Frank Black Spotted Horse, 282 Fed. 349 (D.C.S.D., 1922). The Department, in a letter dated November 20, 1942 to the Attorney General of the United States, espoused Federal jurisdiction. Whatever doubt existed seems to have been removed in the revision 
of the criminal code, which provides for Federal jurisdiction in such cases. 18 U.S.C., Sec. 1151, defines the term "Indian country" as including all lands within the limits of any Indian reservation under the jurisdiction of the United States Government, notwithstanding the issuance of any patent**." See State ex rel. Irvine v. District Court, 239 P.2d 272 (Supp. Ct. Mont. 1951).

Such complexities and distinction as these have rendered the grant of State jurisdiction over Indians contemplated by the General Allotment Act largely ineffective. The sponsors of that legislation assumed that the allotment of the Indians in severalty would be but the prelude to the termination of their tribal relations and the liquidation of Federal supervision over them. When that program failed to be carried out, and the Indians, despite the fact that they were now citizens, continued to maintain their tribal relations and the Government continued its guardianship over them, the subjection of the Indians to the jurisdiction of the States ceased to have much reality. State law enforcement officers could not, after all, go around with tract books in their pockets, and being unable to distinguish a patent-in-fee Indian from a ward Indian, they did not commonly concern themselves with law violations by Indians. This, at least, is the impression gathered from the reported cases. There are relatively few cases in which Indians have been subjected to state jurisdiction for the violation of state criminal laws because they were patent-in-fee Indians. See, in addition to the cases already mentioned, In re Now-ge-zhuck, 76 Pac. 877 (Kans. 1904), involving a breach of the peace; Kitto v. State, 152 N.W. 380 (Nebr. 1915), involving assault; State v. Big Sheep, 243 Pac. 1067 (Mont., 1926), involving unlawful possession of [sic] peyore; State v. Bush, 263 N.W. 300 (Minn., 1935), involving trapping muskrat in closed season; People v. Pratt, 80 P.2d 87 (Calif. 1938) involving illegal possession of metal knuckles; United States ex rel. Marks.v. Brooks, 32 F. Supp. 422 (D.C.N.D. Ind., 1940), involving unlawful possession of raccoon and the theoretical jurisdiction of the states thus fell into innocuous desuetude. Thus, when it has been desired to confer on particular states criminal or civil jurisdiction over Indians, it has been accomplished by general statutes conferring such jurisdiction, irrespective of the tenure by wich Indians held their lands. See the acts of June 8, 1940 (54 Stat. 249), applicable to Kansas; May 31, 1946 (60 Stat. 299), applicable to the Devils Lake Reservation, North Dakota; June 30, 1948 (62 Stat. 1161), applicable to the Sac and Fox Reservation in Iowa; July 21, 1948 (62 Stat. 1224), applicable to New York; October 5, 1949 (63 Stat. 705), applicable to tha Agua Caliente Reservation, California; and finally the act of August 15, 1953 (67 Stat. 588), applicable to California as a whole, Minnesota (except Red Lake), Nebraska, Oregon (except Warm Springs), and Wisconsin (except Menominee). The last-mentioned statute also contains a general provision giving the consent of the United States to the assumption by any other state of the Union of civil and criminal jurisdiction over Indians, 61 I.D. 298, 302-304 (1954). 
95. See Bonds v. Sherburne Mercantile, 169 F.2d 433 (9th Cir. 1948), cert. denied, 335 U.S. 899; Moore v. Wa-Me-Go, 83 Pac. 400 (Kan. 1905).

96. Dillon v. Antler Land Co. of Wyola, 507 F.2d 940 (9th Cir. 1974), cert. denied, $95 \mathrm{~S}$. Ct. 1998. See also Woodtick v. Crosby, 544 P. 2d 812 (Mont. 1976) (deciding that the State courts had subject matte $r$ jurisdiction in suits involving such land); Nahglenethdespah Jake v. Elkins, 2 Ind. L. Reptr., \#5, p. 10 (10th Cir. 1975) (the State's statute of limitations was held applicable).

97. 425 U.S. 463, 96 S. Ct. 1934 (1976).

98. $96 \mathrm{~S}$. Ct., at 1643-1644.

99. 25 U.S.C. $\$ 231$.

100. United States v. Celestine, 215 U.S. 278 (1909); Red Bird v. United States, 203 U.S. 76 (1906); see also 34 Op. A. G. 439 (1925).

101. State ex. rel. Adams v. Superior Court for Okanogan County, 356 P.2d 985 (Wash. 1960).

102. 25 U.S.C. $\$ 348$.

103. 25 U.S.C. $\$ 412 a$.

104. McClanahan v. Arizona, 411 U.S. 164 (1973).

105. 25 U.S.C. $\$ 398,398 \mathrm{c}, 401$.

106. British-American Oil Production Co. v. Board of Equalization of Montana, 299 U.S. 159, 164.(1936).

107. 25 U.S.C. $\$ 398$.

108. 25 U.S.C. $\$ 398 \mathrm{c}$.

109. M-36310 (10-13-55).

110. M-36345 (5-4-56).

111. 4 Ind. L. Reptr. H-7.

112. See Part T, Section I, supra, in the text to which note 14 et seq. is appended, for a discussion of the 1938 Act. For commentaries consistent with the solicitor's current view, see Israel, "The Reemergence of Tribal Nationalism," Institute on Indian Land Development, Part 13 (Rky. Mtn. Min. L. Div., 1976). See. also Santa Rita Oil and Gas Co. v. Bd. of Ed., 54 P.2d 117 (Mont. 1936), rev'd in part, 116 P.2d 1012 (Mont. 1941).

112a. Civ. Act. No. 77-292, 5 Ind. L. Reptr. F-24.

113. 30 Fed. Reg. 7520 (1965).

114. 532 F.2d 655 (1975), cert. denied, 45 U.S.L.W. 3463 (Jan. 10, 1977 ).

115. Norvell v. Sangre de Cristo Development Company, Inc., 372

F. Supp. 348 (D.C. N.M. 1974); Rincon Band of Mission Indians

v. County of San Diego, 342 F. Supp. 371 (S.D. Cal. 1971), rev'd on other grounds, 495 F.2d1 (9th Cr. 1974).

116. 25 U.S.C. \$465.

117. See an excellent analysis of the significance of section 1.4 in Chambers and Price, "Regulating Sovereignty: Secretarial Discretion and the Leasing of Indian Lands," 26 Stan. L. Rev. 1061, 1091, n. 128 (1974).

118. 36 Stat. 557; N.M. Const., Art. XXI, \$2.

119. See State Securities v. Anderson, 506 P.2d 786, 787 (N.M. 1973); Organized Village of Kake v. Egan, 369 U.S. 60, 67 (Alaska 1962); Williams v. Lee, 358 U.S. 217 (Ariz. 1959); Draper v. United States, 164 U.S. 240 (Mont. 1896). See also George de Verges, "Jurisdiction: 
Extension of State Authority over Indians Lands--The New Mexico Cases," 3 Am. Ind. L. Rev. 137 (1975).

120. 72 Stat. $3 \overline{39 .}$

121. 36 Stat. 557.

122. 26 Stat. 215.

123. 25 Stat. 676.

124. 36 Stat. 557.

125. 25 stat. 676.

126. Ibid.

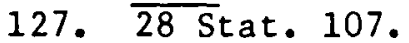

128. 25 Stat. 676.

129. 26 Stat. 222.

130. Felix v. Patrick, 145 U.S. 317, 332 (1892) (dictum); Adoption of Firecrow v. District Court, 536 P. 2d 190 (Mont. 1975). See also Department of the Interior, Federal. Indian Law (1966), p. 363.

131. Fisher v. District Court of Montana, 96 S. Ct. 943 (1976).

132. See Part I, Section IV, supra, on Federal Authority.

133. See note 43 supra.

134. See Section I D, supra.

135. See Felix v. Patrick, 145 U.S. 317, 332 (1892) (dictum); Adoption of Firecrow v. District Court, 536 P.2d 190 (Mont. 1975). See also Department of the Interior, Federal Indian Law (1966), p. 363.

136. See the text in Part I, supra, on Federal Authority to which note 343 et seq. is appended.

137. Schantz v. White Lighting; 502 F.2d 67 (1974), referring to 25 U.S.C. $\$ 1302(8)$.

138. See discussion in Part. III, infra, on Tribal Authority to which note 450 et seq. is appended.

139. See note 43, supra.

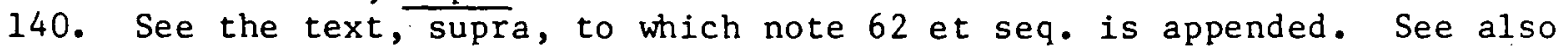

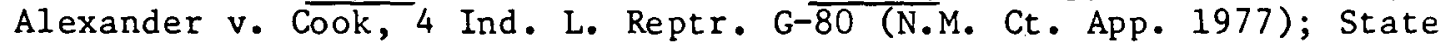
v. Atteberg, 519 P.2d 53 (Ariz. 1974).

141. See note 43, supra.

142. See the text, supra, to wich note 137 is appended.

143. Francisco v. State, 541 P.2d 955 (Ariz. Ct. App. 1975).

144. Old E1k v. District Court, 552 P.2d 1394 (N.M. 1976); State Securities, Inc. v. Anderson, 506 P.2d 786 (N.M. 1973); Natewa v. Natewa, 499 P.2d 691 (N.M. 1972).

145. Little Horn State Bank v. Stops, 3 Ind. L. Reptr. h-60 (Mont. 1976 ). 146. 116 U.S. 28 (1885), discussed, supra, in the text to which notes 7-8, 64 are appended.

147. See Harkness v. Hide, 98 U.S. 476 (1878); Annis v. Dewey County Bank, 335 F. Supp. 133 (D.C.S.D. 1971). See, however, the Arizona, New Mexico, and Montana cases cited, supra, at notes 143-145, for a contrary view.

148. See subsections $C$ and D, supra.

149. See Section II on Federal Environmental Laws in Part I on Federal Authority and Constraints, supra.

150. 59 Am. Jur. 2d, "Partnerships," $\$ 6-7$.

151. See Norvell v. Arizona Public Service Co., 510 P.2d 98 (1973); 39 Fed. Reg. 42513, amended in 40 Fed. Reg. 25004. See also Norvell v. Sangre 
de Cristo Dev. Co., 372 F. Supp. 348 (D.C. N.M. 1974), rev'd on other grounds, 519 F.2d 370 (10th Cir. 1975).

152. See notes 7-8, supra.

153. See notes $67, \overline{74-75}$, supra.

154. See notes 68-69, supra.

155. See 40 C.F.R. $\$ 52.21 ; 39$ Fed. Reg. 42513, 42515; 40 Fed. Reg. 25004. See also 3 Legislative Review, \#7, p. 5 (1975) (in-house memo of the administrator of the EPA).

156. Note 23 et seq., supra.

157. Note 31 supra.

158. See the text, supra, Part I on Federal Authority and Constraints dealing with leasing and operations on Indian lands.

159. See the discussion, supra, to which notes 68-69 are appended.

160. Shoshone and Arapahoe Tribes v. Oil and Gas Conservation Comm'n of Wyoming (Civil Action No. 5367); Assiniboine and Sioux Tribes v. Calvert Exploration Co., 223 F. Supp. 909 (D. Mont. 1963), rev'd on other grounds, 339 F.2d 360 ( 9 th Cir. 1964).

161. See the discussion, supra, subsections $C$ and $D$.

162. See the discussion, supra, subsection E.

163. See also Fort Mohave Tribe v. County of San Bernardino, Calif., 3 Ind. L. Reptr. e-61 (9th Cir. 1976), cert. denied, 45 U.S.L.W. 3705 (4-26-77).

164. See, e.g., Part I, Section I C(7), dealing with assignments of mineral leases and contracts.

165. See G.T.E. Gonzalez, "Indian Sovereignty and the Tribal Right to Charter a Municipality for Non-Indians: A New Perspective for Jurisdiction on Indian Land," 7 N.M. L. Rev. 153 (1977). A three-judge court concluded that such an "infringement" existed, because of overlapping tribal and State cigarette sales taxes in Confederated Tribes of the Colville Indian Reservation v. State of Washington, 5 Ind. L. Reptr. F-46 (E.D. Wash. 1978).

166. See G.T.E. Gonzalez, "Indian Sovereignty and the Tribal Right to Charter a Municipality for Non-Indians: A New Perspective for Jurisdiction on Indian Land," 7 N.M. L. Rev. 153 (1977). A threejudge court concluded that such an "infringement" existed, because of overlapping tribal and State cigarette sales taxes in Confederated Tribes of the Colville Indian Reservation v. State of Washington, 5 Ind. L. Reptr. F-46 (E.D. Wash. 1978).

167. See subsection $C$, supra, to which notes 44-50 are appended.

168. Ibid.

169. $\overline{\text { Ibid. }}$

170. - See the text, supra, to which note 53 et seq. is appended.

171. See Mescalero Apache Tribe v. Jones, 411 U.S. 145 (1973).

172. Eastern Navajo Industries, Inc. v. Bureau of Revenue of New Mexico, 552 P.2d 805 (1976).

173. See United States v. Sțate Tax Comm'n of Mississippi, 505 F.2d 633 (5th Cir. 1974)(dictum).

173a. See 25 U.S.C. $\$ 477$.

174. 25 C.F.R. $80.1(k)$.

175. See case cited in notes 45,172 , supra.

176. 59 Am. Jur. 2d, "Partnership," \$\$6-7.

177. See the text, supra, to which note 53 et seq. is appended. 
178. See the text, supra, to which note 105 et seq. is appended.

179. See the discussion in subsections $C$ and $D$.

180. Bryan v. Itasca Cty., Minn., 425 U.S. 373, 96 S. Ct. 2102 (1976).

181. See the discussion at subsection $E$, supra, to which note 62 et seq. is appended.

182. Moe v. Confederated Salish and Kootenai Tribes, 425 U.S. 463, 96 S.Ct. 1634 (1976). 183. Ibid.

184. Fort Mohave Tribe v. County of San Bernardino, Calif., 3 Ind. L. Reptr. e-61 (9th Cir. 1976), cert. denied, 45 U.S.L.W. 3705 (4-26-77). See however, Confederated Tribes of the Colville Indian Reservation v. State of Washington, 5 Ind. L. Reptr. F-46 (E.D. Wash. 1978).

185. Ibid.

186. See subsection $E$, supra, to which note 68 et seq. is appended.

187. See subsection E, supra.

188. See subsection $C$, supra.

189. Ibid.

190. See subsection E, supra.

191. Ibid.

192. See subsection $G(5)$, supra.

193. See subsection $E$, supra.

194. See subsection D, supra.

195. See subsections $D$ and E, supra.

196. See Part I, Section V B, supra. 
PART III

JICARILLA TRIBAL GOVERNMENTAL AUTHORITY OVER

MINERAL OPERATIONS

Section I. Tribal Control Over Development.

\section{A. General Principles.}

As governmental authorities with limited sovereignty, Indian tribes have the same power to regulate and tax as do other governmental entities. These powers of tribal government, like those of any other government, are subject to certain limits. The source of limits or constraints on tribal power are found in the Federal law, both legislative and regulatory, and in the tribal law, both constitutional and legislative. Not only does tribal governmental authority exist over tribal members and other Indians within the reservation, it also appears clear that authority involving civil matters extends over non-Indians and non-Indian activities within the bounds of the reservation. To the extent not contrained by Federal or tribal law, Indian tribes in their contracts with non-Indians may certainly provide for and obtain enforceable contractual rights to expect observance of agreed upon standards for mineral development and operations. It has, however, been decided by the U.S. Supreme Court recently that Indian tribal governments do not have criminal jurisdiction over non-Indians. Therefore, Indian tribes do not have the authority to imprison non-Indians for violations of tribal law. In addition, a tribe would not have civil jurisdiction over non-Indian activities occurring outside the boundaries of the reservation.

Section I discusses specifically the options available to the Jicarilla Apache Tribe for controlling oil and gas development with the various limits thereon and the problems of enforcement of these contractual or regulatory standards in the context of ongoing and future operations. Additionally, specific direction on implementation will be provided. Because of (1) the diverse nature of the problems that can arise, (2) the complexity of many of the problems which can arise, and (3) the ever-changing nature of the law, it is recommended that readers rely on this report only as a guideline and that the Tribe's attorneys be consulted when specific problems arise or when a particular action is proposed. 


\section{B. Control of Tribal Ordinance of $0 i 1$ and Gas Operations.}

(1) General Need for Tribal Regulation.

A decision by the jicarilla Tribe to regulate oil and gas operations requires a close analysis by a technically trained person of the substantive adequacy of the Federal regulations in titles 25 and 30 of the Code of Federal Regulations. Following this, the adequacy of the performance of the USGS and BIA in enforcing the regulations should be evaluated. If the Federal regulations are deemed adequate and if the Department of the Interior is not enforcing such regulations as it should, pursuant to its trust responsibilities, then the Tribe should decide whether to enforce such trust obligation in the courts. Alternatively, a decision could be made to assist Interior in the enforcement of the Federal regulations, perhaps by contract under the Indian Self-Determination and Education Assistance Act of $1975,1 /$ or by independently overseeing such enforcement with the aid of technically trained people. Important considerations in determining whether the Tribe should regulate on its own are (1) the extent and nature of tribal enforcement power and (2) the extent of the duty, if any, of Interior to enforce tribal regulation. These considerations are discussed below.

\section{(2) Tribal Authority Under the Current Federal Regulations Governing $0 i 1$ and Gas.}

(a) In General.

Under the current Federal regulatiuns, it would appear that a tribe may regulate those aspects of oil and gas activities covered by the regulations in title 25 C.F.R.2/ These regulations cover all matters except those involving operations on the premises. Included are such matters as Indian training and employment and the right to inspect the books and records of the operators. Under the current regulations, most operational matters, i.e., those matters covered in title 30 C.F.R., part 221 , would not appear subject to Indian regulation without the incorporation of such regulations as a part of the lease or contract made with the oil and gas operator. This limitation on the tribal power to regulate results from the fact that the Federal regulations governing operations appear to apply absolutely with no express allowance or exception made for tribal regulation. To the extent that the tribe is permitted to regulate, it very possibly must enforce its regulations on its own. $3 /$ The legal and practical difficulties surrounding tribal enforcement are discussed below in subsection $B(4)$.

Under the current Federal regulations a tribe may persuade the Secretary to impose restrictions on operations.4/ However, the Secretary is not bound to such regulations to do so. In addition the secretary has the power to waive the regulations of Department of the Interior. It is possible, therefore, if such a waiver of title $30 \mathrm{C} . \mathrm{F} . \mathrm{R}$. operation regulations is obtained, to open the door to tribal regulation of operations. However, the likelihood of obtaining such together with the problems of enforcement as outlined below render this possibility rather impractical. 


\section{(b) Existing Leases and Contracts.}

With regard to existing agreements, the Tribe could not impose regulations that change the duration of the operator's interest and the amount of compensation owed to the Tribe by the operator. However, in the current regulations, no right is given the Tribe to inspect operator's books and records. Additionally, no provision is made for Indian training and employment. If the difficulties with tribal enforcement, described below, are deemed surmountable, then the Tribe might well enact ordinances in accordance with the procedure prescribed in its constitution and described below in the subsection on implementation to cover these areas.

\section{(c) Future Agreements.}

Under the current regulations, limitations on tribal regulations apply also to future agreements. In accord with the subsection below on regulation by contract, if the Tribe makes the regulation a part of the contract, then as to most aspects, the contract including such regulations would be (or probably should be) enforced by the appropriate officials of the Department of the Interior.

(3) Tribal Authority to Regulate Under the Proposed Regulations Governing 0 il and Gas.

(a) In General.

The proposed regulations permit tribal law to supersede the regulations in title 25 C.F.R. if tribal law is at least as stringent as the latter regulations. However, again no allowance or provision is made for tribal law to supersede the operating regulations in title $30 \mathrm{C.F} . \mathrm{R} . \underline{5} /$ As a consequence, Jicarilla tribal regulation of those aspects of oil and gas operations covered by those regulations would not be valid. The conclusions drawn immediately above in subsection (2) dealing with probable need for and difficulties with tribal enforcement of its own regulations, as well as the comments on existing and future leases, also apply to the Tribe's authority to regulate under the proposed regulations. Under the latter, however, comments about the need for a tribal assertion by regulation of a right to inspect operator's books and records do not apply because of the expanded right to inspect given in the proposed regulations.

\section{(4) Enforcement of Valid Tribal Regulations.}

\section{(a) Department of the Interior.}

Neither the current nor proposed Federal regulations are clear as to whether Interior has an obligation to enforce valid tribal regulations. In both, the Secretary is provided the authority and responsibility to enforce the "applicable" regulations.6/ However, it appears likely that this secretarial authority and responsibility will be held to refer merely to the Federal regulations in titles 25 and 30 of the C.F.R. As a consequence, the Tribe probably must enforce its own regulations. 


\section{(b) Tribal Enforcement.}

The Tribe is quite restricted in the means available to it to enforce its regulations. First, State and Federal courts probably have no jurisdiction to enforce tribal law. Secondly, the recent U.S. Supreme Court decision of Oliphant $v$. Suquamish Indian Tribe indicates that tribal courts have no criminal jurisdiction over non-Indians.7/ In addition, the Jicarilla Tribal Constitution provides that the tribal court has jurisdiction in all civil matters where members of the Jicarilla Apache Tribe are defendants. $\underline{8} /$ Thus any attempt to enforce the laws of the tribal government in tribal court against non-Indians would be invalid.

\section{(c) Recommendations on Tribal Enforcement.}

(i) An attempt should be made to obtain agreement from Interior that it will enforce the tribal law pursuant to the current and proposed regulatory provisions which require the Secretary to enforce the "applicable" regulations as discussed above in subsections $B(2)(a)$ and $B(3)(a)$.

(ii) Another possible basis for limited tribal control which does not relate to tribal regulation but which should be mentioned at this point, derives from the contractual rights which the Tribe has as lessor or contracting party on its existing agreements and leases. In the BIA form oil and gas leases, the lessee agrees with lessor (the tribe) to abide by the governing Federal regulations. Such contractual promises are probably also contained in the several net profit or joint-venture agreements which are uulslaiding on tribal lands. liessor, the tribe, should be able therefore to enforce such promises in state court if Interior is not diligently enforcing them.

(iii) As discussed above in subsection $B(1)$, the Tribe might consider forcing Interior to fulfill its trust responsibility to enforce the Federal regulations by Federal court action. Alternatively, it might consider contracting with Interior under the Indian Self-Determination Act to take over some aspects of the enforcement responsibility.

(iv) The Tribe could seek to amend its constitution to vest in tribal court civil jurisdiction over non-Indians. The procedure for constitutional amendments is set forth in Article XXII thereof. With such an amendment, the Tribal Council could enact, pursuant to the procedure described in the constitution, whatever ordinances governing operators it feels necessary together with penalties for their violation within the limits described above. Additionally, it could create a position or an office that would have responsibility for the enforcement of these laws with the power to require conformance, to stop operations, and to impose penalties as set forth in the tribal ordinances. Assuming that the Tribe obtains a waiver of the Federal operational regulations in title 30 C.F.R, as discussed above in subsection $B(2)(a)$, it could adopt many aspects of the statutory scheme, of oil and gas regulation of any oil and gas producing state. $\underline{9} /$ The person in charge of this tribal office could be empowered to issue orders requiring immediate compliance or compliance 
within a prescribed time with the tribal law. These orders would give notice of the rule(s) violated. Failure to comply could by ordinance result in imposition of a money fine or perhaps even eviction from the reservation. As described below, due process requires the opportunity for a hearing which according to the tribal constitution must occur in tribal court.

\section{(5) Implementation of Tribal Law.}

\section{(a) Tribal Constitutional Constraints.}

For recommendation (c)(iv) immediately above, a constitutional amendment is required in order to vest tribal court with jurisdiction over non-Indians. The procedure for such amendments is described in the constitution. The tribal constitution does appear to vest the Tribal Council with the authority to impose regulations on all aspects of oil and gas operations conducted by both Indians and non-Indians on the Jicarilla Reservation.

(b) Valid Regulation by Tribal Council.

\section{(i) Tribal Constitutional Requirements.}

The tribal constitution requires the following for valid legislative action by the tribal council: (1) such action must occur at a regular meeting or a validly convened special meeting of the council; (2) the council meeting must satisfy the quorum requirements; (3) such action must take the form of an ordinance rather than a resolution; (4) the ordinance must be passed by a majority of the council members present and voting; (5) the ordinance must be approved by the president of the tribe within the constitutionally prescribed time limits; (6) the president has veto power which may be overridden by the affirmative vote of a full three-fourths of the Tribal Council membership; and (7) to be binding, the ordinance governing the above described matters probably must be approved by the Secretary of the Interior.

\section{(ii) Indian Civil Rights Act Requirements.}

If the tribal council does not comply with this constitutional procedure, the ordinance may be held invalid by tribal court under the due process requirements of the Indian Civil Rights Act of 1968. Because of the recent U.S. Supreme Court decision of Santa Clara Pueblo v. Martinez 9a/ tribal court is the only forum for review of claimed civil abridgments under the ICRA. In addition the ordinance should be prospective only in its application to operations although it can be made to apply to existing as well as future agreements; it should be as clearly stated as possible to avoid the due process vagueness challenge; and it should prescribe the penalities or sanctions--such as cessation of operation orders and fines-which this tribal agency or court can apply and the circumstances for each. In addition, if an official is to be given the power to enforce such law, then the due process clause in the ICRA probably requires provision for such officials to give notice of the violation, the opportunity to be heard, i.e., to present evidence, to rebut adverse evidence, and the 
opportunity to appear with counsel, and to have the decision based only on the evidence. It would appear that due process does not require that an appeal procedure be provided. The due process requirements probably would be satisfied if the provisions for a hearing were modeled after the Federal procedure for hearings set forth in the regulations. Nevertheless, all should be provided for in the ordinance. Since limited exceptions can be made in certain cases, e.g., emergency actions, and in view of the complexity of the above requirements as applied to the specific case, it is strongly recommended that in order to avoid a legal challenge, the Pueblo should consult its counsel for help in preparing any ordinances of the kinds discussed above.

\section{(iii) Legislative Formal Requirements.}

As long as the tribal constitutional requirements are met, there do not appear to be any legal requirements for the form of the ordinance. Elements such as the following are helpful either in salvaging the balance of a statute if portions are successfully challenged or in enhancing the formal appearance or intelligibility of the statute: (a) severability clause to express the legislative intent to preserve the balance of the statute intact if any part is found by a court to be invalid; (b) purpose clause, to aid in conveying the meaning of the statute to the legislators involved and later to the courts which must construe it; (c) title, which gives the statute some public identity; (d) headnotes, which capsulize the substance of each section.

C. Control by Contract of $0 i 1$ and Gas Operations.

\section{(1) In General.}

If the Tribe obtains a promise of an operator in a contract to abide by tribal law governing mineral development, then such promise will be enforceable in State court. In general, an agreement by a lessee or operator. to abide by tribal law and the decisions of tribal of ficials regarding the applicability of such law to particular activities is subject to two alternative rules. First, if the particular law sought to be enforced is in addition to the requirements of the current Federal regulations and not inconsistent with them, then such promise will be enforceable without further requirements. If on the other hand tribal law to be incorporated into the contract is inconsistent with the current Federal regulations, then, in order to be enforceable, the Federal regulation(s) in question must be waived in accordance with the requirements set forth in Part I, Section I C(1) of this study. To avoid troublesome challenges, it is best to obtain a blanket waiver of the Federal regulations insofar as they are to be supplanted by the agreed to requirements of tribal law. (See Part I, Section I C(11)). Under the proposed regulations, the USGS operating regulations may be superseded by the agreement so that no waiver would be necessary for agreements effective after the date that these regulations are finalized. (See Part I, Section I $D(6)(a)$. ) 


\section{(2) Enforcement.}

Tribal law governing operations by which the lessee or operator has agreed to abide is enforceable by the appropriate Interior officials under Federal regulations, both current and proposed. In addition it would seem that the tribe has the additional right then to enforce the agreed to law in State court on a contract law basis.

\section{(3) Problems.}

Clearly, however, this avenue of enforcement of tribal law, i.e., under contract law in State courts by the tribe, is less desirable than enforcement by the Department of the Interior as the administrative regulator and trustee. This avenue is considerably less responsive in the sense that each attempt to enforce the contract would involve a law suit filed and prosecuted in State court with the consequent expense and time delays. Rather, if such tribal law has become a part of the contract, Interior officials should enforce it since under the current and proposed regulations as well as pursuant to their trust responsibility they are probably required to enforce the contracts which have been approved by the Secretary. The option in the tribes to go into state court can serve as a last resort which provides additional incentive to the operators to abide by their contracts.

Although it would appear that Interior is required to enforce the contracts as ayreed to, including any incorporated tribal law governing operations, the comprehensive proposed regulations of April 5, 1977, and an ad hoc proposed amendment to the current regulations of July 19, 1977, would have the effect of relieving Interior of responsibility for enforcement of the regulations relating to royalties and their proper payment if the production return to the Tribe is in a form other than percentage royalties, e.g., a profit-sharing arrangement. (See Part I, Section I $C(5)(f)$ and $D(6)(c)$.

Section II. Tribal Taxation.

\section{A. In General.}

Until recently, the limited case law and the opinion of scholars on a tribe's right to tax indicated that tribal governments certainly had the power to tax mineral production from Indian lands, whether accruing to non-Indians or Indians. The power to tax was thought to derive from the limited sovereignty of the tribe as a governmental authority just as the tribal power to regulate has been justified. This general power to tax would include all the types of taxes that governments presently levy, including income, sales, franchise, gross receipts, property, and particularly severance taxes.

However, on 12-29-77 the Federal District Court for the District of New Mexico concluded in Merrion v. Jicarilla Apache Tribe $9 \mathrm{~b} /$ that a tribal severance tax imposed on the oil and gas production of non-Indian operators was invalid. The holding of the Court was based on the following: 
(1) Congress intended to grant exclusive authority to the States to tax oil and gas production from executive order Indian reservations.

(2) In the IRA, Congress indended that, a tribe accepting a charter (and probably even merely a constitution), as the Jicarilla have done, only has the powers enumerated in the IRA and those under existing law. Neither source specifically empowers the Jicarilla Tribe to tax non-Indians.

(3) The Jicarilla tax, applying only to production taken of $f$ the reservation, discriminated against interstate commerce.

(4) The tax, when aggregated with the federally authorized State tax, is an unlawful burden on interstate commerce.

The first basis described above as well as the second are contrary to a settled principle applied as late as 1978 in the U.S. Supreme Court case of Santa Clara Pueblo v. Martinez, $9 \mathrm{c} /$ that Federal intrusions on tribal sovereignty should be explicit. There's nothing implicit, let alone explicit, in either statute which would bar a tribal tax. The IRA was not designed to deprive tribes of authority but rather to consolidate and organize them. It would appear that Indian tribes have long been accepted as having taxing power over non-Indians and the reservation as a part of their limited sovereign authority.

The third and fourth bases for the holding lack merit for several reasons. First, since the Jicarilla tax is levied against production exported from the reservation, not that exported from New Mexico, the tax does not discriminate against interstate commerce but rather merely against extra-reservation commerce. This is not barred by the U.S. Constitution. As for the "burden" argument, property is only immune from tax when it is in transit in interstate commerce. The Jicarilla tax was imposed at, the point of severence. Also, there is nothing invalid in two different political units taxing the same property in the same year. As for the argument of excessiveness of the two taxes, the Montana coal severance tax is higher than the combined Jicarilla/New Mexico tax, but it has not been. ruled an undue burden on commerce. Additionally, the more fundamental question exists of whether Indian tribes are bound by the limits of the commerce cluase, which constains State and local government.

If the case is affirmed by the Tenth Circuit, a tax by an IRA tribe on non-Indians is probably invalid. If the only point upheld is the discrimination argument, then the tax ordinance can be amended to apply uniformly.

Pending reversal, Indian tribes in the State of New Mexico do not have the power to impose mineral production taxes for production accruing from "bought and paid for" and executive order lands. (See Part II, Section I 
$G(6)(a)$.$) In addition, IRA tribes such as the Jicarilla probably have no$ power to tax non-Indians in any manner according to the reasoning in this case.

\section{B. Limitations on the Tribal Power to Tax.}

Assuming a reversal of the New Mexico Federal district court case, the following are other limitations which may affect the validity of a particular tax imposed by the Jicarilla Tribe.

(1) Indian Civil Rights Act of 1968.

As discussed above in Part I, Section III B, a very difficult and as yet unresolved question is the power of the Tribe to impose different rates of tax on Indians and non-Indians, or to tax only non-Indians, or to tax only non-Indians with regard to particular activities. To be safe from attack under the equal protection requirements of the ICRA, the tax should not differentiate between Indians and non-Indians.

Successful challenge to the legality of such differential taxation could be avoided on the ground that the tax is for the privilege of operating on tribal property and the Indian exemption encourages Indian involvement and investment and thus a consolidation of the tribal economic base. In any event, it would appear that tribal court is the only forum available for the challenge of civil tribal actions under the ICRA.10/

\section{(2) Tribal Constitution.}

The tribal constitution confirms the authority of the Tribe to tax non-tribal members if the tax is approved by the Secretary of the Interior. Also the tax must be enacted in accordance with the procedural requirements prescribed in the tribal constitution and described above in subsection I $B(5)(b)(i)$.

\section{(3) Limiting Contracts.}

If the Tribe has agreed in any of its contracts outstanding to limit or refrain from taxing the other contracting party, such agreement will probably be binding and therefore upheld by the courts. Despite a general rule that a governmental body cannot contract away its governmental powers, there is a body of law indicating that a contract agreement limiting a. government's taxing power is an exception.

\section{(4) Jurisdictional.}

The power of the Tribe to tax generally extends to activities, property, and person, i.e., whatever is the subject matter of the tax and whether Indian or non-Indian. However, due process and the tribal constitution authorize those powers of the Tribe only inside the reservation boundary. 
Section III. Tribal Business Organization.

A. In General.

The Jicarilla Tribe and Indian tribes in general may engage in and conduct business as they wish except as limited by Federal law and their own legal requirements. The source of Federal constraints arise, out of the Indian Trade and Intercourse Acts which limit the tribe's power to convey interests in land, to enter into contracts involving their lands, and to employ attorneys. These constraints are analyzed in Part I, Section I A. In addition, the tribes are constrained in the use of other funds and other property held in a trust capacity by the Federal government.

B. Tribal Legal Power and Constraints to Conduct Business.

(1) In General.

The tribal constitution empowers the Tribal Council to transfer tribal assets to various business organizations as vehicles for the conducting of business. It would appear:

(a) That such organizations must be wholly tribally owned if trust properties are to be transferred to it by any means other than those outlined above in Part $I$ in the Federal leasing acts and other Federal laws permitting transfers of tribal property;

(b) That the Tribal Council must prescribe in detail the powers and controls of this transferee organlzation. However, the Tribe has complete flexibility in the type of organization created;

(c) That the approval of the Secretary of the Interior is required for the transfer of property to such organizations.

The constitution requires adequate accounting of all tribal financial transactions including a comprehensive annual audit and bonding for employees responsible for tribal funds. In addition, the Tribal council is empowered to borrow money for business and development purposes. If such loan is obtained from non-Federal sources, then the Secretary must approve the terms of the loan.

\section{(2) Tribal Business Organizations.}

If only the Tribe is to be involved, then a corporation may be created under State law, the IRA federally chartered corporation may be used, or the Tribe may operate as a sole proprietor. The above requirements and limits appear to be the only ones applicable to such business organizations.

\section{(3) Participants in Addition to the Tribe Involved.}

If a participant in addition to the Tribe is involved, then either a partnership or a corporation may be used. Such participants may be Indian individuals or non-Indians. However, when there are such additional participants, then the two acts dealing with tribal lands probably must be 
complied with if such business is to be involved with tribal lands and minerals, i.e., the $1938 \mathrm{Tribal}$ Leasing Act and the act requiring approval for contracts relating to tribal lands. These Acts are discussed above in Part I, Section A. Of course, the. IRA-chartered corporation may not be used with individual Indian or non-Indian participants since such corporation is by statute wholly owned by the Tribe. In addition the requirements mentioned in subsection (1), above, also appear to apply if the Tribe is to participate actively and not just as an investor in the conduct of the business.

\section{Comparisons of Business Organizations.}

\section{(1) In General.}

The following tribal business organizations with and without other participants will be discussed from the point of view of State tax law, State regulations, Federal income tax law, and sovereign immunity and limited liability:
(a) IRA corporation,
(b) State corporation,
(c) State partnership,
(d) State limited partnership,
(e) tribally chartered corporation and partnership, and
(f) sole proprietorship.

See Part II, subsections I G(4-7), for a detailed analysis of these matters.

\section{(a) IRA Corporation.}

Such corporations created by election of IRA tribes pursuant to that Act exist primarily because Congress wanted to provide a vehicle for the tribes to conduct business affairs. The Jicarilla Tribe elected to obtain such a charter which was ratified on June 16, 1960. See the discussion in Section II A of this part.

\section{(i) State Tax Laws.}

The only State tax laws that could possibly apply are the mineral production taxes pursuant to Federal statute. (See Part II, Section I $G(6)(a)$.) A recent appeals decision of the Federal District Court of New Mexico holds that the State has such taxing power over mineral production. 


\section{(ii) State Regulation.}

The IRA corporation should be completely immune to state regulation. (See Part II, subsections I G(1-4).)

\section{(iii) Federal Income Tax Laws.}

It is likely that an IRA corporation would be exempt from Federal income tax just as Indian tribes themselves are exempt. Such should be so because the IRA corporation is a federally established alter ego for a tribe. Nevertheless, it would be wise to obtain a revenue ruling on the question before proceeding if a Federal income tax exemption is critical. See Part I, subsection $V B$.

(iv) Sovereign Immunity and Limited Liability.

The IRA corporation should have the same sovereign immunity as the Tribe, except to the extent that it is expressly waived. The charter for the Jicarilla IRA corporation provides that only assets specifically pledged or assigned are vulnerable to suit. Otherwise, complete sovereign immunity is retained.

\section{(b) State Corporation.}

(i) State Tax Laws.

State mineral production taxes may be levied, according to a recent case out of the Federal District court of New Mexico which is on appeal. However, the State court of appeals has held that a corporation owned 51 percent or more by Indians and qualifying as an Indian enterprise under Federal law is immune from State taxes other than mineral production taxes. However, State corporations owned less than 51 percent by Indians are probably subject to State taxes. (See Part II, subsections I G (6-7.)

\section{(ii) State Regulation.}

As long as the New Mexico Court of Appeals decision stands, the State should not have the power to regulate corporations owned 51 percent or more by Indians. However, corporations with less than that percentage of Indian ownership are probably subject to State regulation.. There, is yet no definite answer to this question. (See Part II, subsections I G $(5,7)$.)

\section{(iii) Federal Income Tax.}

It is quite possible that a state corporation, even completely tribally owned, is subject to Federal income taxes because of its status as a separate entity. Nevertheless, there is no authority on the question. See Part I, Section V B. If such exemption is critical, the tribe should apply for a revenue ruling on the issue.

\section{(iv) Sovereign Immunity and-Limited Liability.}

It is unlikely that the principle of sovereign immunity would apply to protect the corporate assets even if 100 percent tribally owned. However, 
the limited liability of any corporation incorporated under State law would render corporate assets vulnerable to suit, but would protect the other assets of the Tribe which are not in the corporation.

\section{(c) State Partnership.}

(i) State Tax Laws.

In view of the fact that for most purposes a partnership is not a separate entity, it is likely that the property, activities, and income owned at least partially by Indians would not be taxable by the State except to the extent of (1) its mineral production and (2) the income accruing to non-Indians. If the partnership is owned 51 percent or more by Indians, a stronger case for the above exists in New Mexico because of state court of appeals decison described above. (See Part II, subsections I G(5-7).)

\section{(ii) State Regulations.}

The State should have no authority to regulate at least partially Indian-owned partnership activities and property because, again, it is not for most purposes a separate entity. This conclusion is more secure if the partnership is owned 51 percent or more by Indians. (See Part II, subsections I $G(2-5,7)$.)

\section{(iii) Federal Income Tax.}

Although there is no basis for certainty in this context, it is likely that the partnership income attributable to the Tribe is tax-free and the partnernship income attributable to others is taxable.

\section{(iv) Sovereign Immunity and Limited Liability.}

It is most likely that partnership assets would be vulnerable to partnership liabilities. In addition the assets of all general partners other than the Tribe would, under normal partnership law, be vulnerable to partnership liabilities. However, assets of the Tribe, other than those contributed to the partnership, should be immune from suit under the sovereign immunity principle. Additionally, outside assets of limited partners would be immune from suit under general partnership law.

\section{(d) State Limited Partnership.}

If the Tribe is to join with another to conduct business, then the State limited partnership is a possibility. If the Tribe is the only general partner then, the matter from the Tribe's point of view should be identical to the sole proprietorship (point (f), below). If there are other general partners in addition to the Tribe, then the conclusions applicable to State partnerships, described above, should apply. It the Tribe is to be a limited partner, then as to the Tribe's interests the organization would probably be treated like a State corporation (point (b), above). 


\section{(e) Tribal Corporations and Partnerships.}

Tribal law makes no provision for the creation of these organizations. As a result before this alternative could be viable, the Tribal Council would have to enact ordinances permitting their creation presumably modeled to a great extent after State law. The advantage of this would lie in the context of reducing further the basis for any State authority to tax or regulate except to the extent of mineral production taxes. The other questions, i.e., Federal income tax and sovereign immunity, would be resolved identically to those involving State corporations and partnerships.

\section{(f) Sole Proprietorship.}

A sole proprietorship conducted on the reservation by the Tribe should have the benefit of complete immunity from State regulation and taxation except to the extent of mineral production taxes. Additionally, it should be free from Federal income tax and it should be immune from suit under the sovereign immunity principle.

\section{(2) Summary.}

All considered, the IRA corporation appears to be the best avenue for the Tribe to conduct business separately from government. From a practical standpoint it has already been created, it is known to Interior officials, and the institution of federally chartered IRA tribal corporations was established by Congress specifically for the purpose of conducting tribal business. In terms of state taxation and regulation, it should clearly be immune except for State mineral production taxes. 'The latter, of course, appear unavoidable under any circumstances until the Federal case law is reversed. There is some uncertainty as to whether the Federal income tax would apply; but as explained above it is unlikely. Nevertheless, a revenue ruling should be obtained before proceeding in this form rather than as a sole proprietorship. Additionally, the principle of sovereign immunity should apply to protect the corporate assets except as expressly waived in the charter. The State corporation achieves part of these benefits but not to the same extent. The tribal corporation is not possible without a change in tribal law. The sole proprietorship is a viable alternative. It provides even more security than the IRA corporation on the Federal income tax question. Nevertheless, it may be desirable for the Tribe, from a policy point of view, to separate 1ts business activities from its governmental functions.

If Individuals, Indian and/or non-Indian, are also to be involved, then the business arm of the Tribe, whether the IRA corporation or the tribal government, could join in a State partnership with such other(s). The partnership, if owned 51 percent or more by Indian interests, is probably immune, as is the similarly situated State corporation, from State regulation and taxation except, of course, for mineral production taxes. Additionally, the partnership not constituting a separate legal entity has an advantage over the corporation on the question of the inapplicability of State law, if the New Mexico decision is reversed or if there is some but less than 51 percent Indian ownership. If a limited partnership form is 
used with the Tribe constituting a limited partner, then there is an increase in likelihood that State law would apply to those business activities as noted above.

\section{Indian Water Rights.}

\section{(1) General Right to Water.}

Indian water rights are based on two alternative theories: One is that the United States reserved water for the needs of the Indians. The other is that the tribes reserved the water when they ceded their lands to the Unites States.11/ Under either theory, the fundamental and as yet unresolved question is the extent of the tribal right. The U.S. Supreme Court case of Arizona v. California $12 /$ held with the agreement of the United States as the representative of the Indians that the Indian rights were measured by the amount needed for all of the irrigable acreage on the reservation. However, that case is not necessarily precedent on the appropriate measure for other river basins. The earlier U.S. Supreme Court case of Winters $v$. United States $13 /$ clearly leaves open the question as to whether the tribes are also entitled to amounts necessary for other future purposes such as mineral extraction and processing. Two early Ninth Circuit cases confirm the existence of this question left unanswered in Winters.14/ Nevertheless, it appears to make no difference to the extent of the water rights whether the tribe's source of title to reservation lands was executive order, treaty, or statute.15/

One can anticipate in the near future an increase in litigation in State courts to quantify water rights. The U.S. Supreme Court in Colorado River Water Conservancy District v. United States $16 /$ held that by Federal statute, i.e., the McCarren Amendment, 17/ State courts have concurrent jurisdiction with Federal courts to determine the specific rights of users, including Indians, in river systems.18/

\section{(2) Groundwater Rights.}

Very little can be said with any certainty concerning the nature and extent of the Tribe's right to groundwater. To the specified extent of the Tribe's water rights, groundwater which is recharged by surface waters traversing the reservation and groundwater reservoirs which extend beyond the boundaries of the reservation are probably subject to the Winters reserve right doctrine.19/ However, it appears reasonably arguable that groundwater aquifers, other than those above, would be wholly Indian owned and supplemental to the water to which the Tribe is entitled by its reserve right.20/ If the Tribe and/or non-Indians are making a substantial Investment which is dependent on groundwater, it may be prudent to obtain both tribal and State permits if there is any question about the particular water needed. Such investors might thereby avoid disputes with extra-reservation users whose permits would then have a lower priority. 


\section{(3) Transfers to Mineral Operator.}

Accompanying traisfers of leasehold or operating rights to tribal minerals by implication or express transfer is the right to sufficient water to conduct the mineral operation.21/ This right by implication or expression in the instrument creating the mineral right under State law applicable to private transactions can involve substantial quantities of water if, for example, a water flood operation is implemented for an oil reservoir.22/ For future leases, consideration should be given to limiting the oil operator to those groundwater supplies which are uneconomic for other surface uses. In addition, consideration should be given to charging for water used.

For activities other than production of oil and gas or other minerals, e.g., processing and manufacturing, it is unlikely that conveyances of limited rights to surface lands carry with them by implication rights to water. As a consequence separate conveyances of water must be made if water is necessary to such activity. The Federal statutory limits on conveyances of interests in land would appear to be applicable to these transfers. See Part I, Sections I A and B.

(4) Federal Environmental Law Applicable to Indian Water.

(a) The Federal Water Pollution Control Act (FWPCA).23/

The FWPCA applying expressly to Indian lands creates programs to limit discharges at the sources. Although its primary emphasis is on navigable streams, the Act creates difficulties for the ofl and gas operator who seeks to repressure an oil reservoir by water flooding. "Pollutant" is defined in the Act to exclude water, gas, or other material which is injected into a well to facilitate production of oil or gas if the well is approved by authority of the State in which the well is located.24/ In addition, the EPA is apparently of the opinion that, in the absence of an approved State permit program containing authority to regulate well injections, the Federal agency is itself without power to do so under the 1972 amendments.25/ Since the States certainly have no regulatory power over tribal operations, and probably none over non-Indian operations,26/ difficulties may exist for operators, Indian and non-Indian, in obtaining permission to conduct secondary recovery operations under the Act. However, reservations are considered to be municipalities for planning purposes under the Act and thus may be able to provide their own permit system under EPA supervision.27/ See Part I, Section II C.

\section{(b) The Safe Drinking Water Act.28/}

The Safe Drinking Water Act affects projects that may contaminate aquifer recharge zones and controls underground injections that may contaminate drinking water supplies. Repressurization for secondary recovery and the discharge of salt water from holding basins, as well as other ofl and gas operations, could be affected. Standards for drinking water initially are set by the EPA.29/ If a State does not have jurisdiction or its jurisdiction is in question concerning Indian lands, EPA will administer the regulations thereon.30/ EPA's proposed regulations suggest that an injection endangers drinking water sources if it is or will become necessary to increase treatments to make the water safe or it makes the water unfit for human consumption. See Part I, Section II G.

$$
\text { A-III-16 }
$$


FOOTNOTES

APPENDIX A, PART III

1. 25 U.S.C. $\$ 450$ et seg.

2. 25 C.F.R. $\$ 171 . \overline{29}$.

3. 25 C.F.R. $\$ 171.27$ provides that the Secretary may take steps to cancel a lease if "the lessee has violated any of the terms and conditions of the lease or of the applicable [emphasis added] regulations, . . ." It might be argued that valid Indian regulations could be considered "applicable" regulations. However, probably the word "applicable" refers to the title 25 or title 30 , C.F.R. regulations.

4. 25 C.F.R. $\$ 171.21(a)$.

5. Proposed 25 C.F.R. $\$ 182.3$ provides that the 30 C.F.R. $\$ 221$ operating regulations apply to the extent not inconsistent with the proposed title 25 regulations. It might be argued that since the proposed title 25 regulations permit more stringent Indian regulation to govern, the title 30 regulations may al so be so superseded. However, normal rules of construction do not require this conclusion and the proposed title 25 regulations at 182.1 (d) otherwise clearly state that more stringent tribal regulation only supersedes part 182 proposed regulations in title 25 .

6. 25 C.F.R. \$171.27; proposed 25 C.F.R. \$182.23(b).

7. 46 U.S.L.W. $4210(1978)$.

8. Art. XXIII, $\$ 1$ of the Jicarilla Constitution adopted 12-23-68 and approved 2-13-69.

9. As discussed above, however, tribal regulation independent of contract is probably not valid to the extent that the title $30 \mathrm{C.F} . \mathrm{R}$. regulations apply.

9a. 98 S.Ct. 1670 (1978).

9b. Civ. Act No. $77-292,5$ Ind. L. Reptr. F-24.

9c. 98 S.Ct. 1670 (1978).

10. Santa Clara Pueblo v. Martinez, 98 S.Ct. 1670 (1978).

11. See Winters v. United States, 207 U.S. 564 (1908).

12. 373 U.S. 546 (1963).

13. Note 11 , supra.

14. United States v. Ahtanum Irrigation District, 236 F.2d 321 (9th Cir. 1946); Conrad Inv. Co. v. United States, 161 F.2d 839 (8th Cir. 1908).

15. Winters v. United States, supra, note 11 ; Arizona v. California, supra, note 12; United States v. Walker River Irrigation District, 104 F.2d 334 ( 9 th Cir. 1939). 
16. 96 S. Ct. $1236(1976)$.

17. 43 U.S.C. $\$ 666$.

18. See also State ex rel. Reynolds v. Lewis, 545 P.2d 1014 (N.M. 1976).

19. Cappaert v. United States, 425 U.S. 128 (1976); United States v. Bel Bay Community and Water Association et al., 5 Ind. L. Reptr. F-43 W.D. Wash. (1978).

20. The Bel Bay case, note 19, supra, appears to conclude that all groundwater is subject to the reserved right doctrine. The facts as recited, however, in the Indian Law Reporter do not indicate whether the aquifer was completely overlain by reservation lands. In addition the question in the text, supra, was not at issue in the case.

21. See Tweedy :v. Texas Co., 286 F. Supp. 383 (D.C. Mont. 1968).

22. See Sun Oil v. Whitaker, 483 S.W.2d 808 (Tex. 1972).

23. See Part I, Section II.

24. 33 U.S.C. $\$ 1362(6)$.

25. W.H. Rodgers, Jr., Environmental Law (West, 1977), p. 372, citing Op. No. 590 (1974) of the Acting Deputy General Counsel.

26. See Part II, Section I G(.3).

27. 33 U.S.C. \$1362(6).

28. 42 U.S.C. $\$ 300 \mathrm{f}$ et seg.

29. 40 C.F.R. Part 141 .

30. 40 C.F.R. $\$ 142.3(\mathrm{~b})(2)$. This regulatory exclusion of state jurisdiction should apply to the Jicarilla Tribe. 